DOI: $10.36240 /$ etf-280

VÁROSFEJLŐDÉS A KÖZÉPKORI MÁRAMAROSBAN 
ERDÉLYI TUDOMÁNYOS FÜZETEK

280

ISSN 2068-309X 
ERDÉLYI TUDOMÁNYOS FÜZETEK

280

GULYÁS LÁSZLÓ SZABOLCS

\section{VÁROSFEJLŐDÉS A KÖZÉPKORI MÁRAMAROSBAN}

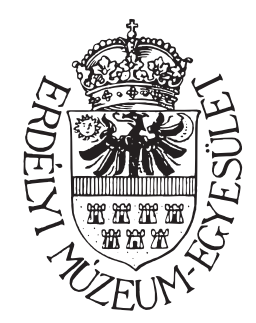

Kolozsvár, 2014 
A kötet megjelenését a Nemzeti Kulturális Alap, Communitas Alapítvány, Bethlen Gábor Alap és a Magyar Tudományos Akadémia támogatta.
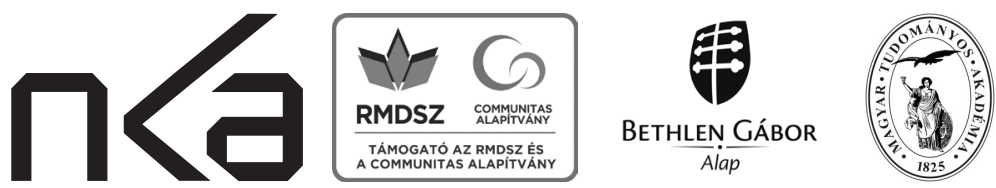

A kötet elkészítése idején a szerző a Bolyai János kutatási ösztöndíj támogatásában részesült.

(C) Gulyás László Szabolcs, 2014

(C) Erdélyi Múzeum-Egyesület, 2014

Felelős kiadó

BIRÓ ANNAMÁRIA

Lektorálta

GLÜCK LÁSZLÓ

\section{Korrektúra}

ANDRÁS ZSELYKE

A mellékelt térképet szerkesztette

SZILÁGYI ZSOLT

Mứszaki szerkesztés, borítóterv BODÓ ZALÁN

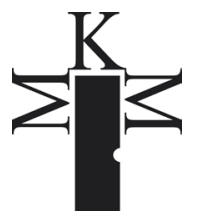

Készült az Erdélyi Református Egyházkerület Misztótfalusi Kis Miklós Sajtóközpontjának nyomdájában

Felelős vezető

DÁVID ZOLTÁN

Descrierea CIP a Bibliotecii Naţionale a României

GULYÁS, LÁSZLÓ SZABOLCS

Városfejlődés a középkori Máramarosban / Gulyás László Szabolcs.

- Cluj-Napoca : Societatea Muzeului Ardelean, 2014

Bibliogr.

ISBN 978-606-739-003-2

911.2(498.41) 


\section{TARTALOM}

1. A máramarosi „,koronavárosok” középkora a történeti szakirodalomban

2. A máramarosi mezővárosok történetének vázlata a megtelepedéstől a középkor végéig ...................................................................................... 19

3. A kollektív privilégium és a városok további kiváltságai........................29

A szőllősi és a máramarosi kiváltságlevél kapcsolata .............................29

A kiváltságlevelek megújításai és a kiváltságok kibővítései ................39

4. Magyarok, németek, románok és ruténok .................................................4 47

A máramarosi német hospesek .................................................................4 47

A vlahok beköltözése és birtokaik ............................................................49

A városok és a románság .......................................................................53

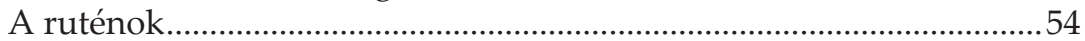

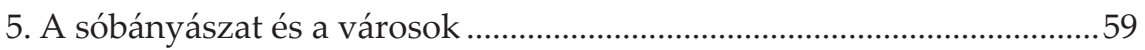

A máramarosi sóbányászat és a sókamarák ……………………….......59

A sóbányák személyi állománya............................................................68

A sójáradék mint az uralkodói kegy gyakorlásának eszköze ...............72

6. A máramarosi mezővárosok jogi viszonyai: önkormányzat és

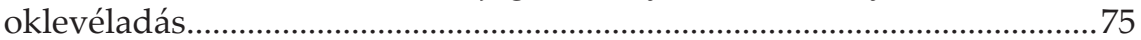

Az oklevelekben használt terminológia: villa - oppidum - civitas ....75

A mezővárosi tanács és az oklevéladás .....................................................76

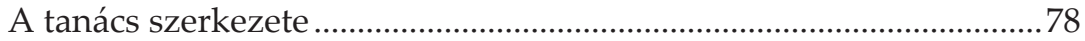

A magisztrátus illetékessége és feladatkörei...........................................82

A kora újkori statútumok rendelkezései és a középkori

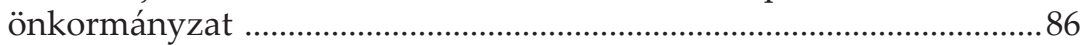

7. A mezővárosok lakóinak társadalmi-gazdasági helyzete........................89

8. A koronavárosokon innen és túl: Úrmező a középkorban ........................103

9. Epilógus helyett: a városfejlesztő tényezők (hiánya?) ..............................107 
Függelékek 113

1. A máramarosi mezővárosokra alkalmazott terminológiahasználat.. 113

2. Az ismert középkori máramarosi polgárok listája és legfontosabb adataik.

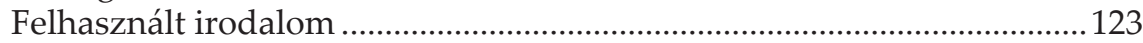

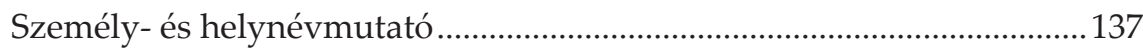

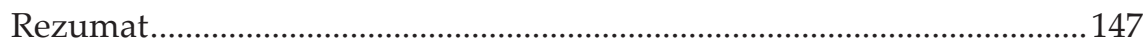

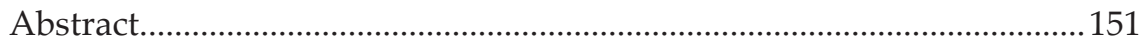




\section{A MÁRAMAROSI „KORONAVÁROSOK” KÖZÉPKORA A TÖRTÉNETI SZAKIRODALOMBAN}

A máramarosi „koronavárosok” ${ }^{11}$ a középkori magyar városhálózat karakteres csoportját alkották. Középkortól datálható királyi mezőváros létük önmagában még egyáltalán nem tekinthető speciálisnak, hiszen ha nem is tömegével, de mindenképpen tucatjával találhatunk még ezen kívül is királyi birtokban lévő oppidumokat a 15-16. századi Magyar Királyságban. ${ }^{2}$

A máramarosi mezővárosok igazi különlegessége valójában abban állt, hogy a huszti uradalom és a hozzá tartozó öt máramarosi koronaváros: Huszt, Visk, Técső, Hosszúmező és Sziget a sóbányákkal együtt az 1514. évi dekrétum 3. cikkelye alapján ${ }^{3}$ - egyébként közismert módon - az elidegeníthetetlen királyi birtokok közé tartozott. Ezzel olyan illusztris társaságba kerültek, amelyben a nyolc szabad királyi város (Buda, Pozsony, Sopron, Nagyszombat, Kassa, Bártfa, Eperjes és Pest) és a hét alsó-magyarországi bányaváros mellett még néhány további fontos civitas (így például Esztergom, Székesfehérvár, Kolozsvár, vagy éppen Szeged) is benne volt. Azaz a máramarosi mezővárosokat - az elidegeníthetetlen királyi birtok mivoltjukból következően - a középkori magyar városfejlődés élvonalával helyezte a törvény egy csoportba, még ha ez nem is jelenti azt, hogy jogi

${ }^{1}$ A „,koronaváros” mint önálló, csak Máramarosra jellemző településtípus soha nem létezett, amint erre Glück László is felhívta a figyelmet. A szó elterjedése is kifejezetten kései volt. Glück 2013. 9., főleg 2. jegyzet. Használatát vele ellentétben nem tartom feltétlenül kerülendőnek, hiszen egy, a közbeszédben rögzült kifejezésről van szó, fontos viszont megjegyezni, hogy az elnevezés semmiképpen sem takart valamilyen városjogi kategóriát, $\mathrm{s}$ főleg nem olyat, amely országos szinten csakis itt fordult volna elő. Mind a hat, Máramarosban fekvő városias településünk jogi értelemben véve egyszerü oppidum volt.

${ }^{2}$ Csak az északkeleti országrészben még további öt királyi mezőváros volt a 15. században. Gulyás 2013. 332. Országos szinten a királyi mezővárosok száma talán néhány tucatnyi lehetett.

${ }^{3} \mathrm{CJH}$ 708-709. 
értelemben, vagy jelentőségüket tekintve valóban egy szinten álltak volna a koronavárosok azokkal.

Ez a nem teljesen szokványos helyzet több tényező együttes meglétének volt köszönhető. A városfejlődés lehetőségeit Máramarosban alapvetően a korai és a középkoron túl is sokáig fennálló királyi birtoklét, a kollektív kiváltságlevél, a német hospesek kezdeti jelenléte és sajátos joggyakorlata, valamint az összes közül a legfontosabb: a királyi sókamara és a sóbányászat, ezek mindenkori poltitikai jelentősége, erős gazdaság- és társadalomformáló jellege határozta meg. Természetesen a városfejlődésben máshol is szerepet játszó piaci viszonyok, a demográfiai tényezők (a viszonylagos népességkoncentráció), valamint a távolsági kereskedelem (esetünkben leginkább a sókereskedelem) jelentősége sem megvetendő ebből a szempontból, de magam úgy látom - még ha hordoz is magában veszélyeket egy ilyen kijelentés - hogy máramarosi mezővárosaink esetében ezeknek valamivel kevesebb szerep jutott, mint másutt.

Mindezen sajátosságok ellenére a középkori Máramaros megye területe nem tartozik a tudományos igényü munkákban megfelelően feldolgozott régiók közé. Múltjával főként néhány szakmai jellegü, de már jócskán elavult mü foglalkozik csupán, emellett pedig csak kevés, köztük néhány történeti kérdéseket egyáltalán nem taglaló megyemonográfia született Máramarosról a 19-20. században. Igaz, az elmúlt néhány évben már több, magas szintű feldolgozás is napvilágot látott, ezek azonban általában a középkor utáni évszázadokat vizsgálják, azaz témánk szempontjából csak kevésbé relevánsak.

Az 1990-es évektől a magyar nyelvű helytörténeti irodalom dicséretesen fellendült ugyan a térségben, ezek a munkák viszont - a helytörténetírás jól ismert sajátosságainak megfelelően - változó színvonalat képviselnek, mind a hivatkozásaikat (vagy azok hiányát), mind adataik és megállapításaik helyességét és megbízhatóságát tekintve.

A főként a helyi magyar értelmiség által jegyzett hasonló könyvekben általános tendencia az elfogultság és a koronaváros-szerep túlértékelése. Persze ez bizonyos szempontból érthető is: a jelenségben a helyi magyarságnak a 20. század viharaiban kialakuló erős fenyegetettségérzése, a megmaradással kapcsolatos félelmei köszönnek vissza.

Érezhető az is, hogy a koronaváros-csoportnak és a királyi hatalomnak az elidegeníthetetlenségből származó szoros kapcsolata, és a privilegizált státus hosszú évszázadokra történő „,konzerválódása”4 egyfajta jól érzékelhető büszkeséget eredményezett a helyiek körében, a koronabirtok

\footnotetext{
${ }^{4}$ Csatáry György szerint kiváltságaikat és birtokaikat a kamarával szembeni perben a koronavárosok csak 1834-ben vesztették el. Az mindenképpen kijelenthető, hogy1869 után a rendezett tanácsú várossá váló Sziget kivételével mindegyikük egyszerü nagyközség lett. Csatáry 2011. 7.
} 
mint életkeret történeti hagyománya pedig mindmáig a kárpátaljai magyar identitás meghatározó alkotóeleme.

A történeti feldolgozások tekintetében megmutatkozó hiány még feltünőbb, ha a terület középkorára gondolunk. A máramarosi koronavárosok Mohács előtti történetének eseményeit modern és tudományos igényű feldolgozásban senki sem írta még meg, holott a kutatási lehetőségek elmúlt években tapasztalható látványos javulása, egészen konkrétan a középkori forrásanyag digitális elérhetősége ezt már bőven lehetővé, mi több, indokolttá tenné. ${ }^{5}$

Az alábbi rövid és tájékoztató jellegű bibliográfiai összefoglalóban elsősorban a térség és az itt található mezővárosok történetének középkorára kívánok koncentrálni. A későbbi történetükre vonatkozó, jóval nagyobb mennyiséget kitevő forrásközléseket és feldolgozásokat nemrégiben részletesen ismertette Glück László. ${ }^{6}$

Az első terjedelmesebb és megemlítendő történeti munka a szigeti gimnázium tanárának, Simonchicz Incének a tollából származik, aki a 18. század végén írt művében a megye történetének különböző kérdéseit tárgyalta a korra jellemző tudományos szinten. A dolgozat kéziratban maradt. ${ }^{7}$

Természetesen Máramarosról a nagyobb honismereti, statisztikai, illetve földrajzi vonatkozású munkák is egyre inkább megemlékeztek a 18. és 19. században. Már Bél Mátyás is tervezte vármegye-monográfia sorozatában Máramaros ismertetését, de ebben halála végül megakadályozta. ${ }^{8}$ Ezzel szemben megjelent, s így említi is a területen lévő településeket Vályi András és Fényes Elek honismereti munkája is, főként korai történetükre vonatkozólag azonban ezek sem tartalmaznak igazán használható információkat. ${ }^{9}$

\footnotetext{
${ }^{5}$ A máramarosi mezővárosok középkorára lásd összefoglalóan Györffy IV. 112-127. Csánki I. 445. Későbbi történetükre Glück 2007. 427-445. A városok történetére vonatkozó okleveleket a Magyar Nemzeti Levéltár digitális adatbázisa segítségével gyüjtöttem össze (DL-DF CD-ROM). A kiadatlan oklevelek fényképmásolatait a Magyar Nemzeti Levéltár interneten elérhető felülete felhasználásával olvastam: http://mol.arcanum.hu/dldf/opt/ a110505htm?v=pdf\&a=start (A középkori Magyarország levéltári forrásainak adatbázisa. Letöltés ideje: 2014. február 15.)

${ }^{6}$ Glück 2013. 45-70. A 18. század közepétől az 1880-as évekig terjedő időszak helyi vonatkozású, de kisebb jelentőségü, részben történeti jellegű munkáit (Tordai Balog Márton, Réthy Ferenc, Hary Péter, Tóth János dolgozatait) tartalmi szempontból összefoglalóan ismerteti Szilágyi 1889a. 11-15.

${ }^{7}$ Simonchicz.

${ }^{8}$ Szilágyi 1889a. 11.

${ }^{9}$ Vályi 1796. II. 194-195., Uo. II. 571-574. Huszt várának eseményeiről néhány sorban azonban beszámol Vályi. II. 205-208., III. 405., III. 469-470., III. 640; Fényes 1851. I. 119., 126., II. 129-130., 191., 306. stb.
} 
A legelső, valóban tudományos szintet képviselő történeti vázlat bő fél évszázaddal később született. A széles körü érdeklődésű és a történeti problémákra roppant fogékony Wenzel Gusztáv 1857-ben írt munkájában foglalkozott részletesebben Máramaros vármegye középkori történetével. Rövid művének nagy erénye, hogy több oklevelet szó szerint is közölt, igaz, az általa ismert források meglehetősen csekély számúak voltak. ${ }^{10}$ Megállapításainak egy részét még ma sem hagyhatjuk figyelmen kívül.

Ezután azonban újabb hosszabb szünet következett. Igaz ugyan, hogy Szilágyi István akadémikus, a máramarosszigeti líceum igazgatója 1876ban a Magyar Orvosok és Természetvizsgálók ugyanazon évben, Szigeten tartott 19. nagygyűlésének alkalmából megjelentette Máramaros vármegye egyetemes leírása című terjedelmes munkáját, azonban ez a 19. században divatossá váló megyemonográfiák útját követve kizárólag kurrens statisztikák felhasználásával próbált átfogó és friss képet rajzolni Máramaros megye korabeli helyzetérôl. A müben a szerző lelkiismeretesen kitért a természetföldrajzi jellemzőkre, a különféle ásványkincsekre, a növényés állatvilágra is. A társadalmi viszonyokkal kapcsolatosan foglalkozott a közigazgatással, oktatással, a területen élő vallási felekezetekkel, illetve az egyes nemzetiségek elterjedésével, néprajzával, népszokásaival. A mű záró részében a gazdasági viszonyokat elemzi. Nagy kár, hogy a jelentős, bő ötszáz oldalnyi, igen adatgazdag monográfia gyakorlatilag egyetlen sorban sem utal a megye és az ott fekvő települések korábbi történetére. ${ }^{11}$

1900-ban Nyegre László foglalta össze ugyanígy a Máramaros megyével kapcsolatos ismereteket. Azonban még szúkebb szemszögből: elsősorban a gazdasági viszonyok, a megye gazdasági helyzete érdekelte. Az összefoglaló egy gazdasági szempontok alapján megindított sorozat részeként jelent meg (a Magyar Közgazdasági Társulat szervezésében), ebből következőleg pedig fel sem merült a múvel kapcsolatosan a történeti kérdések tárgyalásának igénye. ${ }^{12}$

Hasonló úton járt Héder János 1902-ben megjelentetett, Máramaros vármegye címet viselő, rövid monográfiájában. Ebben a Szilágyi által is alkalmazott tematikát követve rajzolt fel átfogó, de elfogult, a szűkebb pátriája iránti szeretettől átitatott hangvételü képet Máramarosról, anélkül

\footnotetext{
${ }^{10}$ Wenzel 1857. Az oklevélközlések fontosságát a szerző is hangsúlyozza. Publikálásuk főleg azért volt fontos a dolgozat keletkezésekor, „mert Máramaros - mint Szilágyi István helyesen mondta - a magyar diplomatikára nézve még terra incognita". Uo. 5.

${ }^{11}$ Szilágyi 1876. Szilágyi István személyére és a térség forrásainak összegyüjtésében játszott szerepére lásd Glück 2013. 36-37. Ugyanő volt az, aki például a szigeti református egyház és a líceum történetét is megírta. További munkái viszont nem középkori témában születtek, hanem leginkább az azt követő korszakokkal foglalkoztak. Glück 2013. 47-48.

${ }^{12}$ Nyegre 1900. Az a kevés megállapítás, amit a mű bő féloldalas felvezetésében tesz, nagyrészt szintén nem felel meg a valóságnak: ilyen, miszerint Máramaros, mint vármegye 1199ben fordult elő elsőként, és hogy a huszti vár „combinative” IV. Béla alatt épült volna. Uo. 3.
} 
azonban, hogy a terület múltjáról egyetlen szót is ejtene. ${ }^{13}$ Múvét egyértelműen javító szándékkal, a megye gazdasági életének, felvirágzásának elősegítése céljából írta.

A 19. század végén aztán lassan pozitív változás következett be a megye középkori történetének kutatásában, egyre több használható publikáció jelent meg ugyanis a témában. A megyetörténet irányában megnövekedett érdeklődést jól jelzi, hogy a Magyar Történelmi Társulat 1889 augusztusában Máramarosszigeten tatotta rendes nagygyűlését, amelynek során a szokásos társulati jellegü ügyek mellett a régió történetével kapcsolatos fontos kérdések is terítékre kerülhettek. A nagygyülés jelentőségét mutatja, hogy a korabeli magyar történettudomány számos jól ismert személyisége is részt vett rajta. Ebből a szempontból elég csak Thaly Kálmán, Csánki Dezső, Márki Sándor, Szádeczky Lajos, Nagy Iván, Demkó Kálmán, Kandra Kabos, Szabó Károly és Fejérpataky László nevét megemlíteni. ${ }^{14}$

Az esemény gyümölcseként a már említett Szilágyi István közölt a Századok soron következő, 1889. évi pótfüzetében egy rövid, ám annál fontosabb kérdéseket érintő tanulmányt. ${ }^{15}$ Szilágyi a terület korai, $12-13$. századi történetével kapcsolatosan született írásában röviden kitért a románság betelepedésére, a sóbányászat kezdeteire és az egyházi viszonyokra is. Szintén a pótfüzetbe került Csánki Dezső egy dolgozata is, amely az első tudományos jellegű beszámoló volt a románság Máramarosba telepedéséről, berendezkedéséről, más román településterületekkel történő párhuzamba állításáról. ${ }^{16}$ Az ugyanebben a számban szereplő Apsai Mihályi János írása pedig már mintegy az általa később szerkesztett okmánytár előzményének is tekinthető talán. Ebben gyors áttekintést adott a megye középkori és későbbi forrásairól, közülük pedig több oklevelet részletesebben ismertetett. ${ }^{17}$

Csánki máramarosi kutatásait felhasználta később alapvető történeti földrajzi munkájában is. Ilyen értelemben ő volt tehát az első, aki a korabeli lehetőségekhez mérten minden elérhető forrásra kiterjedő gyűjtést végzett a témában a koronavárosok történelmével kapcsolatban. Igaz, művének adattárjellegéből egyenesen következik, hogy nem foglalkozott a megye múltjával kapcsolatos nagyobb összefüggésekkel, de így is temérdek oklevelet dokumentált mind birtok-, mind család-, mind településtörténeti

\footnotetext{
${ }^{13}$ Héder 1902.

${ }^{14}$ Lásd Szádeczky Lajos részletes beszámolóját a kirándulás történéseiről! Szádeczky 1889.

${ }^{15}$ Szilágyi 1889.

${ }^{16}$ Csánki 1889.

${ }^{17}$ Mihályi 1889.
} 
vonatkozásban, fogódzót adva ezzel a későbbiekben a Máramarost kutatók számára. ${ }^{18}$

A lassan meginduló kedvező folyamatok, azaz a megye történetének a helyi múvelt közvélemény előtti felértékelődése után az igazi áttörést az ügyben az jelentette, hogy 1900-ban Mihályi János közzétette a Máramarosi diplomák a XIV. és XV. századból címet viselő terjedelmes okmánytárát. Ez a vármegye történetének tanulmányozásához szükséges legfontosabb oklevelek teljes latin szövegű közlését tartalmazta és tette elérhetővé a téma iránt érdeklődők számára. ${ }^{19} \mathrm{~A}$ forráskiadvány egy tervezett megyemonográfia első lépéseként született. Mivel munkája több olyan oklevelet is magában foglal, amelyek mára eredetiben már nem elérhetők, igen nagy szolgálatot tett vele a térség középkora iránt érdeklődő kutatók és helytörténészek számára.

A helyi sótermelés kérdése is egyre inkább az érdeklődés előterébe került: Schmidt László 1901-ben megjelent néhány oldalas tanulmányában foglalta össze a környék sótermelésének történetét, bár kevés konkrét adattal dolgozott, s azok is főleg a 17-18. századra vonatkoztak..$^{20}$

Összességében tehát azt látjuk, hogy a századfordulóra a helyi értelmiség figyelme mind erősebben fordult a megye történetének feltárása felé, $\mathrm{s}$ a publikációk számának lassú növekedésével egyre inkább megérett az idő egy összefoglaló megyetörténet megírására is.

Az imént említett lokális értelmiség sorába tartozott az a román görög katolikus családból származó, de végül a római katolikus hitre tért pap is, aki Wenzel Gusztáv után elsőként vázolta fel nagyobb ívben Máramaros történetét. Pap József munkája a középkori előzményektől csaknem saját koráig követte végig az eseményeket, így azt mondhatjuk: ez az első, szisztematikusan felépülő és valóban nagyobb lélegzetü, ugyanakkor tudományos szempontokat is többé-kevésbé már magáévá tevő összefoglaló a megyéről.

Az 1909-ben megjelent mú bevezetőjében visszautalt az azóta elhunyt Szilágyi munkásságára, akitől elmondása alapján mindenki a megye történetének megírását várta korábban, végül sajnálatos módon, hiába. ${ }^{21}$ Pap a nem sokkal korábban megjelent okmánytárra is támaszkodva ismerteti Máramaros legfontosabb történéseit a kezdetektől egészen 1776-ig. A hivatkozásokat és bibliográfiát is nélkülöző könyvecske ennek köszönhetően kifejezetten adatgazdag, több helyes megállapítást tesz, és számos későbbi történeti munkának a vezérfonalává vált. Igaz, hivatkozások híján, adatait nem minden esetben lehet leellenőrizni.

\footnotetext{
${ }^{18}$ Csánki. I. 445.

${ }^{19}$ Már. Dipl. A gazdag forrásgyűjteményt napjainkig rendszeresen felhasználja a kutatás.

${ }^{20}$ Schmidt 1901.

${ }^{21}$ Pap 1909. 3.
} 
Az ezt követő években a középkori Máramarosról írt publikációk száma örvendetesen megnőtt. Még a Pap-féle monográfia megjelenésének évében közölt Petrovay György, a megyei levéltár levéltárosa a Történelmi Tárban egy újabb, a középkori Máramarosra adatokat nyújtó oklevélgyüjteményt. ${ }^{22}$ Majd ugyanő, két évvel később a máramarosi román beköltözőkről tett közzé egy alapvető tanulmányt a Századok hasábjain. ${ }^{23}$ Szintén 1911-ben Iványi Béla egy mai napig gyakran idézett dolgozattal járult hozzá a máramarosi sóbányászat jogi hátterének és munkaszervezetének teljesebb megismeréséhez. ${ }^{24}$

A századfordulóra örvendetesen megerősödő pozitív folyamatoknak, azaz a megye és a koronavárosok középkori és későbbi történetének feltárására irányuló törekvéseknek a 20. század elejétől kialakuló politikai helyzet azonban hosszú időre gátat vetett. Az első világháború és az azt lezáró békerendszer alapvetően változtatta meg a kutatási lehetőségeket. A korábban egységesen Magyarország részét képező Máramaroson több állam (Csehszlovákia, Szovjetúnió, Románia) is osztozott. A források jelentős része ezután gyakorlatilag hosszú időn keresztül - bizonyos szegmensekben egészen máig - részben vagy teljes egészében hozzáférhetetlenné vált.

Ennek ellenére is születtek azért fontos munkák a 20. század közepétől. Megemlítendő, hogy 1940-ben Szabó Zoltán írt egy rövid, a területen élő etnikai csoportokra fókuszáló összefoglalót Máramarosról, melyben a legkorábbi időktől a 20. századig vezeti végig nagy vonalakban a terület történetét. ${ }^{25}$ Fontosabb ennél, hogy megszületett az első, „komplexnek” tekinthetö, alapvetően társadalomtörténeti ihletésű megyetörténet, amely a Mályusz-tanítvány, Bélay Vilmos tollából származik, és 1943-ban jelent meg. ${ }^{26}$ A mú a 18. század elejéig dolgozta fel Máramaros törénetét, azon belül is leginkább a társadalmi és etnikai viszonyokra fókuszálva. Munkája a népiségtörténeti iskolából kiinduló, annak céljait magáévá tevő megyemonográfiák sorába illeszkedik, s azt lehet mondani, hogy máig az egyik legjobban használható, tudományos igénnyel megírt munka Máramaros történetének megismeréséhez, amelyben szót ejt a korai időszak, azaz a betelepítés eseményeiről, a sóbányászatról, de hosszabban értekezik a románság beköltözéséről és megtelepedéséről is. A dolgozatot a korabeli né-

\footnotetext{
${ }^{22}$ Petrovay 1909.

${ }^{23}$ Petrovay 1911.

${ }^{24}$ Iványi 1911.

${ }^{25}$ Szabó Z. 1940.

${ }^{26}$ Bélay 1943. A mű kronológiai értelemben vett folytatása szemszögünkből kevésbé lényeges: Bélay Vilmos: Máramaros vármegye társadalma és települései: a megye betelepülése a 18. század elejétől. Budapest, 1943.
} 
piségtörténeti monográfiák tematikáját követve a különféle településeken élő magyarságot, azok személyneveit dokumentáló adattár zárja.

A második világháború utáni években sokáig csupán kevés olyan publikáció született, amely magyar részről mélyebben foglalkozott volna Máramaros történetével. Ez persze nem jelenti azt, hogy különféle részkérdésekről ne születtek volna lényeges megállapítások, de sajnos az ilyen tanulmányok száma is csekély. ${ }^{27}$

Az 1970-es évekből ugyanakkor mindenképpen szólni kell B. Gábor Zsuzsának a Magyar személynévi adattárak 5. köteteként megjelent monográfiájáról, amely Visk történeti családneveinek nyelvészeti vizsgálatát nyújtja. ${ }^{28} \mathrm{~A}$ mű utal a középkori előzményekre is, családnévi adatai pedig egészen a koraújkorig mennek vissza.

A máramarosi sóbányászat ügye is újra előkerült. Az 1980-as évek második felében Kovássy Zoltán és Kerekes Árpád folytatott rövid publikációkban vitát a középkori máramarosi sóbányászat kialakulásának és a bányamunkások szerveződésének, általános helyzetének, valamint társadalmi megmozdulásainak kérdéséről. Tegyük hozzá azonnal, egyikőjük sem történész, érdeklődésük abból következett, hogy szakmabeliek, bányamérnökök voltak. ${ }^{29}$

Az 1990-es évek szabadabb légköre, amint azt említettük, a helytörténeti irodalom fellendülését eredményezte. Mindenképpen megemlítendők ezek közül a beregszászi tanítóképző főiskolán oktató Csatáry György vegyes tematikájú müvei és forrásközlései. 1993-ban megjelent tanulmánykötetében a Kárpátalja történetével kapcsolatosan különféle levéltárak anyagából kiválogatott forrásokat ismertet a középkortól kezdve, míg a mú további része egészen a 20 . századig vonatkozólag tartalmaz kisebb írásokat és forrásközléseket. ${ }^{30} \mathrm{~A}$ következő évben kiadott forrásgyüjteménye 17. és 19. század közötti iratokat tesz közzé. ${ }^{31}$ A nemrégiben, 2011-ben megjelent kötete pedig az öt város levéltárának tartalmi kivonatát nyújtja, átfogó képet adván a középkorra vonatkozó legfontosabb oklevelekről is. $^{32}$

${ }^{27}$ Ezek közül fontos például megemlíteni például Györffy György Máramarossal foglalkozó, magas színvonalon megírt fejezetét monumentális történeti földrajzi munkájából. Györffy IV. 112-127.; Mályusz Elemér a máramarosi sóbányászok helyzetéről tett fontos megállapításokat. Mályusz 1988. 81-83. Stb.

${ }^{28}$ B. Gábor 1975.

${ }^{29}$ Kovássy 1986., Kerekes 1988., Kovássy 1988.

${ }^{30}$ Csatáry 1993.

${ }^{31}$ Csatáry 1994.

${ }^{32}$ Csatáry 2011. 
Ugyanígy a kilencvenes évektől datálható pozitív fejlemény, hogy a szabadabb levegőt szívó helyi értelmiség figyelme egyre inkább szűkebb pátriája történelme felé fordult, és ez szerencsére a honismereti irodalom felvirágzásában is megmutatkozott. Így például megírták két máramarosi mezőváros történetét is, Técsőét és Viskét. ${ }^{33}$ Született emellett még egy, az öt város múltját tömören és vázlatosan összefoglaló honismereti jellegű kismonográfia is. ${ }^{34}$ Néhány rövidebb, folyóiratokban megjelent tanulmány ugyanakkor Máramaros nemzetiségi viszonyaival, illetve néprajzi jellemzőivel is foglalkozik, igaz csak roppant tömören. ${ }^{35}$

A belefektetett energiát és az elhivatottságot is méltányolva az embernek azonban összességében mégis az az érzése támad, hogy sajnos nem sikerült jelentősen túlhaladni az ötven-száz évvel ezelőtti eredményeken, a terület középkori múltjának felvázolásában ezek a munkák főként a már hivatkozott nagy elődök múveinek megállapításait ismételgették. ${ }^{36}$

Ennél jobban áll a helyzet azonban az egyes részkérdéseket érintő munkák ügyében. Ilyen például a huszti vár, amelynek történetéről tudományos és tudományos- ismeretterjesztő munkák is születtek. ${ }^{37}$ Emellett ermészetesen a román történettudomány képviselői is foglalkoztak az elmúlt fél évszázadban Máramaros korai történetével, középkori egyháztörténetével, ezeket a munkákat azonban olykor - főleg a régebbi kiadásúakat - elfogultság jellemzi. ${ }^{38}$

A középkori erdélyi és máramarosi sóbányászattal kapcsolatos kutatások terén főleg Draskóczy István tanulmányait érdemes újabban megemlíteni, aki több írásában is érinti a kérdést, s emellett 2005-ben a geológus Réthy Károly tollából született még egy, a máramarosi sóbányászat fejlődését nagy vonalakban áttekintő rövid dolgozat, illetve nemrégiben Tóth Jánossal közösen foglalták össze monografikus formában a magyarországi sóbányászat és -kereskedelem történetét, melyben sok középkori adatot is hoznak. ${ }^{39} \mathrm{~A}$ máramarosi sókereskedelem és a sókamara működé-

\footnotetext{
${ }^{33}$ Szöllősy 1994. és Czébely 2002.

${ }^{34}$ Igyártó 2005. Ennek lerövidített változata korábban az Együtt című folyóirat 2003. évi számában látott napvilágot. Igyártó 2003. A munka alapvetően honismereti jellegú írásnak tekinthető.

${ }^{35}$ S. Benedek 1999., Gábriel 1988.

${ }^{36}$ Ez alól leginkább Czébely Lajos korrektül lábjegyzetelt, ímént már hivatkozott könyve jelent kivételt. Czébely 2002.

${ }^{37}$ Deschmann 1991; Szoleczky 2005; Szoleczky 2012.

${ }^{38}$ Erre a legjobb példa Filipaşcu 1940. Lásd még Diaconescu 1998-1999.

${ }^{39}$ Draskóczy 1994; Draskóczy 2004; Draskóczy 2005; Draskóczy 2008; Draskóczy 2009b; Draskóczy 2010; Draskóczy 2014; Réthy 2005; Réthy-Tóth 2012.
} 
sének kora újkori jellemzőit - több, középkorra is vonatkoztatható adattal - Glück László foglalta össze. ${ }^{40}$

A 16. század közepi máramarosi birtokviszonyokat is tárgyalja Maksay Ferenc 1990-ben publikált terjedelmes munkája. Adatai a középkor végi helyzet vizsgálatához is jól felhasználhatók. ${ }^{41}$ Szintén nemrégiben Tóth Péter elemezte a Técső helynév eredetét, egyúttal a település keletkezésének vitás kérdéseit is újra felelevenítve, a korábbi helytörténeti irodalomban meggyökerezett német származást cáfolva. ${ }^{42}$ Érintette emellett a máramarosi mezővárosok fejlődésének kérdését Kubinyi András, aki több más településsel együtt ezeknek - az általa bevezetett terminológiával élve: „,központi helyeknek" - is összegezte fejlődésbeli vonásaikat, és kiszámította a centralitási pontjaikat. ${ }^{43}$

Szerencsére kifejezetten jól áll a Mohács utáni, kora újkori Máramaros kutatásának helyzete. Glück László ugyanis több tanulmányában, illetve frissiben megvédett disszertációjában is részletesen foglalkozott a koronavárosok társadalmával, berendezkedésével, gazdasági viszonyaival - és mint fentebb már láthattuk - sótermelésével és sókereskedelmével. ${ }^{44}$

Ha összegezzük a fentebb ismertetett művek alapján a középkori máramarosi városfejlődésre vonatkozó szakirodalom általános helyzetét, akkor meg kell állapítanunk, hogy kevés az igazán fajsúlyos, mérvadónak tekinthető munka, a koronavárosok Mohács előtti történetét komplex módon - az említett üdítő kivételnek számító, kora újkort tárgyaló dolgozatokkal ellentétben - még nem dolgozták fel.

Ez nem is annyira a sokszor szidott forráshiány eredménye, hanem inkább a források jellegéből következik. A Mihályi János nevéhez füződő terjedelmes okmánytár és a néhány kisebb, fent már érintett forrásközlés mellett a különféle nagyobb - és máig kiadás alatt álló - oklevéltár-sorozatokban is lehet ugyan szép számmal máramarosi vonatkozású okleveleket találni, ezek azonban jellegüket tekintve igen egyoldalúak. Legnagyobb részben ugyanis a környékbeli falvakban birtokokat szerzö, főleg román származású nemesség különféle birtokügyeiről számolnak be, kisebb részben pedig a sókamarai igazgatásra és a településeknek a királyi hatalommal való kapcsolatára utalnak. A kiváltságleveleken, a néhány, mezőváro-

\footnotetext{
${ }^{40}$ Glück 2008a., Glück 2009a. Szintén több adatot tartalmaz a kora újkori máramarosi sóbányászatra nézve Kulcsár 1991.

${ }^{41}$ Maksay 1990. I. 463-486.

${ }^{42}$ Tóth 2008.

${ }^{43}$ Kubinyi 2000. 71-99. Ugyanezen a nyomvonalon haladt, azaz a városias funkciókra és a térbeli elhelyezkedésre koncentrált elsősorban Pálinkó 2012, amely - bár röviden - a 14. századi Máramarost is tárgyalta.

${ }^{44}$ Glück 2007., Glück 2008b., Glück 2009b., Glück 2010., Glück 2013. Utóbbiban részletesen összefoglalja a Mohács utáni korszakkal kapcsolatos szakirodalmat és a vizsgálható forrásokat is. Uo. 16-45., 50-52.
} 
sok által kibocsátott oklevélen, a sóbányákkal kapcsolatos statútumokon, valamint a mezővárosi hivatalnokelit és a környékbeli egyházak 15. századtól fennmaradó birtokiratain kívül csak viszonylag kevés oklevél árulkodik a koronavárosok belső viszonyairól, társadalmi berendezkedéséről, gazdasági életéről, illetve jogi helyzetéről.

A 16. század közepétől viszont a fennmaradt és feldolgozható levéltári anyag mennyisége mondhatni „robbanásszerüen” megnőtt. Megjelennek az első mezővárosi statútumok a térségből, a 17. század elejéről, 1600-ból és 1614-ből pedig már teljes névsort tartalmazó népesség-összeírásokkal is rendelkezünk. A kora újkori forrásanyag, az ebben a témában született munkák óvatos felhasználása sokat árnyalhat tehát a középkori Máramarosról alkotott képen is. ${ }^{45}$

${ }^{45}$ Itt szeretnék köszönetet mondani a máramarosi mezővárosok társadalmával régebb óta foglalkozó Glück Lászlónak, egyúttal jelen kötet lektorának, aki több kora újkori és késő középkori adattal egészítette ki az általam gyüjtött anyagot. A legfontosabb helyeken külön is jelzem majd, ha az adatra ő hívta fel a figyelmemet. 



\section{A MÁRAMAROSI MEZŐVÁROSOK TÖRTÉNETÉNEK VÁZLATA A MEGTELEPEDÉSTŐL A KÖZÉPKOR VÉGÉIG}

Máramaros a viszonylag későn létrejövő megyéink közé tartozik: a valószínúleg Borsovából kiváló terület a 13. század végéig csupán egy egyszerü erdőispánság lehetett, melynek Sziget volt a központja. ${ }^{46}$ Hogy Máramaros valóban királyi vadaserdő volt az Árpád-korban, azt az első, a területre vonatkozó fennmaradt okleveles említés is igazolja. 1199-ben ugyanis Imre király Máramarosban vadászott, amikor lováról lebukott, életét pedig egy bizonyos Lőrinc ispán mentette meg. Az uralkodó háláját kifejezendő Sopron megyében ötekényi udvarnokföldet adományozott megmentőjének. ${ }^{47}$ A történetet megörökítő oklevél az első hiteles forrás Máramarossal kapcsolatosan. 12. századi és azelőtti történetéről gyakorlatilag semmi konkrétumot nem tudunk. ${ }^{48}$

De még 1271. december 31-én, a felszászi hospesek kiváltságlevelében is csak „erdőként” került említésre a későbbi megye területe. A felszásziak a privilégium szerint a Tiszán történő halászat jogát földjük határaitól egészen a „Máramaros-erdő” gyepüjéig kapták meg az uralkodótól. ${ }^{49}$ Ebben a korszakban Máramarosnak még nem lehetett igazán nagy népessége, ${ }^{50}$ és az Árpád-kori telepítések első hulláma is elkerülte, így önálló vármegyévé

\footnotetext{
${ }^{46}$ A hajdani Borsova megye központja Borzsova vára volt, ahol később Vári mezőváros alakult ki. Györffy IV. 112-113. Györffy legfőbb érve Sziget központszerepére, hogy a településsel szemközt, a Tisza jobb partján egy Fejéregyház nevű falu található, ami korai királyi kápolna jelenlétére utalhat. Borsovára lásd Németh 1975. 121-122. és Petrovics 1994.

${ }^{47}$ Az eset akkor történt, amikor a király elbeszélése szerint „in Maramorisio tempore venationis venatum ivissemus". HO II. 1-2. és Reg. Arp. I. 185. sz. Lőrincről nem sokat tudunk, még ispánságát sem ismerjük. Szabados 1999. 106.

${ }^{48}$ Györffy IV. 124. „Mindaz, mit e tekintetben a 13. század előtti időre vonatkozólag mondhatunk, nagyobb kisebb mértékben csak a történelmi combinatiok eredménye." Wenzel 1857. 8.

${ }^{49}$ Reg. Arp. II/1. 2117. sz; CDH V/1. 177.: „ad indagines sylvae Maramarosii”.

${ }^{50}$ Wenzel 1857. 7-8.
} 
szervezésére nem is volt szükség. 1299-ben még mindig csak terrának nevezik, azaz megszervezett comitatusnak továbbra sincs nyoma. ${ }^{51}$

A 14. század elejére azonban egyre inkább napirendre kerülhetett az ispáni fennhatóság kiterjesztésének kérdése. Máramarost eleinte a szomszédos Ugocsával helyezték egy kormányzat alá. A két terület első ismert közös ispánja Pok nembeli Móric fia Miklós volt, aki 1299 és 1319 között viselte az ispáni címet, de 1299 és 1303 között egyúttal még az ugocsai ispánságot is irányította. Ispánjaik ekkor még Szőllősön székelnek. ${ }^{52}$ A 14. században a tisztséget már rendszeresen betöltik. 1347-től, Lackfi András hivatalviselésétől kezdve egészen 1412-ig összevonták a szatmári és máramarosi ispáni címet, de a máramarosi comesek ezek mellett legtöbbször az ugocsai, olykor a krasznai, beregi, zempléni vagy éppen a székely ispánságot is birtokolják. ${ }^{53}$ Az ispánok listáját -1437-ig - Engel Pál gyüjtötte össze alapvető archontológiai munkájában. ${ }^{54}$ Közülük egyes helyi famíliák, így jellemzően Drág és rokonsága a máramarosi románok vajdája címet is viselték, sőt, olykor arra is van példa, hogy a huszti várnagy és a sókamaraispáni tisztséget is használták a megyei ispánok. ${ }^{55}$

Az ispáni cím megjelenése és megszilárdulása ellenére a megye szervezetének kialakulása valószínűleg a 14. század nagy részében még folyhatott, így a királyi vármegye helyett - meglehetősen ritka fejleményként - közvetlenül a nemesi megye jött létre a század végére. ${ }^{56}$ A szervezeti keretek kialakulásában az is szerepet játszott, hogy az 1360-as évektől mind több vlah kenéz szerzett birtokot és jutott országos nemességhez a területen. Ennek a lassú megyeszervezésnek, valamint Máramaros alapvetően archaikus jellegének volt köszönhető, hogy a területet sokáig nem comitatusnak, csak districtusnak nevezik a források. ${ }^{57}$

\footnotetext{
${ }^{51} \mathrm{CDH}$ VI/2. 194.: ,terram Maramorus".

${ }^{52}$ Zsoldos 2011. 167-168; Györffy IV. 112. Pok Miklós Károly Róbert egyik kipróbált bárója volt, aki valószínűsíthetően részt vett a rozgonyi csatában, később pedig az erdélyi vajda tisztét is betöltötte. Kristó 1999. 52 .

${ }^{53}$ Engel 1996. I. 152-153, 187. 1349-ben például: „Magister Andreas comes Siculorum, Brassoviensis, Szothmoriensis et Marmarusiensis”. CDH IX/1. 734-735. 1366-ban: „Nicolao, filio quondam Stephani wayuodae, Siculorum nostrorum et Zathmariensi Maramurusiensi et de Ugocha". CDH IX/3. 560.

${ }^{54}$ Engel 1996. I. 153. Lásd még Wenzel 1857. 42-43.

${ }^{55}$ Wenzel 1857. 43-44.

${ }^{56}$ Wenzel 1857. 23; Kristó 1988. 426-427.

${ }^{57}$ Így hívják 1326-ban („,in districtu Marmorosiensi” CDH X/4. 708.), sőt, még 1355-ben is: „in districtu Maramorosiensi”. Már. Dipl. 35. De 1360-ban és 1361-ben is csak terrának (Már. Dipl. 42, 50.) nevezik. 1373-ban megjelenik az „in comitatu Maramorosiensi” jelző, és úgy látszik, egyre inkább elterjed (pl. 1391: Már. Dipl. 89.), de ebben nem következetesek az oklevelek írói, hiszen még a 15. század elején is fel-felbukkan néha a régi megnevezési mód: „in districtu Moromorosiensi". Már. Dipl. 184. (1412). Szolgabíráiról és megyei gyűlésről 1368tól van adatunk, alispánjára 1383-tól. Már. Dipl. 62. Bélay 1943. 22, 25. 1408-ban újra hallunk
} 
A korai időszakban a területen még bizonyosan nem állt vár. Az Árpádkor végére mind jelentősebbé váló máramarosi települések és a termelésüket ekkoriban felfuttató sóbányák védelme miatt azonban nagy szükség volt egy királyi birtokban lévő erősségre és ezt a funkciót végül Visk töltötte be a századfordulótól. Az ekkor még Ugocsához tartozó falu és föld a vámhelyével valamikor az 1270-es évek elején, V. István korában került királyi adományként a csehekkel szemben elesett Hontpázmány nembeli Ahelleus testvéreinek, Marcellus comes fiainak, Mikónak és Csépánnak a birtokába. Mivel azonban az Ugocsát pusztító Leó herceg ruténjai az oklevelet magukkal hurcolták, Kun László 1281-ben az adományt megújította. ${ }^{58} \mathrm{~A}$ vár ekkor, a század utolsó két évtizedében épülhetett és elég későn, csak 1299-ben említik először. ${ }^{59}$

Az adományosok azonban nem sokáig örülhettek a birtoknak és a rajta álló erősségnek, ugyanis azt még 1300 folyamán megszerezte tőlük III. András, akivel kénytelenek voltak elcserélni a felkínált ugocsai Ardó és Rakasz birtokokra, valamint a lakatlan Nyírtelekre. ${ }^{60} \mathrm{Az}$ újonnan szerzett vár és birtok területe valamikor ezután került át Ugocsától az újonnan létrehozott Máramarosba. A castrum a 14. század elején azonban elpusztulhatott, mivel többet már nem szerepel a forrásokban. ${ }^{61}$ A 14 . század közepén, egészen pontosan 1353-ban tünik csak fel a huszti vár, amely Visk szerepét, a tiszai sószállító út és a sóbányák védelmét a későbbiekben ellátta, és a kialakuló nagy máramarosi királyi uradalom központjául is szolgált. Létrehozásában minden bizonnyal a határvédelem kérdése is sze-

egy nádori parancslevélben a Szigeten összegyűlt máramarosi generalis congregatioról: „,in congregatione nostra generali universitati nobilium comitatus Marmorosiensis". CDH X/4. 707-710. Wenzel 1857. 36-37.

${ }^{58}$ Reg. Arp. II/1. 2266. sz. Teljes szöveggel: CDH V/3. 87-89. A vár ekkor még bizonyosan nem állt, hiszen nem tesznek róla említést. Uo. 88.: „quamdam villam et terram Visk vocatam in comitatu Ugocha existentem". Nem fogadható el tehát az a vélemény, miszerint a vár valamikor 1271 és 1281 között épült volna. Czébely 2002. 22. Az oklevelet többször átírták (1291, 1292, 1399, 1417). Reg. Arp. II/2-3. 3117. sz. Wenzel 1857. 20.

${ }^{59}$ Ekkor III. András még „,visszaadta és a kezükön hagyta” a várat, amelyet újfent testvérük halálával, illetve Csépán hadi érdemeivel indokolt meg. Reg. Arp. II/4. 4261. sz. A falu és a vár említése: „quandam villam seu possessionem Wysk vocatam simul cum castro suo” stb. HO VIII. 445.

${ }^{60}$ Reg. Arp. II/4. 4319. sz; CDH VI/2. 253-256.: „,in concambium praefatae possessionis Visk cum castro suo et villa sub eodem existente, quasdam possessiones nostras seu villas nunc ad praedium nostrum de Ugocha pertinentes in eodem comitatu sitas, Rokaz et Fekethe Ordou quae sunt minime populosae et Nyirtelek quae est vacua et habitatoribus destituta...". Kiadta még Már. Dipl. 3-6. A birtokváltás körülményeire és a várra lásd még Pap 1909. 10-17. A viski vár szerinte egészen Huszt felépüléséig, azaz a 14. század közepéig „Máramaros védőbástyája" volt. Uo. 22.

${ }^{61}$ Engel 1996. I. 461; Szabó I. 1994. 32-33; Fügedi 1977. 211. Visk közlekedési vámjára lásd Weisz 2013. 435. 
repet játszott. ${ }^{62}$ Várnagya ekkor a nyalábi várnagyságot is ellátó Zólyomi Macska Domokos. ${ }^{63}$

Máramaros megye megszervezésének legfőbb oka az volt, hogy részben a sóbányászatnak köszönhetően a területet különféle etnikumú beköltözők kezdték el benépesíteni, így a lakosság lassan ugyan, de gyarapodott. Ez a tény az egri és az erdélyi püspökség számára is nyilvánvaló volt, ezért a két egyházmegye egyaránt meg akarta magának kaparintani a hívekkel benépesülő Máramaros tizedeit. A felek között per kezdődött, melyben az Imre váradi püspök és László titeli prépost által 1299-ben lefolytatott vizsgálat megállapította, hogy Máramaros korábban az erdélyi püspökséghez tartozott, ezért a király a javára döntött az ügyben. ${ }^{64}$

Hasonló utat járhatott be egyébként a szomszédos Ugocsa megye is, amely eredetileg szintén az erdélyi egyházmegye területe volt, de királyi döntés révén a 13. században mégis Egernek fizette a tizedet. A 14. században azonban itt is „helyreállt a rend”, és újra az erdélyi püspök szedi a dézsmát. ${ }^{65}$

Mivel azonban a területet az erdélyi püspöknek ítélő királyi rendelkezésnek valamiért mégsem lett foganatja, az erdélyi püspök 1300. január 6-án az Apostoli Szentszékhez fellebbezett. ${ }^{66}$ Minden bizonnyal sikertelenül, hiszen 1331-ben az ekkor először említett máramarosi főesperes az egri püspök alá tartozik, az 1332-1335 közötti pápai tizedjegyzék szerint pedig a területet továbbra is az egri egyházmegyéhez számították. ${ }^{67} \mathrm{Az}$ erdélyi főpásztor ezt nem hagyhatta annyiban, aminek következményeképpen 1346-ban a máramarosi vikárius, egyúttal szigeti pap és a viski plébános is esküt tett arra nézve, hogy csakis Egernek vetik majd alá magukat. Ezután azonban láthatólag végül mégis csak az erdélyi püspöknek sikerült érvényesítenie fennhatóságát, ugyanis 1404-től Máramaros a tasnádi vikáriushoz tartozik. ${ }^{68}$

Az első ismert papok a máramarosi városokban nagyjából a pápai tizedjegyzékkel egy időben tünnek fel. 1326-ban együttesen és név szerint nevezik meg a városok plébánosait. Ekkor ugyanis Boleszló esztergomi érsek - megtudván, hogy a területen lévő településeken ius archidiaconaliaval rendelkező egyházak, azok élén pedig rectorok állnak, akik tizedet is

\footnotetext{
${ }^{62}$ Engel 1996. I. 331; Engel 1977. 118.

${ }^{63}$ Fügedi 1977. 171.

${ }^{64}$ Reg. Arp. II/4. 4263. sz. illetve CDH VI/2. 193-194. A megállapítás szerint „terram Maramorus predictam esse et fuisse intra limites et terminos dyecesis Transsilvanensis". Wenzel 1857. 19.

${ }^{65}$ Kovács 1987. 57-58.

${ }^{66}$ DF 277400. Már. Dipl. 1-3. Lásd még az ügyhöz Czébely 2002. 27.

${ }^{67} \mathrm{CDH}$ VIII/3. 543; Györffy IV. 121-122.

${ }^{68}$ 1346. július 11-i oklevél. DF 209979. Kiadása: Már. Dipl. 23-26.; Wenzel 1857. 31.; Györffy. IV. 128. Az ügy fejleményeiről beszámol még Kovács 1987. 61.
} 
szednek, megerősíti őket ezekben a jogaikban, márkánként pedig 1 pondusban írja elő tartozásaikat. ${ }^{69} 1336$-ban, a bedői határjárás kapcsán említik Pál técsői plébánost. Az imént már ismertetett eskü kapcsán szerepel az 1329. évi privilégiumot a királynál kijáró Benedek szigeti, illetve György viski lelkész. ${ }^{70}$

Az elsőként, 1281-től adatolható Visk mellett a 14. század elejétől többi településünk is sorra bukkan fel a forrásokban. 1308-ban, a Descriptio Europae Orientalis említi tévesen, folyóként Szigetet, Técsőt és Visket. Huszt 1324-től jelenik meg oklevélben. ${ }^{71} \mathrm{Az}$ öt város legelső együttes említése csak 1326-ban történik, Boleszló esztergomi érsek május 14-i oklevelének ugyanazon év május 17-ére keltezett királyi átírásában. ${ }^{72}$

Van olyan elképzelés, miszerint a terület kezdeti benépesítése és a városok létrehozása a Tisza mentén Ugocsa felől fokozatosan történt volna. ${ }^{73}$ Az ilyen irányú betelepedést az mindenesetre igazolhatja, hogy első körben 1329-ben csak négy város kapta meg kollektíven a kiváltságlevelet. Az Ugocsától legtávolabbi, az Iza és a Tisza találkozásánál fekvő ötödik, Sziget - noha a többivel nagyjából egy időben bukkan fel az írásos forrásokban - csak bő két évtizeddel később 1352-ben nyerte el kiváltságait. ${ }^{74}$

A területet benépesítő hospesek azonban nem csak az öt településen telepedhettek meg, hanem ekkor még egy közeli faluban, a 15. század folyamán a huszti uradalomhoz tartozó, akkor már egyszerü jobbágyfaluban, Talaborban is kimutatható a jelenlétük. Amikor Nagy Lajos 1362-ben utasítást küldött a máramarosi szabad falvaknak, hogy felfegyverkezve lo-

\footnotetext{
${ }^{69}$ Anjou X. 195. sz; Károly Róbert az oklevelet 3 nappal később átírta. Ez az átírás említi az öt települést és papjaik nevét: János szigeti, Lőrinc hosszúmezei, Benedek técsői, György viski és György huszti rectorok vagy plébánosok. Anjou X. 202. sz. Mindkét oklevél fennmaradt a budai káptalan 1341. évi átírásában. DF 247881. Az oklevél szövege elmosódott és rendkívül nehezen olvasható: ,JJoannes de Zygeth, Laurentius de (Hozu?)mezeu, Benedictus de Thecew (?), Georgius de Vysk, et Georgius de Huzt (?) ecclesiarum plebani seu rectores de districtu seu provincia Maramorosiensi".

70 "Paulo plebano rectore ecclesie de Thechew”. Már. Dipl. 13; „dominus Benedictus rector ecclesie de Zygeth... una cum domino Georgio rectore ecclesie de Vysk". Már. Dipl. 23.

${ }^{71}$ Györffy IV. 123-127. Huszt első említése még nem településként történik, csupán a kissé megfoghatatlan "terra"-ként: „in quodam campo Luchke mezeu vocato, cadit in praedictum flumen Thicie, quod quidem flumen separat ipsam terram a terra Huszth". Elfogadhatatlan és egyetlen adattal sem bizonyítható az a teória, miszerint Técső az ezredforduló környékén jött volna létre. Szöllősy 1994. 29.

${ }^{72} \mathrm{DF} 247881$.

${ }^{73}$ A viski személynévanyag vizsgálata alapján a település alapvetően Bereg, Ugocsa, Szatmár és Bihar megyéből szerezte magyar lakosságát, míg nyelvjárási jellegzetességek alapján a Mezőséggel volt még viszonylag szoros a kapcsolat. B. Gábor 1975. 5. Ezek a személynevek azonban minden bizonnyal az alapítás után beköltözők nevei voltak, azaz nem utalnak az alapítás korszakára. Mindenesetre az Ugocsa felőli benépesedés ennek ellenére is logikusnak és elfogadhatónak tünik.

${ }^{74} \mathrm{Az}$ 1329. és 1352. évi kiváltságlevél: CDH VIII/3. 353-356. és DL 2539; Pap 1909. 21-22.
} 
vasaikkal és gyalogosaikkal csatlakozzanak Himfi Benedek szatmári ispán seregéhez, az öt város mellett a hatodik címzett Talabor volt. ${ }^{75}$

A kiváltságolással tehát a négy, majd öt szász, illetve magyar népességü máramarosi település a városfejlődés útjára léphetett. Az út rögösségét ebben a korszakban alapvetően két tényező befolyásolta. Egyrészt azok a kiváltságok, amelyek a frissiben elnyert privilégiumban benne foglaltattak, másrészt pedig az, hogy vajon a királyi hatalomnak mi lesz majd a szándéka az újonnan létrejött hospestelepekkel?

A 14. században, amely várostörténeti szempontból közismert módon a különféle településtípusok szelekciójának korszaka volt, alapvetően két eshetőség állt fenn: ha a századforduló környékén az öt város kikerül a királyi birtokból és magánúri függésbe kerül, akkor jó eséllyel mezővárosként fogja megérni a 15. századot. Ha viszont sikerül uralkodói kézben maradnia, akkor akár a királyi szabad városok szintjét is elérheti. A máramarosi mezővárosok rövid földesúri függés után, a stratégiai fontosságú sólelőhelyeknek köszönhetően királyi birtokba kerültek vissza, és végül a nem túl népes királyi mezővárosok táborát gyarapították.

A települések a középkor nagy részében királyi birtokban voltak. 1329ben a kiváltságlevélben Károly Róbert a négy helység lakóit szász és magyar hospeseinek nevezi, ${ }^{76} \mathrm{~s}$ innentől láthatólag nem is nagyon akart róluk a királyi hatalom lemondani. A királyi birtoklás folyamatossága csak rövid időre szakadt meg. A birtokszerző a Bélteki família volt. ${ }^{77} 1389$-ben Kis- és Nagytécső került a birtokukba, és ugyanekkor Hosszúmezőt is uralják. ${ }^{78}$ 1390. április 30-án Zsigmond a Huszt várához tartozó Visk birtokot a szintén a Béltekiekhez tartozó Balk vajdának és Drág székely ispánnak, illetve Oláh Jánosnak adományozta, amibe május 25-én be is vezették őket. ${ }^{79} 1392$. augusztus 10-e előtt Huszt és Sziget is az övék lett, új adomány gyanánt. ${ }^{80}$

Nem tudni pontosan, hogy meddig tartott Bélteki Drág és Balk birtoklása, de az biztos, hogy 1393. szeptember 2-án még az ő várnagyaikról esik említés Huszton, 1406-ban az öt város már újra királyi mezővárosként szerepelt, 1407-ben újra, 1413 februárjában pedig ennek megfelelően

\footnotetext{
${ }^{75}$ Engel 2001b. 76-77.

${ }^{76} \mathrm{CDH}$ VIII/3. 353.: ",hospitum nostrorum fidelium de Maramorusio Saxonum et Hungarorum, videlicet in villis Visk, Huszth, Tecsö, et Hosszúmezö".

${ }^{77}$ 1365-től a Moldvából bevándorolt Szász vajda öt fia több birtokot is szerzett a megye területén és a térségben: elsőként Konyha birtokot a tartozékokkal, s ezután Szatmárban, Szolnokban,(Kővárat), Szilágyban (Aranyos), de a távoli Pilisben is. Névadó birtokukat, Bélteket 1385-ben szerzik. C. Tóth 2012. 144-147.

${ }^{78}$ ZSO I. 917. sz; DL 7481; Már. Dipl. 89-94.

${ }^{79}$ Lelesz Stat. 28, 30. sz.

${ }^{80}$ Lelesz Stat. 40. sz. Az 1397. május 8-i királyi parancslevél alapján az iktatást megismételték. ZSO I. 4754. sz.
} 
a máramarosi ispán várnagyai (azaz királyi várnagyok) ülnek a várban. ${ }^{81}$ Az új földesurak a javak közül Técsőt 1397-ig bizonyosan kézben tartották. A birtokok elvesztése tehát valamikor 1397 és 1406 között következhetett be. ${ }^{82}$

Az eddigi elképzelések szerint az Ugocsában fekvő nyalábi uradalmat a Béltekiek 1378-tól birtokolták és 1405-ben vesztették el, az 1403. évi felkelésben való részvétel miatt. ${ }^{83}$ Ez alapján pedig logikusnak tünne, hogy a szomszédos Husztot is ekkor vették el tőlük, ugyanezen okból.

Újabban viszont felvetődött, hogy a nyalábi birtokszerzést igazoló, a kolozsmonostori konvent által kibocsátott oklevél a 15. század utolsó harmadában keletkezett hamisítvány. Eszerint pedig a birtokot valóban 1378ban kapta kézhez Balk, de csak honorbirtokként, s azt 1402-ben, halálával vesztette el, nem pedig 1405-ben, a felkelésben játszott szerepük retorziójaként. Perényi Péter ezután 1402-től honorként, 1405-től pedig a felkelés leveréséért kapott jutalmul adományként birtokolta Nyalábot. ${ }^{84}$ Ha pedig ez a vélemény megáll, akkor a máramarosi mezővárosok elvesztése is talán ekkoriban, 1403-1404 környékén történhetett. ${ }^{85}$ Innentől fogva az uradalom királyi, illetve királynéi kézben van, a középkor végén pedig, 1514-től az elidegeníthetetlen birtokok között sorolják fel.

A máramarosi bányavidék sorsát a következő években a helyben lévő sókamara politikai súlya határozta meg. A 15. századtól kezdve igen sok adattal rendelkezünk a kamara vezetőivel kapcsolatban, a királyi kama-

\footnotetext{
${ }^{81}$ Már. Dipl. 143: „opidorum nostrorum regalium Sigeth, Longiprati, Techew, Wischk et Hawsth"; Már. Dipl. 148.: „literas efficaces opidorum nostrorum regalium Sziget, Longiprati, Techeu, Wisk, Huszth"; Engel 1996. I. 331.

${ }^{82}$ ZSO I. 5055, 5160. sz; Zsigmond 1405. február 20-i parancslevele beszámol arról, hogy a néhai Balk máramarosi vajda (,,quondam magister Balk voyvoda Maramarosiensis" - Már. Dipl. 130.) és fia, Demeter az Úrmezeiek birtokain hatalmaskodtak, illetve a Talabor vizét elterelve elárasztással veszélyeztették Úrmezőt. Ha a térképre nézünk, egyértelműnek tűnik, hogy Balkék a Talabor vizét csakis técsői birtokosként terelhették el. A Zsigmond-kori oklevéltár regesztája szerint, amely Mihályi János forrásközlését használta fel, a hatalmaskodás 10 évvel azelőtt történt, tehát 1395-ben. Kapcsolodó forrásunk szövege viszont épp ennél a fontos résznél hiányos. Figyelembe véve, hogy az oklevél elveszett, az események dátuma már sajnos nem ellenőrizhető, de a töredékes szövegrész alapján, már amennyiben Mihályi olvasata a rossz állapot ellenére is helyes volt (,,--- decima instaret revolutio"), valóban ez a datálás tűnik elfogadhatónak, azaz valóban ekkor történhetett a hatalmaskodás. ZSO II. 3670. sz. Bélay 1943. 26-27.

${ }^{83}$ Engel 1977. 137. Nyalábi birtoklásukra összefoglalóan: Komáromy 1894. 503-507.; A felkelésben történő részvételükre: ZSO II. 2966. sz.

${ }^{84}$ C. Tóth 2012. 148-161. A feltételezhetően hamis oklevél jelzete DL 26566. Vö.Engel 1996. I. 377 ;

${ }^{85}$ C. Tóth 2012. 161-163. A Béltekiek további történetére lásd Horváth 2012. és Neumann 2012.
} 
raispánok - többnyire magyarok - rendszeresen megjelentek az oklevélanyagban. ${ }^{86}$

A 15. században a királyi oklevelek alapján a máramarosi mezővárosok stabilan királyi, majd királynéi birtokban vannak, egyetlen olyan adatot sem ismerünk, amely ennek a megállapításnak ellentmondana, azaz amely szerint más birtokolná a mezővárosok valamelyikét. 1424-ben Técsőt az országbíró királyi városnak nevezi. ${ }^{87} 1435$-ben Técső királyi oklevélben királyi oppidum. ${ }^{88}$ 1472-ben Mátyás oklevelében is mindegyik az. ${ }^{89}$ Az 1498. évi statútumban a király huszti, técsői és szigeti sóvágóiról beszél..$^{90} 1515$-ben és 1519-ben II. Ulászló nevezi Szigetet királyi mezővárosnak. ${ }^{91} \mathrm{Az}$ adatokat a végtelenségig lehetne sorolni.

A fent felvázolt helyzet I. Mátyás uralkodása idején némileg megváltozik. Ekkor ugyanis, valószínúleg 1480 körül az uradalom és a sóbányák a királyné birtokaihoz kerültek át. Az sem kizárt azonban, hogy már ezt megelőzően, 1476-ban is a királyné kezében volt az uradalom, hiszen már ekkor intézkedett máramarosi ügyben..$^{92} \mathrm{~A}$ királynő Mátyás halála után a királynéi birtokokat sajátjaként kezelte, egészen addig, amíg 1497 novemberében vissza nem vették tőle. Ezután Anna királyné birtokában volt a huszti uradalom, 1506. évi haláláig. ${ }^{93}$

Emellett, a Jagellók idején egy rövid időszakra többen is bírják zálog gyanánt a kamarát az uradalommal együtt. 1510-1511-ben Sárkány Ambrusnál és Szalkai Lászlónál van zálogban Huszt vára és a sókamarák, azonban a király azokat 1511. június 15-én Perényi Gábor ugocsai ispánnak és királyi főkamarásmesternek köti le, az Opaviai Hercegség visszaváltásához szükséges összeg előteremtésének céljából. Perényi vállalta, hogy az említettektől 7000 forintért kiváltja a javakat, illetve még további 6000

\footnotetext{
${ }^{86}$ Anélkül, hogy teljességre törekednénk: Grapiolus, 1439 (DL 13358); Szegedi Máté és Odoardo Italicus 1448 (Zichy IX. 204.); Istenmezei Albert, 1458 (Bártfa I. 1031. sz.); Kinizsi Pál, 1467 (Hunyadiak kora XI. 293.); Besenyői Bertalan, 1469 (Ugocsa 83.); Paládi Ferenc, 1476 (DL 17804); Tárcai János, 1499 (Bártfa I. 3434. sz.); Butkai Péter, 1504 (DL 88911); Batthyány Benedek, 1506 (DL 101380); Perényi Gábor, 1513 (DL 71127); Csebi Pogány Zsigmond, 1522 (DL 89158). A középkor végi máramarosi kamaraispánokra lásd Draskóczy 2005. 85.,13. jegyzet.

${ }^{87}$ "per cives et hospites regales de Theucheu”. Már. Dipl. 264.

88 "cives oppidi nostri Thechew vocati". Már. Dipl. 300.

${ }^{89}$ Már. Dipl. 516.: „universorum civium et inhabitatorum oppidorum nostrorum Huszth, Szigeth, Hosszumező ac Visk et Tetseu".

90 "incisores salium nostrorum in Hwzth, Theczew et Zygeth commorantes". Már. Dipl. 616-617.

${ }^{91}$ DF 212556, DF 212557.

${ }^{92} 1480$ körülre teszi ezt Draskóczy 2005. 85; A huszti Szent Erzsébet egyháznak kiutalt 2000 sóval kapcsolatos királyi döntést 1476-ban azonban már Beatrix királyné erősítette meg. DL 17804. Ugyanezt a dátumot fogadja el Csánki I. 457; Várnagya a királynéi birtokba kerülés után, 1486-ban „Johannes Munkalius tavernicus reginalis ac castellanus castri”. DF 275861.

${ }^{93}$ Draskóczy 2005. 85-87.; Kenyeres 2004. 1110.
} 
forintot ad Ulászlónak. A zálog addig tart majd, amíg a megállapított zálogösszeg, 20780 forint le nem törlesztődik, olyan módon, hogy Perényi az első évben 3500, az azt követő években pedig 4000 forintot vehet ki magának a birtok jövedelméből. ${ }^{94}$

A zálogidőszak alatt - attól talán nem is teljesen függetlenül - az 1514. évi dekrétum 3. cikkelye a máramarosi mezővárosokat az elidegeníthetetlen királyi birtokok közé sorolta, és innentől erre a későbbiekben is rendszeresen van említés. A listán szerepel még emellett a nyolc tárnokszéki vagy szabad királyi város: Buda, Pozsony, Sopron, Nagyszombat, Kassa, Bártfa, Eperjes és Pest; néhány fontos vagy nagy múltú királyi szabad város, mint Óbuda, Esztergom, Székesfehérvár, Lőcse, Szakolca, Kisszeben, Szeged, Visegrád, Asszonypataka és Kolozsvár, valamint a hét alsó-magyarországi bányaváros. A városok mellett említésre kerülnek az erdélyi szászok a bányákkal és néhány további, fontos uradalom. ${ }^{95}$ Lényeges ugyanakkor megjegyezni, hogy a máramarosi királyi mezővárosok nem precízen, név szerint felsorolva szerepelnek a felsorolásban, hanem csak összefoglalóan, mint a huszti vár tartozékait említik meg őket. Ami mégis a leginkább figyelemre méltó lehet, az, hogy országos viszonylatban ezek az egyedüli mezővárosok a listán. ${ }^{96}$

A máramarosi koronavárosok ezután mindig királyi jövedelemforrásként szerepeltek a forrásokban, így az 1518. évi dekrétum 14. cikkelyében, ${ }^{97}$ vagy az 1519. évi dekrétum 11. cikkelyében. ${ }^{98}$

1516. szeptember 12-én, II. Lajos trónra kerülésével a zálog feltételein módosítottak: Perényi Gábor követelése innentől 10000 forint lett, amiért cserében a kiegyenlítésig a bérlet felét megtarthatta, a másik felét

\footnotetext{
${ }^{94}$ DL 71119. Kiadása Perényi 758. sz.

${ }^{95} \mathrm{CJH}$ 708-709. A felsorolásban a következő fontosabb királyi javak kerülnek még említésre a fenti városok mellett: a kunok és a jászok; a Csepel-sziget; a királyi harmincadok és a sókamarák; a királyi szászok az erdélyi bányákkal és sókamarákkal; az összes erdélyi huszad, század és ötvened, valamint öt királyi vár: Munkács, Diósgyőr, Görgény, Törcsvár és Déva a hozzájuk tartozó uradalmakkal. A törvény szövege összesen 19 várost említ meg. Kubinyi 2006. 58-59.; Kenyeres 2004. 1104-1105. Jóval előtte, 1439-ben viszont, amikor felsorolták az 1437. évi királyi birtokokat és várakat, néhány fontos dolgot kihagytak a felsorolásból, nem is akármiket: a macsói bánság várait, az erdélyi vajda és a székely ispán várait, s emellett Gölnicet és Husztot. Utóbbiak a bányakamaráknak voltak alárendelve, ezért sem szerepelnek a listán. Esetleg azért sem, mert ezek már akkor is teljesen evidens módon elidegeníthetetlenek voltak, még ha csak jóval később is kodifikálták ezt a helyzetet, azaz nem nagyon kellett külön emlegetni elidegeníthetetlen voltukat. Engel 1977. 196.

${ }^{96}$ ",Rivulus dominarum et castrum Huszth, cum quinque civitatibus et fodinis salium." CJH 708. Értelemszerúen a munkácsi és diósgyőri uradalmakba is beleszámított a fejlett Munkács és Diósgyőr mezővárosa is, azonban még csak célzás sem esik ezekre a szövegben.

${ }^{97}$ CJH 760. Itt a huszadokkal és harmincadokkal, ötvenedekkel, az arany- és ezüstbányákkal, a szabad városokkal és a szászokkal együtt a jövedelem szempontjából a kincstartóhoz tartoznak.

${ }^{98} \mathrm{CJH}$ 779. Itt ugyanezekkel együtt szintén a kincstartó kezeli a jövedelmeket.
} 
ugyanakkor Szalkai László váci püspök és királyi kincstartó kezébe kell kiszolgáltatnia. Szalkai és Perényi a kamarákban, a huszti várban, illetve a rónaszéki kastélyban közösen tartanak tiszteket, akik kötelesek elszámolni, a sóhajókat pedig Huszton, Szigeten és Becsen közösen rakják meg és értékesítik. ${ }^{99}$

Az 1518-tól a királyi várak igazgatását - köztük Husztét is a sókamarával - a kincstartó felügyelte. ${ }^{100} 1522$-ben a kamarák Csebi Pogány Zsigmond máramarosi- és kamaraispán kezénél vannak zálogbirtok formájában, de ugyanekkor II. Lajos a prelátusok és bárók hozzájárulásával hitbérként feleségének, Mária királynőnek juttatta azokat. A huszti vár, a sókamarák és az öt város mellett a királynő kezébe jelentős javak kerültek még: köztük voltak a bányavárosok a bányákkal, a zólyomi, a munkácsi, a diósgyőri uradalom, valamint Keve, a Csepel-sziget és Óbuda vára. ${ }^{101}$

1523-ban Mária királyné Ártándi Pál királyi tanácsosnak adja őket bérbe öt év időtartamra, évi 7000 forint készpénzért, valamint 1500 forintnyi sóért. ${ }^{102}$ Ártándi ezzel összefüggésben beregi és máramarosi főispáni címet is szerzett. ${ }^{103} \mathrm{~A}$ mohácsi csata után a terület - az Ártándiak pártváltásával - a királyné kezéből Szapolyai és hívei kezébe került. ${ }^{104}$ A mohácsi csatát megelőző két évtizedben az öt mezőváros többször zálogbirtokost váltott ugyan, de a királyi és királynéi örökjog a birtokban mindvégig fennálltt. ${ }^{105}$

A középkor végéig a huszti uradalmat és a sókamarákat tehát a Bélteki-féle birtoklást, illetve a középkor végi zálogidőszakot leszámítva a nyugodt és kiszámítható királyi, illetve királynéi birtoklás jellemezte, ami alapvetően meghatározta a máramarosi mezővárosok mindennapjait, és előnyös feltételeket teremtett a polgárság számára.

\footnotetext{
${ }^{99}$ DL 71145. Kiadta Perényi 791. sz.

${ }^{100}$ Kenyeres 2004. 1104.

${ }^{101}$ Bátori 45. sz; Wenzel 1880. 237; Kenyeres 2004. 1110-1112.

${ }^{102}$ DL 32598. Kenyeres 2004. 1111. A Jagelló-kori birtoklástörténetet röviden összefoglalja Draskóczy 2005. 86.

${ }^{103}$ Bónis 1969. 21.

${ }^{104}$ Kenyeres 2001. 1353.

105 1492: „oppidum nostrum Huzt” Aragóniai Beatrix 233; 1515: „oppido nostro Zygeth vocato”. DF 212557; 1519: „oppido nostro Zygeth”. DF 212556. stb.
} 


\section{A KOLLEKTÍV PRIVILÉGIUM ÉS A VÁROSOK TOVÁBBI KIVÁLTSÁGAI}

\section{A szőllősi és a máramarosi kiváltságlevél kapcsolata}

A Máramarosban a 14. század elején megfigyelhető folyamatok, azaz a sóbányászat fellendülése, a népességnövekedés, a hospesek beköltözése, valamint a városi fejlődés megindulása a királyi hatalom számára is világos volt. Ennek jeleként 1329. április 26-án I. Károly Visk, Huszt, Técső és Hosszúmező szász és magyar vendégtelepeseinek kiváltságlevelet adományozott. ${ }^{106}$

Az uralkodó indoklása szerint a máramarosi hospesek hủ szolgálatának jutalmául, de leginkább a terméketlen máramarosi rengeteg betelepítéséért adományozta a privilégiumot. Ez alapján is arra következtethetünk, hogy a terület benépesedése viszonylag friss, talán a 13. század legvégére visszanyúló fejlemény volt, szó sem lehet tehát 13. századi jelentősebb mértékű beköltözésről, s így komolyabb mértékű sóbányászatról sem.

\footnotetext{
${ }^{106} \mathrm{~A}$ privilégiumhagyománynak több változata ismert, azonban ezek egyike sem korabeli, hanem fennmaradását tekintve 18-19. századi másolat. 1. Az 1352. évi szigeti kiváltságlevelet, amely a Károly-féle oklevelet első ízben átírja, megerősítette és átírta még I. Lajos (1365 decemberében) és Luxemburgi Zsigmond (1404. június 3. illetve 1435. március 12.). Ez a példány egy 1697. évi hiteles átírásban maradt fenn, amely magában foglal egy 1649. évi és egy 1696. évi évi átírást is. DL 2539; 2. A Károly-féle 1329. évi kiváltságlevelet (az I. Lajos-féle oklevél nélkül) átírta emellett Anna királyné 1504. május 14-i oklevele. Utóbbit átírta I. Ferdinánd 1551-i oklevele, mely 18. századi másolatból ismert. DL 22477; 3. I. Mátyás átíró oklevele fennmaradt még egy ismeretlen hiteleshely (valószínűleg a pozsonyi káptalan: MNL-OL E 162 nr. 462. „P' melléklet; az információért Glück Lászlónak tartozom köszönettel) 1697. évi átírásának 18. századi másolatában. DL 24898; 4. A Károly-féle 1329. évi kiváltságlevél ismert ezen kívül egy Beszterce város levéltárában található 19. századi egyszerü másolatból is. DF 247223; A kváltságlevél szövegét kiadta: Wenzel 1857. 70-72; Már. Dipl. 8-11. és CDH VIII/3. 353-356. Regesztája: Anjou XIII. 202. sz. A privilégiumokat részletezi Györffy IV. 125-126. Az oklevél fennmaradására lásd még Glück 2013. 76. 212. jegyzet. Tartalmát részben ismerteti Uö. uo. 76-78.
} 
Az oklevélben ugyan konkrétan nem esik szó ilyenről, de azért felvethető, hogy az egy évtizeddel azelőtti, Mojs elleni hadjáratban a máramarosi telepesek által szerzett hadi érdemek is szerepet játszhattak a kiváltságlevél elnyerésében. ${ }^{107} \mathrm{Az}$ oklevél bevezetője szerint a privilégium a szőllősi kiváltságok mintájára került kiadásra. Ezt a helytörténeti irodalom is rendszeresen hangsúlyozza.

Már a kiváltságolás módja is figyelemreméltó. Kollektív privilégiumot ugyanis a legtöbb esetben nem városi, csak falusi hospesközösségek kaptak, s ennél a pontnál elég csak a fentebb ismertetett ugocsai hospestelepülések kollektív kiváltságára utalnunk. ${ }^{108}$ Ha figyelembe vesszük azt is, hogy a kiváltságlevélben a máramarosi városok nem kapták meg az uralkodótól a legfőbb ügyekben való önálló döntési jogot, akkor már az elején ki kell jelentenünk, hogy a koronavárosok kiváltsága nem érte el a klaszikus értelemben vett városkiváltságok szintjét, gyakorlatilag csupán egy viszonylag széles körű hospeskiváltságról van szó, ami persze önmagában még nem akadálya a későbbi városi fejlődés kibontakozásának. ${ }^{109}$

A magyarországi kiváltságolások második hullámában adományozott máramarosi kollektív privilégium részletesen szabályozta a települések jogéletét. A rendelkezések egy csoportja a máshol is gyakorta szereplő pontokat, jogi, gazdasági és egyházi kiváltságokat foglalta össze, míg néhány a speciális helyi consuetudót, illetve a sajátos máramarosi gazdasági és társadalmi viszonyokat tükrözte. A kiváltságlevél mintájául a már említett szőllősi privilégium szolgált. ${ }^{110}$

Még ha az oklevél nem is tesz róla említést, a szokásnak megfelelően minden bizonnyal itt is maguk a lakók folyamodhattak a királyhoz a privilégiumért, és ehhez a szőllősi jogokat vették mintául, hivatkozási alapul.

${ }^{107}$ DL 2539. „specialiter pro eo, quod terra Marmarusiensis infertilis, laboriosa et gravis ad residendum fore dignoscitur". A lázadó Mojs leverésére indított 1319. évi hadjáratra és a hospesek részvételére lásd Kristó 2003. 324.

${ }^{108}$ A városkiváltságokra a középkor vonatkozásában lásd Fügedi 1981. Újabban, az eddigi szakirodalom összefoglalásával: Szende K. 2011. Az Árpád-korból fennmaradt hospes- és városprivilégiumok listáját lásd uo. 47-48.

${ }^{109}$ A később nagy jelentőségüvé vált Kassa fejlődése sem városi kiváltságlevéllel, csupán egy egyszerü hospeskiváltsággal vette kezdetét, mégis a magyar városok csúcsát jelentő szabad királyi városok csoportjába jutott a 15. századra. Fügedi 1981. 238-239. De városi közösségek ideális körülmények között akár kvázi „földesúri” joghatóság alatt élő soltésztelepekből is kialakulhattak. Gulyás 2013. 330. Ha a városfejlődés bizonyos feltételei (így például a kereskedelmi szempontól megfelelő fekvés vagy a tartós királyi birtoklét) teljesültek egy település története során, akkor a későbbiekben sokszor a városi kiváltságot is sikerült megszerezni. Ha nem voltak megfelelő településfejlesztő tényezők, a legfejlettebb városprivilégium sem eredményezhette a városfejlődés igazán magas fokát, s ezek a települések előbb-utóbb egyszerü mezővárossá váltak.

${ }^{110}$ Ahogy az oklevél fogalmaz: „omnes libertates, quibus cives seu hospites de Szeuleus gaudent et fruuntur" kapják meg a máramarosiak. CDH VIII/3. 353. 
A Tisza-völgyben ugyanis ez volt a hozzájuk legközelebb eső, németek által is lakott, város módjára kiváltságolt település, amelynek ezért többékevésbé jól ismerhették a belső jogviszonyait. Persze az sem kizárt, hogy Máramaros szászok és magyarok általi benépesítésében Szőllős egyfajta „ugródeszka" szerepet játszhatott, hiszen - ahogy arról fentebb már volt szó - a beköltözők nagyrészt éppen Ugocsa felől érkeztek a területre, s ebben az esetben magukkal is hozhatták a szőllősi privilégiumot, pontosabban az annak elnyerésére törekvés igényét. ${ }^{111}$ Tájékozottságuk tehát egyáltalán nem véletlen: bizonyosan ismerték a szőllősiek kiváltságlevelét. Az ezzel a korábbi oklevéllel párhuzamba állítható pontok jelenthetik a privilégium rendelkezéseinek „,alaprétegét”. Meg kell azonban jegyezni, hogy legtöbbjük egyáltalán nem számított kuriózumnak: máshol is a városi jogok legfontosabb csoportját alkották.

Ilyen alapvető, mindkét kiváltságlevélben szereplő rendelkezés volt, hogy a négy helységbe az országos szokás szerint bármely szabad állapotú ember beköltözhetett, és a földbér lefizetésével, valamint az engedély elnyerésével, értékeivel együtt fényes nappal szabadon távozhatott. ${ }^{112} \mathrm{~A}$ királyi hatalom mindkét helyen kivette a lakókat az ispáni joghatóság alól, ehelyett a közösség által választott (illetve Máramarosban még a király által kijelölt) bíró ítélhetett felettük, ezenkívül viszont semmilyen ispán bíráskodása alá nem tartoztak. ${ }^{113}$

${ }^{111} \mathrm{Az}$ mindenesetre kijelenthető, hogy a szőllősi és huszti hospesek között a 14. század közepén szoros kapcsolat lehetett. 1351 augusztusában például a Bilkeiek oldalán kéz a kézben hatalmaskodnak az Újhelyi-birtokokon. DL 38161. A részvevők: „hospites de Zeuleus et de Husthy". 1514-ben pedig egy Husztról Szőllősre költöző polgárról van adatunk („Item quandam domum in predicto oppido suo Zewlews in qua alias quidam Ladislaus Zyws de Hwzth inhabitasset"). DL 71132. stb. A későbbiekben látjuk majd, hogy a helyi bíráskodás terén is volt köztük együttmüködés.

${ }^{112}$ A rendelkezés így szól: „quod quicunque conditionis liberae homines ad villas praedictas causa commorandi venire voluerint, libere veniant et secure commorentur et sicut libere veniunt, sic et libere alias quocunque voluerint se conferre possint cum rebus ipsorum et personis, venditis aedificiis propriis sumptibus comparatis soluto iusto et consueto terragio, habitaque licentia de villa abeundi clara luce." CDH VIII/3. 353. Ugyanez a rendelkezés Szőllős esetében: „quod quicunque homines libere conditionis ad villam Zeleus causa commorandi venire voluerint secure veniant et libere commorentur, et sicut libere veniunt sic et libere recedere possint salvis rebus ipsorum et personis, venditis edificiis propriis sumptibus conparatis, soluto iusto terragio, habita licencia de villico clara luce." ÁÚO VIII. 31-32. A továbbiakban a két kiváltságlevelet mindig a jelzett forrásközlésekből idézzük, ezért azokat külön már nem hivatkozzuk le. A jobbágyköltözés feltételei (tartozások és a terragium megfizetése, engedély elnyerése) a 14. századra már többé-kevésbé megszilárdultak Magyarországon. Kring 1935; Szabó I. 1954; Solymosi 1972; Solymosi 1994. Adataink szerint a máramarosi polgárok a koraújkorban is éltek ezzel a jogukkal. Glück 2013. 72., 213. jegyzet.

${ }^{113}$ Máramaros: „Secundo item quod iudicio nullius comitis stare teneantur, nisi iudicis ipsorum per nos deputati, aut villici ipsorum per communitatem electi.” és „Szőllős: „Item quod iudicio nullius comitis astare teneantur, nisi iudicis aut villici ex communitate electi." Szó sincs arról - ami a helytörténeti irodalomban rendszeresen előkerül - hogy a települé- 
Ami azonban az egyik legfontosabb és legárulkodóbb eleme a máramarosi négy hospestelep privilégiumának: a bíró és az „idősek tanácsa” minden egymás közötti ügyben illetékesek ugyan, de nem ítélhetnek önállóan a nagyobb ügyekben, azaz emberölés, erőszak, lopás és gyújtogatás alkalmával. Ilyen esetekben a helyi bíró csak a király bírájával együtt dönthetett, a bírságpénzeken pedig 1/3-2/3 arányban osztozkodtak. A szőllősieknél az oklevél nem tesz ilyen kitételt. Emellett mindkét oklevél kimondja azt is, hogy a közösségen belül keletkezett perekben a telepesek szabadon megegyezhetnek. ${ }^{114}$

A legfőbb ügyekben való ítélkezés jogának birtoklása fontos választóvonal volt a városi jogok szempontjából: a „valódi” városok általában ítélhettek ezekben az ügyekben, a hétköznapi hospestelepülések azonban nem. ${ }^{115}$ Mivel az ilyen esetekben a máramarosi kiváltságlevél megosztotta a joghatóságot, nagyon óvatosan kell akkor fogalmaznunk, amikor a kiváltságok minőségét próbáljuk meghatározni. Ha erről az oldalról tekintünk a privilégiumra, meg kell állapítanunk, hogy ez alapján közelebb állt a hospeskiváltságok szintjéhez, mint a városkiváltságokhoz.

A máramarosiak és a szőllősiek az általános gyakorlat alapján a bíró mellett a papot is maguk választhatták, utóbbit határozatlan időre. Az 1329. évi rendelkezésben a király a választott plébánosnak azt a jogát is kikötötte, hogy javaival szabadon rendelkezhet és azokat élete végén örökítheti, míg Szőllősön a végrendelkezés kérdéséről szó sem esik. ${ }^{116}$

Kevésbé gyakori az az oklevélben rögzített szokás, miszerint a papnak járó tizedet itt is és ott is a mezőn hagyhatták, azaz a lakosok mentesültek az ezzel kapcsolatos szállítási feladatoktól. Ez alapján a libera decima jogával is bírtak, azaz a tizedet a saját papjuknak fizették. Itt a máramarosi

seknek két vezetője lett volna, a „bíró és a majoros”. A villicus jelentése a 14. századi városias településeken köztudottan a iudex-szel egyenértékü, annak archaikusabb formája és csupán a 15. századra jelent egyértelmúen „falunagyot”. Igyártó 2005. 21.

${ }^{114}$ Máramaros: „Octavo item volumus, ut omnes causas inter ipsos motas et movendas villicus eorum cum senioribus ipsorum possit iudicare, exceptis homicidio, violentia, furto et incendio quas iudex noster cum villico ipsorum iudicabit. Quarum causarum iudicatarum duas partes iudex noster percipiet, tertia parte villico eorum remanente." Az 1329. évi kiváltságlevél idézett kiadásából és 18. századi átírásából is hiányzik a rendelkezések kilencedik, ide vonatkozó pontja, azonban ez megtalálható az oklevél 1696. évi átírásában: „Nono item super causis inter ipsos exactis liberam habeant pacem reformandi facultatem." DL 22477. Szőllős: „Item super causis inter se exortis liberare habeant pacem reformandi facultatem."

115 Solymosi 1998. 8-9.

${ }^{116}$ Máramaros: „Tertio item villicum inter se eligant quem voluerint de communi voluntate, et sacerdotem seu plebanum ad ecclesias eorum parochiales sponte recipiant, quem in iisdem ecclesiis non solum usque tempus, sed etiam perpetuo possint conservare, et idem plebanus eorum in suis extremis bona sua et res suas liberam habeat quibuscunque voluerit legandi facultatem." Szőllős: „Item villicum inter se eligant quem voluerint, et sacerdotem sponte recipiant." 
hospesek számára a mintát egyértelműen a hasonlóan fogalmazó szőllősi rendelkezés jelenthette, azt szinte automatikusan vette át a Károly Róbertféle oklevél. ${ }^{117}$

Eltérés van azonban a helyi pap által a püspöknek fizetendő dézsma összege között: Máramarosban a papok minden ötven, szántóval is rendelkező telek után tizedként egy dénármárkát fizetnek a szokásos időpontban, míg Szőllősön a fizetendő összeg együttesen, azaz a teljes közösségre nézvést volt egy márka. ${ }^{118} \mathrm{~A}$ két megoldás közül tehát a szőllősi a kedvezőbb, hiszen ott a rögzített fizetési összeg a lakosság növekedésével egyre kedvezőbbé vált, és egyre kevesebb fizetnivalót jelentett a pap számára.

Mindkét privilégiumban tiltják, hogy a bárók descensust vegyenek rajtuk. ${ }^{119} \mathrm{~A}$ vérdíjakkal kapcsolatos rendelkezés szintén rokonságot mutat a szőllősi hospesek kiváltságával. Máramarosban az emberölésért fizetendő vérdíj 2 márka, halálos seb okozásakor 1 márka, bántalmazásért fél márka, vérontás nélküli bántalmazásért pedig 60 dénár. Káromlásért az oklevél kikötése szerint a kártérítés nem lehetett ennél a 60 dénárnál magasabb. Szőllősön a vérdíj pontosan ugyanennyi volt, azzal a különbséggel, hogy nem tettek különbséget a vér hullásával járó, illetve anélküli bántalmazás között, amelyek egyaránt félmárkányi vérdíj fizetését vonják maguk után, és a becsületsértést sem szankcionálták. ${ }^{120}$

${ }^{117}$ Máramaros: „Quarto item iidem hospites nostri decimam sacerdoti seu plebano debitam in agro relinquant ex integro.” Szőllős: „Item decimam sacerdoti debitam in agro relinquant."

${ }^{118}$ Máramaros: „Quinto item sacerdotes eorum de quinquaginta fundis integris terras arabiles habentibus ratione decimarum solvant suo episcopo dioecesano unam marcam denariorum tempore currentium in termino consueto." Szőllős: „Item sacerdos eorum de omnibus mansionibus ratione decimarum solvat nobis, vel cui nos preceperimus unam marcam in termino assignato." Az anjou-kori oklevéltár meglehetősen bizonytalanul értelmezi a szöveget: „papjuknak a tizedek alapján minden 50 [hold?] szántófölddel rendelkező egész telek után 1 márkát kell a szokott időben s a mindenkori árfolyamon a megyéspüspököknek megfizetniük". Pedig az oklevél egyértelmüen fogalmaz és szó sincs benne hasonlókról. Anjou XIII. 202. sz. Egyébként, ha esetleg kétségeink lennének, a szöveget ugyanígy fordítja a kiváltságlevélnek és megújításainak 18. század közepén készült magyar nyelvű változata is. Közli: Szöllősy 1994. 40.

119 Máramaros: „Decimo quarto: „Item volumus, quod nullus baronum nostrorum super eos descensum facere praesumat violentum.” Szőllo”s: „Volumus etiam, quod nullus baronum nostrorum super eos descensum facere presumpmat violentum."

${ }^{120}$ Máramaros: „Sexto item homicida pro homicidy iudicio solvat duas marcas denariorum. Septimo item pro mortali vulnere unam marcam, et de percussione quae fit cum sanguinis effusione dimidiam marcam. De simplici percussione absque sanguine, sexaginta denarios solvat reus. De vituperio autem nihil plus quaeratur per vituperatum nisi facto." Szőllős: „Item omicida pro omicidio iudici eorum solvet duas marcas. Item pro mortali vulnere unam marcam et de simplici percussione sine sit cum sanguine, sive non, dimidiam marcam." 
Máramarosban a rendelkezés szerint terragium gyanánt a hospesek egész telkenként fél fertót (azaz 6 pondust) fizettek, míg a szántóföld nélküli telkek esetében ez ennek a fele, 3 pondus volt. Szőllősön a szántókkal rendelkező telkekért évente 3 pondust, a szántóföldek nélküliért pedig csupán másfelet. A fizetés mind a két esetben Szent Mártonkor (november 11.) történt, az adó begyüjtését és elküldését Szőllősön a bíró és a pap közösen végezte. ${ }^{121}$ Azaz sem Szőllősön, sem Máramarosban nem a legkedvezőbbnek tekinthető kollektív fizetés módszerével határozták meg a földbér összegét, ${ }^{122}$ hanem telkenként szabták azt ki, de a kettő közül mégis csak a szőllősiek jártak jobban, hiszen alapesetben is feleakkora volt csupán a fizetnivalójuk, mint a koronavárosok lakosainak, míg a szántók nélküli telkek birtokosai csak a máramarosi összeg negyedét adózták. A 15. századból a mezővárosok rendkívüli adójáról is rendelkezünk adattal. 1470-ben az öt mezőváros subsidiumát Mátyás 1 forint helyett 60 dénárra szállította le, cserében a maradék 40 dénár értékében a polgárok szekerekkel voltak kötelesek szolgálni a kamarispánnak. ${ }^{123}$ Nyilvánvalóan a kamara igényeinek kielégítése, egészen konkrétan a sószállítás ügye állhat a dolog hátterében.

Az adót a 15. században a máramarosi mezővárosok már bizonyosan egy összegben továbbították a kincstárba. 1456-ban ugyanis Hunyadi János kormányzó közbenjárására Hosszúmező polgárai a település elpusztulása miatt és a lakosság számának növelése érdekében azt az engedményt kapják, hogy rendes és rendkívüli adójukat ne a técsőiekkel közösen, hanem külön, a porták száma alapján (iuxta numerum portarum suarum) fizessék. A király mind a megyét, mind a többi négy várost tiltja ettől az aránytalan adóbeszedéstől. ${ }^{124}$ Ez egyértelműen arra utal, hogy ugyan az adó kivetésének alapja a király szemszögéből nézve valóban az összesített portaszám volt, de azt az öt városon belül nem teljesen a valós portaszám alapján oszthatták el, ami viszont a kisebb mezővárosok számára hátrányos volt.

\footnotetext{
${ }^{121}$ Máramaros:" Undecimo praeterea ipsi hospites nostri pro terragio de singulis fundis integris singulos dimidios fertones singulis festivitatibus Beati Martini Confessoris nobis dare et solvere teneantur." és „Hoc non praetermisso, quod de singulis curiis sive fundis agros non habentibus nonnisi tria pondera pro terragio nobis solvere teneantur." Szőllős: „Item de singulis curiis habentibus agros annuatim solvent tria pondera, et de singulis curiis agros non habentibus unum pondus et dimidium." illetve „Volumus etiam, quod terragium villicus eorum et sacerdos circa festum Sancti Martini colligant, et iidem nobis deferant."

${ }^{122}$ Adózás szempontjából a legjobb helyzetben azok a települések voltak, ahol nem telkenként vagy fejenként, hanem kollektíven szabták ki a földbért, hiszen így a közösség saját maga róhatta ki tagjaira a teherbíró képesség figyelembe vételével a terheket, másrészt, ha a lakosság száma növekedett, az egy főre eső fizetnivaló is csökkent. Mályusz 1953. 151.

${ }^{123}$ Draskóczy 2005. 92.

${ }^{124}$ DF 247899. A kiváltságért Nyerges Tamás bíró és Dyak Miklós esküdtek folyamodtak. 1459-ben szintén Dyak Miklós esküdt kérésére a kiváltságot I. Mátyás is megerősítette. DF 247907.
} 
A kora újkorból további információink is vannak a tartozásokra nézve. A 16-17. század fordulójáról az 1600. és 1614. évi urbáriumok alapján az öt mezőváros egy összegben, a telekszámtól függetlenül összesen 1100 forintnyi adót fizetett, robot nem terhelte őket, csak az uradalom körül ellenszolgáltatásért elvégzendő kötelező munkaszolgálat (így a vár karbantartása, bor-, gabona- és sószállítás), melyért sóval fizettek nekik a tiszttartók. ${ }^{125}$

A kereskedelmi kiváltságok mindkét helyen ugyanúgy alakultak: a hospesek itt is és ott is szabadon kereskedhettek áruikkal, ezzel kapcsolatos ügyekben pedig maguk ítélkezhettek, bár a máramarosi hospesekkel kapcsolatban a királyi hatalom azt is kikötötte, hogy amennyiben az ilyen ügyekben történő jogszolgáltatást elhanyagolnák, akkor az érintett javak az idegen hitelező által tilalom alá vonhatók. ${ }^{126}$ A hospesek a vámmentes hetivásár rendezésének jogát szintén megkapták. ${ }^{127}$ A szőllősieknek azonban ezen a téren is kicsivel több jutott, holott a kérdésben a szintén a Tisza mellett fekvő máramarosi városok is érdekeltek lettek volna: ők ugyanis a település mellett tiszai révet, és helységükön keresztül „szabad utat” is kaptak a kereskedésre. ${ }^{128}$ Máramarosban ilyenekről nem esik említés.

Az utolsó olyan pontja a két privilégiumnak, amelyek párhuzamot mutatnak, a különféle, a lakosság által folytatott beruházásokkal állnak kapcsolatban. A frissiben megtelepedett máramarosiak építkezési engedélyt, illetve új termőföldek létrehozásának lehetőségét, a szőllősiek pedig malom- és szőlőalapítási lehetőséget kaptak. ${ }^{129}$

Eddig azt láttuk tehát, hogy a legfontosabb kiváltságok tekintetében a két privilégium nagyjából hasonlóan járt el, tehát egyértelmü, hogy a szőllősi kiváltságlevélre hivatkozás nem csupán lózung volt, hanem annak tartalmát valóban pontosan ismerhették és figyelembe vehették a kiváltságolás során. Az eltérések azonban mindig a máramarosi koronavárosok

\footnotetext{
${ }^{125}$ Glück 2013. 81-83.

${ }^{126}$ Máramaros: „Duodecimo volumus etiam, quod ubicunque processerint cum suis mercimoniis, nullus eosdem praesumat impedire, sed si qui aliquid actionis habuerint contra ipsos, coram iudice vel villico eorumdem ordine iudiciario prosequatur, et si in reddenda querulantibus iustitia is contumax fuerit, tandem possint prohibere bona eorumdem." Szőllős: „Item volumus, quod ubicunque fuerint cum suis mercimoniis, nullas eosdem presumpmat inpedire, sed si aliquis aliquid actionis habuerit contra eosdem, coram villico eorum ordine iudiciario prosequatur."

${ }^{127}$ Máramaros: „Decimo tertio item volumus, quod fora habita in eisdem villis sub constitutis diebus libere et absque tributo aliquali celebrentur.” Szőllős: „Item volumus, quod forum habeant liberum et absque tributo secunda feria celebrandum."

128 "Item portum super Ticiam habeant iuxta eandem villam et via currat libera per medium ville supradicte." Ez persze nem zárja ki annak lehetőségét, hogy a későbbiekben a városok külön-külön szerezhettek hasonló kiváltságokat, még ha adatunk nincs is erre nézve.

${ }^{129}$ Máramaros: „Decimo quinto et etiam si voluerint aliqua opera utilia et novas plantationes liberam habeant faciendi facultatem." Szőllős: „Item, si qui voluerint molendina et alia opera utilia ac vineas liberam habeant faciendi facultatem."
} 
esetében voltak szűkmarkúbbak: az ifjabb István király-féle rendelkezésből Károly Róbert újra és újra lecsippentett valamit az 1329. évi kiváltságoláskor. Ráadásul a két privilégium néhány pontban teljesen különbözik egymástól, s ezek a különbségek általában szintén a máramarosiakat sújtják.

A legfontosabb ezek közül, hogy a szőllősiek megkapták a város területére vonatkozó halászati és vadászati jogot, illetve ráadásként birtokot is szereztek, a szomszédos Darócot a hozzá tartozó halászóhellyel. Az 1329. évi rendelkezésben azonban sem az előbbi kiváltság nem szerepel, sem pedig birtokkal nem látta el a máramarosi hospeseket a király. ${ }^{130}$ Igaz, nekik legalább nem kellett egy teljes felszereltségü katonát küldeniük a királyi seregbe, mint amire a szőllősiek kénytelenek voltak. ${ }^{131}$ A Károly Róbertféle oklevélnek két olyan pontja van viszont, amely nem szerepel a szőllösiben, s amely a helyi gazdasági és földrajzi, illetve társadalmi viszonyoknak az eredménye volt.

Az egyik a helyi természetföldrajzi körülményekből adódik. Ahogy az oklevél fogalmaz, a máramarosi föld terméketlensége miatt a hospesek a rossz termés miatt mentesek voltak a gabonaakók és a sertéstizedek alól, valamint a különféle ajándékok adásának kötelezettségétől. ${ }^{132}$

A másik annak a tilalma, hogy az irtásra előzetesen lefoglalt földeket más nyelvűek vagy nemzetiségúek elvegyék a hospesektől, ami egyértelmúen a Máramarosban ekkoriban megjelenő vlahok ellen irányuló utasításnak tekinthető. ${ }^{133} \mathrm{~A}$ félelem nem volt indokolatlan, ugyanis, ahogyan azt látni fogjuk, a koronavárosoknak később is többször meggyưlt a bajuk a szomszédos román birtokosokkal.

Ellentétük láthatólag alapvetően birtokjogi jellegü volt, és határvitákban, olykor pedig súlyos hatalmaskodásban realizálódott. Ilyen vlah eredetű szomszédokkal rendelkezett például Técső (Bedő), Hosszúmező (Szarvaszó és Szaplonca), és Sziget is (Farkasfalva, Bárdfalva és Váncsfalva). ${ }^{134}$

\footnotetext{
${ }^{130}$ A szőllősi rendelkezések ide vágó részei: „Concessimus etiam, quod in silvis adiacentibus venari capriolos, lupos, wlpes et in aquis piscari libere possint et secure." illetve „Preterea, ut numerus hospitum nobis serviencium augeatur, dedimus terram Droch, et terram piscatorum nostrorum adiacentem eisdem."

${ }^{131}$ „Item ad nostrum exercitum in quo esse debemus personaliter unum militem cum armis militaribus mittere tenebuntur." A katonaállítási kötelezettség előírása a 13. század közepén gyakori jelenség volt, a tatárjárás utáni királyi hadügypolitika alapvető elemét jelentette.

132 „Decimo septimo item, quia ipsa terra Maramurusiensis multum sterilis esse dicitur ut est praedictum, pro persolutione akonum frugum, decimarum porcorum, et oblationibus munerum alias praesentare et offerre consuetorum, propter carentiam annonae ipsos prius reddidimus liberos et pariter expeditos."

133 "Decimo statuimus etiam, ut terras eorum, quas ipsi stirpando praeoccupasse dicuntur labores eorum expendendo pro eisdem, nullius idiomatis vel nationis homines ipsas terras ab ipsis auferendi habeant facultatem."

${ }^{134}$ Már. Dipl. 13-16., 69-70., 178-180.
} 
A privilégium legfontosabb konklúziója az, hogy ugyan a máramarosi hospesek ismervén a szőllősiek kiváltságait és kedvező helyzetét, ugyanazt a szabályozást kérhették az uralkodótól, mint bő hatvan évvel azelőtt a szomszédvár telepesei, ehelyett azonban mégis mást kaptak. A szőllősi kiváltságok közül szinte csak a legáltalánosabb dolgokat foglaltatta bele a király a jogaik felsorolásába, azokat is általában kevésbé kedvező módon, néhány fontos pontot pedig egészen egyszerűen kihagyott. Ennek oka részben a városiasodás eltérő mértéke lehetett: a nem sokkal korábban létrejött máramarosi négy város az Anjou-kor első felében még nyilvánvalóan a fejlődés alacsonyabb szintjén állhatott, mint a 13. századi kiváltság elnyerésekor a szőllősiek. Úgy látszik ekkor még csak nem igazán jelentős hospestelepüléseknek számíthattak.

Másrészt, az sem mindegy, hogy mikor történt a kiváltságolás. Alig pár év telt el ugyanis azóta, hogy Károly Róbert Csák Máté halálával kiterjeszthette hatalmát az ország területének legnagyobb részére. Ezeket az éveket pedig az uralkodó köztudottan a királyi hatalom anyagi alapjainak megerősítésére, az államháztartás hosszan elhúzódó és sokáig formálódó reformjára fordította. Ekkor indulnak a nagy gazdasági és pénzügyi intézkedések, amelyek a regálebevételek megerősítését szolgálják, és ekkor indul meg a domaniális jövedelmek újraszervezése is. ${ }^{135}$

Egy ilyen korszakban a sóbányákból várható tekintélyes jövedelem stratégiai jelentősége miatt I. Károly nem akart tehát teljesen lemondani a települések feletti joghatóságáról, hanem arra törekedett, hogy a térség, s ezzel a sólelőhelyek feletti fennhatóságát és viszonylag közvetlen befolyását szilárdan fenntarthassa. Éppen ezért, a széles körü szabadságokat magában foglaló szőllősi kiváltságlevél teljes mértékű adaptálása szóba sem jöhetett. Ennek az eredménye lett ez a némileg „felemás" módon kivitelezett kiváltságolás, amely szorosabb függést (a király részéről közvetlen beavatkozási lehetőséget), magasabb terragiumot és így több bevételt eredményezett a számára.

${ }^{135} \mathrm{Az}$ ezt nem sokkal megelőző időszakot részletesen tárgyalja Engel 1988. A gazdasági intézkedésekre: Hómann 1921. 


\begin{tabular}{|c|c|c|c|c|}
\hline Privilégium & \multicolumn{2}{|c|}{ Szőllős (1262) } & \multicolumn{2}{|c|}{ Máramaros $(1329,1352)$} \\
\hline \multicolumn{5}{|c|}{ Jogi kiváltságok } \\
\hline $\begin{array}{l}\text { költözési } \\
\text { szabadság }\end{array}$ & \multicolumn{2}{|l|}{ igen } & \multicolumn{2}{|l|}{ igen } \\
\hline $\begin{array}{l}\text { ispáni } \\
\text { joghatóság } \\
\text { alóli kivétel }\end{array}$ & \multicolumn{2}{|l|}{ igen } & \multicolumn{2}{|l|}{ igen } \\
\hline descensus tiltása & \multicolumn{2}{|l|}{ igen } & \multicolumn{2}{|l|}{ igen } \\
\hline bíróválasztás & \multicolumn{2}{|c|}{ a közösség választja } & \multicolumn{2}{|c|}{$\begin{array}{l}\text { a közösség választja, vagy az } \\
\text { uralkodó jelöli ki }\end{array}$} \\
\hline bírói hatáskör & \multicolumn{2}{|c|}{$\begin{array}{l}\text { kisebb és nagyobb ügyek- } \\
\text { ben, illetve a kereskedelmi } \\
\text { ügyekben }\end{array}$} & \multicolumn{2}{|c|}{$\begin{array}{l}\text { csak a kisebb és a kereskedel- } \\
\text { mi ügyekben, a nagyobbakban } \\
\text { a király bírájával közösen ítél }\end{array}$} \\
\hline $\begin{array}{l}\text { perbeli szabad } \\
\text { megegyezés } \\
\text { lehetősége }\end{array}$ & \multicolumn{2}{|l|}{ igen } & \multicolumn{2}{|c|}{ igen } \\
\hline \multirow{5}{*}{ vérdíj összege } & emberölés & 2 márka & emberölés & 2 márka \\
\hline & halálos seb & 1 márka & halálos seb & 1 márka \\
\hline & vérontás & $1 / 2$ márka & vérontás & $1 / 2$ márka \\
\hline & bántalmazás & $1 / 2$ márka & bántalmazás & 60 dénár \\
\hline & becsületsértés & nem említi & becsületsértés & $=<60$ dénár \\
\hline \multicolumn{5}{|c|}{ Egyházi kiváltságok } \\
\hline papválasztás & \multicolumn{2}{|c|}{ a közösség választja } & \multicolumn{2}{|c|}{ a közösség választja } \\
\hline libera decima & \multicolumn{2}{|c|}{ igen } & \multicolumn{2}{|c|}{ igen } \\
\hline $\begin{array}{l}\text { tizedfizetés } \\
\text { módja }\end{array}$ & \multicolumn{2}{|c|}{$\begin{array}{l}\text { a lakosság a mezőn } \\
\text { hagyhatja }\end{array}$} & \multicolumn{2}{|c|}{ a lakosság a mezőn hagyhatja } \\
\hline tized összege & \multicolumn{2}{|c|}{ összesen 1 márka } & \multicolumn{2}{|c|}{$\begin{array}{l}\text { minden, szántóval bíró } 50 \text { telek } \\
\text { után } 1 \text { márka }\end{array}$} \\
\hline \multicolumn{5}{|c|}{ Gazdasági kiváltságok } \\
\hline $\begin{array}{l}\text { kereskedelem } \\
\text { védelme }\end{array}$ & \multicolumn{2}{|l|}{ igen } & \multicolumn{2}{|l|}{ igen } \\
\hline forum liberum & \multicolumn{2}{|l|}{ igen } & \multicolumn{2}{|l|}{ igen } \\
\hline $\begin{array}{l}\text { kereskedelmi } \\
\text { út biztosítása }\end{array}$ & \multicolumn{2}{|c|}{$\begin{array}{l}\text { a tiszai rév és a településen } \\
\text { áthaladó út szabad haszná- } \\
\text { lata }\end{array}$} & \multicolumn{2}{|l|}{ nem említ ilyet } \\
\hline
\end{tabular}




\begin{tabular}{|c|c|c|c|c|}
\hline $\begin{array}{l}\text { beruházások } \\
\text { engedélyezése }\end{array}$ & \multicolumn{2}{|c|}{ malom- és szőlőalapítás } & \multicolumn{2}{|c|}{$\begin{array}{l}\text { építkezés, szántó létrehozása } \\
\text { irtással, az irtandó földeket } \\
\text { nem vehetik el tőlük }\end{array}$} \\
\hline $\begin{array}{l}\text { terület és } \\
\text { haszonvételek } \\
\text { átadása }\end{array}$ & \multicolumn{2}{|l|}{ igen } & \multicolumn{2}{|c|}{ nem említ ilyet } \\
\hline \multicolumn{5}{|c|}{ A lakosság szolgáltatásai } \\
\hline $\begin{array}{l}\text { terragiumfizetés } \\
\text { időpontja }\end{array}$ & \multicolumn{2}{|c|}{ Szent Márton (nov. 11.) } & \multicolumn{2}{|c|}{ Szent Márton (nov. 11.) } \\
\hline \multirow{2}{*}{$\begin{array}{l}\text { terragium } \\
\text { összege }\end{array}$} & egész telek & 3 pondus & egész telek & 6 pondus \\
\hline & $\begin{array}{l}\text { szántó nélküli } \\
\text { telek }\end{array}$ & 1,5 pondus & $\begin{array}{l}\text { szántó nélküli } \\
\text { telek }\end{array}$ & 3 pondus \\
\hline $\begin{array}{l}\text { katonaállítási } \\
\text { kötelezettség }\end{array}$ & \multicolumn{2}{|c|}{1 teljes fegyverzetü } & \multicolumn{2}{|l|}{ nem említ ilyet } \\
\hline adómentesség & \multicolumn{2}{|l|}{ nem említ ilyet } & \multicolumn{2}{|c|}{$\begin{array}{l}\text { a rossz termés miatt állandó } \\
\text { felmentés a terményadók alól }\end{array}$} \\
\hline
\end{tabular}

\section{A kiváltságlevelek megújításai és a kiváltságok kibővítései}

A kiváltságlevél 1329 után akkor került újra elő, amikor 1352. február 18-án rendelkezéseit a szigeti hospesekre is kiterjesztették. Ekkor I. Lajos király a négy város nevében megjelenő Miklós fia Ferenc viski hospes és az oklevél rongálódása miatt olvashatatlan nevü huszti villicus kívánságára átírta és megerősítette apja rendelkezését, illetve - miután a szigeti Szent Imre egyház plébánosa Benedek, valamint az ugyanottani királyi jobbágyok ezt kérték tőle - a privilégium pontjait Sziget városára is kiterjesztette, mégpedig következetes módon mindenféle változtatás nélkül. Ugyanő 1365 végén az oklevelet a királyi nagypecsét elvesztése miatt újonnan vésetett pecsétjével hitelesítette és megerósítette. ${ }^{136}$

${ }^{136}$ DL 2539: „Franciscus filius Nicolai hospes de Visk et --- filius --- villicus de Hust in eorum et universorum hospitum seu iobagionum nostrorum Saxonum et Hungarorum in predictis villis Visk, Hust, Técsö et Hosszumezö vocatis in Maromorusio... nominibus et in personis exhibuerunt nobis et presentaverunt" Károly oklevelét a hospesek „super libertatibus ipsorum per eundem dominum Karolum regem datas et concessas tenore infrascripti, supplicantes iidem humiliter", hogy azt hiteles oklevélbe írja át. Illetve, miután „discreti viri Benedicti plebani ecclesiae Sancti Emerici confessoris de Szigeth vice et nominibus universorum populorum seu iobagionum de eadem” alázatosan erre kérte őt, elrendelte, hogy „iidem suprascriptis libertatibus eo modo, sicut populi et hospites prenominatorum villarum nostrarum potiuntur et fruuntur, cum eisdem unanimiter et conformiter sine variatione aliquali perpetuo gratulentur." Az 1365. évi megerősítés átírása ugyanezen a jelzeten található. Lásd még Wenzel 1857. 34. 
1404. június 3-án Luxemburgi Zsigmond újítja meg az 1329-es és 1352es privilégiumot, amikor a szász és magyar hospesek nevében a színe elé járuló László huszti, György viski, Ferenc técsői, illetve a szigeti villicus közösen kérték, hogy hiteles oklevélbe írja át Károly Róbert és Nagy Lajos királyok korábbi kiváltságleveleit. ${ }^{137} 1435$. március 12-án az uralkodó az öt koronaváros képviseletében tőle ezt kérvényező Kethel dictus János, illetve Nagy (magnus) Benedek viski és huszti villicusok közbenjárására ezt a korábbi kiváltságlevelét újfent megerősítette. ${ }^{138}$ 1453-ban V. László felszólította az akkori és a később hivatalban lévő máramarosi ispánokat és alispánokat, hogy a máramarosi mezővárosok lakosságát régi privilégiumuk gyakorlásában ne akadályozzák. ${ }^{139} 1472$. augusztus 2-án I. Mátyás is megerősítette az öt mezővárost összes privilégiumaikban és felszólította Horvát János akkori ispánt, illetve a mindenkori máramarosi ispánokat, hogy tartsák is tiszteletben ezeket. ${ }^{140} \mathrm{~A}$ dolog előzménye a nem sokkal korábbi moldvai betörés volt, amelynek következtében az oklevél elbeszélése szerint a máramarosi mezővárosok sok kárt szenvedtek el. ${ }^{141}$

Simonchiczra hivatkozva Wenzel beszámol emellett egy 1500. évi vámkiváltságról is, azonban az adat bizonytalan, az oklevelet nem sikerült beazonosítanunk. ${ }^{142}$

${ }^{137}$ DL 2539: „fideles nostri viri providi Ladislaus de Hust, Georgius de Visk, Franciscus de Techö, --- de Szigeth villici nostri in suis et universorum hospitum et iobagionum Saxonum et Hungarorum in villis nostris Hust, Visk, Tecsö et Szigeth predictis ac Hosszumezö vocatis in Maromorusio existentibus commorantium personis accedentis in nostra maiestatis in presentiam, exhibuerunt nobis quoddam privilegium inclyti principis domini Lodovici" stb.

${ }^{138}$ DL 2539: Zsigmond tudtul adja, hogy „fideles nostri Joannes dictus Kethel de Visk et Benedictus magnus de Hust villici in eorum et universorum hospitum seu iobagionum Saxonum et Hungarorum in villis nostris Hust et Visk predictis, ac Tecsö, Sziget et Hoszzumezö apellatis in Maramorusio existentibus commorantis personis, exhibuit nobis quasdam literas nostras privilegiales", amely magában foglalta I. Lajos és I. Károly kiváltságleveleinek szövegét is, és kérték a királyt, hogy ezen korábbi, 1404. évi oklevelét írja át.

${ }^{139}$ DF 274893.

${ }^{140}$ Eredetije: DF 275905. Fennmaradt még egy 1696-os, ill. 1753-as átírásban. DL 22477 és DL 24898. Szövegét közli Wenzel 1857. 73. és Hunyadiak kora XI. 479-481.

${ }^{141}$ DL 22477 (kiadása: Már. Dipl. 516-517.). Az előterjesztők: „fidelium nostrorum honorabilis et circumspecti magistri de Szölös, vicarii Joannis Horvath comitis, et Andree Hintzi civium terre Maramorosiensis per eos pro parte ipsorum ac universorum civium et inhabitatorum oppidorum nostrorum Huszt, Szygeth, Hozzumezö ac Visk et Tecsö in terre Maramorosiensis existentium commorantium”. A kérés oka: „combustione ac devastatione... eorundem oppidorum nostrorum, quas superioribus temporibus eadem penes fidelitatem ipsorum mihi observandam per Valachos" és mások által elszenvedtek. A király ezért megerősíti kiváltságaikat, amelyeket kegyes emlékű elődei által már régóta élveztek és ennek betartására ispánjait is felszólítja.

${ }^{142}$ Wenzel 1857. 73. 
1504. május 14-én Anna királyné is oklevelet bocsátott ki a mezővárosok kiváltságai kapcsán, amelynek érdekében egyébként Imre fia Tamás huszti és Szász Lőrinc szigeti bíró járt el nála. Az oklevél néhány újabb rendelkezéssel egészítette ki azokat a kiváltságokat, amelyeket már eddig is említettünk, illetve ezek közül néhány már nyilván korábban is érvényben lehetett, csak a források ezt nem említették. Így a máramarosi polgárok szabadon használhatták a Fekete-erdőt a hozzá tartozó mezőkkel, s abban semmilyen officiális nem gátolhatta meg őket, állataik után tizedet nem fizettek, ${ }^{143}$ javaikat pedig (nyilvánvalóan a különféle módokon szerezhető sókockákon lehet itt elsősorban a hangsúly) Máramaros területéről szabadon kivihették és eladhatták.

A legfontosabb pontjai azonban - amelyek egyébként módosították a korábbi kollektív privilégiumot is - azok voltak, hogy amennyiben az ügy a kamaraispánt nem illette, a gonosztevőket elfoghatták és elítélhették, s szabadon engedésüket a bírón kívül senki sem kezdeményezhette; valamint, hogy a perekkel előbb Szőllősre, majd a királynéhoz lehetett fellebbezni. ${ }^{144}$ Utóbbi rendelkezés, azaz a gonosztevők elfogása és elítélése gyakorlatilag pallosjogot jelentett. Bár, az sem kizárt, hogy az ekkoriban

\footnotetext{
${ }^{143}$ A tizedmentességükkel kapcsolatosan van egy nem sokkal későbbi adatunk: az öt város polgárai 1518-ban - nyilván a kiváltságlevélre alapozva - a Dolhai Péter aulicus erdeiben makkoló és legelő állataik után megtagadták a tizedfizetést. Nyilvánvalóan amiatt, hogy a tizedmentességük csak a saját birtokaikra vonatkozott, a király felszólította őket ennek teljesítésére. DL 86752.

${ }^{144}$ DL 22477: „,venientes nostre maiestatis in presentiam fideles nostri circumspecti Thomas Emerici iudex oppidi in Huszt, necnon Laurentius Szász iudex oppidi in Szigeth in suis, omniumque iudicum et iuratorum civium communitatumque quinque oppidorum nostrorum Maromorosiensium nominibus, exposuerunt nobis, quod licet ab antiquis temporibus certis libertatibus prerogativis et privilegiis" élveztek, így: „sylvas nostras reginales Nigras apellatas et campos adiacentes agere pascique, sed et aquis nostris et aquarum fluviis uti, fenetumque exinde capere potuissent, nec ab huiusmodi eorum pecoribus propterea decimas quispiam officialis noster exigendi habuissent libertatem, similiter etiam res et bona eorum ad partes exteriores, extra scilicet terram Maramarusiensem ducere, et dum comes huiusmodi res et bona victualia scilicet eorum pro se emere voluerit, liberam vendendi eadem cuicumque voluerint habuissent facultatem, nullo comite vel officiali nostro ipsos impediente. Preterea et inter cetera sua privilegia hoc unum habuisse, quod omnes causas que non directe ad cameram nostram vel comitem nostrum cameralem pertinerent, inter se subortas similiter et malefactores capitali crimine reos ipsi in singulis oppidis iudicare et iustitiam administrare absque ullo comitum nostrorum impedimento potuissent, cui vero parti iudicium huiusmodi ipsorum non placeret, illi ad conspectum viginti quatuor iuratorum a quibus ad locum interrogatorium Szölös quorum de hinc sententiam non contenti causam eandem coram nobis in curiam nostram provocare" legyen lehetőségük. Szövegét közli Wenzel 1857. 73-75. és Petrovay 1909. 513-515. Anna királynő végül a polgárság kéréseit szóról szóra teljesítette, egyúttal azt is kimondva, hogy a főbenjáró ügyekben vétkes nyilvános gonosztevőket is megbüntethetik, s azokat a bíró akarata ellenére szabadon engedni senkinek nem szabad: „tandem adiecto, quod neminem huiusmodi malefactores sine consensu iudicis... libertati restituere possint et valeant."
} 
elterjedt országos jog helyi érvényesítése lehetett, mely szerint a közbüntetteseket jobbágyi közösségek is fogságba ejthették és elítélhették. ${ }^{145}$ Mindenesetre a máramarosiak az újkorban is éltek a pallosjoggal. ${ }^{146}$

Szintén nagyon fontos - és új - információ, hogy az oklevélben a királynéhoz való fellebbezés előtt a hospesek Szőllőst említették meg mint felsőbb fórumot, s logikusnak tünik, hogy ha ez az 1329. évi oklevélben nem is szerepel, már minden bizonnyal 1504 előtt is megjelent az a gyakorlat a máramarosi mezővárosokban, hogy ha nem tudtak dönteni egy ügyben, akkor ezután a nekik a privilégiumokat adó Szőllős magisztrátusához fordulhattak vele. Ez a megoldás megfelelt az országban máshol is elterjedt joggyakorlatnak, amely szerint a városjogot kölcsönző város tanácsa fellebbezési fórumként múködött. ${ }^{147}$

Ez utóbbi azonban valószínűleg a kora újkorban lassan elhalhatott, mert a 18. században egy vizsgálat során kiderült, hogy szinte már senki sem emlékezett arra, hogy Szőllős valaha fellebbezési fórumként szolgált. Érdekes módon a 16-17. század fordulóján viszont a koronavárosok tanácsai működtek fellebbviteli fórumként az uradalom falvai számára. ${ }^{148}$

A máramarosi mezővárosok alapvető privilégiumaik mellett több kisebb kiváltságot is megszereztek, illetve a királyi hatalom többször kelt kiváltságaik védelmére. Ezek között van néhány kereskedelmi jellegű rendelkezés is. 1436-ban Zsigmond király küldött felszólítást Kusalyi Jakcs Mihály székely ispánnak, Perényi János ispánnak, Kusalyi Jakcs fiainak, a losonci és meggyesaljai nemeseknek és más birtokosoknak, hogy az élelmük megszerzése érdekében Erdélyben közlekedő máramarosi polgárokat ebben ne akadályozzák, valamint ne állítsák őket saját bíróságaik elé és ne is börtönözzék be őket. ${ }^{199} 1443$-ban I. Ulászló tiltja meg mindenkinek, hogy a kereskedő husztiakat feltartóztassák és zaklassák, vagy javaikat el-

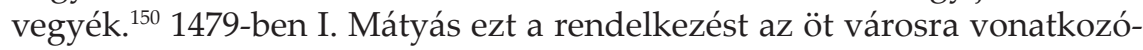

\footnotetext{
${ }^{145}$ A Hármaskönyv III. 20. pontja szerint a városok „publicos malefactores, iuxta eorum demerita, servatis de iure in hac parte servandis, castigare punireque possunt." Emellett a Tripartitum III. 32. cikkelyének rendelkezése: „Homicidas tamen et incendiarios, ac in adulterio violenti deprehensos, in loco delicti, sive facie vel territorio illius oppidi aut possessionis, ubi facinus huiusmodi patratum fuerit, captos et detentos, etiam oppida et villae ac nobiles, privilegia non habentes, observato iuris ordine, iuxta eorum demerita, feriendi atque puniendi habent authoritatem." Tripartitum 506-507. és 532-533.

${ }^{146}$ Glück 2013. 78.

${ }^{147}$ Ilyen fellebbezési joggal rendelkezett például a mezővárosok közül Modor, amely az 1361. évi kiváltságlevele szerint adóssági, illetve az úgynevezett „kisebb” ügyekben Nagyszombathoz, birtokügyekben pedig Pozsonyhoz fellebezhetett. Mályusz 1953. 145. További példákat hoz még Bácskai 1965. 89. (2. jegyzet).

${ }^{148}$ Glück 2013. 78, 80.

${ }^{149}$ DL 44122.

${ }^{150}$ DF 247893.
} 
an ismétli meg, s egyúttal azt is megtiltja, hogy a máramarosiaktól vámot szedjenek. ${ }^{151}$ II. Ulászló 1504-ben szintén a vámmentességüket védte. ${ }^{152}$

A máramarosi polgárok Aranyosmeggyes környéki kereskedelmére nézve 1449-ből rendelkezünk adattal. Demeter meggyesi provisor és Meggyes város tanácsa közösen kibocsátott oklevelében ugyanis vállalta, hogy ha Máramaros megye városainak és szabad falvainak nemes és nemtelen lakói igazságukért hozzájuk fordulnak, akkor ügyeikben, így például lefoglalt javaik vagy a különféle adósságok ügyében intézkedni fognak majd. ${ }^{153}$

A máramarosiak egyébként abban az esetben, ha a királyhoz látogattak, mindenféle vám fizetése nélkül megtehették, azonban a vámszedők ezt nem mindig tartották tiszteletben. Panaszaikra ezért V. László 1453ban megparancsolta, hogy őket ilyen esetben ne zaklassák, és semmilyen formában ne kényszerítsék fizetésre. ${ }^{154}$

Elmondható (és erre példákat is fogunk majd látni), hogy a helyben lévő sókamara bevétele mindig kéznél volt, amikor a király vagy a királynő kegyet akart gyakorolni. Ezt a sójáradékot az uralkodó olykor a máramarosi koronavárosok sérelmeinek orvoslására fordította. Legtanulságosabb ilyen esetünk 1498-ban történt. Az öt koronavárosnak a középkor végén az egyik legnagyobb sérelme az volt, hogy Perényi Gábor és István az ugocsai Tekeházán lévő vámhelyükön személyüket, lovaikat és szekereiket, valamint árujukat rendszeresen megvámolta. Ezért követeket küldtek a királyhoz, és kérték, hogy mentesítse őket a vámok, valamint az ezzel járó zaklatások alól.

A király 1498. december 3-i oklevele alapján személyesen hívta a színe elé Perényi Gábort, és végül sikerült megállapodnia vele. Az egyezség értelmében a polgárok mentesültek a vám fizetése alól, kivéve, ha a Tekeházán lévő réven kívánnak átkelni, ott ugyanis továbbra is meg kellett fizetniük, ami járt. A király cserében elrendelte, hogy évente 2000 sót utaljanak ki a Perényieknek, s egyúttal azt a feltételt is vállalta, hogy ha a sókiutalás megszünne a jövőben, akkor a vámmentesség is érvényét veszíti majd. ${ }^{155}$

A fentieken kívül további változatos ügyekben intézkedett még a királyi és királynéi hatalom máramarosi mezővárosai érdekében. Az egyik ilyen a településekre beköltöző jobbágyság szabad menetelének kérdése volt. A mezővárosokba való beköltözés joga, mint azt láthattuk, már az Anjou-kori kiváltságlevélben szerepelt. Elképzelhető azonban, hogy ezt a környék földesurai nem minden esetben tartották tiszteletben, ugyanis

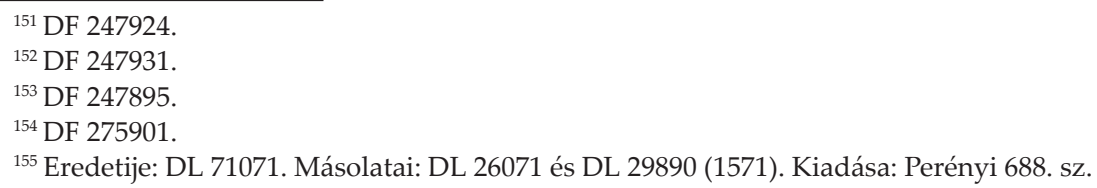


Mátyás 1482-ben elrendelte, hogy az ország régi szokásjogának megfelelően, amennyiben a költözés feltételeit a jobbágy teljesíti, szabadon Husztra költözhessen, és ebben őt senki ne akadályozza. ${ }^{156}$

1495-ben Beatrix királyné oklevelével a máramarosi polgárság és a kamara közötti viszályban próbál rendet tenni. Kiderült, hogy a polgárság javait a kamara tisztviselői az intézmény szükségleteire rendszeresen lefoglalták, anélkül, hogy ezért fizettek volna. A királyné ezért úgy határozott, hogy az érintett javakat, így például a sót adják vissza az érintetteknek. ${ }^{157}$

1506-ban II. Ulászló királytól az öt mezőváros sószállító szekeresei (curriferri dictorum oppidorum nostrorum) kaptak kiváltságlevelet. Eddigi szolgálataik jutalmául felmentést kaptak a rendes és rendkívüli adók alól, azzal a feltétellel, hogy a továbbiakban is a királynak kötelesek szolgálni. ${ }^{158}$

1514. április 9-én II. Ulászló megtiltotta, hogy az öt város lakói felett bárki is bíráskodjék, őket elfogja vagy javaikat lefoglalja, ehelyett mindenki forduljon a városok tanácsához, illetve, mivel a máramarosi polgárok mindenféle vám alól mentesek, senki se szedjen tőlük ilyet. A kiváltságot fia, II. Lajos két évvel később, 1516-ban szó szerint megismételte, mely 1652. évi megerősító átiratban maradt fenn. ${ }^{159}$

Nagyon érdekes megjegyzéseket tartalmaz az a következő évi (1517. július 13.) királyi oklevél, amelyből a lakosság további privilégiumai rajzolódnak ki. Ekkor II. Lajos parancsot adott Perényi Gábor és Pogány Zsigmond kamaraispánoknak és embereiknek, hogy az öt városban lakó nemeseket, akik a korábbi királyi kiváltságoknak köszönhetően mentesek mindenféle teher - így rendes és rendkívüli adók és egyéb szolgáltatások - alól, illetve arra is jogot élveztek, hogy a kamarából sót adhatnak el, joga-

\footnotetext{
${ }^{156}$ DF 247918.

${ }^{157}$ DF 275910.

${ }^{158}$ DF274897.
}

${ }^{159}$ Petrovay 1909. 518-519. A király felszólít mindenkit, hogy „,fideles nostri circumspecti cives, populique et inhabitatores oppidorum Huzth, Visk, Thechew, Hozzwmezew et Zigeth, aut homines et familiares ipsorum... in personis iudicare vel vestro adstare iudicatui compellere, resque et quevis bona mercimonalia ipsorum civium arestare seu prohiberi facere nequaquam presummatis, nec sitis ausi modo aliquali." Ha pedig a polgárokkal bármilyen ügyük lenne, akkor „in presentiis iudicum et iuratorum civium prelibatorum oppidorum legitime prosequantur" stb. És mivel a nevezett városok vámmentességet élveznek, a király felszólít mindenkit, hogy „,a prefatis civibus hominibusque et familiaribus ipsorum, necnon rebus et bonis eorundem in locis dictorum tributorum, quam aliorum quorumcumque in eundo et redeundo atque passuando contra libertates eorum nullum tributum" szedjenek. Az oklevél eredetije: DF 274898; emellett egy 1769. évi másolatból ismert.Valószínúleg ugyanezt az oklevelet említi néhány sorban, szintén Simonchiczra hivatkozva Wenzel 1857. 75. 
ikban ne gátolják, de arra is figyeljenek, hogy ebből kifolyólag a kamarát se érje kár. ${ }^{160}$

\footnotetext{
160 "Expositum exstitit maiestati nostre in personis fidelium nostrorum nobilium, in ipsis quinque oppidids nostris commorantium, quod ipsi quamvis ex concessione et gratiosa provisione divorum regum Hungariae, predecessorum nostrorum felicis memoriae, ab omni solutione taxarum ordinarium et extraordinarium, necnon impensione servitiorum nobis, et in medium oppidanorum quomodocumque faciendis et prestandis, ab aliis etiam omnibus oneribus exempti in perpetuum sint, hac denique iidem specialis gratia prerogativa condonati habeantur, ut ipsi et quilibet eorum continuis semper temporibus in cameris nostris Maramorosiensibus sales levare et educere atque vendere possunt." A király megparancsolja tehát a kamarai tiszteknek és a városoknak, hogy ne akadályozzák ezen nemesek kiváltságait, stb. Petrovay 1909. 523-524. Eredetije szintén ismeretlen. Figyelemre méltó, és az oklevél hitelét növeli, hogy ugyanazon napon kelt, mint a király Barilovics Miklós számára kiadott, lentebb ismertetendő, kocsmáltatási jogot szabályozó oklevele. DL 84631.
} 



\section{MAGYAROK, NÉMETEK, ROMÁNOK ÉS RUTÉNOK}

Máramaros etnikai szempontból erősen kevert jellegű volt: a városokban kezdetben német és magyar, később, Visk kivételével, kizárólag magyar elemek találhatók, a románok és ruténok pedig vidéken, a falvakban laktak. ${ }^{161}$

A németek és a magyarok a városokban eleinte együtt éltek, amíg a szászok lassan el nem magyarosodtak, nagyjából a 15-16. század folyamán. A románokkal a városlakók kapcsolata a birtokoslétből adódott: a városok határai, és a városban élő lakosság magánbirtokai ugyanis sokszor vlah biroktömbökbe ékelődtek, ami főleg Hosszúmező, Sziget és Técső esetében konfliktusokat: pereket és hatalmaskodásokat eredményezett. A Máramarosban ekkor még forrásokban alig-alig kimutatható - amúgy az oklevelek alapján Erdélytôll a nyugati Felvidékig nagy számban megtalálható - szláv nyelvet beszélő ruténokkal a városlakóknak nem lehetett túl szoros a kapcsolatuk, legalábbis alig van adatunk arra nézve, hogy milyen lehetett a viszonyuk.

\section{A máramarosi német hospesek}

A terület kezdeti benépesedése és a városi fejlődés megindulása során az ország sok más peremterületéhez hasonlóan itt is kitüntetett szerepet játszottak a német hospesek. Betelepedésük Ugocsa felől történt, ahol már

\footnotetext{
${ }^{161}$ A városi lakosság magyar mivoltát vallja például Wenzel 1857. 80; Bélay 1943. 27; Glück 2013. 15. stb.
} 
Máramarost megelőzően megjelentek a szászok Szőllős, Ardó, Nagyszász és Felszász (Királyháza) településeken. ${ }^{162}$

A német betelepülők legfontosabb központja a környéken egyértelmúen Szőllős volt. A település 1262-ben kiváltságlevelet is szerzett, amit a térségben élő németek láthatóan egyfajta kiváltságolási mintának, viszonyítási alapnak tekinthettek, így később azt az ugocsai Királyháza, Ardó, Nagyszász és Veréce hospestelepesei is megkapták. Ez kimondta, hogy vitás esetekben a szőllősi bíróhoz és esküdtekhez fordulhatnak, ítéletüket pedig mind maguknak a hospeseknek, mind a nyalábi várnagynak el kell majd fogadniuk. ${ }^{163}$

A szőllősi kiváltságokat - pontosabban, azok egy jelentős részét - a későbbiekben máramarosi városaink is elnyerték. Habár ezt a kiváltságlevelük konkrétan nem említi, mint azt láthattuk, a szőllősi tanács a máramarosi hospesek számára szintén fellebbviteli fórum volt.

A hagyományos és téves felfogás szerint ez a német eredet a településnevekben is megörződött. Huszt neve ellenben minden bizonnyal magyar eredetű lehetett, legalábbis egyértelmüen onnan került át a későbbiekben a szlávba. ${ }^{164}$ Hosszúmező és Máramarossziget elnevezése szintén magyar, amely párhuzamos névadás során a románban is megjelent. ${ }^{165}$ Técsó és Visk helyneve egyaránt személynévi, mégpedig magyar személynévi eredettel bírt. ${ }^{166}$ Ezek alapján pedig az tűnik a leginkább valószínúnek, hogy városaink nem új német alapítások voltak, hanem a területre bevándorló hospesek már fennálló magyar településekre érkeztek és költöztek be. Nem fogadható el az a másik, németekkel kapcsolatos tévhit sem, miszerint a hospesek betelepítésében a Német Lovagrend játszotta volna főszerepet. ${ }^{167}$

\footnotetext{
${ }^{162}$ A magyarországi német betelepedésre, a hospes kifejezés értelmezésére lásd Fügedi 1979. 354-376. Az ugocsai német telepesekre lásd Szabó I. 1994. 20-25. Szintén Ugocsából származtatja őket Bélay 1943. 13.

${ }^{163}$ A privilégium kiadása: ÁÚO VIII. 31-32. Az említett hospestelepek 1355-ben nyerték el a kedvezményeket. Szabó I. 1994. 21. A másik ugocsai kiváltságlevelet, az 1271. évi felszászit már említettük. Lásd 49. jegyzet.

${ }^{164}$ Kiss 1988. I. 617. Az a magyarázat, miszerint Huszt város nevét a másik négy város nevének kezdőbetűiből hozták volna létre (!), a regényes toposz kategóriába sorolható. Szöllősy 1994. 26-27.

${ }^{165}$ Kiss 1988. I. 611. és II. 90.

${ }^{166}$ Kiss 1988. II. 627., Viskre lásd uo. II. 769. Egyébként Técső nevével kapcsolatban merült fel leginkább a német eredet lehetősége a régebbi helytörténeti- és szakirodalomban. Ezen vélemények kritikáját lásd Tóth 2008.

${ }^{167}$ A Lovagrend alapító tevékenységével kapcsolatos érvrendszert erélyesen és teljesen jogosan bírálja Pap 1909. 16-21. A feltételezés egyébként egy valószínűleg hamis, 1213. évi oklevélre épül. CDH X/3. 249. Elfogadja ugyanakkor a Lovagrend telepítő tevékenységét Mihályi János. Már. Dipl. 5
} 
A máramarosi, már talán ekkor részben német hospesekre vonatkozó első okleveles adatunk 1300-ból származik, amikor a Viskkel kapcsolatos birtokcsere során esik róluk említés, igaz, ekkor még az etnikum konkrét megnevezése nélkül. ${ }^{168} \mathrm{Az}$ 1329. évi kiváltságlevél azonban már ezt is pontosítja. ${ }^{169} \mathrm{~A}$ németség valószínűleg lassan asszimilálódott, ennek ellenére még a 15. század első felében is beszélnek a források a városokban élő szászokról. ${ }^{170} \mathrm{~A}$ lassú beolvadás ellenére a lakók személyneveikben elég sokáig őrizték német etnikai jellegüket.

Az 1610. és 1614. évi, említett összeírásokban vannak még német nevet viselő polgárok Huszton, Szigeten, Técsőn és Hosszúmezőn is, de csupán egy-két ilyen família mutatható ki településenként. Sokkal tartósabb lehetett a német etnikum jelenléte ugyanakkor Visken, ahol még 1673-ban is 4 német nevü személy szerepel a 12 tagú tanácsban. ${ }^{171} \mathrm{Az}$ újkorban is több említés esik a „viski szászokról”, amely kifejezés egyébként egészen a modern időkig az ottaniak gúnynevévé vált. ${ }^{172}$

\section{A vlahok beköltözése és birtokaik}

A németek mellett idegen népelemként a vlahok is megjelentek Máramarosban. A szászokkal ellentétben azonban ők itt nem városi népességet alkottak, hanem a környező területen falvakat hoztak létre és társadalmi, illetve topográfiai értelemben is érezhetően erőteljesen elhatárolódtak az öt királyi város lakosságától, akárcsak a szintén ekkoriban a térségbe érkező ruszinok.

Magyarországra telepedésük aránylag későn ment végbe. ${ }^{173} \mathrm{~A}$ balkáni hegyek felől lassan északkeleti irányba vándorló románság legkorábban valamikor a 12. század második felében érhette el Dél-Erdélyt. Irásos forrásaink - s ezáltal hiteles bizonyítékaink - azonban csak az 1210-es évektől

\footnotetext{
${ }^{168}$ Györffy IV. 24. A viski várra III. Andrásnak „in subsidium populorum seu hospitum nostrorum --- nostra Mammarus congregatorum" volt ugyanis szüksége. CDH VI/2. 254.

${ }^{169} \mathrm{CDH}$ VIII/3. 353.: "quod nos considerantes fidelitates hospitum nostrorum fidelium de Maramorusio, Saxonum et Hungarorum, videlicet in villis Visk, Huszth, Tecsö, et Hosszumezö".

${ }^{170}$ Az egyik legkésőbbi említés a szász telepesekről Zsigmond idejéből származik. Az 1329. évi kiváltságlevél késői, 1435. március 12-i királyi megerősítése az öt város szász és magyar királyi jobbágyainak és népeinek kérésére történik: „fideles nostri Joannes dictus Kethel de Visk et Benedictus magnus de Hust villici, in eorum ac universorum hospitum seu iobagionum populorum Saxonum et Hungarorum". DL 2539. Persze az sem kizárt, hogy az oklevél átírója csak a korábbi szöveg frázisait ismételte meg automatikusan.

${ }^{171}$ B. Gábor 1975. 8; Bélay 1943. 28-29.

${ }^{172}$ Bélay 1943. 28; Igyártó 2005. 42.

${ }^{173}$ Etnogenezisükre és vándorlásukra lásd összefoglaló jelleggel Menasági 1994; Vékony 1996; Kristó 2002. 190-192; Frivaldszky 2005. 449-451.
} 
vannak a jelenlétükre. Minden bizonnyal az Olt folyó völgyében észak felé húzódva érhették el Fogaras vidékét. ${ }^{174}$

A 14. században feltűnő máramarosi románság sajátos volt abban az értelemben, hogy etnikai és nyelvi szempontból a ruszinokkal keveredve élt, s ez nem csak Máramarosban figyelhető meg, hanem a mai Szlovákia területén nyugati irányban egészen a Kis-Fátráig így történhetett, amely a vlahok nyugati településterületének határa is volt egyúttal. Újabban az is felmerült, hogy a máramarosi románok a románság egy sajátos csoportját alkották, és az aromán dialektust beszélték. ${ }^{175}$

A románok Máramarosban az 1320-as évektől tűnnek föl először oklevélben, mégpedig Borzán (Barcán) irányításával Barcánfalván, illetve Bedő fiai Drag és Dragos vezetésével a Técső melletti Bedőházán. Olyan vélemény is ismert a régebbi szakirodalomban, miszerint ez a betelepedés jóval korábbi lett volna, és a románok már 1285-ben megtelepedtek királyi szándékból Máramarosban. Ezt azonban a rendelkezésre álló források egyáltalán nem támasztják alá. ${ }^{176}$

Az 1330-as évek közepén Mykola fia Bogdán vajdával - aki központját az Iza melletti Konyha faluban rendezte be - már egy sokkal komolyabb létszámú vlah csoport érkezhetett Szerbia irányából. ${ }^{177} \mathrm{Az}$ új beköltözők érkezése nem volt problémamentes, az 1330-as és 1340-es években több összetüzésről van adatunk részint távolabb, a Maros mentén, részint Szatmárban, sőt, népe a korábban megtelepült Dragost és vlahjait is menekülésre késztette, akik végül a Kárpátok túlsó oldalán, Moldvában találtak új otthonra. A beköltözés első hulláma valószínűleg 1339-re zárulhatott le. ${ }^{178}$

A 14. század derekára már több, románok lakta település ismert a megye területén. Lássunk ezek közül néhány példát. Szarvaszót 1345-ben Aprusa és Marus bírta. Konyha birtok - miután Bogdán valószínűleg 1349 körül Moldvába szökött - 1365-ben Szász vajda Moldvából Máramarosba menekült fiai, Balk vajda, Drag, Dragomér és István kezébe került. Felső-

${ }^{174}$ Kristó 2002. 192-193.

${ }^{175}$ Frivaldszky 2005. 455-457.

${ }^{176}$ A korai román betelepedést vallja például Wenzel 1857. 13; Petrovay 1911. 612-613. Máramarosba telepedésükre összefoglalóan lásd Bélay 1943. 14-17. Ô egyébként a „várispánsági szervezet" létrehozásához köti beköltözésüket, tévesen. Barcánfalvára és Bedőházára: Györffy IV. 122. és 128. Bedő határait 1336-ban járták meg és határolták el Técsőtől. Már. Dipl. 13-17. Szurdok 1326. évi vlah betelepedésére lásd Már. Dipl. 6-8. Az oklevél 1346. évi megerősítése: Már. Dipl. 21-22.

${ }^{177}$ Mykola fia Bogdán népének nem sokkal korábbi Máramarosba vonulásáról 1335 októberében számol be egy forrásunk. Már. Dipl. 11-13. Vö. Györffy IV. 118-119.

${ }^{178}$ A románság (de főként Bogdán és rokonsága) beköltözésével kapcsolatos eseménymenetről részletesen megemlékezik Bélay 1943. 14-17.; Györffy IV. 114-120. és Petrovay 1911. 614-618. A máramarosi románság moldvai kitelepedésére lásd összefoglalóan Wenzel 1857. 23-31. 
rónát Péter fia Sztán 1360-ban már nem is keneziátusként, hanem a hazai birtokosokhoz hasonlóan nemesi jogon szerezte. 1363-ban Fejéregyházat Balk, Drag és János kapták meg, Gyulafalvát pedig Dragos fia Gyula 1349 előtt már bizonyosan bírta. ${ }^{179}$

Szintén Nagy Lajos korában kerülhetett Felső-, Közép- és Alsóapsa egy része is a román betelepülők kezére, legalábbis Zsigmond 1407. évi oklevele ezt állítja. ${ }^{180}$ A letelepedést szervező, adófizető és katonáskodó kenézeik és - a korai időszakban - a máramarosi oláh vajda irányítása alatt álló románság a későbbiekben is főleg a városok szomszédságában fekvő falvakban élt, saját vallását gyakorolta és rendszeresen szerepelt a különféle, környékbeli ügyekben. A románság Máramarosban - az országos nemesség szintjének eléréséig - egyébként a huszti várnak tartozott munkaszolgálattal és különféle járadékokkal. ${ }^{181}$

A máramarosi kenézségek és a vajdaság intézménye a beköltözés után viszonylag gyorsan megszilárdult. Mutatja ezt, hogy 1364-ben, amikor Erzsébet királyné engedélyezte a beregi románoknak, hogy vajdát válasszanak, azt már olyan módon tehették meg, ahogyan ez a jog Máramarosban és az ország más részein is köztudottan megillette a vlahokat, azaz a máramarosi helyzet a beregiek számára már egyfajta példaértékkel bírt. ${ }^{182}$

A kenézi cím családon belül apáról-fiúra öröklődött. A kenézek a királytól vagy világi földesúrtól kapott területen népeket telepíthettek le, akik felett joghatóságot gyakorolhattak, a juhötvened fele őket illette, cserében pedig a huszti (Beregben a munkácsi) várnak volt köteles katonai szolgálatot teljesíteni, külháborúban is, a vajdáik irányítása alatt. A beregi kenézek főbb kiváltságai nagyban hasonlíthattak a máramarosiakéhoz. A Munkács melletti krajnai vlah falvak kenézei a 15. század közepén bíráskodhattak a település lakói felett, de csak a kisebb ügyekben, officiális viszont nem intézkedhetett ilyen esetekben; népeik cenzusa évi egy arany-

${ }^{179}$ Már. Dipl. 20, 56; Györffy IV. 122-123., 128. A Moldvába költözést Györffynél korábbra, 1343-ra teszi Petrovay 1911. 619. Már. Dipl. 42. Gyulafalva és Nyíres román birtokosai: Már. Dipl. 28. és 35. Szásznak volt egy ötödik fia is, Oláh János is, aki 1373-ban jelenik meg Máramarosban. C. Tóth 2012. 136. A Drág-fiak több birtokot szereztek és rendszeresen töltöttek be különféle tisztségeket a környéken: Balk több ispáni címet is viselt (máramarosi, szatmári, ugocsai és székely ispánság) testvéreivel együtt. Oláh János királyi lovászmester címet szerzett. Máramarosban 1402-ben töltik be utoljára az ispánságot. Uo. 136-144.

${ }^{180}$ Már. Dipl. 81. 143. Lásd még uo. 147. és 150.

${ }^{181}$ Beatrix királyné 1485. évi okleveléből tudjuk azt, hogy Lőrinc máramarosi oláh pap a huszti várnak szolgált. DL 71005, DL 71006. Kiadása Perényi 607., 608. sz.

182 "de communi voluntate eis preficere admitteremus, secundum quod etiam alii wolacy in Maramorosyo et aliis partibus regni nostri residentes Hungarie potirentur libertate". Már. Dipl. 28. 55. A beregi románok felett a polgárok és hospesek nem, csakis saját uraik bíráskodhattak. Már. Dipl. 59. (1366). Kiadta még Lehoczky 1890. 164. Vö. Pach 2001. 793-794. 
forintot tett ki, akik emellett természetbeni járadékokkal (juh, marha, sajt) is tartoztak nekik. ${ }^{183}$

A vlahok önálló és szabad hitélettel rendelkeztek a térségben, amit a magyar királyok nem akadályoztak. ${ }^{184}$ Ennek az önálló vallásosságnak a legjobb jele, hogy Hosszúmezővel szemközt, a Duna túlpartján, Körtvélyesen volt egy bazilita monostoruk, amely 1442-től - éppen a helyi románság kérésének megfelelően - kapta meg Körtvélyest adományként. ${ }^{185}$ Igaz, van egy adatunk, amely szerint gyakorlatilag ez már korábban is így volt. Már 1438-ban is a körtvélyesi Szent Mihály-kalugerek birtokának említette a falut egy határjárást elrendelő nádori parancslevél. ${ }^{186} \mathrm{Az}$ alapítása Balk és Drág nevéhez köthető, és valamikor 1385 és 1391 között történt a már említett Szent Mihály tiszteletére. ${ }^{187}$

Az alapítók a románság erős helyi támaszának szánták az intézményt. Nem véletlen, hogy a Szent Mihály kalugereket 1391-ben Balk és Drág Konstantinápolyban Antonius patriarcha oltalma alá helyezte, aminek eredményeképpen az apát megkapta az engedélyt arra is, hogy a Szilágyságban, Ugocsában, Meggyesalján, illetve Közép-Szolnokban templomokat szenteljen fel. Apátját a hívekkel együtt Balk és Drág választhatta meg. ${ }^{188}$

Kiváltságaikat több királyunk is gyarapította. I. Mátyás 1479-ben felmentette a máramarosi keleti vallású papokat a rendes és rendkívüli adók fizetése alól. ${ }^{189} 1494$-ben II. Ulászló megerősítette az Antonius-féle oklevelet, egyúttal kijelentve, hogy apátja, Hilarius a munkácsi püspök felé tisztelettel tartozik. ${ }^{190} \mathrm{Az}$ apát befolyása a középkor végére megnőtt. Az apátság vezetőjét 1491-ben a ruténok püspökének, az újkorban pedig „oláh püspöknek" nevezték. Igaz, hívei ekkoriban már főleg ruténok lehettek. ${ }^{191}$

\footnotetext{
${ }^{183}$ A román vajdaság és kenézség intézményéhez és történetéhez lásd alapvetően Lehoczky 1890. (aki több kenézlevelet is közölt a Munkács környéki, krajnai kenézekkel kapcsolatosan) és Petrovay 1911. 621-626.

${ }^{184}$ Ismerjük saját papjaikat a környéken többek között Gyulafalváról, Középapsáról és Visóról is. Mihályi 1889. 65.

${ }^{185}$ DL 13687, DL 13688.

${ }^{186}$ Már. Dipl. 178., 306.

${ }^{187}$ F. Romhányi 2000. 39. Wenzel szerint az alapítás egy korábban ott állt katolikus kolostor helyén történhetett, amely szerinte a máramarosi konventtel azonos intézmény volt. Wenzel 1857. 14-15. A helység neve szerinte Máramaros volt. Ez az az általa feltételezett település, ahonnan V. István 1272-ben oklevelet datált. CDH V/1. 210-211. Petrov Elek felveti, hogy a monostort nem Balk és Drág alapította, hanem ők csak egy új templomot építettek a már meglévő egyház számára. Petrov 1925.

${ }^{188}$ Antonius oklevelét kiadta Mihályi János. Már. Dipl. 109-111.

${ }^{189}$ Már. Dipl. 536.

${ }^{190}$ Már. Dipl. 606.

191 "fidelis noster reverendus Ioannes episcopus Ruthenorum in claustro Beati Michaelis archangeli in Maromarus situ Graecorum fundato commorans" - Már. Dipl. 600; Bélay 1943. 44.
} 


\section{A városok és a románság}

A városok és a környékükre beköltöző románság viszonya a források alapján nem volt éppen problémamentes. Ezt már a kiváltságlevél egyértelműen vlahokra utaló megjegyzése is sejteti. Az újonnan beköltözőket a nem sokkal előttük érkező helyi magyar és német telepesek nem láthatták szívesen, amiben az eltérő életmódjuk is szerepet játszhatott, így a konfliktus minden bizonnyal főleg birtokjogi jellegü volt. Ez alól pedig az országos nemességbe lassan integrálódó román vezetőréteg sem képezett kivételt.

A régóta feszülő ellentétnek lehetett az eredménye, hogy 1424-ben, amikor az úrmezeiek részére határjárást tartottak, s már maga a beiktatás is megtörtént, mégpedig ellentmondás nélkül, a técsői polgárok egyszerüen meggyilkolták a régi „ellenlábas” családhoz tartozó Bedői István királyi embert. ${ }^{192}$ 1435-ben Bedőházi Sztankó panasza alapján ugyanők elfoglalták bedőházi birtokuk felét a Szent Miklós-templommal együtt, jobbágyaik nyájait elhajtották, egy tehenet, egy ökröt és öt sertést pedig levágtak. ${ }^{193}$ 1436-ban pedig, amikor Zsigmond parancsára a leleszi konvent Bedőháza határait akarta megállapítani, a técsőiek összefogtak a szintén a környéken birtokos Irholci Thatullal, és fegyveresen akadályozták meg a határjárást, sőt, megrohanták Bedőházi Sztankó kúriáját, akire az udvarházat rágyújtották, más épületeit is felégették, felesége ruhájának ezüstgombjait leszaggatták, és Dancs királyi embert félholtra verték. A polgárokat tetteikért a király elé idézték. ${ }^{194}$

A hosszúmezeieknek szintén nem volt valami rózsás a viszonyuk a szomszédaikkal. Már 1373-ban határigazítást kértek a szaploncai nemesek és a település határának vonatkozásában. ${ }^{195} 1456$ áprilisában a királytól a település határainak bejárását kérték, ám a szomszédos Szarvaszói Gerhes Péter, Szaploncai Lukács és a Szent Mihály-monostor kalugerei az újonnan állított határjelek miatt ellentmondással éltek. ${ }^{196}$ Ezzel nyilvánvalóan összefüggésben a polgárok számos hatalmaskodást követtek el szomszédaikon az elkövetkező években: az ellenfelek szántóit, rétjeit és erdőit elfoglalták, a Szent Mihály-monostort pedig huszonnégy marhájától szabadították meg sikeresen. Apsa határában két szénásszekeret raboltak el, összesen négy

\footnotetext{
${ }^{192}$ Már. Dipl. 264.: „prefatus homo regius in suis factis et negotiis expediendis coram eo, scilicet nostro testimonio per cives et hospites regales de Theucheu omni sua sine culpa nece miserabili interemptas extitisset."

${ }^{193}$ Már. Dipl. 300. A bűntett elkövetői: „iudex et iurati necnon ceteri cives oppidi nostri Thechew vocati".

${ }^{194}$ Már. Dipl. 302.

${ }^{195}$ Már. Dipl. 69.

${ }^{196}$ Már. Dipl. 376.
} 
ökörrel. Deák Miklós hosszúmezei bíró ráadásul egy szarvaszói jobbágyot is meggyilkolt. Végül 1457. november 9-én a máramarosi ispán fegyveres támadásaikért és az elrabolt javakért a települést 100 budai márka bírságra, a bírót pedig 25 forint vérdíj megfizetésére ítélte. A per azonban még a következő évben is folyt az ügyben, ezért 1458. február 28-i oklevelében Upor László máramarosi ispán a kérdéses birtokokban időlegesen megerősítette a sértetteket, a végső döntés megszületéséig. ${ }^{197}$

Az 1460-as években Stibor Mihály szigeti lakos és társai hatalmaskodásai borzolták leginkább a kedélyeket a térségben. 1461. február 5-én Mátyás király értesítette Sziget városát, hogy a polgártársuk által Szarvaszói Gerhes Péter birtokán elkövetett hatalmaskodások ügyében Szapolyai Imre kincstartót bízta meg az ügy kivizsgálásával, tehát vessék alá magukat a kincstartó ítéletének. Ugyanaznapi keltezéssel fennmaradt a Szapolyainak írt parancslevele is, melyben az ügy kivizsgálására és a döntésre ad utasítást.

Ebből megtudjuk, hogy Stibor Mihály egy bizonyos Rosa Györggyel együtt István szigeti bíró ösztönzésére hatalmaskodott, másrészt pedig azt is, hogy a korábban is igen aktív hosszúmezei lakosok ezúttal a közelben lévő Szent Mihály-kalugerekkel fogtak össze s közösen elfoglalták Gerhes Péter szarvaszói részbirtokát. Az év végén a király felszólította a vármegyét is az ügy rendezésére, de láthatólag mégsem sikerült ítéletet hozni, hiszen még 1462 augusztusában sem született döntés. ${ }^{198}$

Az eset nem illeszthetô egyértelmüen a fenti román birtokosokkal szembeni konfliktusok sorába. Mátyás király 1462-es és 1464-es okleveleiből ugyanis kiderül, hogy ez a bizonyos Stibor nem egyszerü hospes lehetett, hanem minden bizonnyal a Gyulafalvi-rokonságba tartozott, ez esetben pedig talán valamilyen régi családi sérelem vagy birtokviszály állhat a háttérben. ${ }^{199}$

\section{A ruténok}

Úgy tünik, a ruténok a szomszédos Ugocsában és Beregben jóval nagyobb társadalmi súllyal bírhattak, mint Máramarosban. Berendezkedésük hasonlított a románokéhoz, abban az értelemben, hogy a ruténok sok esetben kenézségeket alkottak. Ez nem véletlen, hiszen több adatunk is van arra nézve, hogy a ruténok a románokkal keveredve telepedtek meg,

\footnotetext{
${ }^{197}$ Már. Dipl. 395., 402., 406.

${ }^{198}$ Már. Dipl. 435., 437., 438., 442., 444.

${ }^{199}$ Mátyás 1462. október 6-i oklevelében a következőképpen szerepel az illető: „Michaele Sthybor, alio nomine similiter Gyula dicto de dicta Gyulafalva, nunc in oppido nostro Ziget vocato commorante". Már. Dipl. 445. Az 1464. évi említés: Már. Dipl. 460.
} 
s gyakran román földesuraik voltak. Ilyen esetben megkülönböztetni sem könnyű őket egymástól.

Olykor, ha az oklevelek precízen fogalmaznak ebben a kérdésben, két fajta meghatározás-típus szerepel az itt élő népekkel kapcsolatosan. Etnikai értelemben beszélhetnek magyar (Hungaricales), román (Valachicales) és rutén (Ruthenicales) népességről, de egyházi szempontból csak keresztény és rutén egyházakról szólnak a dokumentumok. Utóbbi mögött - amely a görögkeleti hitet takarja - pedig a román és rutén hívek is megbújhatnak, míg az előbbi egyértelműen a magyarok és németek jelenlétét mutatja.

Ha viszont nem a fenti megközelítésmóddal, azaz nem egy másikkal párhuzamba állítva alkalmazzák a vlah (valachalis - valachicalis) kifejezést, sokszor gyakorlatilag egyáltalán nem lehet eldönteni, hogy vajon ruténokról vagy románokról lehet-e beszélni, mivel a szó gyűjtőfogalom is volt egyben, amelyet általában a hegyi pásztornépekre alkalmaztak, etnikumtól teljesen függetlenül. ${ }^{200} \mathrm{~A}$ térségben a források szerint legnagyobb számban Máramaros, Ugocsa és Bereg megyék határainak találkozásánál, a Tisza nyalábi kanyarulatától északra élhettek. Lássunk erre néhány példát. Az ettől a területtől távolabb élő ruténokkal ezúttal nem kívánok foglalkozni. ${ }^{201}$

Bereg megyében, annak keleti, máramarosi határvidéke közelében jól dokumentálható a ruténok jelenléte. 1393-ban például Almáson beszélnek oláh és rutén jobbágyokról. ${ }^{202}$ Beregben voltak egyébként olyan települések is, amelyekben a ruténok és magyarok keverten éltek. Ilyen esetekben mind a két felekezetnek saját temploma és saját temetője is volt, mint például a Munkács mellett fekvő Sarkadon és Makarián 1418-ban ez megfigyelhetö. ${ }^{203}$

\footnotetext{
${ }^{200}$ Szabó I. 1994. 51.

${ }^{201}$ Persze erre is bőven lehetne még példákat sorolni: feltűnnek Zemplén megyében (CDH IV/2. 226.), Túrócban (HO VII 83.), a Szepességben (ZSO II. 1473. sz.) Kurima mezőváros és Makovica vára környékén (DL 24482, DL 5625), Torda környékén (DL 26816) stb.

${ }^{202}$ DL7858: „cum iobagionibus, Olachis scilicet et Rutenis, ad dictam villam Almas spectantibus".

${ }^{203}$ Már. Dipl. 223.: „Item in possessione Sarkad... duas capellas ligneas, unam videlicet christianorum cum turri lignea, et aliam ruthenorum, ambas cum cimiterio et sepultura" stb; „in possessione Makaria... duas capellas ligneas, unam videlicet christianorum et aliam ruthenorum, ambas cum cimiterio, dictam capellam ruthenorum cum sepultura". Már. Dipl. 223. Problémát okoz, hogy a „rutén” hit nem etnikai jellegü kifejezés volt, hanem a keleti kereszténységre utal. Mégis, mivel ezen a területen aránylag sok említés esik - etnikai értelemben! - erről a népcsoportról, feltételezhetően itt tényleg szlávokról van szó.
} 
Ugocsában a témánk szempontjából fontos rutén telepek nagyrészt a nyalábi váruradalom birtokain találhatók. 1471-ben az erődítmény tartozékaiként esik szó ugocsai magyar, vlah és rutén falvakról. ${ }^{204} \mathrm{~A}$ nyalábi uradalom itt felsorolt falvai közül az oláh és magyar falvak a Tisza bal partján találhatók, míg a ruténok a folyótól északra telepedtek meg, egészen Rákóc, Misztice és Lukova térségéig, azaz a települési területük Bereg megyébe is átnyúlik.

Az itt jelen lévő rutén elemet bizonyítja még egy 15. század végi oklevél is. 1483-ban Máramaros megye közvetlen határában lévő falvak hatalmaskodásban részt vett jobbágyait sorolják fel, akik nagyobb részt szláv, kisebb részt magyar nevet viselnek. ${ }^{205} \mathrm{~A}$ Nagyszőllősi-hegység rutén települései egyébként már 1351-től adatolhatók. ${ }^{206}$ Érdekes és jól jellemzi a térség bonyolult etnikai viszonyait, hogy a nyalábi uradalomban egy kifejezetten kicsi, 10-15 kilométeres sugarú körrel körberajzolható területen három etnikum is aránylag sok települést hozott létre.

Ungban a Császlóciak 1393. évi osztályánál szintén hallunk ruténokról, akik Ungvár és Munkács között, a Szerednye mezőváros melletti Csertész és Zavada falvakban élnek, magyarokkal vegyesen ${ }^{207}$ Ungvártól északra, Szobránc környékén Koromlyán 1437-ben és 1454-ben pedig a ruténok papját említik, azaz hitközséggel is rendelkeztek, ami azt mutatja, hogy nem lehettek kevesen. ${ }^{208}$

A fentebb vázlatosan felsorakoztatott adatokból kitünik, hogy Máramaros megye nyugati határvidékén, a szomszédos Ungban, Beregben, de főleg Ugocsában mindenhol megjelentek a rutén telepesek. Ezek alapján pedig a mezővárosok környékén is bizonyosan jelentős számban telepedhettek meg, hiszen ez a terület még alacsonyabb népsürüségű volt, ami már jó ideje betelepítésre várt. Ehhez képest viszont elég kevés forrás számol be a rutén jelenlétről a megyéből.

\footnotetext{
${ }^{204}$ A birtokrészt Perényi Miklós zálogosítja el 32000 forintért Bátori Miklós szerémi püspöknek 1471 februárjában. Márciusban azonban Perényi János fiai tiltakoztak a zálogosítás ellen. Perényi 539. sz., DL 70952 és Perényi 543. sz., DL 70956. Magyar (Hungaricales): Királyháza, Verőce, Veresmart, Tekeháza, Szászfalu, Feketeardó, Gyula, Tőketerebes, Szőllős; Oláh (Volachicales): Kirva, Csarnatő, Széphegy, Szárazpatak, Komlós, Batarcs, Alsógerce, Felsőgerce; Rutén (Prutenicales): Alsósárad, Felsősárad, Alsócsongova, Felsőcsongova. Vö. Wenzel 1857. 81-82.

${ }^{205}$ Csak a ruténokat sorolom fel. Ilosváról: Simon Kosorka, Michael Selpak, Mathias et Georgius Berendez, Lucas Warsycz; Kisfaludról: Ivan Thalchenycz; Iloncáról: Michael Kozthyn; Bilkéről: Iohannes Pyriska, Mathe filius Brod, Clemens filius Mathei Mykocha, Lucas Zamoyla, Hamylko, Demko, Iohannes Kosolya, Kostha faber, Andreas Herepthysthe, Ivan Zamoyla, Lucas Spacha. DL 105783.

${ }^{206}$ Az ugocsai szláv telepekre összefoglalóan lásd: Szabó I. 1994. 45-56.

${ }^{207}$ Perényi 168. sz. 105-106. Vö. Engel 1985. 949-950.

${ }^{208}$ Sztáray II. 341., 519. Az itteni ruténok az 1330-as években telepedtek meg a faluban. Betelepítésükben a Nagymihályiaké volt a főszerep. Engel 1985. 974.
} 
Úgy látszik, hogy Máramarosban a ruténok betelepítésében főleg a vlah eredetű Dolhaiak jártak az élen, az ismert szláv etnikumú telepek a család falvaiban találhatók. 1418-ban a fent már említett két kápolnával rendelkező beregi faluval együtt sorolják fel a Dolhaiak névadó birtokát is, Dolhát, amelynek egyháza szintén rutén hitú volt. Nyugati keresztény egyház viszont nincs a településen. Itt feltételezhetően románokkal kevert szlávság élhetett. ${ }^{209}$ 1441-ben Munkács vár tartozékaként van szó ruténokról Kusnica és Kerecke falvakban, amely két települést a Dolhaiak szereznek meg kenézségként (more et ad instar Keneziorum valachicalium). ${ }^{210}$ A két falu és Dolha is eleinte Bereghez, ám a középkor végén már Máramaros megyéhez tartozott. ${ }^{211} \mathrm{Az}$ itt, a falvak szomszédságában elterülő, 1461-ben említett „rutén föld” már teljesen bizonyosan etnikai színezetü jelzővel volt ellátva, csak az a kár, hogy arról nem számol be ez a forrás, voltak-e falvak ezen a területen, és ha igen, melyek voltak azok. ${ }^{212} \mathrm{~A}$ szakirodalom rutén lakosságúnak tartja emellett Bedőházát is. ${ }^{213} 1489$-ben pedig, amikor a huszti Theremi Albert 50 forintért 5 herincsei és két lipcsei telket vett zálogba, kiderül az oklevélből, hogy Herincsén az egyik funduson egy rutén pap élt. Ez alapján nyilván rutén híveknek is kellett ott lakniuk, már ha nem a keleti rítusú kereszténységre akart utalni az oklevél írója a „rutén” jelzővel. ${ }^{214}$ Ha a ruténok (vagy románok) meg is jelentek a mezővárosokban, minden bizonnyal gyorsan asszimilálódtak és beolvadtak az ottani magyarságba. ${ }^{215}$

A városlakók és a ruténok kapcsolata a források által tehát szinte egyáltalán nem adatolható. A mindennapokban nyilvánvalóan érintkeztek a ruténokkal, de olyan üzleti, birtokjogi, vagy egyéb vonatkozású ügy, amely oklevél kiadását kívánta volna meg, s így fennmaradhatott volna napjainkig, csak ritkán történhetett közöttük.

\footnotetext{
${ }^{209}$ Már. Dipl. 223.: „In predicta possessione Dolha... capellam ligneam ruthenorum cum cimiterio et sepultura" stb.

${ }^{210}$ Hunyadiak kora X. 296-297. és Már. Dipl. 372.

${ }^{211}$ Lásd erre Engel Pál középkorvégi birtoktérképét! Engel 2001. 1463-ban biztos, hogy még Bereghez tartoznak. Már. Dipl. 455. 1483-ban viszont már Máramaroshoz számítják őket. DL 38423.

${ }^{212}$ Már. Dipl. 457. 1461-ben, határjárás során említik: „viam de dicta possessione Kusnicza itur ad terram Ruthinorum".

${ }^{213}$ Bélay 1943. 40.

${ }^{214}$ „in qua quidam Rutenus presbiter ad presens resideret”. Már. Dipl. 597.

${ }^{215} \mathrm{Az}$ 1456-ban egy határjárásnál szereplő Nicolaus Orosz de Wysk esetében például valószínủleg erről van szó. Már. Dipl. 377.
} 



\section{A SÓBÁNYÁSZAT ÉS A VÁROSOK}

\section{A máramarosi sóbányászat és a sókamarák}

A só az egyik legfontosabb és legkeresettebb árucikk volt a középkori Európában, így Magyarországon is. Szerencsés módon, a Kárpát-medencében három területen is viszonylag nagy mennyiségben található meg ez az értékes ásványkincs. ${ }^{216}$

A királyi hatalom hamar felismerte, hogy a sókereskedelem révén komoly bevételekhez juthat. Már Szent István idején működtek királyi sóbányák a tordai sóvidéken, királyi magánbirtokokon. ${ }^{217}$ A királyi sógazdálkodásnak a termelés mellett már az Árpád-korban is a sóelosztás volt a másik fontos és ellátandó funkciója. ${ }^{218}$ A 14. század első harmadáig - a sóregálé kialakulásáig - azonban a só nem tartozott alapvetően királyi jog alá, ehelyett domaniális jelleggel bírt, azaz a mindenkori földesurat illette meg kitermelésének a joga. Az Anjou-korig ezért világi és egyházi kézben lévő bányákra is lehet adatot találni, bár utóbbiak meg sem közelítették a királyi bányák számát. ${ }^{219}$

\footnotetext{
${ }^{216}$ Ezek az északi, az erdélyi és a máramarosi sómezők, amelyek sorában Máramaros a második legnagyobb volt a só mennyiségét tekintve. Némedi Varga 1997. 26.

${ }^{217}$ Paulinyi 2005. 15.

${ }^{218}$ Az Árpád-kori sóbányászatra összefoglalóan: Zsámboki 1997. 47-55. A középkori magyarországi sótermelésre és az ezzel kapcsolatos királyi politika alakulására a szakirodalom eddigi eredményeinek részletes összefoglalásával lásd Draskóczy 2008. 147-161.

${ }^{219}$ Paulinyi 2005. 13-15.
} 
A 14. század folyamán lassan egyre inkább királyi monopólium alá kerülő sótermelésből és -kereskedelemből az uralkodónak komoly bevételei származtak. ${ }^{220}$ Főleg azután, hogy az erdélyi aknák mellett a máramarosi lelőhelyeken is megindult a termelés.

A fent elmondottak alapján könnyen belátható, hogy a máramarosi térség fejlődését milyen rendkívüli módon meghatározhatta az ott folytatott, a királyi pénzügypolitika miatt kiemelt fontosságú sóbányászat, amely hosszabb távon a létrejövő városok tartós királyi birtoklását és társadalmigazdasági fejlődésük sajátos alakulását eredményezte.

A korábbi szakirodalom szerint a sótermelés már a magyarság megjelenése előtti időkben megkezdődhetett Máramarosban. Vannak azonban olyan túlzó vélemények is, amelyek szerint egészen a római korig vezethető vissza a máramarosi sóbányák művelésének kezdete, s azóta az aknákat folyamatosan művelték. Akárhogy is nézzük, ezeken a korai lelőhelyeken részben a talajerózió miatt felszínre bukkant sórétegek kitermelése, részben pedig a sósforrások lepárlása folyhatott elsősorban, azaz szó sincs mélyművelésről és „nagyüzemi” sóbányászatról a 13. század végéig. ${ }^{221}$

A magyarság megtelepedése előtti máramarosi bányaművelés tehát kontinuus módon bizonyosan nem folytatódott az Árpád-kor folyamán, s az intenzívebb bányászat csak a 13-14. század fordulóján indulhatott meg, hiszen a terület korábban igen gyér lakosságú, szinte teljesen lakatlan volt.222 A megfelelő létszámú munkaerő csak a századforduló környékén, a hospesek betelepedésével állhatott rendelkezésre Máramarosban, $\mathrm{s}$ ezt igazolja az ebben a korszakban elnyert kollektív privilégium is. Így reálisan nézve, legkorábban talán a 13. század végén kezdődhetett el csak a sóbányászat. ${ }^{223}$

\footnotetext{
${ }^{220}$ A 15. század közepén a királyi sómonopólium már óriási, 80-100 ezer forintnyi bevételt jelentett éves szinten az uralkodónak. Ez Zsigmond összes bevételének nagyjából harmada, Mátyásénak durván hatoda volt. Igaz, ez a jövedelem a Jagelló-korban már csak a töredékét tette ki a Mátyás korában befolyó összegnek, talán 30000 forint lehetett éves szinten. Draskóczy 2005. 88-89; Draskóczy 2010. 52; Draskóczy 2014. 58. A sóbevétel ilyen hatalmas jelentősége a későbbiekben, az Erdélyi Fejedelemség idején is megmaradt. Oborni 2002. 73. Konkrétan a máramarosi kamara tiszta éves bevétele 1550 körül 8-10 000 forint körül mozgott. Uo. 93-94.

${ }^{221}$ Kovássy 1986. 627. Réthy-Tóth 2012. 12-15., 56-57.

${ }^{222}$ Valamivel korábbra, a 13. század elejére teszi a máramarosi sótermelés kezdetét Wenzel 1857. 13., 84; Wenzel 1880. 147. Egyértelmúen megkérdőjelezhetetlen adata azonban nincs rá. Szkeptikus viszont ezzel a korai bányanyitással kapcsolatosan Iványi Béla is. Iványi 1911. 13-14.

${ }^{223}$ Draskóczy 2014. 56. A bányászat igazi fellendülése valószínűleg csak Nagy Lajos idején történt. Draskóczy 2008. 150. A máramarosi sóbányászat középkori és későbbi történetének rövid áttekintése a fentiek mellett: Réthy 2005; Réthy - Tóth 2012. 52-59; Lásd még Wenzel 1857. 84-86.
} 
Habár a máramarosi sóbányászat munkaszervezete valószínűleg magyar eredetű volt, van olyan vélemény is, miszerint a sóbányák „modern” technikákkal történő, mélyebb művelésének megkezdése a frissiben betelepedő német hospeseknek és az általuk behozott új technológiai ismereteknek köszönhetően jelent meg Máramarosban. ${ }^{224}$

A máramarosi sóbányászatra vonatkozó első okleveles adataink a 14. század közepéről származnak. Az első ismert sóbányaemlítés a térségben 1355-ben történt, Gyulafalva és Nyíres határjárása kapcsán. Itt valószínüleg a Sugatag környéki sóbányákhoz vezető útról van szó. ${ }^{225}$ A legfontosabb sóaknák Máramaros megyében egészen a modern korig Técsőn, Rónaszéken, Aknasugatagon és Huszt mellett helyezkedtek el. A sóaknákat addig múvelték, amíg ki nem merültek. Ilyen értelemben a sóbányászat súlypontjai a területen belül folyamatosan változtak. Már a 15. század elején, 1418-ban is van adat a Sziget és Alsóróna közelében fekvő Veresmart mellett felhagyott sóaknára. ${ }^{226} \mathrm{~A} 15$. század közepén még Huszt, Técső és Rónaszék mellett folyt bányászat, de úgy tűnik, a Técső melletti aknák müvelését a század végére befejezték. A 16. század elejétől a sótermelés súlypontja egyre inkább a Rónaszék környéki aknákra tevődött át. ${ }^{227}$

A sóbányákat a környékbeli határjárások alapján lehet(ne) beazonosítani, de ezek az említések szórványosak és szűkszavúak voltak, így csak néhány helyen lehet általuk a bányászat helyszíneit dokumentálni.

1355-ben tehát, mint láthattuk már múködött az említett Gyulafalva vagy Sugatag melletti akna, Rónaszéktől délnyugatra. 1389-ben a Tisza fentebbi szakaszánál, Szarvaszó és Hosszúmező határában, az Avas mellett van egy aknához vezető út, amely talán szintén Sugatagra, esetleg Rónaszékre vezetett. Utóbbit személy szerint kevésbé tartom valószínứnek, hiszen az a folyó túlpartján helyezkedett el, a „sóbányához vezető út" kifejezésből viszont logikusan az következhet, hogy az akna valahol a közelben volt. 228

1405-ben felhagyott sóaknáról esik szó Bárdfalva környékén, Rónaszéktől nem messze. ${ }^{229} 1411$-ben Kökényes, Irholc, Nyeresznice és Uglya határjárása során Talaborfalva mellett, Visktől és Úrmezőtől észak-északkeleti irányban folyik sóbányászat. ${ }^{230}$ Ugyanazzal a határjárással összefüg-

\footnotetext{
${ }^{224}$ Draskóczy 2014. 57-58.

225 "quandam viam in fodinas salium ducentem". Már. Dipl. 36. Bélay 1943. 10.

${ }^{226}$ Bélay 1943. 7. Már. Dipl. 220.: „locum antiquae fodinae salium”.

${ }^{227}$ Réthy-Tóth 2012. 54; Glück 2013. 182.

228 "viam quae itur de Avas ad superiorem fodinam salium". Már. Dipl. 92.

${ }^{229}$ ",ad antiquas salis fodinas seu veteratas". Már. Dipl. 134. Felvethetö, hogy talán ez ugyanaz az akna lehetett, amelyet Gyulafalva határjárásában említettek 1355-ben, és amelyet akkor még műveltek.

230 „in loco Thalaborsowa vocato a foveis seu salifodinis ibidem habitis”. Már. Dipl. 171.
} 
gésben ugyanakkor említenek ettől nem messze, valahol Técső közvetlen közelében egy „régi”, azaz elhagyott sóbányát. ${ }^{231}$

1414-ben Rónaszék szomszédságában, Disznópatak mellett van szó sóaknáról. ${ }^{232} \mathrm{~A}$ következő adat a már említett, Veresmart határában lévő bánya Rónaszék mellett, amely 1418-ban már nem üzemelt. 1460-ban viszont működő sóaknáról van hírünk egy határjárásban, Sziget, Disznópatak és Rónaszék között. Ez valószínűleg az 1414-ben is említett bányahely lehetett. ${ }^{233}$ Van még ezeken kívül egy okleveles említés arra, hogy talán Huszt mellett is lehetett sótermelés, de az 1480. évi oklevél megfogalmazása alapján itt a fodina kifejezést akár a kamarára vonatkoztathatták, de tudjuk azt, hogy itt valóban volt akna a korszakban. ${ }^{234}$ Végezetül helynév is utal ugyanitt sótermelés helyszínére. A Huszttól északra fekvő Iza falu határjárásában 1390-ben említik Husztaknát, ami valószínűleg a mezővárostól keletre található Sófalva közelében lehetett. ${ }^{235}$

Ha a térképre vetítjük a fenti oklevelekben olvasottakat, akkor azt látjuk, hogy a 14-15. század fordulóján legalább négy nagy gócpontja bizonyosan volt a sótermelésnek Máramarosban: az ismert aknák Huszttól északkeletre, Técső (Talaborfalva mellett, a Tisza jobb partján), Hosszúmező (Szaplonca mellett, a folyó déli partján) és Sziget (Disznópatak és Rónaszék mellett a jobb parton; valamint Veresmart, Gyulaháza mellett a bal parton) környékén találhatók. A Hosszúmező közelében lévő, Talaborfalva környéki sóterrmelés valamivel később, a század közepén is bizonyosan folyt, hiszen szó esik itt ekkor egy határjárásban a várossal szemközti sókikötöről, ahol nyilvánvalóan a Talabor-patak melletti aknák sóját rakodták hajóra. ${ }^{236} \mathrm{~A}$ középkor végén viszont, amikor 1516-ban a Perényi-féle zálogbirtoklás feltételeit írásba foglalták, a szerződés beszámol arról is, hogy a sóhajókat Huszton, Szigeten és Becsen (a mai Tiszabecsen) szokták megrakni, azaz szó sincs már az említett, Hosszúmező melletti sókikötőről. Ez talán a Talabor-patak melletti aknák kimerülésének lehet az egyik jele. ${ }^{237}$

\footnotetext{
231 „veteres foveas seu salifodinas vulgo Soakna vocatas". Már. Dipl. 172.

${ }^{232}$ Elég pontosan meghatározzák a helyét, tudjuk azt is, hogy a faluból vezet hozzá egy közvetlen út: „quandam viam de dicta possessione Disznopataka ad salis fodinas ducentem”. Már. Dipl. 196.

${ }^{233}$ DL 15428: „regalibus fodine Rona”.

${ }^{234}$ DF 285466: „,nobili magistro Alberto vicecamerario fodine Hwzth”.

235 „ad unam stratam publicam quae ducit ad Huzthokna”. Már. Dipl. 101.

${ }^{236} \mathrm{Az}$ 1456. évi határjárás vonatkozó része (a Hosszúmezőtől nyugatra fekvő déli folyópartról kiindulva): „et abinde ascendendo per Tyciam per longum meatum ad fluvium Dubinyapathaka, ab hinc ascendendo ad portum salis per quasdam vias". Már. Dipl. 378-379.

${ }^{237}$ Perényi 791. sz.
} 
1397-ben Zsigmond országos sóügyrendezést hajtott végre, amelyben széles körủen szabályozta az ország sóellátásával kapcsolatos kérdéseket, így például új kamarákat hozott létre, meghatározta az egyes kamarák által sóval ellátandó területet vagy a sókockák árát is. A rendelkezés a máramarosi bányákat is megemlíti. Egyrészt előírta, hogy a só ára Vízaknán és Máramarosban mázsánként 100 dénár legyen, másrészt parancsa szerint a máramarosi kamarának a Zagyva és Tisza folyók közti területet kell ellátnia az értékes ásványkinccsel. Máshol az erdélyi só került eladásra, a Szávától délre viszont engedélyezték a tengeri só forgalmát is. ${ }^{238}$

A só árát a bányahelyeken 100 kockánként 1 forintban határozták meg, de minél messzebb megyünk nyugatra, úgy nőtt az ára: így Vasváron vagy Sopronban akár az 5 forintot is elérhette. A sókockákról amúgy ebben a korszakban kevés adatunk van. Súlya és mérete helytől függően változhatott. 239

Az 1397. évi reform végezetül egy kézben összpontosította a királyi sóigazgatást. A rendszer élére az erdélyi sókamaraispán került. Ozorai Pipo még országos sókamara-ispáni címet viselt, 1426. évi halálával azonban megszűnt a sóbányászat ilyen szinten központosított igazgatása. Majd csak 1438-ban állt újra vissza a régi rend a központi sóigazgatásban, s innentől a sókamarák újra egy kézben vannak. ${ }^{240}$

Gyakran előfordult egyébként, hogy emellett a harmincadispán címet is viselte a sókamaraispán, hogy ellenőrizni tudja a sóbehozatali tilalom betartását. ${ }^{241}$ Ez főleg a mind nagyobb mennyiségben hazánkba érkező lengyel és orosz só („,Kwk-só”) miatt volt fontos. ${ }^{242}$

${ }^{238}$ Iványi 1911. 14. Draskóczy 2004. 289-291; Az oklevél jelzete: DL 8861. Kiadta Wenzel 1880. 436-439.

${ }^{239}$ A sókockákból alapjában véve két típus volt forgalomban: a hajósó (sales navales) és a kocsisó (sales currules). A középkorban a kockák súlyát pontosan nem ismerjük, a hajósó kockái valószínúleg 10-12 fontot (5-6 kg) tehettek ki. A kocsisó ennél nagyobb volt. A dolgot bonyolítja, hogy méretük helyenként eltérő volt. Draskóczy 2010. 54-55; Draskóczy 2014. 60. A 16. században Tordán ezek súlya a nagyjából fél kilogramot kitevő magyar fonttal mérve 5 és fél, illetve 7 és fél font volt, de Vízaknán 10 és 22 fontot nyomtak. 1552-tőll a sókockák súlya tovább nőtt az erdélyi kamaráknál. Oborni 2002. 88-89; Bogdán 1991. 446-447., 482-483. A sószekerek általában 5-16 mázsát, a sóhajók 60-100 tonnát voltak képesek elszállítani. Draskóczy 2014. 61.

${ }^{240}$ Draskóczy 2011. 149. Így példának okáért 1478-ban gyakorlatilag mindenféle bányaügy egy kézben összpontosult, Nagylucsei Orbán irányítása alatt. DL 18106 (1478): „Urbani universarum camerarum salium regalium ac aurifodinarum regni Hungarie". Draskóczy 2009a. 105., 2. jegyzet.

${ }^{241}$ Pap 1909. 42; Draskóczy 2014. 58-59.

${ }^{242} \mathrm{~A}$ lengyel (és orosz) só máramarosi só kárára történő behozatalát ezért általában akadályozták. Erre példaként lásd V. László parancslevelét 1457-ből, melyben tiltja az ilyen só forgalmazását. A tiltás tárgya: „ex introduccione salium Polonicalium ac etiam aliorum salium de Ruscia wulgo Kwk". Már. Dipl. 398. A kassai kamara a 15. században rendszeresen fellé- 
A máramarosi sókamara működéséről csak a 14. század végén ismeretesek az első információink. Amikor a huszti uradalmat megszerezték a Béltekiek, 1397-ben létrehozták- az ugyanezen évi, fentebb ismertetett országos sóigazgatási reformmal összefüggésben - a máramarosi sókamarát is. A kamarákat a birtok visszaszerzése után, azaz a 15. század elején sem csatolták már vissza az uradalomhoz, erre csak 1435-ből van adatunk, ettől kezdve ugyanis a huszti várnagyi és a sókamara-ispáni tisztséget sok esetben ugyanaz a személy töltötte be. ${ }^{243}$ Új fejlemény, hogy a Huszton székelő sókamaraispán egyre inkább a máramarosi ispáni címet is viselte a 15. században. ${ }^{244} \mathrm{~A}$ kamaraispánok a középkor végén mindinkább bekapcsolódtak a sókereskedelembe, attól függetlenül, hogy bárókról vagy középnemességről van-e szó. Perényi Gáborról, Sárkány Ambrusról, de a kevésbé előkelő Csebi Pogány Zsigmondról is ismeretes ez a tény. ${ }^{245}$

A sókamara központja tehát Huszton volt. Ennek alárendelt bányakamarái Huszt mellett és Rónaszéken helyezkedtek el. Utóbbinak a központja egy kisebb jelentőségű erődítmény volt. ${ }^{246} \mathrm{Ez}$ azonban Huszt árnyékában érzékelhetően alárendelt szerepet játszott a kamara szervezetében, gazdasági értelemben véve bizonyosan Huszttól függött. ${ }^{247}$

A sókamaraispán legtöbbször Máramaros ispáni címét is viselte, ezzel szemben a rónaszéki castellumban tartózkodó kamaraispán-helyettes logikus módon olykor megyei alispáni tisztséget töltött be. ${ }^{248}$ Néha van adat egyszerre két kamaraispánról, s ilyenkor egyikük nyilván Rónaszéket felügyelhette. A huszti és rónaszéki várnagyokra vonatkozó említéseink is igazolják azt, hogy az ispáni, kamaraispáni és várnagyi tisztség sokszor összefonódott. ${ }^{249}$ De mégis: alapesetben a comes - camerarius mellett a he-

pett a lengyel só forgalma ellen. Bártfa I. 2913. sz., 3225. sz., 3288. sz. stb. De például 1471-ben időlegesen feloldják ezt a tilalmat. Bártfa I. 1837. sz. Összefoglalóan lásd Draskóczy 2009b.

${ }^{243}$ Csánki I. 451; Engel 1977. 180-181.

${ }^{244}$ Például Szentgyörgyi Vince László 1436-ban (DL 38585), Pöstyéni Mihály 1451-ben (DL 38130) stb.

${ }^{245}$ Kubinyi 1994. 299. 71-72. jegyzet.

${ }^{246}$ A rónaszéki castellumot például 1468-ban említik. Csánki I. 444; Pap 1909. 45-46. 1523ban is szerepel az erősség oklevélben. DL 32598: „castrum nostrum Hwzth, unacum fodinis salium, castellum Rhona, oppidis, possessionibus et bonis universis" stb.

${ }^{247} 1448$-ban a rónai sókamarából a sókamaraispánnak levelet küldő Benedek deák pénzt és hajóépítőket kért. DL 44501. Iványi 1911. 21.

${ }^{248}$ 1476-ban egy királynéi parancslevél címzettjei: „magnifico Francisco de Paladi presenti comiti et camerario Marumarosiensi, et aliis omnibus et singulis eiusdem comitatus ac camere futuris camerariis, comitibus, vicecomitibus et vicecamerariis" stb. DL 17809; "Nos Andreas de Bol vicecomes fodinarum salium de Rona, vicecomes similiter comitatus Maramarosiensis". 1504. június 11. Az oklevél elveszhetett, mivel a levéltári adatbázis jelenleg nem tartalmazza. Teleki gyömrői 430. sz.

${ }^{249} 1474$ (Huszt és Róna): „Nos Ladislaus Magnus castri Huszt et Paulus Magnus castelli de Ronaszek necnon comites terre Maramorosiensis". Már. Dipl. 522; 1475 (Huszt és Róna): „Nos Michael castri Huszth et Paulus Magnus castelli de Ronaszek castellani necnon vice- 
lyettes a vicecomes - vicecamerarius tisztségeket viselte, s mindehhez társulhatott még olykor a várnagyi tisztség is.

A kamaraispánnak széles feladatköre volt: ő irányította a kamara pénzügyi igazgatását és a máramarosi ispánnal közösen (már ha éppen nem egy és ugyanazon személy töltötte be mindkét tisztet) bírói joghatóságot töltött be a területen, ami 1498-tól minden só- és hajózási ügyre, de a sókamara területén személy szerint is mindenkire kiterjedt. ${ }^{250}$

Nem térhetünk ki részletesen a kamaraispánok személyére, de egy kitünő példát azért érdemes megemlíteni. Ez alapján mind a kamaraispáni cím betöltésének elvei, mind a kamaraispánok személyes motívációja, illetve az ebben a karrierben rejlő lehetőségek láthatóvá válnak.

Ismerünk egy itáliai származású famíliát, a Maniniket, amelynek öszszesen hat tagja tevékenykedett Magyarországon a 15. században. Angelo, Odoardo, Pape, János, Márk és Ferenc - mindannyian testvérek - közül több is szerepet játszott a királyi sókamarák működtetésében. Pályájuk jól mutatja, hogy Zsigmond uralkodásától kezdve a sókamaraispáni tisztséget sok esetben már valódi pénzügyi szakemberek töltötték be. ${ }^{251}$

Közülük Angelo 1424-ben dési sókamarás, 1442-ben királyi familiárisként szerepel, 1447-ben máramarosi sókamarás, 1459-ben dési, 1460-ban széki kamaraispán. Pape 1436-ban kerül át dési kamarásként Szalárdra, ahol sókamaraispán lett. 1440-ben, 1441-ben dési sókamarás 1444-ben széki, 1449-ben és 1459-ben dési. ${ }^{252}$

Odoardo 1447 áprilisában még budai, júliusban már dési sókamarás, 1448-ban széki és máramarosi, 1450-ben máramarosi sókamarás és ispán egyszerre, mégpedig testvérével, Angelóval együtt, 1455-ben újra Désen találjuk. ${ }^{253}$ 1458-ban Odoardo már halott, özvegye Kállói Lökös Jánoshoz ment hozzá. ${ }^{254}$

comites terre Maramaros”; 1487 (Huszt és Róna): „Nos Stephanus castri Huszt, et Ioannes castelli Rona Castellani”. Már. Dipl. 587; 1488 (Róna): „Nos Ambrosius castelli Rona castellanus". Már. Dipl. 593.

${ }^{250}$ Ezekről a kérdésekről nagyon részletesen beszámol Iványi 1911. 16-20.

${ }^{251}$ A testvérekre összefoglalóan lásd Wertner 1913. 71-72. A család magyarországi tevékenységét Draskóczy István foglalta össze részletesebben. Draskóczy 1994. 129-131.

${ }^{252}$ Angelo: DL 27154 (1424); DL 36390 (1442); DL 44490 (1447); DL 36392 (1459); DL 36392 (1460); Pape: DL 55060 (1436); DL 36390 (1440, 1442); DL 55236 (1441); DL 65410 (1444); DL 36391 (1449); DL 36392 (1459).

${ }^{253}$ Odoardo: DL 55352, DL 55358 (1447); DL 44501, DL 55384, Zichy IX. 204. (1448); DL 24761. Kiadása: HO VII. 466., DL 38609, DL 38298 (1450); DL 36403 (1451, 1458); DL 36407 (1454); DL 36407 (1455); DL 36407.

${ }^{254}$ DL 55618. 
Odoardo és Angelo, ahogy láttuk, 1450-ben együtt viselik a máramarosi ispán és kamaraispán címet. Odoardot testvéreivel együtt Hunyadi János kormányzó ugyanebben az évben nemesi címmel látta el. ${ }^{255} 1450$ ben megkapják a bihari Szentpéterszeget, ahol a pallosjogot is bírják. ${ }^{256} \mathrm{Az}$ 1450-es, 1460-as években a törzsbirtokukhoz közeli Gáborjánban, Tótfaluban, Apátiban és Boldogasszonyfalván is birtokolnak. ${ }^{257}$ Angelo 1453-ban Szatmárban házat és mészárszéket vásárol 55 forintért, 10 évvel később pedig még mindig szatmári háztulajdonosként említik. ${ }^{258}$ Logikusnak tünik, hogy ott is hivatalt viselt a sóigazgatásban, bár erre adatunk nincs.

1455 és 1457 között a három fivér közül már Angelo volt a máramarosi ispán, Erdélyi Lászlóval együtt. 1459-ben ugyanő az összes királyi kamara igazgatója Szapolyai Imre litterátussal közösen. ${ }^{259}$ 1462-ben Angelo és Pape fiai Szatmár megyében tettek osztályt, majd a következő évben a család tagjai megegyeztek a hagyatékot illetően. ${ }^{260}$ Pape az 1450-es évek közepén előtt halálozik el, két fiút hagy hátra, 1463-ban pedig már Angelo is halott, adósaik jegyzékét ekkor összeírják. ${ }^{261}$ Ezután is több forrás van a családra nézve, de ők már - az egyetlen Pape fia Pál kivételével, aki az 1460-as években még utoljára a máramarosi kamarák élén állt - nem játszanak szerepet a máramarosi kamarákban. ${ }^{262} \mathrm{~A}$ család tagjai tehát egy másfél generáción keresztül rendszeresen váltogatták egymást a környékbeli sókamarákban.

A kamarákból két típus működött az országban: a bányakamaráknál termelés és árusítás is folyt, az ország belsejében lévő kamarák viszont árusítást végeztek. A régióban tucatnyi kamara müködött, amely részben a máramarosi, részben az erdélyi só forgalmazásával foglalkozott. ${ }^{263} \mathrm{~A}$ bányáktól távolabb lévő kamarák közül az észak-alföldi és az attól északra lévők - az erdélyi és máramarosi sókamarák korábbi felosztásának megfelelően - a máramarosi kamara által ellátott területhez tartoztak. Elsősorban a Tisza felső folyásánál fekvő poroszlói, luci és tokaji kamarára kell gondolnunk. Szintén máramarosi sót forgalmazott a kassai és a Mátyás által

\footnotetext{
${ }^{255}$ DL 38298, DL 24761.

${ }^{256}$ DL 14342, DL 14344.

${ }^{257}$ Csánki I. 640. Károlyi II. 323.

${ }^{258}$ DL 24958, DL 55766.

${ }^{259}$ Wertner 1913. 71-72.

${ }^{260}$ DL 55744, DL 55745, DL 55750.

${ }^{261}$ DL 55767, DL 36392, DL 55697, DL 55698. A 166 adós több mint 1400 forinttal tartozott Angelonak és Odoardonak. Draskóczy 1994. 131.

${ }^{262}$ Draskóczy 1994. 130.

${ }^{263}$ Draskóczy István felsorolja őket: Szalacs, Szalárd, Várad, Szolnok, Abád, Poroszló, Luc, Tokaj, Becs, Szatmár. Draskóczy 2011. 150.
} 
1472-ben megszüntetett eperjesi sókamara. ${ }^{264}$ Van azonban még egy kamara, amely biztosan filia volt, ez pedig a szikszói. 1472-ben ugyanis, amikor Mátyás a Putnoki Radnót felé fennálló 200 forintnyi tartozását a szikszói kamarából kiutalandó sóval kívánja törleszteni, említést tesz arról, hogy a szikszói kamarás Kinizsi Pál máramarosi sókamarás alkamarása volt. ${ }^{25}$

A máramarosi só egyik legfontosabb kirakodóhelye Poroszló volt, ahonnan szekerekkel Eger felé lehetett továbbszállítani a „fehér aranyat”. 1512-ben és 1523-ban is oly módon beszélnek ugyanis a máramarosi sóhajók érkezéséről, mint ami teljesen szokványos, szinte "menetrendszerü" dolog volt. ${ }^{266} \mathrm{~A}$ sókamarából rendszeresen utalhattak ki sót a környékbeli filiákba. 1494-ben Beatrix királyné parancsa alapján a kassai kamarába 4000 sót, a becsi kamarába 2850 sót kellett szállítani. A viteldíj nem volt olcsó, előbbi esetben 2320, utóbbi esetben 570 sót fizettek a szekereseknek a fuvarozásért. ${ }^{267}$

A királyi sómonopólium és a sókamararendszer 1521-ig működött ebben a formában az országban, amikor II. Lajos az egyre nagyobb mértéküvé vált pazarlásra hivatkozva megszüntette azt. Ennek keretében feloszlatta azokat a sókamarákat, amelyek nem a bányáknál üzemeltek, hanem az ország belsejében, és bevezette a szabad sókereskedelmet. A kamarák nem müködtek ugyanis valami hatékonyan, a sótermelésben és -szállításban részt-vevők rendszeresen nagy mennyiségü sóhoz jutottak onnan, amit maguk értékesítettek, de a kamarákból a király is gyakran utalványozott ki nagyobb mennyiségű sót. ${ }^{268}$

${ }^{264}$ A kassaira sok adatunk van, főleg a bártfai levéltár oklevélanyagában. Lásd például Bártfa I. 2723. sz. és Eperjes 493. sz. Az eperjesi sókamara nem állhatott fenn túl régóta, amikor megszüntették, mivel 1458-ban Mátyás a bártfaiaknak nem innen (ami logikusabb lenne), hanem a rónai kamarából utaltat ki 500 forint árú sót. Azaz, lehetséges, hogy akkor még nem létezett az itteni filia. DF 213728. Ha mégsem így van, akkor talán a kamara forgalma nem tette lehetővé azt, hogy ekkora mennyiséget kiadjanak onnan.

${ }^{265}$ DL 90150. A királyi oklevél címzése: „fideli nostro egregio Paulo Kynysy comiti camerarum salium nostrorum Maramorosiensium aut eius vicecamerario in camera Sykzo".

${ }^{266}$ 1512-ben a volt máramarosi ispánnak nem adja ki Perényi Gábor sókamaraispán azt az 1000 forint értékű sót, amelyet II. Ulászló parancsa alapján Poroszlón, a Máramarosból érkező hajókból kellett volna kiszolgáltatnia. Perényi 761. sz; 1523-ban, amikor Mária királyné bérbe adja Ártándi Pálnak Husztot a sóbányákkal, többek között azt is kiköti, hogy a 7000 forint bérleti díj mellett 1500 forintnyi sót is adnia kell, amelyből 1000 forintot a poroszlói kamarába évente először odaérő sószállítmányból kell teljesítenie: „Sales autem pro mille florenis singulis annis in camera nostra Porozlo ex navibus que primitus istic salibus onerati adducentur ad manus hominum maiestatis nostre ad id deputatorum dare, connumerare et persolvere teneatur." DL 32598.

${ }^{267}$ DL 98434: „,item ad cameram Cassovie cum curribus salium 4000, et curriferris pro conductione 2320, ad cameram Bechy cum curribus salium 2850, curriferis (!) 570".

${ }^{268}$ Glück 2008. 14., Draskóczy 2005. 86-91. 1494-ben a máramarosi kamara termelésének csaknem felét az üzemeltetés költsége emésztette fel, szűk ötödét pedig utalványokra adták ki. Draskóczy 2014. 64. 


\section{A sóbányák személyi állománya}

A sóbányászat erőteljes nyomot hagyott a máramarosi térség városfejlődésén. A bányák megnyitása munkalehetőséget és viszonylagos népességkoncentrációt eredményezett, a kitermelt só elszállításának feladata pedig intenzíven bekapcsolta Máramarost a vízi és szárazföldi tájközi áruforgalomba. A helyi lakosság számára ezért a sókamara állandó jövedelemforrásként szolgált, de a sóigazgatással kapcsolatos szükségletek ellátásából a környékbeli parasztság is kivehette a részét, s juthatott ezzel további bevételekhez. A sókamara és a huszti uradalom a legnagyobb „munkáltató" és felvásárló is volt egyben a környéken.

Természetesen a máshol megszokott személyek is szerepet játszhattak az uradalom, a bányák és a kamara müködtetésében. ${ }^{269}$ Minden bizonnyal az uradalom alkalmazta például a huszti vámszedőket. ${ }^{270}$ 1431-ben hallunk arról, hogy egy nemest az Apsaiak közül az Odwarbyrow megkülönböztető névvel nevezték meg. Elképzelhető - amennyiben nem valamelyik környékbeli nemesi uradalomban betöltött tisztségének köszönhető a neve - hogy a huszti uradalomban betöltött pozicióját mutatja a sajátos megkülönböztető név. ${ }^{271} \mathrm{~A}$ várnagyokról fentebb már esett szó. Amennyiben a várnagyok nem viselték egyúttal az ispáni vagy alispáni címet, nyilvánvalóan a sókamaraispán familiárisai voltak.

A sókamara müködtetéséhez a legkülönfélébb képzettségü munkaerőre volt szükség. Ilyen munkások voltak többek között a sóvágók, a kerekesek, a gépelyesek, a kovácsok, a fürdősök, de mindezek mellett még további különféle, ezeknél kvalifikáltabb tisztségek betöltésére is lehetőség volt a kamaránál, mint a sigillatori, a számtartói, sószámlálói vagy az írnoki. A máramarosi sókamara különféle alkalmazottai - s ez még inkább igaz a sóvágókra - nem a környék falvaiban, hanem főleg a városokban éltek, és általános vélemény szerint a 15 . századra már főleg magyarok lehettek. ${ }^{272}$

${ }^{269}$ Összefoglalóan: Iványi 1911. 21-23. Fizetéseikre lásd uo. 26-29; Takáts 1929. 70-74. A bányákban dolgozó fizikai munkásokra 1553. évi adatok alapján: Bélay 1943. 33-34.

${ }^{270}$ Máramarosban a korai és már említett viski vám és az öt mezőváros kiváltságlevélben szereplő vásárvámjai mellett a huszti vámról a 15. századból, az 1435. évi sóbányastatútumból van adatunk. DF 212979: „, ad locum tributi in civitate nostra Hwzth”. Hogy nem a már ismert vásárvámról, hanem állandóan működő vámról lehet szó, a „,vámhely” kifejezés mellett abból is látszik, hogy vámházról is szó esik benne: „ad predictas domos plebani et tributarii”. stb. Talán Szigeten is lehetett hasonló: 1479-ben János litteratus, szigeti "theoloniator" kerül említésre, mégpedig Dési Péter máramarosi ispán familiárisaként, akit a huszti és rónaszéki várnagyokkal közösen sorolnak fel egy 1479. évi oklevélben. Teleki gyömrői 316. sz.

${ }^{271}$ Már. Dipl. 286.: „Petro filio Nicolai Odwarbyrow de dicta Alsowapsa”.

${ }^{272}$ Takáts 1929. 70; Bélay 1943. 30. Az 1435. évi statútum is városlakóként beszélt róluk: „,incole et inhabitatores civitatum nostrarum predictarum ac alii salium incisores". DF 212979. 
Ha a kvalifikáltabb, mondjuk úgy, „,szellemi foglalkozású" dolgozókat nézzük, van adat például sigillatorra, ${ }^{273}$ és a számtartói feladatot ellátó rationalisra is. ${ }^{274} 1498$-ban említik Tárcai János sókamaraispán huszti sótisztjeit (faktor), Ilmeri Pál deákot és (Barilovics) Dolgos Miklóst. Utóbbi oklevélből az is kiderül, hogy a sókamara fontosabb pozíciókat betöltő alkalmazottai a kamaraispán familiárisai voltak. ${ }^{275}$ Beatrix királyné 1494. évi utasítása, amelyet Csebi Pogány Zsigmond máramarosi és kamaraispánnak címzett, annak jelentésére válaszul szintén arról árulkodik, hogy a kamaraispán familiárisai ültek a fontosabb poziciókban. Ezek: a két várnagy, a négy alkamarás és faktor. ${ }^{276} 1515$-ben van ismeretünk ezen kívül a rónai kamara idegen (forensibus), nemesi státusú jegyzőjéről, akinek Szigeten egyébként háza is volt. ${ }^{277} \mathrm{Az}$ írnokokból az 1510-es években, a Perényi-zálog idején kettő volt, egy a zálogbirtokosé, egy pedig királyi. ${ }^{278}$

A sóvágók annak ellenére, hogy a városokban laktak, jogilag külön csoportot alkottak, hiszen élükön a három általuk lakott városban, azaz Huszton, Técsőn és Szigeten is egy-egy saját bíró állt, akinek részvétele nélkül a mezővárosi bírák nem ítélhettek felettük. Emellett adómentességet is élveztek. ${ }^{279}$

A sóvágók járandósága a 15-16. századi Erdélyben és Máramarosban röviden összefoglalva a következőképpen festett. A só kitermelését kézi erővel végző munkások részben bérmunkásként dolgoztak, a posztósok élén pedig saját bíró is állt. Két csoportjuk különböztethető meg a korabeli forrásokból Magyarországon, mind Erdélyben, mind Máramarosban. Egyiket egy évre fogadták fel (posztósok), a többiek alkalmi munkások

${ }^{273}$ DL 17804; DL 98434. Ő volt az, aki elvette a fuvarosoktól a só jogszerű eredetét igazoló, minden bizonnyal a sóbányáknál a sóval együtt kiállított cédulákat és ezután saját pecsétjével egy új iratot állított ki számukra, ami lehetővé tette a só továbbszállítását. A beszedett cédulákat ezután az elszámolásig lezárt ládában őrizték. Perényi 791. sz.

${ }^{274}$ 1506-ból ismerjük például Sebesi Tamást, a rónai sókamara rationalisát, akinek Nagybánya városa pénztartozás ügyében írt. A címzés: „Egregio Thome de Sebes rationali camere salium de Rona". DL 64506. A kifejezés Bartal szerint a procuratorral egyenértékü. Bartal 555. Valójában számtartó volt, ezek felügyelték az írnokokat (scriba), akik a számadásokat írásba foglalták. Iványi 1911. 21.

${ }^{275}$ DL 71072: „Paulo litterato de Ilmer, in castro Hwzth constituto, Nicolaus Dolgos factores de Hwzth, familiaribus egregii Johannis Tharczay camerarii Maramarusiensis". Regesztája: Perényi 689. sz. Barilovicsról még lesz szó.

${ }^{276}$ "Quod universis familiaribus pro ipsorum servitiis: duos castellanis, quatuor et totidem vicecamerariis et factoribus de Hwzth et Zygeth". stb. DL 98434. Javadalmaik összesen 21 666 kockára rúgtak.

${ }^{277}$ Egy szigeti házadásvétel során a szomszédok között sorolják fel: „Sigismundo litterato de Checher notario de Rona forensibus". DF 212593. A Csicseriek jól ismert, ungi eredetû köznemesi família.

${ }^{278}$ Perényi 791. sz.

279 "tribus iudicibus incisorum videlicet Hwzth, Thechew et Zygeth commorantium". Már. Dipl. 617. Másik elnevezésük az aknabíró volt. DL 44501 (1448). „iudex akne”. 
voltak (vendégvágók). Az első csoport helyzete kedvezőbb volt: járt nekik posztó, felfogadásukkor bor, Erdélyben, a tordaiak 1471. évi kiváltsága szerint emellett napi egy sókocka és segélypénz is. Bérük általában 100 kockánként 10 dénár, így napi keresetük az egyházi ünnepek miatti heti átlag 5 munkanap mellett 5-8 dénárt tehetett ki. A vendégvágóknak 8 kősó és 2 tömlő darabsó járt 100 kockáért. Úgy látszik, hogy a posztósok a 16. századra már úrbéri keretek között végezték a sótermelést, szolgáltatásuk a kamara felé kötelező jellegű volt, de nem ingyenes, azért fizetséget kaptak. ${ }^{280}$

Ismertek még ezeken kívül a fizikai munkát végző kerekisták. Ezeket Tordán millyéseknek nevezték. Feladatuk az aknából kiemelendő málhák sóval való megtöltése volt. A 17. század elején 1-2000 kősó után kaptak 70 dénárt. A sóhordók évente 3 forint segélypénzt kaptak, a máglába rakott sót megszámláló máglások Vízaknán egy máglasó után 10 forintot. Emellett voltak még a munkaszervezetben töménysóval dolgozó töményesek, a csigákat javító és a málhát felvontató gépelyesek is a sóbányáknál. ${ }^{281}$

A máramarosi só fő szállítási útvonalai már a középkor folyamán kirajzolódtak, és főleg az Észak-Alföldön bonyolult hálózatot alkotva kötötték össze a bányavidékek és a távolabbi települések sólerakatait (ilyenek voltak a térségben többek között Szalacs, Debrecen és Szolnok). Ennek a legfontosabb ágai a Huszttól Ungváron keresztül a felső-magyarországi civitasokba, a Tokajon keresztül Zsolna irányába, illetve a Szatmár felé haladó útvonalak voltak. Hasonló képet mutat egy 16. század közepi forrásunk is. 1547-ben összeíratták a máramarosi só kereskedelmében szerepet játszó vámokat. Az így kirajzolódó útvonalak a középkorra nézve is érvényesek lehettek. Az egyik Kassán keresztül a Szepesség felé haladt, a másik Tokajon keresztül Nyitráig, a harmadik az Ipoly-vidéken keresztül érte el a Nyugat-Felvidéket, míg a negyedik Tokajon át haladt Eperjes felé. ${ }^{282}$ A máramarosi só tehát közvetetten az ország távolabbi területeire, Északnyugat-Magyarországra, vagy éppen Szegedre is eljutott.

A szállítás legfőbb útvonala a Tisza volt, miután a sószállítmányt például a már említett, Hosszúmezővel szemközti kikötőben - behajózták, főleg a három, Tisza partján fekvő sókamarában rakodták ki, ahonnan szekerekkel szállították tovább. Így a máramarosi só elosztása a középkori Magyarország északi-északkeleti területeit többé-kevésbé lefedhette. A hajósót a sóhajókkal a cellérek vagy más néven celeristák szállították.

\footnotetext{
${ }^{280}$ Takáts 1929. 71-72; Draskóczy 2014. 61; Glück 2013. 83-84.

${ }^{281}$ Iványi 1911. 22-23; Takáts 1929. 72-74; Bélay 1943. 34; Draskóczy 2010. 53-54.

${ }^{282}$ Glück 2008. 24-35; Réthy - Tóth 2012. 87-90.
} 
Olykor a sót szállító szekereseket is így nevezték. ${ }^{283}$ A 8-10 ökörrel húzott sószállító szekerekkel általában a sókamarák környékén fekvő falvak parasztsága végezte a só szállítását. ${ }^{284}$

A helyi lakosság tehát sokat profitált a sóbányászatból, amely bevétel egy része közvetlen módon, azaz készpénzben, egy másik része viszont főleg sókockában jelent meg. Az uralkodó ugyanis sok esetben kősó kiutalásával teljesítette különféle helyi vagy egyéb fizetési kötelezettségeit, többek között a sóvágók részére, de gyakran adományozott is belőle, s ezzel a helyiek sókockák tömegéhez juthattak, amelyet később értékesíthettek. Az 1435. évi rendezésig a sóvágók a munkabér, jutalom vagy bármely más úton szerzett sóval szabadon kereskedhettek, a rendezés után azonban már csak a kamaraispán hozzájárulásával tehették meg ezt. A sókockákkal való kiskereskedelem ennek ellenére végig megfigyelhető a térségben, sőt a kora újkorban - a királyi sóelosztó-hálózat háttérbe szorulásával - már sokkal nagyobb mértékű, mint korábban. ${ }^{285}$

A sóbányászat belső szabályozására nézve két, Máramarosra vonatkozó királyi statútum is fennmaradt a korszakból. Ezek kitérnek a sóbányászok fizetségére és egyéb jutattásaira is, de a városfejlődés szempontjából legfontosabb részeik mégis csak azok voltak, amelyek a helyi mezővárosi önkormányzatra gyakoroltak hatást.

Nagy vonalakban tekintsük át, hogy milyen rendelkezéseket tartalmaztak ezek a statútumok. Az első ilyen a Luxemburgi Zsigmond által 1435. október 18-án elrendelt sókamarai szabályozás volt. ${ }^{286}$ Kibocsátásának oka az oklevél alapján az a felelőtlen és pazarló magatartás volt, amelyet a sókamaraispánok a só kiszolgáltatásával és a munkabérek terén tanúsítottak. A dokumentum részletesen szabályozta a sókamara ispánjának bírói és igazgatási feladatait, megtiltotta, hogy bárki a sókamaraispán engedélye nélkül sót adjon el a területen, továbbá tilalmazta a sóvágók által „tur"-nak nevezett, szervezkedésre és bérmegmozdulásokra lehetőséget teremtő gyűléseket is. Azt is deklarálták, hogy a sóvágóknak szabad költözködési joguk nincs, végül a huszti plébános és a vámszedő házát a sóvágók vonatkozásában menedékjoggal ruházta fel. ${ }^{287}$

${ }^{283}$ A 15-16. századból pontos árszabások ismertek a celeristák fizetségéről. 1471-ben például Szolnokig 10000 darab hajósó eljuttatásának fizetsége 46 forint és 200 sókocka volt. Draskóczy 2005. 99. A tordaiak a 16. század közepén egy tömény Szegedig szállításáért 42 forint járt. Stb. Oborni 2002. 90.

${ }^{284}$ Draskóczy 2005. 92-93. Ugyanezt remekül igazolja a debreceni sókamara 1434. évi elszámolása, ami alapján a sószállítók többsége falusi lakos volt. Jelzete DL 55061. Közli: Draskóczy 2011. 163-169.

${ }^{285}$ Iványi 1911. 20; Draskóczy 2005. 93-94; Glück 2013. 122-126.

${ }^{286}$ DF 212979.

${ }^{287}$ Általánosságban lásd a témára Iványi 1911; Kovássy 1986; Kerekes 1988. 
A másik ilyen rendelkezés, az Ulászló király által kibocsátott 1498. április 28-i statútum. Kiadásának apropója a bányászok 1492. évi bérlázadása volt, amely szükségessé tette a sóvágók helyzetének újrarendezését ${ }^{288} \mathrm{~A}$ rendelkezés legfontosabb pontjai nagy vonalakban a következők voltak: a sóvágók fizetését megemelték, innentől 100 só után 20 dénárt kaptak, ruházatukra pedig további évi 100 sót. Emellett mentesültek az adók alól, új akna nyitásáért bányaölenként 1 forintot, új tárnákban talált sóért 1000 sót kaptak, a váratlan túlmunkáért pedig külön fizetség járt. A koronavárosok tanácsába innentől a bíró által kijelölt esküdteket küldhettek, illetve saját bírót is választhattak. Választását az ispán és az officiális hagyta jóvá. Huszt, Técső és Sziget városa (amelyek a sóvágók lakóhelyei voltak) a sátoros ünnepeken mindezek mellett meg is vendégelte a sóvágókat. ${ }^{289}$

\section{A sójáradék mint az uralkodói kegy gyakorlásának eszköze}

A sóbányászatból szinte mindenki profitált a környéken. Előnyös volt például a helyi és távolabbi egyházi intézményekre nézve is, ugyanis ezek olyan állandó sójáradékokhoz juthattak hozzá, amelyekhez máshol nem lett volna lehetséges. Így 1439. április 22-én Simon huszti, János técsői és Antal szigeti plébánosok panaszára Albert király felszólította Grapiolus máramarosi és sókamaraispánt, hogy rendezze az egyházak felé bizonyos tartozásait. Mint kiderült, az ispán nekik heti 12 dénárnyi udvarpénzzel és az évenként járó egy-egy ruhára (tunica) elegendő szövettel, illetve föveg (caputium) készítésére való két ulna nagyságú szövettel és egy mentével (pellicium) tartozott a sókamarai misékért, amivel azonban adós maradt. Szintén sérelemként adták elő, hogy azt a sót, amelyet szintén a papi teendőkért a sóbányászoktól szoktak kapni eladásra, nagy kárukra az ispán 20 dénárjával szokta megvásárolni. Azaz a sókockákkal az egyház is kereskedett. Azt is megtudjuk, hogy korábban már Erzsébet királyné is parancsot adott a járandóságok kiszolgáltatására, de mivel azt nem teljesítette, a király újfent felszólította az engedelmeskedésre. ${ }^{290}$

1449-ben egy további járandóságról van adatunk. Hunyadi János kormányzó 1449. július 8-i oklevele alapján a huszti Szűz Mária-kápolna 12 forint értékű sót, vagy 12 forintot kapott rendszeresen a sókamarától. A sót Mátyás 1474-ben hasonlóképpen kiadja nekik. ${ }^{291}$

${ }^{288}$ A lázadásról beszámol Horváth János máramarosi főispán 1492. júniusában Bártfa városának írt levele is. DF 215816.

${ }^{289}$ DL 37329. Kiadása Wenzel 1880. 429-432. és Középkori oklevelek 158-162. (91. sz.). A statútum előzményeire és a "tur"-ra lásd Iványi 1911. 98-100.; Bélay 1943. 30-31.

${ }^{290}$ DL 13358. Bélay 1943. 29.

${ }^{291}$ DL 25201. A két oklevél ugyanazon a jelzeten van meg, amely 17. századi másolat formájában maradt fenn. 
1476. június 9-én Beatrix királyné megerősítette és kibővítette Mátyás adományát. Innentől a sókamara már évi 2000 sót utal ki a huszti Szent Erzsébet-egyháznak a plébánosok és vikáriusok ruházatátára. A királynő egyúttal felszólította Paládi Ferenc máramarosi sókamarást, és a kamara minden alkalmazottját, hogy ennek a parancsnak mindenkor tegyenek eleget. 292 Úgy látszik, a 15. század második felében nőtt meg a sókiutalások száma. Beatrix 1487-ben a diósgyőri pálosoknak rendelt ki sót a máramarosi kamarából, és megparancsolta mindenkinek, hogy ne akadályozzák őket annak elszállításában, s vámot se kérjenek tőlük. ${ }^{293}$

Beatrix királyné 1492. március 24-én malomépítési és -működtetési, valamint sóbányászati jogot is osztott Huszton. Az adomány nyertese anynyi sót bányászhatott ki évente, amennyit a sóvágók két forintért szoktak vágni. Maga a tény is lényeges és a fenti sorba illeszthetô. Még fontosabb informácó azonban, hogy az adomány címzettje a nemes huszti Albert litteratus, aki a helyi plébániaegyház Szent Kereszt testvérülete (confraternitas) képviseletében nyerte el az adományt. Ezzel Huszt is felkerül tehát arra a listára, amelyen azok a települések szerepelnek, ahol vallásos testvérületek működtek a középkor folyamán. ${ }^{294}$

Egyre inkább megjelenik egyébként az a fenti tendencia, hogy a kiutalt sót nem a már korábban kibányászott sókészletből szállítják el, hanem az adományosokra bízzák a só kitermelésének terhét. II. Ulászló 1516. február 13-i oklevelében ugyanígy tesz. Ebben engedélyezi, hogy a nyalábi várban épült Nagyboldogasszony-kápolna, a vár alatt álló Péter és Pál apostolok egyházai, illetve a szőllősi Szent Erzsébet ispotály plébánosai a jövőben a máramarosi kamarán belül 27 forint értékú sót vágathassanak, azt elszállíthassák és eladhassák, amiért cserében heti két misét kötelesek mondani a magyar királyok lelki üdvéért. ${ }^{295}$

Kora újkori másolatban maradt meg egy 1515. évi, egyházi sójáradékkal kapcsolatos rendelkezés. II. Ulászló a huszti egyház Szent Katalin oltárának igazgatója, Mátyás mester által előterjesztett kérésre évi 1200

\footnotetext{
${ }^{292}$ DL 17804.

${ }^{293}$ DL 19269. Kiadása: Aragóniai Beatrix 103-104.

${ }^{294}$ Aragóniai Beatrix 233-234.: Az adományosokra: „,fidelis nobis dilecti nobilis Alberti Litterati de Hwzth Maramorusiensis in sua, ac confratrum Sanctae Crucis in ecclesia parochiali de eadem Hwzth" és „pro usu sacerdotis dictae confraternitatis”. Az adomány tárgya: „ut ipse Albertus litteratus una cum aliis confratribus predictis in rivulis et fluminibus iuxta dictum oppidum nostrum Hwzth decurrentibus, intra terminos scilicet eiusdem oppidi... unum molendinum construendi et erigendi potestatis habeant facultatem" és „de quibuscunque fodinis salium nostre reginalis maiestatis Maromarusiensibus maluerint similiter ad eiusdem sacerdotis usum tantum salium incidi facere, quantum incisores salium pro duobus florenis incident, liberam et securam habeant facultatem". stb. A confraternitasokra összefoglalóan: Kubinyi 1999b., Majorossy 2005.

${ }^{295}$ DL 71140, Perényi 385. sz.
} 
kocsisót adományoz az oltárnak, heti két miséért (Szent Katalin és Szent Anna tiszteletére). A javadalmasok a sót eladhatják, de csakis a királyi sókamarák területén kívül. ${ }^{296}$ Világiak is kaptak néha sójáradékot, városok és a nemesség is. Zsigmond 1429-ben megparancsolja, hogy az eperjesi városfalépítés támogatására kiutalt 28400 só után a szállítás során senki se szedjen vámot. ${ }^{297}$ A már említett adat, miszerint a szikszói kamarából 200 forintnyi sót utaltat ki Kinizsi Pál kamaraispán, szintén királyi parancsra történt, aki így akarta adósságát törleszteni. ${ }^{298}$ II. Ulászlótól 1499-ben Dolhai Péter évi 100 forintnyi sót kap életjáradékként. ${ }^{299}$

Úgy látszik, hogy a sókamara kimeríthetetlen kincsesbánya volt a királyi és királynéi kegygyakorláshoz, ilyen, vagy olyan formában, de a környéken élők közül nagyon sokan részesültek az értékes ásványkincsból, amit később pénzzé tehettek. Kaptak a sókockákból a sóvágók, a sóbányák egyéb munkásai, a sókamara különféle alkalmazottai, papok és egyházak, városok és nemesek. A sókamaraispán nagybani sókereskedelme, mint láttuk szintén jellemző volt. Biztos, hogy a belpolitikai helyzet és a termelés pazarló módja mellett ez is az egyik lényeges oka volt annak, hogy a Jagelló korra a királyi sójövedelmek drasztikusan visszaestek mind Máramarosban, mind országos szinten. Persze, egyelőre még bőven volt miből kiutalni ezeket a sókockákat. 1494-ben a máramarosi sótermelés a növekvő pazarlás ellenére is még 526927 darab sókockát tett ki. ${ }^{300}$

${ }^{296}$ MNL-OL E 41 1753. nr. 9. melléklete (Glück László szíves közlése).

${ }^{297}$ DL 43778. A só kiutalására vonatkozó szövegrész: „de salibus fidelium nostrorum civium nostre civitatis de Eperyes, puta duobus tumenis octo milibus et quadringentis, ipsis civibus per nostram maiestatem in camera nostra Maramorosiensi pro muratione ipsius civitatis nostre Eperyes vocate datis et assignatis" stb.

${ }^{298}$ DL 90150, (1472).

${ }^{299}$ DL 86716. Regesztája: Teleki gyömrői 405. sz.

${ }^{300}$ Draskóczy 2014. 64. 


\section{A MÁRAMAROSI MEZŐVÁROSOK JOGI VISZONYAI: ÖNKORMÁNYZAT ÉS OKLEVÉLADÁS}

\section{Az oklevelekben használt terminológia: villa-oppidum - civitas}

Az öt koronaváros a középkor végén - legalábbis jogi értelemben egyértelműen mezőváros volt. Ezt jól mutatja az erre vonatkozó terminológiahasználat is. Habár az 1329. évi kiváltságlevél településein még villaként vannak említve, Técsőt már 1336-ban civitasként aposztrofálja egy oklevél. ${ }^{301}$ 1406-ban az öt várost együttesen oppidumnak mondják, míg Husztot 1408-ban civitas seu oppidumként említik. 1436-ban Técső szerepel oppidumként. ${ }^{302}$ 1456-ban Hosszúmező és Sziget civitasról esik szó, 1457-ben pedig Sziget, Hosszúmező mindketten oppidumok, akárcsak az öt mezőváros együttesen. ${ }^{303} \mathrm{~A} 15$. század második felére a civitas-említések lassan eltünnek és a városokat egyre inkább oppidumnak, sőt, királyi oppidumnak nevezik. ${ }^{304}$ A vegyes oppidum és civitas említés nem kuriózum, gyakran megjelenik azon mezővárosok kapcsán, amelyek már a 14. században is királyi tulajdonnak örvendtek. ${ }^{305}$

\footnotetext{
${ }^{301}$ Már. Dipl. 14.

${ }^{302}$ Már. Dipl. 144.: „opidorum nostrorum regalium Sigeth, Longiprati, Techew, Wischk et Hawsth"; 156.: „in civitate seu oppido nostro Hust vocato"; 303.: "parte oppidi Thechew".

${ }^{303}$ Már. Dipl. 376.: „,iudicis iuratorum, ac universorum civium ac inhabitatorum civitatis nostrae Hozzywmezew"; 395.: "fidelibus nostris iudici iuratis, ceterisque civibus ac toti comunitati opidi nostri Hwzywmezew vocati”; 402-403.: ,,in opido Zygeth in sede nostra iudiciaria" és „et iuratis civibus liberorum oppidorum in dicto Maramarosio existencium" stb.

${ }^{304}$ Már. Dipl. 437.: „oppidi nostri Zygeth” (1461), 533.: „in opido Vysk” (1476), 584.: „in oppido Hwsth" (1487), 605.: circumspecti cives et hospites oppidi Techew" (1494). Stb.

${ }^{305}$ Gulyás 2013. 340-345.
} 
Érdekesebb, hogy a terminológiahasználat alapján sem lehettek városaink teljesen egyenrangúak, pontosabban: nem mindig tartották a másikat annak: Sziget 1457. évi oklevelében a polgárok magukat civitatis Zygeth formában említik, de Hosszúmező már csak az oppidi regalis Hwzwmezw jelzőt érdemli a szemükben. ${ }^{306}$ Tehát magukat magasabb szintűnek, jelentősebbnek tartották, mint a közös privilégiumban szintén szereplő szomszéd várat. Az öt mezővárosra a középkor folyamán használt, terminológiára lásd az 1. függelék részletes táblázatát!

\section{A mezővárosi tanács és az oklevéladás}

A máramarosi városok által elnyert kiváltságok jó alapot szolgáltattak ahhoz, hogy lakóik a középkor folyamán, ha nem is teljes, de viszonylagos függetlenségben élhessenek. Ennek az önállóságnak a legfontosabb intézménye a különféle ügyekben döntést hozó, oklevéladó tevékenységet folytató, hiteles pecsétet használó mezővárosi tanács volt. A magisztrátus tevékenysége során az országos jogot, a kiváltságlevélben szereplő egyes rendelkezéseket, valamint a környékbeli szokásjogot is figyelembe véve járt el a különféle ügyekben. Ilyen szerepük vizsgálatának legfontosabb forrása a bíró és az esküdtek által kiadott, a település hiteles pecsétjével ellátott mezővárosi oklevél volt, amely a legtöbb esetben tartalmazza a tanácstagok nevét is, így a tanács szerkezetének vizsgálatához, továbbá illetékességének és hatáskörének megállapításához egyaránt jól felhasználható.

A középkori mezővárosok oklevéladása - még ha nem is volt tömeges jelenség - mindenképpen szokványos dolognak tekinthető, amely hasonlóan a mezővárosi pecsétek használatához, külön privilégium általi engedélyezést sem igényelt. Azt is fontos azonban megemlíteni, hogy ezek az oklevelek elvileg csak helyi hitelességgel bírtak, azaz idegenek, például nemesek számára bizonyító erejú dokumentumként való elfogadása nem volt kötelező érvényű. Az oklevéladás - hogy milyen ügyekben állítottak ki bizonyságlevelet - egyúttal a magisztrátus hatáskörét is remekül illusztrálja, még ha nem is fedi át teljesen. ${ }^{307}$

A máramarosi mezővárosok oklevelei az országos gyakorlatnak megfelelően csupán helyi hitelességgel rendelkeztek. Ezért, amennyiben például a környékbeli nemesség akart kiállítatni valamilyen ügyben oklevelet, akkor általában az egész északkeleti országrészre, összességében tizenegy

\footnotetext{
${ }^{306}$ DF 247904.

${ }^{307}$ A témára nézve a legfontosabbak Bácskai 1971; Ladányi 1992; Kubinyi 1999a; Gulyás 2008a., Lakatos 2013; 2014.
} 
megyére kiterjedő hatósugarú leleszi konvent írásbeliségének szolgáltatásait vette igénybe. ${ }^{308}$

A vizsgált térségből azonban szerencsére rendelkezünk néhány ilyen, a helyi magisztrátus által kiállított irattal. Eredetiben vagy fényképmásolatban a Magyar Nemzeti Levéltár Országos Levéltárának gyưjteményében található Técső 1456. június 24-i, Sziget 1457. május 25-i, Huszt 1478. július 6-i, 1480. július 25-i, 1504. január 30-i, illetve Hosszúmező 1499. május 7-i oklevele. ${ }^{309}$ Már nincsen meg eredetiben, csupán Mihályi János okmánytára őrizte meg Sziget 1383. október 7-i és 1461. évi okleveleinek szövegét. ${ }^{310}$

Az ötödik koronaváros, Visk nem rendelkezik fennmaradt kiadványnyal a korszakból, de társaihoz képest amúgy is meglehetősen ritkán szerepel a középkor végi forrásokban.

Ha az oklevelek szerkezetét, felépítését, külső és belső jellemzőt nézzük, akkor jól látszik, hogy a máramarosi mezővárosok oklevéladása a 15. század közepére már megszilárdult, ami hosszas fejlődés eredménye lehetett. Eből következik, hogy eredetileg minden bizonnyal több oklevelet foglalhattak írásba, mint ami jelenleg a rendelkezésünkre áll.

Úgy tünik, történetük korai időszakában a koronavárosok olykor még kollektíven is állítottak ki oklevelet a különféle ügyekben. Erre utal mindenesetre, hogy amikor Zsigmond 1406-ban Alsó-Apsa harmadát, valamint Felső- és Közép-Apsát újonnan adományozza az azt korábban is birtokló apsai vlah nemességnek, a birtokosok arra hivatkoznak, hogy korábban is rendelkeztek a birtokjogukra vonatkozó oklevéllel, de a Nagy Lajostól elnyert adománylevél a moldvai betörés alkalmával, amikor háza-

\footnotetext{
${ }^{308}$ Kumorovitz 1928. 5.

${ }^{309}$ DF 247901, DF 247904, DL 70984 (kiadása: Perényi 578. sz.), DF 285466, DL 21247, DF
} 247927. Utóbbi, azaz a hosszúmezei kiadvány helyes dátuma nem május 5., hanem május 7.: „Datis in Hwzywmezew feria tertia proxima post Dominicam vocem Jocunditatis anno Domini 1499." A Magyar Nemzeti Levéltár gyűjteményében található oklevelek mellett egy további oklevél is szóba jöhet, mint a máramarosi városok kiadványa. Sziget mezőváros 1499. május 28-i oklevelének újkori másolata a bukaresti állami levéltárban található (Direcția Arhive Naționale Istorice Centrale, Colecţia achiziții noi DCCXCII/1.). Említi: Magyar Okl. Rom. 122. sz. Egy másik, a szöveg szerint bizonyos „Sziget” város által 1458-ban kibocsátott oklevél (DF 203345) pedig úgy tünik, nem Máramarossziget kiadványa, hanem a dunántúli Sárvár (Sársziget) okleveléről van szó, amit az is bizonyíthat, hogy az ország keleti részén kevésbé megszokott módon polgármester szerepel benne („magister civium iudex et iurati civitatis Zygeth"), illetve hogy a soproni levéltárban maradt fenn. Tévedtem tehát, amikor korábban a máramarosi Sziget oklevelének tulajdonítottam. Gulyás 2013. 335. (74. jegyzet). Az információért Lakatos Bálintnak tartozom köszönettel.

${ }^{310}$ Már. Dipl. 80, 434-435. Az okmánytár szerkesztésekor az 1461. évi oklevél már súlyosan rongálódott volt, bal fele gyakorlatilag hiányzott. Mihályi János megjegyezte, hogy azért is vette fel a csonka oklevéldarabot az okmánytárába, mert talán még előkerülhet a hiányzó része. Nem lett igaza, hiszen ennek a félnek is nyoma veszett azóta, legalábbis nem sikerült a nyomára bukkannom. 
ik leégtek, megsemmisült. Ezt pedig az öt királyi város - azóta már elveszett - oklevelével igazolták. ${ }^{311}$

Az önálló oklevéladás mezővárosainkban nem egy időben alakult ki. A legelső, napjainkig fennmaradt okmányt a szigetiek adták ki 1383-ban, de ebben utalás történik egy még korábbi kiadványukra, amelyet a hoszszúmezeiek kérésére foglaltak írásba a helyi hospesek és a szaploncai nemesek közötti birtokhatár ügyében. Azaz, a hosszúmezeieknél ekkor még nem vált rutinszerú gyakorlattá a hivatali írásbeliség, ebben Sziget járhatott az élen, s ezért hozzájuk fordultak a határleírás oklevélbe foglalásáért a közös privilégium alá tartozó szomszédok is. Persze az sem kizárt, hogy azért volt szükség „idegen” oklevéladóra, mert a hosszúmezeiek érintettek voltak az ügyben. ${ }^{312}$

\section{A tanács szerkezete}

A máramarosi városok bírái már a 14. századtól rendszeresen szerepelnek a forrásokban. Igaz, a tanács szerkezetére vonatkozó adatunk eleinte nem nagyon van, általában csak a bíró nevét és a tisztsége megnevezését ismerjük. Mint a kiváltságlevéllel és megújításaival kapcsolatosan már láthattuk, a tanács élén álló bírák a 14. században még villicusként, azaz „falunagyként" szerepelnek a forrásokban. Az elnevezés nem számít különlegesnek: a 14. század folyamán a különféle városias települések megnevezése még általában ingadozott a forrásokban (villa - libera villa - oppidum - civitas), ahogy a települések élén álló tisztviselő, a bíró megnevezése is (villicus - maior ville - iudex). Azaz a máramarosi terminológiahasználat is az országos fejlődést mutatja. ${ }^{313}$

\footnotetext{
${ }^{311}$ Már. Dipl. 144. „Super quibus quidem expositione et relatione combustionis litterarum privilegialium predictarum modo premisso et nominibus quibus supra coram nostra celsitudine factis ut prefertur ad ostendendum veritatem premissorum in vim probationis legittime litteras efficaces opidorum nostrorum regalium Sigeth, Longiprati, Techew, Wischk et Hawsth commetaneorum suorum produxerunt et exhibuerunt".

${ }^{312}$ Már. Dipl. 80. (1383. október 7.). A szigeti polgárok - ilyenre sem nagyon van példa ismereteim szerint a középkori mezővárosi oklevéladásban! - újabb oklevelükkel érvénytelenítik korábbi kiadványukat: „,quod pridem venientes ad nostram presenciam iudex ac universi cives et hospites de Longopratho, et a nobis postulantes literas nostras super hoc, quod iuxta constitutam morem deberent procedere et inquirere methas ipsorum usuales rectas. Igitur nos communi consilio pertractavimus conscienciose ac seriose, mediante fide nostra eisdem concessimus literas nostras", mivel azonban ,iuxta nostras literas super methas eorum digne non sunt processi, igitur cognita nequicia ipsorum eisdem nobilibus... concessimus literas nostras patentes, id quod ipsi homines prephati de Longopratho cum literis nostris posterum procedere non valeant, ante eisdem a nobis concessis, et minime sit valiturus (!) littera ante lata."
}

${ }^{313}$ A kérdésre összefoglalóan lásd Ladányi 1980. és Ladányi 1992. 
Ez a helyzet valamikor a 15. század elején változott csak meg, amikor az oklevelekben egyre következetesebben három kategória kezdett megjelenni. A szabad királyi-, királyi szabad- és bányavárosokat, valamint a püspöki székhelyeket így egyre inkább civitasnak nevezték, a mezővárosokat oppidumnak, míg a falutelepülésekre a possessio és villa terminológiát kezdték el alkalmazni. A civitasokban szinte mindig, ${ }^{314}$ a mezővárosokban pedig általában iudex állt a közösség élén, míg a falvakban a legtöbbször csak villicus. De kivételek természetesen ekkor is előfordultak mindkét terminológiakategóriában, főként a mezővárosok megnevezése ingadozott a forrásokban, a megnevező személyétől sem éppen függetlenül.

A terminológiahasználatban kifejezetten érdekes jelenség figyelhető meg a koronavárosokkal kapcsolatosan. A mezővárosok 1329. évi privilégiumának Zsigmond idején történő átírásakor az átírást 1404-ben és 1435ben kérvényező mezővárosi küldöttség tagjai a szöveg szerint villicusok voltak, településeik pedig az átírt privilégium rendelkezéseiben villa néven kerültek lejegyzésre. ${ }^{315}$ Főleg az 1435. évi adat igazán gyanús, hiszen ekkor már az országos hivatali írásbeliségben nem így neveznek egy jelentôs királyi mezőváros élén álló bírót. Ahogy láthattuk, a privilégium és későbbi átírásai is csak újkori másolatokban maradtak fenn, ezért talán arra is következtethetnénk, hogy a szöveget másoló, korábbi okleveleket átíró írnok módosította az eredeti iudexet és cserélte le a villicusra valamiért.

Sokkal inkább arról lehet azonban szó, hogy a megerősítés során az eredeti, villicus választását engedélyező kiváltságlevél és a 15. században a bíróra használt, a korban már mindennapos iudex kifejezések között feszülő ellentmondást a megerősítések írásba foglalói érzékelték. Ezt a pontosítást, a félreértések elkerülése érdekében pedig úgy oldották meg, hogy az eredeti oklevélben szereplő archaikusabb és hasonló szintü településekre már nem nagyon használt, de számukra még így is érthető és egyértelmü villicust érintetlenül hagyták, és azt alkalmazták az oklevelet átíró keretszövegben is.

Magára a tanács szerkezetére nézve első adataink a 14. századból származnak. 1373-ban, Hosszúmező és Szaplonca határjárásában Hosszúmező bíráját és esküdtjeit említik. ${ }^{316}$ Tíz évvel később, Sziget város oklevelében

\footnotetext{
${ }^{314}$ Vannak városaink, illetve német lakosságú mezővárosaink is, amelyek polgármesterrel rendelkeznek!

315. 1404. június 3-án „fideles nostri viri providi Ladislaus de Hust, Georgius de Visk, Franciscus de Techö, --- de Szigeth villici nostri" jártak el a megerősítés érdekében. Az 1435. március 12-i királyi megerősítés a személyesen megjelenő „Joannes dictus Kethel de Visk et Benedictus magnus de Hust villici" kérésére történt. DL 2539.

${ }^{316}$ Már. Dipl. 69. „iudex iurati ac universi hospites in Huzyumezeu”.
} 
a szigeti bíró és esküdtek, illetve a hosszúmezei bíró szerepelnek. ${ }^{317}$ A 15 . század közepétől az említések állandósulnak. 1435-ben a técsői, 1456-ban, 1457-ben és 1458-ban a hosszúmezei, 1459-ben és 1461-ben a szigeti, 1504ben a huszti és szigeti, 1517-ben a huszti bírót és esküdteket említik a források. ${ }^{318}$

A tanács részletesebb felépítésére nézve elsősorban a helyi kiadású, azaz a mezővárosi oklevelek nyújtanak tájékoztatást. Sziget város 1383. évi oklevelében, mint az láthattuk, az országosan elterjedt terminológiának megfelelően a bíró, az esküdtek, a polgárok és hospesek szerepelnek (iudex, iurati ceterique cives et hospites de Zygeth). ${ }^{319}$ 1457. május 25-ére keltezett oklevelükben azonban már ennél sokkal hierarchizáltabb tanácsszerkezettel állunk szemben. Az oklevél kibocsátói ugyanis Sziget királyi város név szerint meg nem nevezett bírája, esküdtjei és a tizenkét „vén”. ${ }^{320} \mathrm{~A}$ mezőváros harmadik, 1461. évi sérült okleveléből viszont oly sok szövegrész hiányzik, hogy nincs benne semmilyen érdemi adat a tanácsszerkezetre vonatkozólag. ${ }^{321}$

Técső 1456. június 24-i oklevelében négy bíró és tizenkét választott vén alkotja a tanácsot. ${ }^{322}$ Huszt oklevéladó-gyakorlatára nézve 1478-ből származik az első adatunk. Ez év július 6-án kibocsátott oklevelük kiadói a bíró, az esküdtek és a polgárok voltak. ${ }^{323} 1480$. július 25-én kiállított iratukban a bíró, az esküdt polgárok és a huszonnégy vén alkotja a magisztrá-

\footnotetext{
${ }^{317}$ Már. Dipl. 80. „Nos Nicolaus Bogaz iudex, iurati ceterique cives et hospites de Zygeth”, illetve "venientes nostram ad presentiam iudex ac universi cives et hospites de Longopratho".

${ }^{318}$ Már. Dipl. 300..: „iudex et iurati nec non ceteri cives oppidi nostri Thechew vocati”; Már. Dipl. 222. 376-377.: „Dicitur nobis in personis iudicis iuratorum, ac universorum civium ac inhabitatorum civitatis nostrae Hozzywmezew”, Már. Dipl. 395.: „fidelibus nostris iudici iuratis ceterisque civibus ac toti comunitati opidi nostri Hwzywmezew vocati" és Már. Dipl. 406.: "contra iudicem, iuratos ceterosque cives de Hosswmezew”; Már. Dipl. 429.: „Simon iudex" (egy helyi birtokügy tanujaként) és Már. Dipl. 437.: „Stephani peleficis iudicis dicti oppidi nostri Zygeth"; az említett 1504. évi kiváltságlevélben: „fideles nostri circumspecti Thomas Emerici iudex oppidi in Huszt, necnon Laurentius Szász iudex oppidi in Szigeth in suis, omniumque iudicum et iuratorum civium communitatumque quinque oppidorum nostrorum Maromorosiensium nominibus" (DL 22477); DL 84631.

${ }^{319}$ Már. Dipl. 80. Budán talán társadalmi okok rejtőztek a cives és a hospites kifejezések között. Előbbi csoport a városi vezetőréteg tagjait foglalta csak magában. Vö. Kubinyi 1971b. 214-215.

${ }^{320}$ DF 247904: „iudex iuratique cives ac duodecim senes civitatis regalis Zygeth".

${ }^{321}$ Már. Dipl. 434-435.

322 "Nos Paulus Neste, Clemens Honnos, Mathyas Barkazy, Thomas Zay iudices ac duodecim electi seniores ceterique cives et universi hospites de Theczw". DF 247901.

${ }^{323}$ "Nos Michael Zabo iudex de Hwzth iuratique et universi cives de eadem Hwzth".DL 70984 .
} 
tust. ${ }^{324}$ 1504. évi január 30-ára datált, homagium átvételéről kiállított nyugtájukban a bíró, az esküdtek és a huszti polgárok szerepelnek. ${ }^{325}$

Hosszúmező egyetlen fennmaradt oklevele a 15. század végén keletkezett. Valószínúleg amúgy is az utolsók között kezdhette meg a hivatali írásbeliséget. 1499. május 7-re datált oklevele szerint kiadói a bíró, az esküdtek és a mezőváros lakói. ${ }^{326}$

Láthatólag a máramarosi mezővárosokban más korabeli oppidumokhoz hasonlóan fejlettségtől függően eltérő időben jelent meg az oklevéladás. A tanácsszerkezet felépítésében is vannak bizonyos szerkezeti eltérések, és azt sem szabad elfelejteni, hogy a tanács létszáma a település nagyságának függvénye is volt, hiszen kevesebb lakos esetén az elvégzendő feladatok száma is kisebb.

Egy-egy település magisztrátusa egyébként soha nem volt állandó, hanem az idő haladtával szinte mindenhol kimutathatók változások a tanácstagok számát és megnevezését illetően, azaz ebben a kérdésben is az országos viszonyoknak megfelelő helyzettel állunk szemben. ${ }^{327}$ Van azonban egy olyan jellegzetesség, amely többé-kevésbé egységes máramarosi tanácsberendezkedésre utal, és nem túl gyakori országos szinten sem: három mezővárosban is vannak „választott öregek”. Az electi seniores esetében talán a szükebb tanács mellett álló „külső tanács” intézményéről lehet szó, amely civitasok esetében szokványos volt, de olykor mezővárosokban is megjelent, mégpedig egyértelmüen a városok kisugárzásának, jogi mintájának köszönhetően. ${ }^{328}$ Szigeten, Técsőn és Huszton a bíró és a meghatározhatatlan számú esküdtek mellett tehát tizenkét vagy huszonnégy választott „öreg” állt, akiknek gyakorlati feladatáról sajnos nem tudunk semmi konkrétumot. ${ }^{329}$

Egy fontos következtetést azért mégis levonhatunk. Ez a berendezkedés nem belső fejlődés eredménye volt, hanem egyértelműen külső minta átvétele lehetett. Eddig is szóltunk már arról, hogy a máramarosi koronavárosok között nem csak a példaképpen szolgáló privilégiumlevél, de a kimutatható szőllősi fellebviteli fórum miatt is aránylag szoros kapcsolat állt fenn. Ezt megerősíti a tanács berendezkedése is: úgy látszik, az electi se-

\footnotetext{
${ }^{324}$ „Nos Urbanus iudex ac iurati cives necnon viginti quattuor senes de Hwzth”. DF 285466.

${ }^{325}$ "Emericus Thomas iudex ceterique iurati et universi cives de Hwzth". DL 21247.

${ }^{326}$ "Iudex iuratique ac universi hospites et inhabitatores oppidi Hwzywmezew". DF 247927.

${ }^{327}$ Gulyás 2008a. 82-86.

${ }^{328}$ Több ilyen példánk van a régióból, ezekből lássunk néhányat! Kurima, 1522: „iudex et iurati ac consules oppidi Curima” (DF 218056); Sztropkó, 1489: „iudex iuratique consules oppidi Stropko" (DF 215468); Miskolc,1461: „iurati cives et consules opidi Miskolcz” (DL 15547). Liszkán húsz „választott polgár” alkotta ezt a testületet. Gulyás 2008a. 86.

${ }^{329}$ Említi a jelenséget Lakatos 2014. 522.
} 
niores intézményét a mezővárosok Szőllősről kölcsönözhették. Szőllős mezőváros egyetlen fennmaradt, 1515 újévének napján kiállított szőlőadásvételében ugyanis két bíró, tizenkét esküdt és huszonnégy vén szerepel, mint az oklevél kibocsátója. ${ }^{330}$

Az átvételt az is bizonyíthatja, hogy a vének száma a legközelebb fekvő és Szőlőssel ezért legszorosabb kapcsolatot ápoló Huszt esetében volt pontosan ugyanennyi, míg a távolabbi koronavárosokban már csak módosult formában alakult ki ez a jelenség.

A tanács választásának módjáról és időpontjáról - mint a legtöbb esetben - semmi adatunk nincsen, ezt egyébként a legtöbbször a privilégium sem szabályozza, ehelyett a helyi szokásjogra bízza. ${ }^{331}$ Az országos helyzethez hasonlóan a választásokon itt is a települések szükebb vezetőrétege dominálhatott. 1498-ban a választás mindenesetre egy pontban mindenképpen módosult. Innentől kezdve ugyanis az Ulászló-féle rendelkezés értelmében a sóvágók is képviseletet kaptak az esküdtek között és a polgár és sóvágó között keletkező ügyekben csak vele és a sóvágók bírájával közösen lehetett ítélniük. ${ }^{332}$

\section{A magisztrátus illetékessége és feladatkörei}

A mezővárosi magisztrátus feladatkörei a falvakéhoz képest - de természetesen fejlettségüktől és jogi helyzetüktől függően - meglehetősen sokrétüek voltak. Általában a magisztrátusra hárult az adóterhek felosztása, ők végezték a vásár felügyeletét, valamint hitelesítették az adásvételi szerződéseket és végrendeleteket. Mindezek mellett képviselték a közösség különféle magánjogi igényeit az extraneusokkal szembeni ügyekben. ${ }^{333}$

Ami a legfontosabb volt, az a bíráskodási szerepük: a magisztrátus a településen élők felett a kiváltságaitól függő mértékü joghatóságot gyakorolt. Ezt néhány dolog azért korlátozhatta. Az egyik az volt, hogy a mezőváros néhány kivételtől eltekintve csak a kisebb - azaz nem főbenjáró - ügyekben ítélkezhetett, kivéve, ha kiváltságlevele lehetővé tette ennek ellenkezőjét.

\footnotetext{
330 "Nos Andreas Kochys ac Urbanus Kowach iudices oppidi Zewlews duodecimque iurati et viginti quatuor senes de eadem". DL 84623.

${ }^{331}$ Fügedi 1981. 281-285.

${ }^{332}$ Iványi 1911. 101-103. Már. Dipl. 617.: „ordinavimus etiam, quod singulis annis ex incisoribus salium aliqui probi viri per iudices oppidorum Hwzth, Theczew et Zigeth pro iuratis civibus eligantur, quibus presentibus iudices ipsi, vel aliquis eorum ac pariter iudices incisorum ipsorum, causas et negotia inter oppidanos et incisores ipsos emergentes et suborta adiudicent et concludant eo potissimum respectu, ne iudices oppidanorum sine presentia iudicum et iuratorum incisorum ipsorum aliquem vel aliquos ex incisoribus possint vel valeant in iudicio in suo arbitrio aggravare."

${ }^{333}$ A mezővárosi tanács széles hatáskörére: Bácskai 1971.
} 
Ha officiális volt jelen a településen, vagy a földesúri fennhatóság valami oknál fogva (például, ha rezidenciaként is funkcionált az oppidum) az átlagosnál szorosabb volt, akkor jogkörük általában még ezt a szintet sem érte el, bíráskodni sokszor csak a földesúrral vagy annak képviselőjével állt módukban. Az is hátrány volt, hogy bírói joghatóságukat az idegenek, városi polgárok, egyháziak és nemesek nem voltak kötelesek elfogadni. ${ }^{334}$ Természetesen a középkor végén - ahogy azt fentebb már láthattuk - a nyilvános gonosztevők felett joghatóságot gyakorolhattak. ${ }^{335}$

A tanács kezelte emellett a mezőváros pecsétjét, amely a település viszonylagos függetlenségének bizonyítéka, a mezővárosi identitás kézzelfogható jelképe is volt egyúttal. A máramarosi mezővárosi kiadványok alapján, nyilván itt is az országosan megfigyelhető spontán módon kialakulva, településeink használtak pecsétet, és többször hivatkoznak is erre okleveleik corroboratiójában. ${ }^{336}$ Sokatmondó azonban, hogy pecsétjüket egyszer sem nevezik authenticusnak.

A máramarosi hospesek az 1329. évi kiváltságlevélben foglaltaknak megfelelően korlátozott joghatóságot kaptak, amely csak a 16. század elején bővült érdemben, amikor a már ismertetett módon a polgárok megszerezték a pallosjogot. A középkor végén illetékességük egy szempontból további csorbát szenvedett. Bírói joghatóságuk az 1498. évi statútumig minden bizonnyal a bányászokra is kiterjedt, de ez a rendelkezés ezt a kedvező jogi helyzetet megszüntette, hiszen a sóvágók innentől már saját bírót választhattak maguknak, s ezután a polgárokkal szembeni ügyekben a két bíró csak együtt ítélhetett. Azaz a sóvágók jogilag külön közösséget alkottak, mint a többi városlakó. ${ }^{337}$ Jól mutatja illetékességüket, joghatóságuk határait az az eset, amikor 1514. április 8-án Laskody János máramarosi főkapitány felszólította Técső és Hosszúmező városokat, hogy Dolhai Péter feleségét ne zaklassák, hiszen ha büncselekményt követett el, akkor megbüntetése a főkapitány feladata. ${ }^{338}$

${ }^{334}$ Bácskai 1971. 11; Fügedi 1981. 284-285. A hegyaljai mezővárosok önkormányzatának feladatkörei remekül példázhatják ezt a sokrétű hivatali tevékenységet. Gulyás 2008a. 131163.

${ }^{335} \mathrm{Az}$ országos jogelvet, miszerint a malefactorokat bárki letartóztathatta, a jobbágyság is széles körben ismerhette és alkalmazhatta országszerte. Sztropkó például ennek megfelelően 1521-ben egy ilyen személyt megbilincselt és fogságba vetett a településen. DF 271691.

${ }^{336}$ Técső (1456): „appensione nostri sigilli consignatas”. DF 247901; Sziget (1461): „literas nostras sigillo dicte nostre civitatis roboratas". Már. Dipl. 435; Hosszúmező (1499): „presentes litteras sigillo nostri oppidi consignatas". DF 247927.

${ }^{337}$ Iványi 1911. 16-17. A sóvágók jogi különállását mutatja, hogy közösségüket az 1498. évi királyi statútum is jogi személyiséggel rendelkező universitasként aposztrofálta. Már. Dipl. 617.: ",universitati incisorum in Zygeth commorantium”.

${ }^{338}$ DL 62999. 
A koronavárosok magisztrátusának hatásköréről csak szórványinformációkkal rendelkezünk. Először is, nyilvánvaló, hogy különféle perekben döntöttek, vagy segítették elő a döntést. Sziget tanácsa előtt 1457-ben határper folyt, mégpedig Hosszúmező és a szaploncai, illetve szarvaszói nemesek között egy határjel miatt, amelyben végül megegyezés született. Itt a szigetiek fogott bírákként szerepeltek. ${ }^{339}$ Huszt mezőváros 1478-ban hagyatéki ügyben, fogott bírák segítségével meghozott döntésről állított ki oklevelet. ${ }^{340} 1480$-ban hasonló történik, ekkor egy malomrész miatti perben születik a szigeti magisztrátus előtt megegyezés. ${ }^{341} \mathrm{~A}$ tanács adhatott ki emellett ügyvédvalló-oklevelet is, mint azt Hosszúmező magisztrátusa 1499-ben meg is tette. ${ }^{342}$

Técső 1456-ban a hosszúmezeiek szántójának és kaszálójának elfoglalása miatti ügyben állít ki bizonyságlevelet, amelyet a szaploncai és szarvaszói nemesek lekaszáltak, illetve megszállva tartottak. ${ }^{343}$ Huszt mezőváros 1504-ben oklevelet, pontosabban nyugtát adott ki a Thoth István által a fia megyilkolása miatt fizetett vérdíj átvételéről. ${ }^{344}$ Sziget 1461-ben Pontz György szigeti polgár és a környékbeli nemesek közötti egyezségről készített írásos dokumentumot. ${ }^{345}$

Mint láthattuk, városaink közül a fejlettebbek a kevésbé jelentős szomszédaik jogi életében is szerepet játszottak olykor: Sziget és Técső a 15. század közepén a kisebb jelentőségű Hosszúmező ügyében járt el. A koronavárosok között a közös múltnak és a kollektív kiváltságlevélnek köszönhetően szoros kapocs alakult tehát ki.

Sajnos a magisztrátus további középkori feladatkörei konkrét említések hiányában nagyrészt homályban maradnak. Egyetlen ehhez kapcsolódó adatot ismerünk csupán: a tanácsnak Huszton egyértelmúen a feladatai közé tartozott a kocsmáltatás ellenőrzése is. II. Lajos 1517. évi oklevele részletesen beszámol arról, hogyan vizsgálta meg a bíró az eladandó bor minőségét: a bortermelő a megjelölt napon kitette házára a cégért és a bírónak borából kóstolót küldött. A város vezetője végül a nedű minősége szerint állapította meg az árat, amennyiért a bort árusítani lehetett a településen. ${ }^{346}$

\footnotetext{
${ }^{339}$ DF 247904.

${ }^{340}$ DL 70984. Kiadása: Perényi 578. sz.

${ }^{341}$ DF 285466.

${ }^{342}$ DF 247927.

${ }^{343}$ DF 247901

${ }^{344}$ DL 21247.

${ }^{345}$ Már. Dipl. 434-435.

${ }^{346}$ DL 84631. „quod quamvis oppidum nostrum Hwzth, et per consequens inhabitatores eiusdem in educillandis et propinandis vinis talem habuerint ab antiquo consuetudinem, habeantque etiam impresentiarum, ut quicumque ex ipsis vinum iniciare et educillare voluerit antequam iniciet et signum exponat iudici significet et solitam mensuram de huiusmodi
} 
Úgy tűnik, ez a szokás a máramarosi mezővárosokban máshol is megjelent. A 16. századi, de Mohács után keletkezett források általában jól használhatók a középkor végi helyzet vizsgálatához, ez pedig még hatványozottabban igaz a városi és mezővárosi statútumokra, hiszen a szokásjog fejlődése lassú és kontinuus módon történik, abban nincsenek éles „hajtűkanyarok".

Szerencsés módon a 16. század közepi koronavárosainkból is rendelkezünk ilyen joggyüjteményekkel, amelyeket ezért mindenképpen érdemes összevetni a középkori helyzettel. ${ }^{347}$ Figyelemre méltó, hogy Máramarossziget 1548. évi statútuma a középkor végi huszti rendelkezéshez hasonló módon szabályozta a bormérést a településen. Itt is a bíró játszotta a minőségi kontroll szerepét, távollétében a minőség-ellenőrzés során még az esküdtek sem pótolhatták a személyét. Az eladni szándékozónak „látó poharat" kellett a város vezetője számára adniuk, és 3 pénzt kellett letenni a vizsgálatért, amit a helyi Szent Imre-plébánia kapott meg. Aki e nélkül az engedély nélkül árulta a borát, azt eltiltották a kereskedéstől. ${ }^{348}$

Visken ugyanez a helyzet: senkinek nem volt szabad a bíró számára küldött „,átó bor" nélkül az italt árulni. A bíró itt egy iccét, a két esküdt pedig fél-fél iccét kapott fizetség gyanánt. Ha valaki ellenőrzés nélkül kezdett a bor árulásához, a tanács lefoglalhatta azt. ${ }^{349}$

A bormérés joga a fentiek szerint a középkor folyamán egyértelmüen megillette a máramarosi polgárságot. Ez a későbbiekben is így maradt, egyetlen kivétellel. Huszton 1629-ben a 150 forintnyi cenzus elengedéséért cserében Bethlen István megszüntette a szabad bormérés lehetőségét, és ezután egész évben csak az uraság árulhatta a borát. ${ }^{350}$

vino educillando ad gustandum illi porrigat et cum scitu annuentiaque atque permissione iudicis illud iniciet et eo pretio quo ille idem limitaverit educillare debeat." Az oklevél arról is beszámol, hogy az egyik legismertebb huszti polgár, Barilovics Miklós házát a király az apja iránt tanúsított hüségéért megnemesítette, s egyúttal a bor említett bemutatási kötelezettsége alól is felmentette.

${ }^{347}$ Fennmaradt Sziget 1548. évi (de 1569-es átírásból ismert), 1596. évi és 1603. évi, valamint Visk valamivel későbbi, 1641. évi statútuma. MTHJ III. 551-557., III. 573-575., III. 576-577., III. 610-615. Az 1548. évi szigeti statútum bevezetô része is azt sugallja, hogy itt egy hoszszabb időre visszamenő joggyakorlat rögzítéséről van szó, már ha nem puszta frazeológia az „„ösök" emlegetése a statútum szövegében. Ebben ugyanis a törvényeket úgy említik meg, mint amelyekkel „,az ő atyjok és ősök éltenek, megtartottak és ez mostaniakra maradt.” MTHJ III. 551. Két évtizeddel Mohács után még bizonyosan nem történhettek jelentős változások a középkor végi szokásjogban, tehát ezek a források felhasználhatónak tünnek a középkori, de még inkább a középkor végi helyzet vizsgálatához.

${ }_{348}$ MTHJ III. 552-553.

${ }^{349}$ MTHJ III. 612-613.

${ }^{350}$ Glück 2013. 362. 


\section{A kora újkori statútumok rendelkezései és a középkori önkormányzat}

A fenti, egymással és az 1517. évi példánkkal is párhuzamba állítható adat alapján is kijelenthető, hogy egyrészt, ezeknek a 16-17. századi máramarosi rendelkezéseknek bizonyos részei már a középkor végén (esetleg még korábban) is érvényben lehettek már a településeken. Másrészt pedig, hogy a koronavárosok joghasználatában a közös privilégium miatt is komoly párhuzamok létezhettek. Felmerül a kérdés, hogy vajon melyek lehettek azok a rendelkezések, amelyekre ez a kijelentés leginkább vonatkoztatható?

Ebből a szempontból különösen gyanús a szigeti statútum azon pontja, amely a bíróválasztásra utal. Szigeten a bíró, de az iskolamester is Szent György napján került megválasztásra, és előbbi mellé még négy esküdt bírót állítottak. Ebből kettőt a nép, kettőt pedig a 24-es tanács és a bíró választott meg, akik a plébánosnak tettek esküt. A bíró köteles volt mindenkinek igazságot szolgáltatni. ${ }^{351}$

A bíróválasztás napja, Szent György (április 24.) Szigeten minden bizonnyal középkori eredetű volt, hiszen köztudottan ez volt a leggyakoribb időpontja a tisztújításnak a királyi városokban. Könnyen feltehető, hogy a kollektív privilégiumnak köszönhetően a többi mezővárosunkban is ekkor történt a tisztújítás. A Viskről fennmaradt 1641. évi statútumunk segíthetne ugyan a kérdés eldöntésében, ám ez beszél ugyan néhány szóban a bíróválasztásról, de sem a tanács összetételéről, sem a napjáról nem számol be. Csupán annyit tudunk meg belőle, hogy a város választja a főbírót, majd az esküdteket a frissiben megválasztott iudex jelöli ki. ${ }^{352}$

A tanácstagok számával kapcsolatosan még nehezebb ilyen megállapításokat tenni. Mint azt korábban is láthattuk, a tanács felépítését csupán egyetlen oklevél közli, ez pedig Técső kiadványa, ahol négy bíró mellett tizenkét vén alkotja a magisztrátust. Ez a "négy bíró" talán lehet valamilyen összefüggésben a Szigeten 1548-ban látott négy esküdttel, de sajnos nem lehet biztos kijelentést tenni a kérdésben.

$\mathrm{Az}$ is érdekes megjegyzés a statútumban, miszerint a városi törvényszék a hét negyedik napján, azaz szerdán ült össze Szigeten. ${ }^{353}$ Logikusan hangzik, hogy az okleveleket is a törvényszék napján, azaz ugyanígy szerdán állíthatták ki. Sziget mezővárosnak, ahogyan azt már közöltük, három középkori kiadványa maradt korunkra. Ebből az erősen rongálódott, később pedig elveszett 1461. évi kiadvány pontos datálása sajnos már nem

\footnotetext{
${ }^{351}$ MTHJ III. 551.

${ }^{352}$ MTHJ III. 610-611.

${ }^{353}$ MTHJ III. 552.
} 
lehetséges. ${ }^{354}$ A másik két oklevél, azaz az 1383. október 7-i és 1457. május 25-i kiadvány kibocsátásának napja azonban éppen szerdára esett! ${ }^{355}$ Úgy gondoljuk ez egyértelmú adat arra nézve, hogy már a középkorban is feltehetően szerdán volt a törvénynap és az ezzel összefüggésben végzett oklevél-kiállítás Szigeten.

Ha gyorsan átfutjuk a többi oklevelünket is, akkor megállapítható, hogy e logika alapján Huszton a törvénynap talán kedden került megrendezésre. A három fennmaradt oklevelük közül ugyanis kettőt ezen a napon bocsátottak ki (1480. július 25. és 1504. január 30.), míg a harmadik, 1478. július 6-i kiadvány datálása hétfőre esett. ${ }^{356}$ Talán összefüggésben állt ezzel a jellegzetességgel az is, hogy Hosszúmezőn szintén kedden kelteztek egy alkalommal oklevelet (1499. május 7.). ${ }^{357}$ Az utolsó, técsői oklevél (1456. június 24.) viszont csütörtöki napon került kibocsátásra. ${ }^{358}$

Az utolsó olyan pontja a kora újkori statutumoknak, amelyben egy középkori szabály köszön vissza egyértelműen, a sóbányászokkal kapcsolatos megjegyzés volt. Mint azt korábban említettük, a sóbányászok az 1498. évi statútum rendelkezéseinek megfelelően saját bírót választhattak maguknak. Az 1548. évi szigeti cikkelyek tesznek is egy fontos utalást a szigeti bíró és a sóvágók bírója közötti viszonyra: egyrészt, a sóvágók vétkeiért a saját bírájuk kezességet vállalhatott a várossal szemben (ellenkező esetben ki kell adniuk a vétkest a városbírónak), másrészt pedig, hogy a sóvágók a kamaraispán előtt perelhetnek ugyan, azonban ha nem sikerül azon a fórumon döntést hozniuk, akkor a szigeti főbíró szolgált fellebbviteli fórumként. ${ }^{359}$ Bizonyos esetekben tehát mégis csak érvényesült a város joghatósága a sóbányászok felett is.

A felsorolt pontokon kívül a kora újkori statútumok rendelkeznek még Szigeten a vérdíj kérdéséről és a szitkozódás tilalmáról, a törvényszéki ülés szabályairól, a hamis mértékek tiltásáról, a vásár rendjéről, a tartozások behajtásának módjáról, a kovácsok és szekeresek munkadíjáról, a tizedek létrehozásáról és a kinevezett tizedesekről, Visken pedig az adószedés rendjéről, a város kiadásainak feljegyzéséről, ami szintén a bíró feladata volt. . $^{360}$ Nyilvánvaló, hogy ezek a szabályozások részben már Mohács előtt is használatban lehettek, de jól mutatják a mezővárosi tanács komplex feladatköreit is.

\footnotetext{
${ }^{354}$ Már. Dipl. 435.

${ }^{355}$ Már. Dipl. 80., DF 247904. A datálás ellenőrzéséhez lásd Szentpétery 1985.

${ }^{356}$ DF 285466, DL 21247, DL 70984.

${ }^{357}$ DF 247925.

${ }^{358}$ DF 247901.

${ }^{359}$ MTHJ III. 556-557.

${ }^{360}$ MTHJ III. 552-556., 610-615.
} 
A máramarosi mezővárosokban is láthatólag a helyi szokásjog alapján történhetett a mindennapok ügyeinek intézése. Nem véletlen, hogy 1480-an Huszton az elővásárlási jogot iuxta morem civitatis szeretnék alkalmazni, a már említett borméréssel kapcsolatos oklevélben pedig 1517-ben ugyanott a bor árának meghatározása történik a régi szokások szerint ( $a b$ antiquo consuetudinem). ${ }^{361}$

${ }^{361}$ DF 285466, DL 84631. 


\section{A MEZŐVÁROSOK LAKÓINAK TÁRSADALMI-GAZDASÁGI HELYZETE}

Ha máramarosi mezővárosaink középkori társadalmi és gazdasági képét szeretnénk jellemezni, nem vagyunk egyszerü helyzetben, mivel csak szórványadataink vannak erre nézve. A 16. század közepétől - de legalább is a 16-17. század fordulójától - a máramarosi városokból már olyan források is egyre inkább rendelkezésre állnak a társadalmi és gazdasági viszonyok megismeréséhez, amelyek akár statisztikai módszerek segítségével is feldolgozhatók, és így komplex képet tudnak nyújtani például a vagyoni rétegződésről vagy a foglalkozási viszonyokról is. ${ }^{362}$

A középkorral kapcsolatosan azonban egészen mások a lehetőségek. És itt nem a források számáról van elsősorban szó. A sóvágok statútumai például részletesen beszámolnak az aknákban végzett tevékenységükről, a munkaszervezetükről vagy a jövedelmeikről is, de mélyen hallgatnak a mindennapjaikról. Nem lehet őket a városi társadalomban elhelyezni, sem helyileg (mert szinte egyáltalán nincs adat az ingatlanjaikra, sem telekre sem másra), sem szociális értelemben (mert semmit sem tudunk arról, hogyan pozicionálódtak a mezővárosi közösségen belül, csak annyit, amenynyit a statutumokból kiolvashatunk). Ugyanez a helyzet a mezővárosok (Sziget kivételével) alapvetően agrártevékenységgel és emellett mellékjövedelmi forrásként sófuvarozással foglalkozó lakosságával is, akik szinte egyáltalán nem jelennek meg oklevélben, noha nyilvánvaló, hogy a határjárásokban sokszor feltűnő szántók és legelők szolgáltathatták megélhetési alapjaikat.

\footnotetext{
${ }^{362}$ Glück László élve a források adta lehetőséggel módszertanilag is újszerű megközelítéssel dolgozta fel disszertációjában a 16-18. századi máramarosi társadalmi fejlődést. Glück 2013.
} 
Valójában egyetlen társadalmi csoportról lehet ennél csak egy kicsivel is többet elmondani. Ezek a Huszton és Szigeten ingatlanokat szerző, a kamarai igazgatásban dolgozó, eleve nemesi származású vagy a kamarai karrierre támaszkodva nemesi címet szerző, a polgárok közül vidéken birtokot vásárló személyek. A birtokügyeikkel kapcsolatos okleveleik ugyanis szerencsére sok esetben fennmaradtak. Azok az alsóbb rétegek viszont, akik nem vettek maguknak ingatlanokat a környéken - mert nem tehették meg -, vagy nem szerepeltek a kamarai igazgatásban, a legtöbb esetben „láthatatlanok" az írott forrásokra támaszkodó kutató számára.

Ennél jóval kevesebbet tudunk a máramarosi kézművesrétegről, de ők legalább fel-felbukkannak a forrásokban. Szerepük értékeléséhez és az országos helyzettel való összevetéséhez azonban tenni kell előbb egy kis kitérőt. A középkori városi és mezővárosi ipar fejlődésének kérdése már régóta foglalkoztatja a magyar középkortudományt. Az 1950-es évektől napjainkig sikerült azokat a főbb jellegzetességeket meghatározni, amelyek összefoglalóan leírhatják a középkori magyar iparfejlődés legfontosabb sajátosságait.

Az egyik ilyen, hogy a kézművesek főleg a városias településeken telepedtek meg, és az iparral foglalkozók aránya a civitasokban általában magasabb volt, mint az oppidumokban ${ }^{363} \mathrm{Az}$ is nyilvánvaló, hogy a mezövárosok fejlettebb iparral rendelkeztek a falvaknál, és a falusi kézművesek a jobb érvényesülési lehetőségek miatt nagy számban költöztek be a környékbeli oppidumokba. ${ }^{364}$ Azaz: a településen tevékenykedő kézművesek száma egyenes arányban áll a városfejlődésben elért szinttel.

A különbség az eltérő településtípusok között azonban nem csak számszerü: minél jelentősebb egy település, annál sokrétűbb fogyasztói igények jelennek meg ott, így annál magasabb szintü a szakmák specializációja is. ${ }^{365} \mathrm{~A}$ kutatás általános megállapításai szerint a falutelepüléseken leginkább a közszükségleti és tömegcikkekre mutatkozik igény a lakosság részéről, az oppidumokban a kereslet bővül és színesebbé válik, míg a civitasok lakói a különféle kézműipari, sok esetben „luxusipari” (így pl. ötvösipari) termékek széles palettáját vásárolják meg. Ennek megfelelően a megjelenő szakmák száma is egyre magasabb lesz, ahogy felfelé haladunk a települések hierarchiájában.

Ami a számszerü adatokat illeti: a civitasokban a kézműves lakosság aránya általában 20-30 \%-ot tett ki a lakosság körében, az iparágak száma pedig településenként akár az 50-60-at is elérhette. A mezővárosokban a lakosságnak nagyjából 15-20\%-a volt kézmúves, akik a legtöbb esetben

\footnotetext{
${ }^{363}$ Szűcs 1955. 95-101; Bácskai 2002. 47-49; Szende L. 2008. 206-208.

${ }^{364}$ Bácskai 1965. 35-36.

${ }^{365}$ Szűcs 1955. 66-82; Kubinyi 1973. 54; Bácskai 2002. 47-49.
} 
6-7 iparágat képviseltek saját lakóhelyükön. A városi és mezővárosi kézmüipar közötti különbség főleg minőségi jellegű volt, és a szakmák differenciáltságában mutatkozott meg, míg a mezővárosi és falusi kézműipar között elsősorban mennyiségi volt az eltérés: több kézműves és nagyobb árumennyiség figyelhetố meg az oppidumokban, mint az egyszerű falvakban. ${ }^{366}$ De nem szabad arról sem megfeledkezni, hogy a mezővárosokban és a falvakban a kézművesek egy jelentős része, talán fele-kétharmada nem hagyott fel teljesen a mezőgazdasági termeléssel sem, azaz nem tekinthető olyan iparúzőnek, aki kizárólag a szakmájából él, mellette szükségszerüen mezőgazdasági termeléssel is foglalkozott. ${ }^{367}$

A magyar várostörténet-írás a középkorra vonatkozólag főként a jobbágyok és polgárok foglalkozásnévből képzett megkülönböztető neveinek segítségével szokott adatokat nyerni a kézmüiparral kapcsolatosan, feltételezve azt, hogy a vizsgált személy neve még nem vált öröklődő családnévvé, s így nem csak a felmenőire, hanem rá nézve is használható adatként szolgál. Középkorászaink a 15. század tekintetében elfogadják az ilyen nevek erre a célra történő felhasználhatóságának lehetőségét, azaz, ha például valakit Stephanus fabernek vagy Johannes Kowacznak neveztek a források, azt a személyt iparűzőnek, kovácsnak szokás tekinteni. ${ }^{368}$

Ha a fenti bevezetés ismeretében nekifogunk a máramarosi mezővárosok középkori iparfejlődésének vizsgálatához, szinte rögtön konstatálni kell, hogy a középkori máramarosi ipar helyzetének megismerése a koronavárosokban megfelelő mennyiségű forrás híján igen nehéz. Az öt királyi mezővárosból 86 városlakó nevét sikerült összegyűjtenem a középkor századaiból, ami nem sok, ráadásul nagyon aránytalan is az eloszlását tekintve. Ezek nagy része ugyanis a két legjobban adatolható településünkről, Husztról és Szigetről származik, míg például Viskről csak négy polgár neve ismert. Tehát eleve kevés adattal tudunk csak dolgozni. Természetesen a jövőben még kerülhet elő néhány, eddig lappangó személynév, de véleményem szerint nagy áttörés már nem várható már ezen a téren. ${ }^{369}$

\footnotetext{
366 Szűcs 1955. 99; Bácskai 1964. 6-8.; Granasztói 1972. 389; Bácskai 2002. 36; Skorka 2005. 109-112.

${ }^{367}$ Bácskai 1965. 38-39.

${ }^{368}$ A legfontosabb munkák erre a bonyolult kérdéskörre nézve: Székely 1967; Kubinyi 2003., illetve a vonatkozó szakirodalom ismertetésével Gulyás 2008b.

${ }^{369}$ Csak azokat vettem városlakónak, akikről pontos adat van erre nézve. Nyilvánvaló, hogy a kamarák alkalmazottai - akikre ilyen adatunk sokszor nem áll rendelkezésre - föleg a két fejlettebb városban, Szigeten és Huszton élhettek, de nem tudjuk eldönteni, hogy valóban megtelepedtek-e ott, ezért ezeket nem vettük be az oppidanusok közé.
} 
Jelenleg - a literátusokat leszámítva - öt huszti, három szigeti és egy hosszúmezei lakos foglalkozását ismerjük. Huszton volt kovács (faber, 1478), szíjgyártó (corrigiator, 1480), két szabó (Zabo, sartor, 1478-1480) és fazekas (ollipar, 1521). ${ }^{370}$

Szigeten dolgozott szücs (pellifex, 1459), kovács (Kowach, 1515) és van egy személy, akinek a megkülönböztető neve (Wago, 1519) mutatja, hogy itt egy sóvágóról lehet szó. ${ }^{371} \mathrm{Ez}$ az egyetlen olyan személynevünk egyébként, amely alapján ilyet feltételezhetünk, a sóvágók csak a királyi statútumokban szerepelnek, általánosságban, mint közösség említve. ${ }^{372}$ Hoszszúmezőn 1456-ból Nyerges (Nerges) Tamás nevét ismerjük, aki ekkor a település bírája volt. ${ }^{373}$

Mire elégséges ez a néhány adat? Arra semmiképpen nem, hogy a kézmúvesség lakosságon belüli arányát vizsgáljuk a segítségükkel, hiszen ahhoz túlságosan kevés névvel rendelkezünk. Arra azonban halványan utalhat, hogy a máramarosi kézmủipar fejődése nem érte el az igazán jelentős mezővárosok szintjét. Ezek a mesterségek egytől-egyig azokat a közszükségleti cikkeket állították elő, amelyeket a falvak népessége is rendszeresen vásárolt, nem pedig olyanokat, amelyek egy igazán fejlett településen már megjelentek. Ez alól talán leginkább Huszt jelenthetett kivételt, ahol az uradalmi központ kapcsán aránylag nagy számú „úri” réteg és egyéb, az uradalomban alkalmazásban álló fogyasztócsoportok is megjelenhettek.

A szíjgyártó, a nyerges és a szűcs jelenléte logikus, hiszen nyilvánvalóan a környékbeli hegyekben tevékenykedő, magyar, de főleg román és rutén pásztorok által szállított bőrt dolgozták fel. ${ }^{374}$ Kovács pedig minden faluban van, ahogy szabók és fazekasok is. Ezek tehát mind tömegtermékeket állítottak elő. Ami a kézmüvesek arányát illeti, véleményem szerint nyilvánvaló, hogy ennél a durván 10 \%-nál nagyobb arányban élhettek a településeken. Elég, ha csak a környékbeli uradalomra és a bányákra gondolunk, ahol számos kézmúves találhatott magának tennivalót.

A kézmüipar nem túl magas fejlettsége mellett megjegyzendő, hogy olyan forrás sincs a korból, amely azt mutatná, hogy megindult volna a térségben a céhes szerveződés. Az első ismert céhek a városokban csak az újkorban jelentek meg: Szigeten és Técsőn a vargák (1597-ben és 1652-ben),

${ }^{370}$ DL 70984, DF 285466, DL 47398.

${ }^{371}$ Már. Dipl. 429., DF 212593, DF 212557.

${ }^{372}$ Ez alól kivételt jelent még egy 1505. évi testamentum, amelyben Máté sóvágóbíró tanúként szerepelt. DL 84083.

${ }^{373}$ DF 247899.

${ }^{374}$ A városok környékén a románság is foglalkozott iparüzéssel. A juhtenyésztésből adódóan rendelkezésre álló gyapjú révén bekapcsolódtak ugyanis a szövőiparba, mégpedig a viszonylag alacsony minőségű és egyszerű termékeket előállító szürkeposztó-készítésbe. Ezt a tevékenységüket környékbeli földrajzi nevek is bizonyítják. Ilyen például a "Szukna” (= posztó) vagy a „Gyapjúpataka” elnevezés. Pach 2001. 799-803. 
valamint Huszton a csizmadiák (1682-ben) hozták létre az első céhszervezetüket. ${ }^{375}$ Egészen más ugyanakkor a sóvágók helyzete, akik jogilag és társadalmilag is élesen elkülönültek a mezővárosok többi lakójától, és szükség esetén összefogtak, például a béremelés érdekében.

Ezeknél a forrásoknál sokkal jobb lehetőségeket kínál a kézműipar és a foglalkozási viszonyok vizsgálatához az 1600. évi urbárium, amely nagy számban sorolja fel a helyi lakosok neveit. Glück László érdekes és újszerü, komplex megközelítésmóddal részletesen vizsgálta ezt a forrást. Ebben számos tényezőt figyelembe vett, így például az állattartást vagy a sókereskedelmet is, és ennek köszönhetően a „vegyes”, azaz több lábon álló egzisztenciákat is jól ki tudta mutatni. Vizsgálatai alapján Sziget a foglalkozási viszonyok alapján kiemelkedik a többi közül, amelyet ebből a szempontból a sokkal inkább agrárjellegű Huszt és Visk követ. Técső nem mérhető már ehhez a kettőhöz sem, míg Hosszúmező mindezen szempontok alapján gyakorlatilag falunak veendő. ${ }^{376}$ Eredményei nem cáfolják tehát meg azt a képet, amely a középkori máramarosi iparfejlődésről a forrásokból kirajzolódik.

A társadalomtörténet szemszögéből a legélénkebb képet Husztról és Szigetről kapjuk. A két mezővárosnak a 15. század végére egyrészt jelentős nemesi népessége, másrészt viszonylag nagyszámú literátus lakója volt, $\mathrm{s}$ a két réteg sokszor össze is fonódott, azaz a literátusok egy része a nemesség köréből került ki. A litteratusoknak két csoportja van. Az egyik a helyi, vagy környékbeli értelmiség, de vannak olyanok is, akik az ország távoli pontjáról - néha kifejezetten messziről - érkeztek Máramarosba, hogy a kamarában karriert csináljanak meguknak. Mindkét jelenség - a nemesek és a diákok nagy súlya a helyi társadalomban - nyilvánvalóan a kamarai igazgatással állhat kapcsolatban: itt a kamara alkalmazottairól van szó.

A környékbeli nemesség betelepedése már Zsigmond uralkodásának első szakaszában megkezdődhetett. 1408-ban arról van adatunk, hogy Baranyai Lukács fia Lőrinc és fiai a Huszt folyón malommal, Huszton pedig curiával is rendelkeztek. Igaz, nem tudjuk, hogy meg is telepedtek-e tartósan a városban, de könnyen elképzelhetö. ${ }^{377}$

\footnotetext{
${ }^{375}$ Sziget: Szádeczky 1913. II. 280; Técső: Szádeczky 1913. II. 313; Huszt: Szádeczky 1913. II. 266; Vö. Glück 2013. 363-364.

${ }^{376}$ Glück 2013. 128-158.

${ }^{377}$ Mivel a család ezzel kapcsolatos korábbi iratai elvesztek, Zsigmond megparancsolja a leleszi konventnek, hogy írják át az erre vonatkozó okleveleket. Már. Dipl. 156-157. Baranya közvetlenül Huszt mellett található. Urai rendszeresen szerepelnek a megyében királyi emberként. Elsőként 1397-ben van róluk adatunk: Baranyai vagy Erdői Nagy Pál („Paulus magnus de Baranya aut Erdew") határjáráson szerepel. Már. Dipl. 117. 1415-ben Baranyai Lőrinc birtokiktatáson vesz részt. Már. Dipl. 202. 1419-ben Baranyai István és János tanúkihallgatáson. Már. Dipl. 241. Stb.
} 
Gyakoribbnak tűnik azonban, hogy a városokból kiindulva próbálnak meg a lakók nemesi birtokot szerezni. Ezt a réteget testesíti meg a Dózsaféle mozgalomban részt vevő és ezért birtokelkobzásra ítélt Huszti, más néven Keselyümezei Benedek. Javai, akárcsak a környékbeli és hasonlóképpen kompromittálódott, fóleg román eredetű nemeseké, 1514-ben a királyra szálltak, aki Werbőczy Istvánnak adományozta azokat. ${ }^{378} \mathrm{~A}$ Keselyűmezei család egy viszonylag későn nemességet szerző huszti eredetű família volt.

1483-ban a szintén huszti Korpádi Benedek litteratus az Úrmezeiektől a környékbeli Lipcsén található részbirtokot vásárolt meg. ${ }^{379}$ Benedek leszármazottja lehetett az a Korpádi Ferenc nevü huszti lakos, akinek telke már Beatrix királyné kegyéből is adómentes, s ennek jogán személye egyúttal mindenféle szolgálattól, vámfizetéstől, sókivetéstől és szállítási kötelezettségtől szabad volt. A királynőtől malomépítési jogot is nyert, amivel azonban az 1520-as évekig még nem élt. Mivel az ezzel kapcsolatos oklevelet elvesztette, Mária királynétól a privilégium megerősítését kérte, amit - tekintettel az adományos által a kamarának tett hüséges szolgálatokra - 1523-ban meg is kapott. Mária egyúttal azt is bevette a kiváltságok közé, hogy azok a leszármazottaira is érvényesek, és kivette őket a huszti tanács joghatósága alól is. Ferenc az oklevél megjegyzése szerint egyébként már egyértelműen nemes volt, de rokonáról, Benedekről még nem rendelkezünk ilyen információval. A nemesi cím megszerzése valószínűleg a Beatrix-féle kiváltságolással kapcsolatosan történhetett. ${ }^{380}$

Lipcsén szerzett egy pusztatelket, valamint Herincsén négy telket és egy pusztatelket 24 forintért zálog gyanánt a szintén huszti Nagy Albert az Ilosvaiaktól 1487-ben. ${ }^{381}$ Az Ilosvaiaik 1489-ben herincsei javaikból további

${ }^{378}$ DL 72159. Benedek neve alapján egyértelmű mind a huszti lakóhely, mind a Keselyümezeiekkel való rokonság: „Benedicti litterati de Hwzth alias de Keselewmezew”. Keselyűmező Huszttól északra található. A Keselyümezeiek a 15. század közepén tünnek fel a környéken. 1450-ben Simon huszti plébános és máramarosi püspöki vikárius is a családból származott. Ekkor iktatják be Hunyadi János kormányzó parancsa alapján testvéreit, Keselyümezei Jánost és Pált Keselyümező egész, Lipcse és Herincse részbirtokába. Nemességszerzésük is ezzel a birtokszerzéssel függhet össze. Már. Dipl. 344. A karriernek azonban gyorsan vége szakadt, mert mint kiderült, Keselyümező a Bilkeiek keneziátusának területén fekszik, s emiatt Bilkei Miklós panasszal élt, aminek a király helyt adott és visszavonta az adományát. Ekkor Simon mellett a testvérei is a városban laktak. Talán a Bilkeiekkel való konfliktus késztette őket erre. Már. Dipl. 399. Több nemesi birtokukról nincs konkrét adatunk, az 1514. évi oklevél nem sorolja fel sem az ők, sem a többi kegyvesztett nemes birtokait, de ezek szerint rendelkeztek ilyennel, nemesi nevüket és nyilván nemesi státusukat még fél évszázaddal később is őrizték.

${ }^{379}$ DL 45947.

${ }^{380}$ DF 247947. Kiváltságait az oklevél indoklása alapján „ratione domus sue” viselte, azaz itt a telek nemesi jogúvá tételéről lehet szó.

${ }^{381}$ DL 66731. 
három telket és egy pusztatelket, Lipcsén pedig két telket zálogosítottak el 50 forintért a huszti polgár Theremy Albert literátusnak. ${ }^{382}$ 1492-ben a huszti Pecsétes Bálintot a nyalábi birtoktesttel szomszédos birtokosként sorolták fel, azaz valahol Huszt délnyugati határában feküdhettek a birtokai. $^{383}$

A literátusok között meg kell még említeni a szintén huszti Ferencet, akinek a neve 1514-ben szerepel oklevélben. ${ }^{384}$ Az 1498-ban említett és a huszti várban dolgozó Ilmeri Pál litteratus huszti faktor is talán a huszti polgárság köréből kerülhetett ki. ${ }^{385}$

A máramarosiak közül a szakirodalomban legismertebb polgár a szlavón (goricai) nemesi származású sókamarai tisztségviselő, huszti Barilovics (Dolgos) Miklós volt. Házzal rendelkezett Nagybányán és Huszton, prediális nemesi címet szerez, Huszton malmot épít, de a Farnas-patakon és Técsőn is van malma. Szőllősön eközben több nagyobb szőlőt szerzett, egészen pontosan 16-ot, mégpedig csaknem 400 forint értékben. Újlakon telket, Hetényen vízimalmot és telket sikerül megkaparintania. Otthonában, Huszton - egyedülálló módon - szabadon és a bírói árszabás mellőzésével árulhatja borát. ${ }^{386}$

A másik fontos mezővárosban, Szigeten is hasonló társadalmi kép fogad bennünket. 1435-ben Zsigmond király megengedte a szigeti Fábián fia Henkel Balázsnak és testvérének, Mártonnak, hogy a Tisza és az Iza folyón malmot építsenek, és azt örökjogon birtokolják minden jövedelmét élvezve, egyúttal a máramarosi ispánt és a huszti várnagyot felszólította, hogy a malommal kapcsolatos jogaikban a testvéreket védjék meg. ${ }^{387}$

Szintén írástudó és egyben birtokos volt Szigeti Péter litteratus. 1459 novemberében I. Mátyás parancslevelében felszólította a leleszi konventet, hogy vezesse be királyi adományként Pétert a Sziget melletti, Rónaszékkel, Disznópatakkal és Barcánfalvával határos Sydepataka prédium birtokába. A leleszi konvent oklevele alapján ez meg is történt. ${ }^{388}$ Máramaros megye 1460. január 3-án keltezett oklevele szerint a birtokba való beveze-

${ }^{382}$ DL 66735. Theremy Albert és testvére, Ambrus már 1485-ben feltünik hasonló szerepben. Ekkor a Herincse melletti Chaholtzpathaka völgyet szerzik meg vásárlás útján. Már. Dipl. 566-567.

${ }^{383}$ DL 71039. Perényi 647. sz. Pecsétes Bálint a neve alapján nyilvánvalóan a huszti kamara alkalmazottja, sigillatora lehetett. A sigillatorok feladata az „officium sigillationis” ellátása volt, amelyről fentebb már esett szó. Iványi 1911. 21.

${ }^{384}$ DL 86747.

${ }^{385}$ DL 71072. Perényi 689. sz.

${ }^{386}$ A részletezéstől eltekintenék, mert a kutatás alaposan feldolgozta már Miklós életét. Bácskai 1965. 118; Szakály 1985; DL 38452, DL 38466, DL 65372, DL 71072, DL 46994, 73364. Vö. Glück 2013. 54-55.

${ }^{387}$ DL 24953.

${ }^{388}$ DL 15414. 
tés december 30-án ment végbe. ${ }^{389}$ Péter minden bizonnyal kapcsolatban állhatott a kamarával, mivel a birtokadomány ügyét Istenmezei Albert sókamaraispán terjesztette a király színe elé. ${ }^{390}$ A család leszármazottai a 16. század közepén is nemesként szerepelnek a forrásokban. ${ }^{391}$ Az 1460. évi megyei kiadvány azért is fontos, mert ez alapján a szomszéd birtokosok szintén szigetiek voltak. Megemlítik itt Orsoly Tamást, Kosa Gergely és Syle Pencz szigeti civiseket is.

Királyi szolgálatban nyert el nemességet 1515. május 3-án Szigeti Bertalan deák, akinek szigeti telkét II. Ulászló nemesi joggal ruházta fel és minden adótól és servitiumtól felmentette. ${ }^{392}$ 1491-ben Beatrix királyné egy helyi - valószínüleg polgári származású - pap, szigeti Tamás litteratus fia, Pál szigeti presbiter számára engedélyezte, hogy a település mellett malmot építhessen. ${ }^{393}$ Ez egyértelmű adat arra nézve, hogy a literátusréteg valószínúleg újratermelte magát, azaz sokszor a deákok gyermekei is bizonyosan jártak valamilyen iskolába.

Ismerünk még egy nemesítést Szigetről. 1519. május 23-án II. Lajos nemesi címmel ruházta fel Szigeti litteratus Györgyöt és testvérét Pétert, egyúttal felszólította a leleszi konventet, hogy iktassa be őket a Szigeten lévő kúriájuk birtokába, amit a nemesítéssel együtt kivett minden szolgáltatás alól, azt nemesi kúriává téve. Nem akárkiről van szó: nemesi címét az ország védelmében folytatott harcokban és kancelláriai jegyzőként tett szolgálatai során érdemelte ki, és nemesítéséért egykori főnöke, Szalkai László váci püspök és főkancellár járt közben az oklevél indoklása szerint. Emellett címeradományt és két malom építésére szóló engedélyt is kapott. A birtokba a leleszi konvent 1520. január 4-én keltezett oklevele alapján az

\footnotetext{
${ }^{389}$ DL 15428. Átírva Péter kérésére a megye 1461. évi oklevelében.

${ }^{390}$ DL 15414. Ahogy a királyi oklevél fogalmaz: a király „,ad humilime supplicationis instantiam fidelis nostri egregii Alberti de Istenmezeye comitis camerarum nostrarum Maramorosiensium, per eum pro parte fidelis nostri Petri litterati de Zygeth" döntött az adományról.

${ }^{391}$ A birtokadományra és a későbbiekre lásd Glück 2013. 190-192.

${ }^{392}$ Az oklevél közepe kiszakadt, ezért a szövegből jelentős rész hiányzik, de ez a leleszi konvent jelentéséből kiegészíthető. DF 212557: Bertalan és rokonságának kérése a következő volt:,,Exponitur maiestati nostre in personis nobilis Bartholomei litterati de Zygeth ac Iohannis fratris eiusdem necnon Sophie sororis eorundem, quomodo... cuiusdam integre sessionis sew fundi curie ipsorum in oppido nostro Zygeth vocato in comitatu Maromorosiensi existente habite... tamque nobilitaris et exempte, quam... ab omni onere solutionis annuarum taxarum et servitiorum perpetuo exemissent et libertassimus (!) legitime vellent introire" stb. A király a kérésnek eleget tett, és felszólította a leleszi konventet, hogy vezesse be Bertalanékat a ház birtokába, ami a konvent ugyanezen év július 19-én II. Ulászló idézett oklevelének aljára írt fogalmazvány alapján meg is történt. A konvent jelentése a királynak néhány nappal később, július 24-én kelt. DF 212593.
}

${ }^{393}$ DL 83957. 
érintetteket be is iktatták. ${ }^{394}$ Szigeti György kancelláriai jegyző, korábban pedig végvári vitéz volt, s ezután került a máramarosi sókamarába, pályája tehát mezővárosi szemmel nézve közel sem szokványos. A karrierjéről még annyit tudunk, hogy 1521-ben már huszti várnagyi címet viselt. Ekkor huszti házát Csebi Pogány Zsigmond máramarosi alispán ugyanott álló házával cserélte el. Azaz, amikor huszti várnagyként Szigetről Husztra került, ott is vásárolt magának egy lakóházat. ${ }^{395} \mathrm{Az}$ sem lehet véletlen, hogy az épület a mezőváros főterén (in theatro oppidi Hwzth) állt. Ennek valószínüleg még egy oppidumban is lehetett némi presztízsértéke.

Az iparosokra nézve - mint azt láttuk - jóval kevesebb adat van, mint a literátus-nobilis rétegre. A legtöbb információra ebből a körből egy bizonyos János kovácsról rendelkezünk. ${ }^{396}$ Igaz, amikor feltünt a forrásokban, már nem élt, hátrahagyott ingó és ingatlan javai azonban komoly fejtörést okoztak az utódoknak. A huszti magisztrátus előtt - akik az ezzel kapcsolatos oklevelet is kiállították - 1478-ban egy hagyatéki per zajlott, amelynek tárgya az elhalt kovács javai voltak. Aranyani Péter huszti plébános, egyúttal máramarosi vikárius ugyanis a néhai János kovács fiától, János literátustól, aki apja ingó és ingatlan javait örökölte, megvette a hagyatékot. A vételárat az oklevél sajnos nem említi meg (pro certa pecuniarum).

A javakat azonban a rokonsághoz tartozó szőllősi polgárok: Nyerges Péter és felesége, Dorottya, valamint Calmar János és felesége, Erzsébet nem adták ki Aranyani Péternek. A vikárius ezért perbe hívta a szőllősieket, és a pert végül döntőbírák útján oldották meg. Kiderül az oklevél-

${ }^{394}$ Az eredeti királyi oklevél (DF 212556) szakadozott és foltos, a halvány fényképmásolatból sok helyen teljesen olvashatatlan. A nemesítés és az indoklása a leleszi konvent 1520. évi átiratából (DL 47336) a következő: „Cum nos attentis et considerantis fidelitate et fidelibus servitiis fidelis nostri nobilis Georgii litterati de Zygeth notarii cancellarie nostre, que ipse uti didicimus sacre imprimis huius Regni nostri Hungarie Corone et deinde maiestati nostre cum in profligenda et fudenda feda rusticorum in pernitiem nobilitatis superiori tempore conspirata manu strennue pugnando, tum vero in cancellaria nostra post dominum suum reverendum Ladislaum episcopum Vaciensem cancellarium nostrum pro locorum temporumque diversitate exhibitis accedente, et sui, etiam domini episcopi supplicatione, eundem Georgium litteratum et sui gratia Petrum fratrem eius uterinum, in numerum ac cetum et armis utentes huius Regni nobilium adhibitis certis nobilitatis in quibus vigore aliarum litterarum nostrarum superinde conspectarum ascripserimus, domumque eorundem presentiam in predicto oppido nostro Zygeth... sitam et habitam... de potestatis nostre regie plenitudine transformaverimus ac premissis --- nove nostre donationis titulo eisdem Georgii litterato et Petro ipsorumque heredibus et posteritatibus universis simul cum cunctis utilitatibus et pertinentiis ad eandem domum de iure et ab antiquo spectantibus et pertinere debentibus in perpetuum contulerimus, velimusque eosdem in dominium eiusdem per nostrum et vestrum homines legitime facere introduci.". Ismert az oklevélnek egy koraújkori másolata is. (DL 25009). Györgyre lásd: Glück 2013. 192-193. A címerképet ismerteti: Armális 1899.

${ }^{395}$ 1521-ben már várnagyként cseréli el huszti házát Csebi Pogány Zsigmond alispán ugyanottani házával. DL 47398.

${ }^{396}$ János kovács hagyatékainak ügyét ismerteti Glück 2013. 159-161. 
ből, hogy a kovácsnak négy gyermeke volt: János deák mellett az említett Dorottya és Erzsébet, illetve még egy fiú, a még kiskorú Kristóf klerikus (Cristophorus clericus). A döntőbírák határozata alapján a hagyatékot végül négy egyenlő részre osztották, melyből a vikárius csak János deák részét kaphatta meg, a többit azonban nem. ${ }^{397}$ János kovács a kézműveseknek azt a jómódú rétegét képviselte, aki gyermekeit taníttatni tudta. Ezt János nevü fiának literátus, és Kristóf clericus jelzője bizonyítja. Igaz, utóbbinak a neve mellett 1480-ban már nem szerepel a kifejezés, azaz elképzelhető, hogy végül feladta a tanulmányait és nem sikerült bejutnia a literátus rétegbe. Máramarosban a tanulás jó karrierlehetőség volt, hiszen a kamaránál ezek a képzett emberek munkát találhattak maguknak.

Egy másik oklevélből a malom későbbi, de korábbi történetére is van adatunk. Két évvel később ugyanis megjelent a huszti tanács színe előtt Anna asszony, aki korábban az azóta elhalálozott Arday Lőrinc felesége volt, jelenleg pedig a szintén huszti Máté szíjgyártó felesége, és a következőt adta elő. Tudniillik, hogy Péter plébános a malomrészét, amely a néhai Arday István malmában van, és amit János kovács lányaitól, Dorottyától és Erzsébettől, illetve fiaitól: János literátustól és Kristóftól, valamint Tamás szabótól és Kósa Antaltól vásárolt, el akarja adni Albert huszti sókamarásnak, amit azonban Anna (nyilván rokoni elővásárlási jog alapján és a város szokása szerint) tiltott, és meg akarta a malmot vásárolni. A tanács azonban elutasította a kérelmet, és eltiltotta Annát attól, hogy Albertet a malom birtokában zaklassák. ${ }^{398} \mathrm{~A}$ malmot ez alapján tehát az Ardayak építhették, s annak ellenére, hogy többször gazdát cserélt, még a 16. század elején is Arday-malomnak nevezték a husztiak. ${ }^{399} \mathrm{~A}$ fenti életpályaszilánkok után nézzük, hogy milyen a mezővárosok általános társadalmi képe. Ha a rendelkezésre álló, sajnálatosan kevés forrás alapján a tulajdonviszonyokat, a jogi státust és a kézműves-tevékenységet egymás keresztmetszetébe állítjuk, akkor a következő képet kapjuk:

\footnotetext{
${ }^{397}$ DL 70984, Perényi 578. sz. Az oklevél sajnos csak általánosságban sorolja fel a javakat: „arabiles (!) ac prata seu feneta... fenilia necnon ceteras res et bona, ac pecunia, domus, molendina, terras" stb.

${ }^{398}$ DF 285466.

${ }^{399}$ Glück 2013. 168., 361. jegyzet.
} 


\begin{tabular}{|l|c|c|c|c|c|}
\hline & Összesen & $\begin{array}{c}\text { Tanács- } \\
\text { tagság }\end{array}$ & $\begin{array}{c}\text { malom- } \\
\text { birtoklás }\end{array}$ & $\begin{array}{c}\text { egyéb } \\
\text { birtoklás }\end{array}$ & $\begin{array}{c}\text { mindkettő } \\
\text { birtoklása }\end{array}$ \\
\hline nemesek & 7 & 0 & 3 & 3 & 0 \\
\hline $\begin{array}{l}\text { litteratus- } \\
\text { nemesek }\end{array}$ & 7 & 0 & 0 & 3 & 1 \\
\hline litteratusok & 10 & 1 & 3 & 2 & 0 \\
\hline kézművesek & 8 & 3 & 1 & 0 & 1 \\
\hline egyéb polgárok & 54 & 14 & 5 & 9 & 0 \\
\hline Összesen & 86 & 18 & 12 & 17 & 2 \\
\hline
\end{tabular}

A fentiek alapján leginkább a foglalkozási és a tulajdonviszonyok oldaláról közelíthetjük meg a középkori máramarosi társadalomfejlődés kérdését. Azt látjuk, hogy a mezővárosi vezetőréteget a helyi kamarai igazgatásban tevékenykedő és különféle tisztségeket viselő vagy eleve nemesi származású, illetve később nemessé váló polgárság jelentette. Ugyanide tartoznak azok a literátusok is, akik nemesi címet nem szereztek ugyan, de a kamarai munkájuk révén bizonyosan nem csekély bevétellel rendelkeztek. Ezek csak három városban telepedtek meg. ${ }^{400}$ Ök azok, akik a lakosságon belüli arányukhoz képest ingatlanbirtoklás terén kiemelkedtek a mezővárosi társadalomból. A városokból összesen 12 malomtulajdonost ismerünk, ezeknek kereken a fele az ő köreikből került ki, miközben a lakosságon belüli arányuk az egyharmadot sem érte el. Az összesen ismert 31 ingatlanbirtokos közül 15 az ő soraikban található. A kevés adat ellenére is úgy vélem, a birtokok nagy része az ő kezükben összpontosult. A másik lényeges tapasztalat, hogy a nemes és nem nemes literátus réteg - szemben a már sokszor dokumentált országos helyzettel ${ }^{401}$ - szinte egyáltalán nem érdeklődött a máshol oly megbecsült magisztrátus iránt. A nemesek közül senkit nem ismerünk, aki tanácstag lett volna, a literátusok közül is mindössze egyetlen személy. Nem véletlen: a máshol oly nagyra értékelt tanácstagság (a bírságpénzekkel és egyéb kedvezményekkel) itt nem tudta felvenni a versenyt a kamara által nyújtott járandóságokkal, a sójáradékokkal és nem utolsósorban a társadalmi felemelkedés lehetôségével. Utóbbihoz csak annyit tegyünk még hozzá: a nemesek számának lassú növekedése a máramarosi mezővárosokban a 16. században is tart, majd a 17. századra a városok közül a legjelentősebbek lakossága nagymértékben elnemesedik. ${ }^{402}$

\footnotetext{
${ }^{400}$ A literátusok Huszton és Szigeten kívül csak ritkán jelennek meg. Hosszúmezőről ismerjük még Csonka (mancus) Péter deákot, DL 90433; Deak Miklóst és Demeter literátust. Már. Dipl. 403., 429.

${ }^{401}$ Lakatos 2013. 86-89.

${ }^{402}$ A kérdést kimerítően tárgyalta Glück 2008a.
} 
A literátusok nagy aránya sem szokványos. ${ }^{403}$ Ha figyelembe vesszük, hogy a források bizonyosan jelentősen torzítanak, hiszen azokban csak az ingatlanügyek résztvevői szerepelnek, akkor is kiemelkedően magas a deákok aránya a lakosságon belül (a 86 ismert polgárból 17).

Ezt az állítást megerősíti egy nemrégiben elvégzett vizsgálat eredménye. Csaknem 12 ezer 15-16. századból oklevélben fennmaradt polgári és jobbágyi személynévből - amelyek Magyarország szinte teljes területéről származnak - összesen 103 volt az olyan megkülönböztető név, amely müveltségre utalt (Deak, Dyak, litteratus, scholasticus, rector schole, baccalaureus stb.). Ez pedig országos szinten nagyjából 0,86\%-ot tesz ki. Persze az egyes településkategóriák között vannak eltérések, így a falvakban ez az arány csupán 0,4\%, míg püspöki székhelyeken 3,5\% ${ }^{404}$ Tehát, ha a források jellegéből adódik is némi torzulás, kijelenthető, hogy a koronavárosokban messze az országos átlag felett van az értelmiség aránya.

A másik nagy társadalmi csoport a kézmúveseket tömöríti. Ők már részt vesznek a tanácsban, a bírói vagy esküdti cím a helyzetükben értékes tényező. A harmadik réteget a sajátos helyzetü, külön kiváltságokat élvező és állandó jövedelmet húzó, ráadásul sóval is kereskedő sóvágók alkották, akik egyáltalán nem szerepelnek a forrásaink alapján az ingatlanforgalomban.

Az utolsó, agrárius jellegü és az országos helyzethez hasonlóan mezőgazdasági árutermeléssel foglalkozó társadalmi rétegről nem nagyon rendelkezünk adatokkal, egyetlen példát leszámítva: a szigeti Bothws Jánosét, akinek 1505-ben tett végrendelete szerencsésen fennmaradt ugyanis korunkig. ${ }^{405} \mathrm{~A}$ középkori testamentumok hagyományos felépítését követő, egyes szám első személyben, János által saját kezűleg írt végrendelet tanúi a szigeti Tamás literátus, Gazda Gergely és Máté sóvágóbíró, szigeti polgárok voltak. Javai közül egy földjét Bothws Kelemen feleségének, Mártának, egy másikat Bothws István és Imre nevü fiainak és feleségének hagyja, de haláluk után a föld a szigeti egyházra szálljon. Az akolon túl lévő földjét, akárcsak egy másikat feleségére, illetve annak halála után unokáira, az akolját István fiára, negyedik földjét Bálint nevű unokájára, telkét pedig feleségére hagyja. A Bothws rokonság tehát egy több ingatlannal is ren-

\footnotetext{
${ }^{403} \mathrm{~A}$ literátus/Deak megkülönböztető nevek viselői a 15. században (de talán még a 16. században is) még valószínűleg nem váltak öröklődő családnevekké, így megfelelően dokumentálják az írástudókat. Papp 1956.

${ }^{404} \mathrm{Az}$ ezt és emellett migráció- és ipartörténeti kérdéseket feldolgozó tanulmányom jelenleg túl van a lektoráláson, és két részben fog megjelenni, a Névtani Értesítő 2014. és 2015. évi számában.

${ }^{405}$ DL 84083. A testamentumot már Solymosi László is említette. Solymosi 1999. 218. Jelentőségét növeli, hogy csak roppant kevés részletes, mezővárosi lakoshoz köthető végrendelet maradt fenn a középkorból, országos szinten is. Lásd erre összefoglalóan Gulyás 2011.
} 
delkező, emellett állattenyésztéssel is foglalkozó, módosnak tűnő família volt.

Ami bizonyosan közös volt ezekben az imént felsorolt társadalmi csoportokban: valószínúleg nagy számban kapcsolódhattak be a sókereskedelembe és -szállításba, és ezzel további bevételekhez juthattak. Ez a sajátosság jól mutatja a máramarosi mezővárosok különleges helyzetét, eltérő lehetőségeit más jellegü oppidumokkal szemben.

Ha viszont nem a tulajdonviszonyok oldaláról közelítünk a kérdéshez, hanem jogi szemszögből, akkor a helyzet annyiban módosul, hogy az oppidumok lakossága - és az öt város ennek számított - jogi értelemben jobbágy volt, azaz földesura - még ha sokkal kedvezőbb királyi földesuraságról van is szó - volt. Ebbe a körbe a nemesség értelemszerüen nem tartozott bele. Az egyik legfontosabb választóvonal az „igazi városok” és mezővárosok között pedig éppen ez volt.

A mezővárosi polgárság tisztában volt ezzel, és magukat okleveleikben sokszor „polgárnak” (civis) nevezték, nevük elé pedig a korban kijáró providus, sőt néha a circumspectus jelzőt helyezték. Érdekes, hogy általában az idegen szemlélők is így nevezik őket. Ennek oka az volt, hogy a mezővárosok universitast vagy communitast, azaz közös kiváltságaik, bíráskodási és más szabadságaik révén jogi egységet alkottak, akárcsak az igazi városok. ${ }^{406} \mathrm{~A}$ mezővárosi polgárok státusa tehát kettős. Egyszerre polgárok, de ugyanakkor - jogi értelemben - jobbágyok is, polgárságuk csak a kiváltságolt településen belül értelmezhető. ${ }^{407}$

${ }^{406}$ Így nevezi őket Máramaros megye 1494-ben: „circumspecti cives et hospites oppidi Techew”. Már. Dipl. 605. Sőt, 1459-ben a királyi oklevél egyenesen „prudens”-nek tekinti őket, ami általában csak a királyi civitasok lakosságára volt használatos: "in personis fidelium nostrorum prudentium et circumspectorum civium ac universitatis oppidi nostri Szigeth". Már. Dipl. 422. Máskor azonban egyszerűen „lakos"-ként említik őket, mint ahogyan például I. Mátyás 1461. évi parancslevelében is szerepel: „per Michaelem Sthibor inhabitatorem oppidi nostri Zygeth”. Már. Dipl. 439. V. László oklevele 1453-ban ugyan "prudens"-nek nevezi őket, de mégis, csupán az öt „villa”-ban élő hospesekről és jobbágyokról beszél: „hospitum seu iobagionum Saxonum scilicet et Hungarorum in villis nostris... existentibus". DF 274893. Ugyanebben az évben egy másik oklevelében is ilyen formában jelennek meg a mezővárosok lakói: „fidelium nostrorum providorum iudicum iuratorum ceterorumque universorum et singulorum --- hospitum populorum et iobagionum nostrorum in opidis nostris Wysk, Zygeth, Hwzth, Techew et Hozywmezew vocatis commorantium". DF 275901. A mezővárosi terminológiahasználatra összefoglalóan lásd Ladányi 1992.

${ }^{407}$ 1500-ban egy birtokba iktatáson újra lehull a lepel. Az ott szomszédként szereplő técsői polgárokat a leleszi konvent nyersen fogalmazva egyszerűen csak a „Técsőn lakó királyi jobbágyoknak" nevezi: „in oppido Thechew commorante jobbagionibus prefati domini nostri regis". Már. Dipl. 633. 



\section{A KORONAVÁROSOKON INNEN ÉS TÚL: ÚRMEZŐ A KÖZÉPKORBAN}

Ha a máramarosi városfejlődésről beszélünk, akkor mindenképpen szólni kell Úrmezőről is, amely ugyan nem számított a koronavárosnak, de ennek ellenére - utolsóként, azaz hatodikként a megyében - a középkor végére mezővárosi rangot ért el. A település Visktől és Técsőtől is mindöszsze néhány kilométerre, a Tisza jobb partján helyezkedik el, ám a közeli fekvés ellenére sem került be a koronavárosok közé. Érthető okokból: a privilegizáláskor a falu még nem létezett, legalábbis nincs róla forrásunk, így abba még nem is vehették be a lakóit, a későbbiekben pedig magánföldesúri birtokba került, s ez így is maradt a középkor folyamán. Úrmező a román eredetü birtokosok ellenére magyar lakossággal bírt. ${ }^{408}$

Úrmező a mezővárosi fejlődés klasszikusnak tekinthető útját járta be, s szerves fejlődés eredményeként vált oppidummá. A település viszonylag későn jelenik meg a forrásokban, 1389-ben említik elsőként, amikor a leleszi konvent országbírói parancsra Drág székelyispán máramarosi javait meghatárolta. Ekkor possessio. ${ }^{409}$ Bár Csánki szerint csak 1409-ben került az Úrmezeiek birtokába, és Engel Pál is így rögzítette birtoktérképe adattárában, a már említett 1405. évi, a Talabor folyó elterelésével kapcsolatosan íródott oklevél alapján azt már valószínűleg 1395-ben is birtokolták a nevüket a településről szerző család tagjai. ${ }^{410} \mathrm{~A}$ família ezután is többször pe-

\footnotetext{
${ }^{408}$ Birtokosai, a vlah eredettel bíró Úrmezeiek a megye gyakran felbukkanó közszereplői voltak. Birtokaikra lásd Csánki I. 460. Úrmező azon kevés település közé tartozik, amelyet a birtokos család valószínűleg nem kenézségként, hanem már eleve nemesi jogon kaphatott. Bélay 1943. 39., 211.

${ }^{409}$ A határjárásban: „possessionis Urmezeu apellatae”. DL 7481. ZSO I. 917. sz; Már. Dipl. 93. Történetére általánosságban lásd: Csánki I. 453.

${ }^{410}$ Engel 2001. A folyó elterelése mellett az Úrmezeiek ellen különféle hatalmaskodásokat is elkövettek Drágék: "quomodo alias quondam magister Balk voyvoda Maramarosiensis ac Demetrius filius eiusdem --- armatis et potentiariis, cum integra potentia gentis eorum exercitualiter ad possessionem ipsorum irruendo ac --- ferendo, quendam fluvium Thalabor
} 
reskedett a Balk és Drág-féle rokonsággal. 1397-ben, amikor utóbbiak bejáratták Técső határait, Úrmezei Iván fia Demeter az Úrmezővel közös határ megállapítása okán ellentmondással élt. ${ }^{411}$ 1405-ben, az említett folyóeltereléssel kapcsolatos ügyben Zsigmond parancsára a leleszi konvent folytatott vizsgálatot, melynek eredményét és a további fejleményeket sajnos nem ismerjük. 1409. szeptember 22-én végül Zsigmond parancsot adott a leleszi konventnek, hogy iktassák be Úrmezei Szaniszló fiait, Miklóst és Szaniszlót, illetve István fia Miklóst és Dénest az őket jogszerüen megillető Úrmező birtokába. Az iktatás ugyanazon év november 22-én meg is történt. ${ }^{412}$ A birtoktestet 1415-től jelentősen sikerült kibővíteni, többek között Lipcse, Herincse, Berezna, Ökörmező, Kövesliget, Nyágova, Gánya, Felső-Apsa, Alsó-Róna, Bárdfalva, Kalinfalva és Balotafalva, Kaszó, Budfalva, Vincfalva, és Fejérfalva birtokokat is megszerezték, még ha ezek közül néhányat el is vesztettek a későbbiekben. ${ }^{413}$

A települést a 15. század nagy részében az Úrmezeiek birtokolták. Az 1490-es évekre azonban a családnak magva szakadt, a király pedig 1492 szeptemberében a Úrmezőt és más jószágokat (a veresmarti, herincsei, felsőapsai és karácsonyfalvai birtokokról illetve részbirtokokról van még szó) Bélteki Drágffy Bertalan ${ }^{414}$ erdélyi vajdának adományozta, amit azonban a Veresmarti László fia Tamás nevében megjelenő Szécsi Lukács tiltott. Úgy tűnik, hogy sikerrel, aminek egy éveken át húzódó per lett az eredménye. A király 1495. szeptember 9-i oklevelével Úrmezőt végül Csebi Pogány Péternek és rokonságának adta hü szolgálataikért cserébe, azonban Drágffy Bertalan bocskói tisztje, Thot Balázs ura nevében ellentmondott az adásvételnek. 1498. november 18-án az ügy folyományaként már arról értesülünk, hogy Drágffy Bertalan visszavonta ellentmondását. ${ }^{415}$

nuncupatum de recto, usitato suo meatu in novis fossatis recipiendo --- rursus et indirectos meatus fluctuare permisissent eandem possessionem in minima ipsius aquae exundatione --- decima instaret revolutio". Már. Dipl. 130.

411 "et cum ipsi eandem a parte possessionis Urmezew nuncupatae reambulare, metasque eiusdem erigere voluissent, tunc Demetrius filius Iwan de eadem Urmezew inibi personaliter adhaerendo, ipsos non a reambulatione, sed metarum erectione prohibuisset contradicendo". Már. Dipl. 118.

${ }^{412}$ Lelesz Stat. 184., 186. sz; Az adomány tárgya: „eiusdem possessionis eorum Urmezeu vocatae in comitatu Maramarosiensi existentis, ipsos omni iure concernentis". Már. Dipl. 157-158. Nem tudni, milyen alapon bírták az adománylevél előtt a birtokot, és milyen okból volt szükség a királyi megerősítésre, mivel az oklevél nem számol be róla. A család vlah származását figyelembe véve felvethető lenne, hogy esetleg kenézi jogú birtok nemesi jogúvá tételéről volt szó, azonban a famíliát már az 1405. évi idézett oklevél is nemesként aposztrofálja: „possessionem praedictorum nobilium Urmezew vocatam”. Már. Dipl. 131.

${ }^{413}$ ZSO V. 1061, 1334. sz; ZSO VII. 531. sz; Már. Dipl. 263-264.

${ }^{414}$ Jagelló-kori politikai szereplésére lásd Neumann 2012.

${ }^{415}$ DL 36398; Már. Dipl. 610-613; 622-623. 
A település tehát a Csebieké lett, akiknek a birtoklása 1516-ig tartott. Úrmező másik ismert részbirtokosa Thykoro-i Thykoroczky Máté királyi kamarás (cubicularius) volt. Ekkor Csebi Pogány Péter az Eufrozinával, a néhai Kisvárdai Aladár Péter lányával kötendő házassága költségeire és az asszonynak járó hitbérre és nászajándékához szükséges összeg előteremtésére 2000 arany forintért zálogba adta Úrmezőt, a hozzá tartozó possessiokkal együtt. Ez a forrásunk az, amely első alkalommal említi oppidumként a települést. ${ }^{416}$

Úrmező fejlettségét tekintve nem érte el a jelentősebb máramarosi mezővárosok, főleg Huszt vagy Sziget szintjét, de azért figyelemreméltó módon és Máramarosban egyedüliként középkori adattal is egyértelműen bizonyíthatóan országos vásártartási joggal rendelkezett. ${ }^{417}$

Az 1505. július 2-án II. Ulászló által kibocsátott privilégium a település földesurainak, Thykoro-i Thykoroczky Máté királyi kamarásnak és Csebi Pogány Zsigmondnak a kérésére, egyúttal az úrmezei lakosok hasznára (pro utilitate et augmento incolarum et inhabitatorum possessionis ipsorum) került kibocsátásra és évi négy sokadalmat engedélyezett. A vásárok Szent Ilona (május 22.), Szent László (június 27.), Szent Mihály arkangyal (szeptember 29.) és Vízkereszt (január 6.) ünnepein kerültek megrendezésre. Mindezek mellett még egy hétfői hetivásár tartásának joga is szerepel a kiváltságlevélben. ${ }^{418}$

Szintén lényeges momentum, hogy a település az Úrmezei család gyarapodó birtokainak uradalmi központja volt, ami abból is látszik, hogy a Jagelló-korban officiálissal rendelkezett, így valószínúleg bizonyos központi funkciót töltött be a birtoktesten élők számára. ${ }^{419}$ Mezővárosi tanácsáról, oklevéladásáról ugyanakkor, sajnálatos módon nincs adatunk.

${ }^{416}$ Máté 1505-ből adatolható részbirtoklására lásd DF 275935. Az 1516. évi oklevél 18. századi, kivonatos és meglehetősen zavaros szövegezésű másolatban maradt fenn. A zálogba vevő személyéről például nem történik említés, a levéltári regeszta sem beszél róla. A birtoktest részeként felsorolt possessiók: „Totale oppidum suum Urmezü nuncupatum cum totalibus possessionibus Bellezna, Keressziget, Nyagova, Felsö Bocsko, Felsö Viso, Also Viso, Dragomerfalva, Fejerethaza (!), Ekermezö et Repine vocatis in comitatu Marmaros (!) adiacentes, ad idem oppidum Urmezü pertinentes". DL 71395. Ekkor már a szöveg alapján csak a Csebiek bírták Úrmezőt.

${ }^{417}$ Csánki I. 453. Csánki hivatkozása ugyan pontatlan, de a vásárkiváltságot magában foglaló oklevél jelenleg is meg van: DF 275935. A jelenkori szakirodalom nem ismer sokadalmat Úrmezőn, sőt, heti piacról sem tud. Weisz 2012. 152.

${ }^{418}$ DF 275935.

${ }^{419}$ DL 21380. 



\section{EPILÓGUS HELYETT: A VÁROSFEJLESZTŐ TÉNYEZŐK (HIÁNYA?)}

Hogyan lehetne mérleget vonni és meghatározni a koronavárosok által elért fejlődés szintjét és sajátosságait? Amióta a mezővárosok a kutatás látószögébe kerültek, leginkább jogi (kiváltságok és terminológia) és gazdaságtörténeti (árutermelés, vásárjog, uradalmi központ-szerep) szempontok alapján próbálták beilleszteni őket a középkori városfejlődésbe és a Magyar Királyság gazdasági rendszerébe. ${ }^{420}$ Újabban, Kubinyi András kutatásainak eredményeképpen megjelent egy funkcionális nézőpont is. Eszerint egy települést az tesz fontossá, ha minél több nem hétköznapi („,centrális" vagy „,központi”) funkciót lát el, amelynek következtében gazdasági és társadalmi hatást és vonzóerőt tud gyakorolni a szűkebb vagy tágabb környékére is. ${ }^{421}$

\footnotetext{
${ }^{420}$ A vonatkozó szakirodalom nagy részét már hivatkoztam. A historiográfiai összefoglalásra lásd: Gulyás 2009.

${ }^{421}$ Kubinyi András az úgynevezett „,centralitási pontrendszer” kidolgozása során tíz városias funkciót, illetve városokra jellemző tulajdonságot vett figyelembe. A kategóriákat egytől hatig pontozva ebben a rendszerben így összesen 60 pontot szerezhet egy település. Ezek a következők voltak: I. Uradalmi központi- és rezidencia-szerep; II. Bíráskodási-központi és hiteleshelyi funkció; III. Pénzügyigazgatási központi funkció; IV. Egyházi igazgatásban játszott szerep; V. Egyházi intézmények száma a településen; VI. A külföldi egyetemekre (Bécsbe és Krakkóba) beiratkozók száma 1440 és 1514 között; VII. Kézműves- és kereskedőcéhek száma; VIII. Úthálózati csomópont-szerep; IX. Vásártartás, azaz a heti- és éves vásárok száma a településen; X. A település jogi helyzete. Kubinyi 2000. 13-14. A kapott pontszámok alapján a településeket Kubinyi hét, fejlettségük mértékét kifejező csoportba osztotta. A funkcionálisan valódi város szerepet betöltő települések szerinte az első négy kategóriában helyezkednek el, azaz ezeket lehet városias településnek tekinteni a középkor végi Magyarországon. A pontrendszer több évtizedes kutatás eredményeképpen formálódott ki. A kialakítás folyamatára: Lakatos 2013. 18-24. A centralitási pontrendszert azóta is többen alkalmazzák a magyar városkutatásban. Gulyás 2013. 319., 5. jegyzet.
} 
Lássunk mi is néhány ilyen szempontot, az eddigieket kiegészítve. Először is, a városi fejlődést elősegítő, centralitási tényező volt például Sziget szempontjából, hogy a megyegyülés helyszínéül szolgált, hiszen ez növelte a piaci keresletet és frekventált hellyé tette a települést. ${ }^{422}$

A másik fontos, ám ellenkező előjelű megjegyeznivaló: Máramaros területén, mint láthattuk, csak Úrmezőn volt a középkorban egyértelműen bizonyítható módon éves vásár. Ha logikusnak tünik is az a felvetés, hogy az újkorban működő országos vásárok talán már a középkorban is müködtek, különös, hogy holott viszonylag nagy számú, több száz darabnyi forrás áll rendelkezésre a mezővárosok és környékük múltjának vizsgálatához, nincs adatunk az öt mezőváros középkori sokadalomtartási jogáról. ${ }^{423}$

Ez a kijelentés nem érdektelen, ha tudjuk, hogy például csak az ÉszakAlföldön több tucatnyi sokadalomtartási joggal rendelkező falu, és még több, nem is egy, hanem évenként $2-4$ vagy még több alkalommal vásárt rendező mezőváros állt. Ráadásul a heti piac csak a városfejlődés korai szakaszában tudott igazán sokat lendíteni a település helyzetén, későbbi komolyabb fejlődéséhez elengedhetetlen lett volna a vásártartás joga. ${ }^{424} \mathrm{Ez}$ a tény, pontosabban annak hiánya tehát több mint elgondolkodtató, de természetesen az sincs kizárva, hogy valójában volt sokadalomtartási joguk, csak az ezt rögzítő források eltüntek a századok során.

Más is hiányzott azonban. Nem volt például olyan mezőgazdasági termék sem az amúgy is rossz minőségű termőfölddel rendelkező Máramarosban, amely egy ezzel kereskedő, izmos polgári réteget létrehozhatott volna. Nyilván volt már a középkorban is jelentősebb állattenyésztés a mezővárosok határaiban, ${ }^{425}$ és a só is fontos árucikként szolgált, de hiányos forrásaink miatt nincs olyan középkori adatunk, amely bizonyítaná ennek ellenkezőjét.

${ }^{422}$ 1383-ben van rá az első adat, de később, a 15. században továbbra is Sziget a központ, ahogyan erről már volt szó. Bélay 1943. 26; Csukovits 1997. 382.

${ }^{423}$ A középkori vásárnapok szempontjából főleg a helyi egyházak védőszentjeivel egybeeső újkori vásárnapok gyanúsak. Ilyen a huszti Szent Erzsébet (november 19.)-napi és a técsői Szent Péter és Pál ünnepén (június 29.) az újkorban rendezett országos vásár. A vásárok napjait az újkorban összeírták. (Österreichisches Staatsarchiv, Hofkammerarchiv, Hoffinanz, ungarische Reihe 1756. nov. 9. melléklet = r. Nr. 867b. fol. 136r-v). Glück László szíves közlése.

${ }^{424}$ Egyébként meg a heti piacra is csak a privilégium szolgál az egyedüli információval, ami öt mezőváros esetében szintén igen furcsa. Weisz 2012. 152.

${ }^{425}$ Erre utal például a szigeti Bothws János ismertetett végrendeletében szereplő „stabulum vulgo akool” kifejezés is, azaz a polgárok egy része bizonyosan tenyésztett juhot, kecskét, lovat vagy marhát. DL 84083. 
A természetföldrajzi viszonyok meglehetősen mostohák voltak. Máramaros területét a középkor folyamán nagy részben fenyvesek borították, amelyek a viszonylag alacsonyabb hegyvidékekre is kiterjedtek. Az erdőségeket a havasokon néhol hegyi legelők váltották, amely lehetőséget teremtett az állattartásra is. ${ }^{426}$ Emiatt a vlah betelepedésig nem volt jelentősebb népességkoncentráció Máramarosban, de valójában azután sem.

Érdekes adat árulkodik erről a helyzetről a 16. század végéről. Az 1598. évi dikális összeírás, amely házanként veszi figyelembe az adózókat, országos szinten, de a szabad királyi városok nélkül 6570 település 165069 háztartásáról számolt be. Így összességében az egy településre megyénként jutó átlagos házszám bő 25 volt, míg Máramarosban volt a legalacsonyabb, mindössze 9, szemben például a csúcstartó Moson megye átlagosan 62 házas értékével. ${ }^{427} \mathrm{Ez}$ alapján tehát a máramarosi falvak a mostoha természet- és gazdaságföldrajzi viszonyok eredményeként még a kora újkorban is meglehetősen kis népességszámmal rendelkeztek, s ez a helyzet bizonyosan már a középkorban is hasonlóképpen nézett ki. Igaz, hogy a fenti adat nem a mezővárosokra, hanem a környező falutelepülésekre vonatkozik, de véleményem szerint így is megfelelően utal a falusi népességgel megegyező feltételek között élő máramarosi mezővárosok lakosságának agrártevékenységgel kapcsolatosan megjelenő gazdasági korlátaira.

A Máramarosban megtelepedő népesség a hegyvidék vizek által szabdalt völgyeiben talált lakóhelyet magának, ahol azonban sem a termőföld minősége, sem pedig mennyisége nem volt megfelelő. A kiváltságlevélben szereplő, már említett és a hazai gyakorlatban amúgy is ritka megjegyzés a rossz termésü évekre jól mutatja ezt a helyzetet. ${ }^{428}$

Erre utalhat még az az 1548. évi szabály, ami szerint élelmiszert (nyilván, alapvetően gabonát) csak úgy lehetett kivinni Máramarosból, ha előtte legalább az öt városból háromnak a vásárán, vagy közvetlenül a sókamarának felkínálták azt eladásra. Azaz a kamarát elővásárlási jog illette meg ebből a szüken rendelkezésre álló fontos árucikkből. ${ }^{429}$

A természetföldrajzi jellegzetességeknek köszönhetően így nem folyt például Máramarosban szőlőtermelés, ezért a bérmunka sem alakulhatott ki olyan mértékben, mint az történt az ország más területein. Szőlőterme-

${ }^{426}$ A természetföldrajzi viszonyokra összefoglalóan: Györffy IV. 111-112. A fenyvesekre nézve az okleveleink határjárásaiban is vannak források. „arbores iuniperi quae vulgo dicuntur Fenyeu” Már. Dipl. 133; „Fenyesheg” Már. Dipl. 391; „Fenywspathaka” Már. Dipl. 509. stb.

${ }^{427}$ Zimányi 1980. 512-513.

${ }^{428}$ Lásd a kiváltságlevélben: „quia ipsa terra Maramurusiensis multum sterilis”. CDH VIII/3. 353. Később is sokszor hangoztatják ezt a források. Még a 17. század elején is előfordult, hogy Máramaros a rossz termés miatt gabonabehozatalra szorult. Glück 2013. 184.

${ }^{429}$ Glück 2013. 96. A forrás latin szövegét lásd uo. 271. jegyzet. 
lés - kérdéses minőségben - talán Huszton folyhatott, de inkább az lehetett a jellemző, hogy a polgárság Szőllősön vagy környékén próbált magának szőlőbirtokot szerezni. ${ }^{430}$

Volt azonban ehelyett egy, a sókamara igazgatásában és a só kereskedelmében is bizonyos mértékben érdekelt, részben nemesi attitűddel rendelkező mezővárosi vezetőréteg, amely a polgári gondolkodásmód egyes elemeit már nem tette magáévá. Máshogyan ugyanis nem magyarázható, hogy a koronavárosok lakossága a középkor végén nem küldött értékelhetô számban a kor két, közelben fekvő és népszerű egyetemére diákot. Ez az 1440 és 1514 közötti bécsi és krakkói egyetemi anyakönyvek anyaga alapján állítható, holott a korban már nagy számban tanultak mezővárosi fiatalok ezekben az intézményekben. ${ }^{431}$

Szintén erre a mentalitásra utalhat még egy adat. Az ispotályos rend római ispotályának volt egy népszerű intézménye a korban: a SzentlélekTársulat. Ebbe Európából - Magyarországról is - igen nagy számban léptek be a hívek. Igaz, a belépés nem volt egyszerü, vagy személyesen, vagy megbízott útján lehetett ezt megtenni, Rómában. De úgy látszik, ez mégsem okozott igazán nagy gondot, mert Magyarországról is ismerünk 3833 olyan személyt, nemest és papot, polgárt és jobbágyot, aki ezt megtette. A jelentkezők a Kárpát-medence minden vidékéről származtak, összesen 505 településről. Ennek függvényében - főleg azt tekintve, hogy mint láttuk, voltak kifejezetten jómódú városlakók is Máramarosban - meglepő, hogy az öt mezővárost egyetlen polgár sem képviselte ezek között. ${ }^{432}$

A városfejlődés szintjét a koldulórendi kolostorok, illetve ispotályok megléte is megfelelően jellemzi. A francia középkorász, Jacques Le Goff frappáns felvetése szerint, mivel a koldulórendek a polgárság adományaiból élnek, és ott telepednek meg, ahol ilyenre számíthatnak, az egyes településeken való jelenlétük, és az ott működő kolostoraik száma egyértelműen utal az adott helység fejlettségére. A vizsgálati módszert Fügedi Erik alkalmazta elsőként Magyarországon, eredményesen. ${ }^{433}$

Erről az oldalról nézve sokatmondó adat a máramarosi városfejlődéssel kapcsolatban, hogy az urbanizációt szem előtt tartó koldulórendek is elkerülték a vidéket. A Tisza felső folyásán a legközelebbi - ferences - in-

\footnotetext{
${ }^{430}$ Szőllős város 1515. január 1-ji oklevelében jelenik meg a már említett és az ott több szőlővel is rendelkező szőlőbirtokos „,egregius Nicolaus Barylowych de Borycha in oppido Hwzth commorans". DL 84623. A máramarosi mezővárosokban nincs adat szőlőbirtokosokra. Az ismert ingatlanok: Hosszúmezőn rét (DF 247927); Huszton malmok, malomrészek, szántók és rétek (DL70984, DF 285466) feküdtek.

${ }^{431}$ Kubinyi 1971a. 74-76. Kubinyi csak a 8 diáknál több egyetemistával rendelkező településeket vette be a listába.

${ }^{432}$ Csukovits 2000. 228-234.

${ }^{433}$ Fügedi 1972. Kubinyi András szerint ugyanilyen módon utal a város fejlettségére, hogy van-e ispotály a területén, avagy nincs. Kubinyi 2004.
} 
tézmény Szőllősön telepedett meg, de az öt város egyikében sincs ilyen, holott nem egyszer megfigyelhető, hogy a koldulórendek még jogi értelemben vett falvakban is megjelentek. ${ }^{434}$

Emellett pedig a területet a fóként a jobbágyság adományaira (leggyakrabban szőlőkre) építő pálosok is ,elkerülték" ${ }^{435}$ legalábbis az itt álló öt mezőváros (illetve a hatodik, Úrmező) közelében mindössze egyetlen kolostoruk volt. Ez a Tisza bal partján, nagyjából Bedőházával szemben elhelyezkedő Remete (ma a román-ukrán határon álló Remeți), amely 1363-ban létesült I. Lajos alapításaként. ${ }^{436}$ A Szűz Mária patrocíniumát viselő kolostor a legközelebbi mezővárostól, Hosszúmezőtől is minimum 10 kilométerre feküdt, távolsága Visktől pedig legalább kétszer ekkora volt. A közelebb, alig pár kilométerre lévő Técsőtől az intézményt a Tisza választotta el.

Habár a pálosok a legtöbb esetben nem településeken jelentek meg, hanem azok szomszédságában, azért - már csak a gyakori kegyes adományok miatt is - sokszor megfigyelhető, hogy viszonylag szoros kapcsolatuk alakult ki a környékbeli mezővárosokkal és lakosaikkal, mint az példának okáért Abaújban és Zemplénben is jól adatolható, ahol az oppidumok mindennapi életének szerves részét képezték. Máramarosban azonban úgy látszik, szó sincs ilyenről. Ez természetesen nem jelenti azt, hogy ne kaptak volna adományokat, azonban jelzésértékű, hogy ezekből a mezővárosok polgársága jóval kevésbé vette csak ki a részét, mint az máshol megfigyelhető. ${ }^{437} \mathrm{~A}$ már említett körtvélyesi bazilita intézményen

${ }^{434}$ A köztudatban meggyökerezett, hogy Huszton a bencések és a ferencesek is megtelepedtek, valamint, hogy ugyanott volt egy apácazárda is, illetve, hogy Técsőn és Huszton is állt pálos kolostor. Wenzel 1857. 81. és Czébely 2002. 34. stb. Okleveles nyomát azonban nem találni a dolognak. A kolostorokra lásd F. Romhányi 2000. részletes adattárát, ahol szintén nem szerepelnek ezek a feltételezett intézmények.

${ }^{435}$ A középkor végén messze a pálosok kapták a legtöbb kegyes adományt a mezővárosokban vagy környékükön, a polgárság körében pedig egyértelműen a pálosok jelentették az elsődleges, adománnyal ellátandó intézménytípust. Gulyás 2011. 197.

${ }^{436}$ Wenzel 1857. 33. Történetét röviden összefoglalja: Kovács 1987. 123; Guzsik 2003. 137. Remete a beregi pálos vikárius alá tartozott. Hervay 1984. 168. Az intézmény nem kolostor, hanem „remeteség” módjára épült. F. Romhányi 2000. 54.

${ }^{437}$ A remetei pálosok egyedüli mezővárosiként 1406-ban a huszti Kelemen deáktól kaptak egy fél malmot, ezen-kívül azonban csak nemesek és papok adományaira maradt fenn adatunk (1481-ben a máramarosi ispántól egy malomrészt, 1492-ben a verőcei plébánostól egy szőlőt, 1524-ben pedig Keszi Balázsnak a beregi Nagymuzsajon fekvő birtokát kapták adományként). Kovács 1987. 123. Az intézmény relatív szegénysége az oka annak is, hogy királyaink, ahogyan tudták, rendszeresen támogatni próbálták a szerzeteseket. 1363-ban I. Lajos egy malmot adományozott nekik, 1389-ben Mária királynő előírta, hogy a técsői polgárok csak a pálosok malmában őrölhetnek, 1493-ban Beatrix királynő pedig a máramarosi sóbányák jövedelméből évi 50 forintot utalt ki a részükre. Mindenesetre a 16. század közepén adományba kapott 3 malmuk értéke (pontosabban közbecsüje) így is összesen 20 márkányit tett ki. F. Romhányi 2007. 329, 343. 
és Remetén kívül más szerzetesközösség pedig nem hozott létre kolostort Máramaros megyében. És nem is véletlenül.

Az elmondottak alapján nem meglepő, hogy Kubinyi András centralitási pontrendszerében sem értek el a koronavárosok igazán magas pontszámot. Huszt (16 pont) a negyedik, közepes városfunkciót ellátó mezővárosok csoportjába - annak legaljára - került ugyan, de Sziget (13 pont) már csak az ötödik, részleges városfunkciójú mezővárosok közé, maradék oppidumaink pedig a hatodik csoport tagja lettek csupán. ${ }^{438}$ Kubinyi a városi funkciót betöltő településeket a centralitási pontrendszer első négy szintjén elhelyezkedő központi helyekben látta, azaz, amennyiben igaza van, csak Huszt nevezhető jelentősebb központi helynek a térségből.

A fentieket összefoglalva, a máramarosi mezővárosi fejlődés véleményem szerint fél lábon állt: felívelése legnagyobb részben a sóbányászatnak köszönhető, amely az oppidumok ilyen, országosan egyedülálló típusát úgy is képes volt létrehozni, hogy a városfejlődés máshol megszokott jelenségei, illetve alapfeltételei nem vagy csak részben voltak jelen a területen. Ez még akkor is igaznak tünik, ha a mezővárosok nem minden társadalmi rétege kötődött egzisztenciális szempontból szorosan a sóbányákhoz. A különféle agrárius és iparos-kereskedő rétegek itt is megjelentek, de nem érzékelhető, hogy a mezővárosok gazdasági fejlődésének ez a tevékenységük igazi lökést tudott volna adni.

Az, hogy a mezővárosok kiváltságaikat kollektív módon kapták, egyértelműen mutatja ezt a felemás helyzetet. A fél lábon állás eredménye a Sziget kivételével megfigyelhető viszonylag gyenge iparfejlődés, a kereskedelmi életen belül a sókereskedelem nyomasztó fölénye és a lakosság későbbi elnemesedése, mely főleg szintén Szigeten figyelhető meg a 16. század végétől. Meglátásom szerint a kiváltságlevelek is elsősorban a mezővárosok sótermelésben és -kereskedelemben játszott fontos szerepének és a királyi sóbevételek stratégiai jelentőségének voltak köszönhetők.

A máramarosi mezővárosiak számára azonban ez a helyzet ennek ellenére is kedvező volt: kiváltságaik lehettek volna ugyan széles körübbek is, de a sókamara és a bányák állandó jövedelemforrást, az elidegeníthetetlen királyi lét pedig a korban kifejezetten ritka hosszútávú kiszámíthatóságot és biztonságot jelentett a számukra. Amíg a királyi hatalom viszonylag szilárd volt - és ez az Anjou-kortól kezdve kisebb megingásokkal végig megfigyelhető -, addig arra törekedett, hogy a területet szoros fennhatósága alatt tartsa, és ez a törekvés nagyrészt sikeres is volt. Ez a helyzet egy egészen egyedi fejlődési pályát eredményezett tehát, ami remekül bizonyítja, hogy a mezővárosok között mennyi eltérő helyzetü és lehetőségü település van, és a középkori mezővárosi fejlődés sokkal inkább ezen a sokoldalúságon és spontaneitáson alapul, mint az előre leírható törvényszerüségeken.

\footnotetext{
${ }^{438}$ Kubinyi 2000. 71., 88., 91., 93., 99.
} 


\section{FÜGGELÉKEK}

\section{A máramarosi mezővárosokra alkalmazott terminológiahasználat ${ }^{439}$}

\begin{tabular}{|c|c|c|c|c|}
\hline Dátum & Település & Megnevezés & Oklevél kiadója & Forrás \\
\hline 1281 & Visk & villa et terra & IV. László & CDH V/3. 88. \\
\hline 1291 & Visk & terra & III. András & CDH VII/2. 147. \\
\hline 1291 & Visk & $\begin{array}{l}\text { villa seu } \\
\text { possessio }\end{array}$ & III. András & HO VIII. 445. \\
\hline 1292 & Visk & terra & váradi káptalan & CDH VII/2. 170. \\
\hline 1300 & Visk & possessio & III. András & CDH VI/2. 253. \\
\hline 1329 & $\begin{array}{l}\text { Hosszúmező, } \\
\text { Huszt, Técső, Visk }\end{array}$ & villa & Károly Róbert & $\begin{array}{l}\text { CDH VIII/3. } \\
353 .\end{array}$ \\
\hline 1336 & Técső & civitas & egri káptalan & Már. Dipl. 14. \\
\hline 1352 & $\begin{array}{l}\text { Hosszúmező, } \\
\text { Huszt, Sziget, } \\
\text { Técső, Visk }\end{array}$ & villa & I. Lajos & DL 2539. \\
\hline 1365 & $\begin{array}{l}\text { Hosszúmező, } \\
\text { Huszt, Sziget, } \\
\text { Técső, Visk }\end{array}$ & villa & I. Lajos & DL 2539. \\
\hline 1389 & Visk & villa & országbíró & Már. Dipl. 90. \\
\hline 1389 & Huszt & villa & országbíró & Már. Dipl. 90. \\
\hline 1389 & Hosszúmező & possessio & országbíró & Már. Dipl. 92. \\
\hline
\end{tabular}

${ }^{439}$ Ha a települések oszlopában többet is felsorolok, akkor az oklevél név szerint említve vagy anélkül, de kollektíven nevezi meg őket. Ha csak egy településnév szerepel, akkor a terminológia csak arra az egyre vonatkozik. Ha a megnevezés kapcsán két terminustípus is szerepel, és közöttük vessző van, akkor az oklevélszövegben két különböző helyen máshogy nevezik a mezóvárost. 


\begin{tabular}{|c|c|c|c|c|}
\hline 1389 & Técső $^{440}$ & possessio & országbíró & Már. Dipl. 93. \\
\hline 1397 & Técső & possessio & leleszi konvent & Már. Dipl. 117. \\
\hline 1398 & Visk & terra & váradi káptalan & CDH X/2. 593. \\
\hline 1404 & $\begin{array}{l}\text { Hosszúmező, } \\
\text { Huszt, Sziget, } \\
\text { Técső, Visk }\end{array}$ & villa & Lux. Zsigmond & DL 2539. \\
\hline 1406 & $\begin{array}{l}\text { Hosszúmező, } \\
\text { Sziget }\end{array}$ & possessio & Lux. Zsigmond & Már. Dipl. 138. \\
\hline 1406 & $\begin{array}{l}\text { Hosszúmező, } \\
\text { Huszt, Sziget, } \\
\text { Técső, Visk }\end{array}$ & oppidum & Lux. Zsigmond & Már. Dipl. 144. \\
\hline 1407 & $\begin{array}{l}\text { Hosszúmező, } \\
\text { Huszt, Sziget, } \\
\text { Técső, Visk }\end{array}$ & oppidum & Lux. Zsigmond & Már. Dipl. 148. \\
\hline 1408 & Sziget & civitas & $\begin{array}{l}\text { máramarosi } \\
\text { ispán }\end{array}$ & Már. Dipl. 154. \\
\hline 1408 & Huszt & $\begin{array}{l}\text { civitas seu } \\
\text { oppidum }\end{array}$ & Lux. Zsigmond & Már. Dipl. 156. \\
\hline $1411 ?$ & Sziget & oppidum & leleszi konvent? & Már. Dipl. 179. ${ }^{441}$ \\
\hline 1418 & Sziget & possessio & leleszi konvent & Már. Dipl. 220. \\
\hline 1435 & $\begin{array}{l}\text { Hosszúmező, } \\
\text { Huszt, Sziget, } \\
\text { Técső, Visk }\end{array}$ & villa & Lux. Zsigmond & DL 2539. \\
\hline 1435 & Técső & oppidum & Lux. Zsigmond & Már. Dipl. 300. \\
\hline 1436 & Técső & oppidum & Lux. Zsigmond & Már. Dipl. 303. \\
\hline 1442 & Sziget & oppidum & országbíró & Már. Dipl. 320. \\
\hline 1443 & Huszt & oppidum & I. Ulászló & DF 247893. \\
\hline 1453 & Sziget & oppidum & $\begin{array}{l}\text { Máramaros } \\
\text { megye }\end{array}$ & Már. Dipl. 363. \\
\hline 1453 & $\begin{array}{l}\text { Hosszúmező, } \\
\text { Huszt, Sziget, } \\
\text { Técső, Visk }\end{array}$ & civitas & $\begin{array}{l}\text { Hunyadi János } \\
\text { országos főka- } \\
\text { pitány }\end{array}$ & Már. Dipl. 367. \\
\hline 1453 & $\begin{array}{l}\text { Hosszúmező, } \\
\text { Huszt, Sziget, } \\
\text { Técső, Visk }\end{array}$ & villa & V. László & DF 274893. \\
\hline 1453 & $\begin{array}{l}\text { Hosszúmező, } \\
\text { Huszt, Sziget, } \\
\text { Técső, Visk }\end{array}$ & oppidum & V. László & DF 275901. \\
\hline
\end{tabular}

\footnotetext{
${ }^{440}$ Nagy-Técső („Nog-Techeu”).

${ }^{441} \mathrm{Az}$ érintett oklevélszöveget egy pontos dátumot nélkülöző, a kiadót sem említő leleszi fogalmazványból írta át Mihályi János.
} 


\begin{tabular}{|c|c|c|c|c|}
\hline 1456 & Hosszúmező & civitas & leleszi konvent & $\begin{array}{l}\text { Már. Dipl. 376., } \\
379 .\end{array}$ \\
\hline 1456 & Sziget & civitas & leleszi konvent & Már. Dipl. 378. \\
\hline 1456 & $\begin{array}{l}\text { Huszt, Técső, Szi- } \\
\text { get, Visk }\end{array}$ & oppidum & V. László & DF 247899. \\
\hline 1456 & Hosszúmező & oppidum & V. László & DF 247899. \\
\hline 1456 & Técső & oppidum & V. László & DF 247899. \\
\hline 1457 & Hosszúmező & oppidum & V. László & Már. Dipl. 395. \\
\hline 1457 & Sziget & oppidum & $\begin{array}{l}\text { Máramaros } \\
\text { megye }\end{array}$ & $\begin{array}{l}\text { Már. Dipl. } \\
\text { 402-403. }\end{array}$ \\
\hline 1457 & $\begin{array}{l}\text { Hosszúmező, } \\
\text { Huszt, Sziget, } \\
\text { Técső, Visk }\end{array}$ & oppidum $^{442}$ & $\begin{array}{l}\text { Máramaros } \\
\text { megye }\end{array}$ & Már. Dipl. 403. \\
\hline 1457 & Sziget & civitas & Sziget város & DF 247904. \\
\hline 1457 & Hosszúmező & oppidum & Sziget város & DF 247904. \\
\hline 1459 & Sziget, Técső & oppidum & I. Mátyás & $\begin{array}{l}\text { Már. Dipl. } \\
\text { 430-431. }\end{array}$ \\
\hline 1459 & $\begin{array}{l}\text { Huszt, Técső, Szi- } \\
\text { get, Visk }\end{array}$ & oppidum & I. Mátyás & DF 247907. \\
\hline 1459 & Hosszúmező & oppidum & I. Mátyás & DF 247907. \\
\hline 1459 & Técső & oppidum & I. Mátyás & DF 247907. \\
\hline 1461 & Sziget & civitas & Sziget város & Már. Dipl. 435. \\
\hline 1461 & Sziget & oppidum & I. Mátyás & $\begin{array}{l}\text { Már. Dipl. 437., } \\
439 .\end{array}$ \\
\hline 1462 & Sziget & oppidum & I. Mátyás & $\begin{array}{l}\text { Már. Dipl. 442., } \\
445 .\end{array}$ \\
\hline 1468 & Sziget & oppidum & váradi káptalan & Már. Dipl. 487. \\
\hline 1472 & $\begin{array}{l}\text { Hosszúmező, } \\
\text { Huszt, Sziget, } \\
\text { Técső, Visk }\end{array}$ & oppidum & I. Mátyás & Már. Dipl. 516. \\
\hline 1476 & Visk & oppidum & leleszi konvent & Már. Dipl. 533. \\
\hline 1479 & Sziget & oppidum & országbíró & Már. Dipl. 539. \\
\hline 1479 & $\begin{array}{l}\text { Hosszúmező, } \\
\text { Huszt, Sziget, } \\
\text { Técső, Visk }\end{array}$ & oppidum & I. Mátyás & DF 247924. \\
\hline 1480 & Huszt & civitas & Huszt város & DF 285466. \\
\hline 1481 & Visk & oppidum & I. Mátyás & DL 24849. \\
\hline 1482 & Huszt & oppidum & I. Mátyás & Teleki II. 155. \\
\hline 1482 & Huszt & oppidum & I. Mátyás & DF 247918. \\
\hline
\end{tabular}

\footnotetext{
${ }^{442}$ Egészen pontosan: „,szabad oppidum” („,et iuratis civibus liberorum oppidorum in dicto Maramarosio existentium").
} 


\begin{tabular}{|c|c|c|c|c|}
\hline 1487 & Huszt & oppidum & $\begin{array}{l}\text { Ilosvai Miklós } \\
\text { magán }\end{array}$ & Már. Dipl. 584. \\
\hline 1489 & Huszt & oppidum & leleszi konvent & Már. Dipl. 598. \\
\hline 1491 & Sziget & $\begin{array}{l}\text { oppidum, } \\
\text { civitas }\end{array}$ & Beatrix királynő & DL 83957. \\
\hline 1492 & Huszt & oppidum & Beatrix királynő & $\begin{array}{l}\text { Aragóniai } \\
\text { Beatrix 233., DL } \\
19819 .\end{array}$ \\
\hline 1494 & Técső & oppidum & $\begin{array}{l}\text { Máramaros } \\
\text { megye }\end{array}$ & Már. Dipl. 605. \\
\hline 1495 & $\begin{array}{l}\text { Hosszúmező, } \\
\text { Huszt, Sziget, } \\
\text { Técső, Visk }\end{array}$ & civitas & Beatrix királynő & DF 275910. \\
\hline 1498 & $\begin{array}{l}\text { Huszt, Sziget, } \\
\text { Técső }\end{array}$ & oppidum & II. Ulászló & Már. Dipl. 617. \\
\hline 1500 & Sziget & oppidum & $\begin{array}{l}\text { Máramaros } \\
\text { megye }\end{array}$ & Már. Dipl. 630. \\
\hline 1500 & Técső & oppidum & II. Ulászló & Már. Dipl. 633. \\
\hline 1503 & Visk & oppidum & Anna királynő & DL 24849. \\
\hline 1504 & $\begin{array}{l}\text { Hosszúmező, } \\
\text { Huszt, Sziget, } \\
\text { Técső, Visk }\end{array}$ & oppidum & Anna királynő & DL 22477. \\
\hline 1506 & $\begin{array}{l}\text { Hosszúmező, } \\
\text { Huszt, Sziget, } \\
\text { Técső, Visk } \\
\end{array}$ & oppidum & II. Ulászló & DF 274897. \\
\hline 1509 & Huszt & oppidum & $\begin{array}{l}\text { Butkai László } \\
\text { alispán és sóka- } \\
\text { marás }\end{array}$ & $\begin{array}{l}\text { Teleki gyömrői } \\
\text { 461. sz. (202.) }\end{array}$ \\
\hline 1513 & Técső & oppidum & II. Ulászló & DL 71133. \\
\hline 1514 & $\begin{array}{l}\text { Huszt, Hosszúme- } \\
\text { ző, Técső }\end{array}$ & oppidum & $\begin{array}{l}\text { máramarosi } \\
\text { kapitány }\end{array}$ & DL 62999. \\
\hline 1515 & Sziget & oppidum & II. Ulászló & DF 212557. \\
\hline 1518 & $\begin{array}{l}\text { Hosszúmező, } \\
\text { Huszt, Sziget, } \\
\text { Técső, Visk }\end{array}$ & oppidum & II. Lajos & DL 86752. \\
\hline 1519 & Sziget & oppidum & II. Lajos & DF 212556. \\
\hline 1521 & Huszt & oppidum & huszti várnagy & DL 47398. \\
\hline 1523 & Huszt & oppidum & Mária királynő & DF 247947. \\
\hline 1524 & Huszt & oppidum & Ugocsa megye & $\begin{array}{l}\text { C. Tóth } 2006 . \\
146 . \text { sz. }\end{array}$ \\
\hline 1526 & $\begin{array}{l}\text { Hosszúmező, Szi- } \\
\text { get, Técső, Visk }\end{array}$ & oppidum & Mária királynő & $\begin{array}{l}\text { Teleki gyömrői } \\
\text { 532. sz. }\end{array}$ \\
\hline
\end{tabular}




\section{Az ismert középkori máramarosi polgárok listája és legfontosabb adataik ${ }^{443}$}

\subsection{Hosszúmező}

\begin{tabular}{|l|l|l|l|l|l|l|}
\hline \multicolumn{1}{|c|}{ Név } & Évszám & $\begin{array}{l}\text { Tanács- } \\
\text { tagság }\end{array}$ & Birtokok & $\begin{array}{c}\text { Nemesi } \\
\text { cím }\end{array}$ & $\begin{array}{c}\text { Foglal- } \\
\text { kozás }\end{array}$ & Forrás \\
\hline $\begin{array}{l}\text { Anthonius } \\
\text { Egidii }\end{array}$ & 1442 & & $\begin{array}{l}\text { birtok } \\
\text { Hosszúmező } \\
\text { mellett }\end{array}$ & & $\begin{array}{l}\text { Már. Dipl. } \\
321 .\end{array}$ \\
\hline $\begin{array}{l}\text { Nicolaus } \\
\text { Deak }\end{array}$ & $1456-$ & $\begin{array}{l}\text { iudex, } \\
\text { iuratus }\end{array}$ & & & & $\begin{array}{l}\text { DF 247899. } \\
\text { Már. Dipl. } \\
403-429 ., \\
\text { DF 247907. }\end{array}$ \\
\hline $\begin{array}{l}\text { Thomas } \\
\text { Nerges }\end{array}$ & 1456 & iudex & & & nyerges & DF 247899. \\
\hline $\begin{array}{l}\text { Demetrius } \\
\text { litteratus }\end{array}$ & 1459 & & & & & $\begin{array}{l}\text { Már. Dipl. } \\
429 .\end{array}$ \\
\hline $\begin{array}{l}\text { Petrus man- } \\
\text { cus litteratus }\end{array}$ & 1468 & & & & DL 90433. \\
\hline $\begin{array}{l}\text { Valentinus } \\
\text { Fabyan }\end{array}$ & 1499 & iudex & & & & DF 247927. \\
\hline Elias Kalagor & 1499 & & & & & DF 247927. \\
\hline $\begin{array}{l}\text { Laurentius } \\
\text { Pal }\end{array}$ & 1499 & iuratus & & & & \\
\hline
\end{tabular}

\subsection{Huszt}

\begin{tabular}{|l|l|l|l|l|l|l|}
\hline \multicolumn{1}{|c|}{ Név } & Évszám & $\begin{array}{c}\text { Tanács- } \\
\text { tagság }\end{array}$ & Birtokok & $\begin{array}{c}\text { Nemesi } \\
\text { cím }\end{array}$ & $\begin{array}{c}\text { Foglal- } \\
\text { kozás }\end{array}$ & \multicolumn{1}{|c|}{ Forrás } \\
\hline Ladislaus & 1404 & villicus & & & & DL 2539. \\
\hline $\begin{array}{l}\text { Clemens } \\
\text { litteratus }\end{array}$ & 1406 & & malom & & & $\begin{array}{l}\text { Kovács } \\
1987.123 .\end{array}$ \\
\hline $\begin{array}{l}\text { Benedictus } \\
\text { magnus }\end{array}$ & 1435 & villicus & & & & DL 2539. \\
\hline
\end{tabular}

${ }^{443}$ Az alábbiakban a máramarosi mezővárosok lakóinak áttekintő listáját közlöm. A dátumnál mindig a forrásban való megjelenés éve vagy több forrás esetén intervalluma szerepel. A háztulajdont csak akkor tüntetem fel, ha az nem a lakóhelyén van. A birtokokat csak indokolt esetben részletezem, az ezzel kapcsolatos adatok a szövegben megtalálhatók. A kamara különféle, oklevelekben feltűnő alkalmazottait csak akkor veszem városlakónak, ha erre konkrét adat is van, még ha feltételezhető is, hogy a rónai kamara alkalmazottai nagyrészt Szigeten, a huszti kamaráé pedig Huszton éltek. 


\begin{tabular}{|c|c|c|c|c|c|c|}
\hline $\begin{array}{l}\text { Lucas de } \\
\text { Baranya }^{444}\end{array}$ & 1408 & & malom & van & & $\begin{array}{l}\text { Már. Dipl. } \\
\text { 156-157. }\end{array}$ \\
\hline $\begin{array}{l}\text { Iohannes de } \\
\text { Keselewme- } \\
\text { zew }\end{array}$ & 1450 & & $\begin{array}{l}\text { nemesi birto- } \\
\text { kok }\end{array}$ & van & & $\begin{array}{l}\text { Már. Dipl. } \\
344 .\end{array}$ \\
\hline $\begin{array}{l}\text { Paulus de } \\
\text { Keselewme- } \\
\text { zew }\end{array}$ & 1450 & & $\begin{array}{l}\text { nemesi birto- } \\
\text { kok }\end{array}$ & van & & $\begin{array}{l}\text { Már. Dipl. } \\
344 .\end{array}$ \\
\hline $\begin{array}{l}\text { Iohannes } \\
\text { filius Ladislai } \\
\text { de Hwztthy }\end{array}$ & 1456 & & & & & $\begin{array}{l}\text { Már. Dipl. } \\
377 .\end{array}$ \\
\hline Elyas Magyar & 1459 & & & & & $\begin{array}{l}\text { Már. Dipl. } \\
429 \text {. }\end{array}$ \\
\hline $\begin{array}{l}\text { Iohannes } \\
\text { Ladislaus (!) }\end{array}$ & 1459 & & & & & $\begin{array}{l}\text { Már. Dipl. } \\
429 .\end{array}$ \\
\hline Paulus Einz & 1459 & & & & & $\begin{array}{l}\text { Már. Dipl. } \\
429 .\end{array}$ \\
\hline $\begin{array}{l}\text { Michael } \\
\text { Zabo }\end{array}$ & 1478 & iudex & & & szabó & DL 70984. \\
\hline $\begin{array}{l}\text { Gregorius } \\
\text { Thamas }\end{array}$ & 1478 & & & & & DL 70984. \\
\hline $\begin{array}{l}\text { Iacobus } \\
\text { parvus }\end{array}$ & 1478 & & & & & DL 70984. \\
\hline $\begin{array}{l}\text { Iohannes } \\
\text { faber }\end{array}$ & 1478 & & $\begin{array}{l}\text { több ingat- } \\
\operatorname{lan}^{445}\end{array}$ & & kovács & DL 70984. \\
\hline $\begin{array}{l}\text { Iohannes } \\
\text { litteratus }\end{array}$ & 1478 & & malom $^{446}$ & & & DL 70984. \\
\hline $\begin{array}{l}\text { Cristoforus } \\
\text { clericus }\end{array}$ & 1478 & & malom & & & DL 70984. \\
\hline Urbanus & 1480 & iudex & & & & DF 285466. \\
\hline $\begin{array}{l}\text { Stephanus } \\
\text { Arday }\end{array}$ & $1480^{447}$ & & malom & & & DF 285466. \\
\hline $\begin{array}{l}\text { Laurentius } \\
\text { Arday }\end{array}$ & 1480 & & malom & & & DF 285466. \\
\hline $\begin{array}{l}\text { Matheus } \\
\text { corrigiator }\end{array}$ & 1480 & & & & $\begin{array}{l}\text { szíj- } \\
\text { gyártó }\end{array}$ & DF 285466. \\
\hline $\begin{array}{l}\text { Thomas } \\
\text { sartor }\end{array}$ & 1480 & & malom & & szabó & DF 285466. \\
\hline
\end{tabular}

\footnotetext{
${ }^{444}$ Fiaival együtt birtokol házat Huszton.

${ }^{445}$ Szántók, rétek, malmok, házak és földek. DL 70984.

${ }^{446}$ Közösen, testvérével Kristóffal.

${ }^{447}$ Ekkor már halott.
} 


\begin{tabular}{|c|c|c|c|c|c|}
\hline $\begin{array}{l}\text { Anthonius } \\
\text { Kosa }\end{array}$ & 1480 & & malom & & DF 285466. \\
\hline $\begin{array}{l}\text { Benedictus } \\
\text { litteratus de } \\
\text { Korpad }\end{array}$ & 1483 & & birtok $^{448}$ & & DL 45947. \\
\hline $\begin{array}{l}\text { Ambrosius } \\
\text { (Theremi) }\end{array}$ & 1485 & & birtok $^{449}$ & & $\begin{array}{l}\text { Már. Dipl. } \\
566 .\end{array}$ \\
\hline $\begin{array}{l}\text { Albertus } \\
\text { litteratus de } \\
\text { Theremy }\end{array}$ & $\begin{array}{l}1485- \\
1489\end{array}$ & & $\begin{array}{l}\text { telkek és } \\
\text { birtok }^{450}\end{array}$ & & $\begin{array}{l}\text { Már. Dipl. } \\
\text { 566-567., } \\
\text { 598. }\end{array}$ \\
\hline $\begin{array}{l}\text { Albertus } \\
\text { Nagh }\end{array}$ & $1487^{451}$ & & telkek $^{452}$ & & DL 66731. \\
\hline $\begin{array}{l}\text { Paulus } \\
\text { litteratus de } \\
\text { Ilmer }\end{array}$ & 1498 & & & & DL 71072. \\
\hline $\begin{array}{l}\text { Thomas } \\
\text { Emerici }\end{array}$ & 1504 & iudex & & & $\begin{array}{l}\text { DL 21247, } \\
\text { DL } 22477 .\end{array}$ \\
\hline $\begin{array}{l}\text { Stephanus } \\
\text { Thoth }\end{array}$ & 1504 & & & & DL 21247. \\
\hline $\begin{array}{l}\text { Paulus } \\
\text { Thoth }^{453} \\
\end{array}$ & 1504 & & & & DL 21247. \\
\hline $\begin{array}{l}\text { Nicolaus } \\
\text { Barylewyth/ } \\
\text { Dolgoz }\end{array}$ & $\begin{array}{l}1511- \\
1524\end{array}$ & & $\begin{array}{l}\text { telkek, mal- } \\
\text { mok, szőlők, } \\
\text { házak }\end{array}$ & van & $\begin{array}{l}\text { Szakály } \\
1985 .\end{array}$ \\
\hline $\begin{array}{l}\text { Benedictus } \\
\text { litteratus de } \\
\text { Hwzth alias } \\
\text { de Keselew- } \\
\text { mezew }\end{array}$ & $\begin{array}{l}1514- \\
1515\end{array}$ & & \begin{tabular}{|l|} 
nemesi birto- \\
kok, \\
szigeti ház
\end{tabular} & van & $\begin{array}{l}\text { Már. Dipl. } \\
\text { DL 72159, } \\
\text { DF } 212593 .\end{array}$ \\
\hline $\begin{array}{l}\text { Franciscus } \\
\text { litteratus }\end{array}$ & $\begin{array}{l}1514- \\
1515\end{array}$ & & szigeti ház ${ }^{454}$ & van & $\begin{array}{l}\text { DL } 86747, \\
\text { DF } 212593 .\end{array}$ \\
\hline $\begin{array}{l}\text { Andreas } \\
\text { Kwlchar }\end{array}$ & $1521^{455}$ & & & & DL 47398. \\
\hline
\end{tabular}

\footnotetext{
${ }^{448}$ Részbirtok Lipcsén.

${ }^{449}$ A Herincse melletti Chaholtzpathaka.

${ }^{450}$ A Herincse melletti Chaholtzpathaka, Herincsén összesen öt jobbágytelek, Lipcsén két jobbágytelek zálogban, 50 aranyforintért.

${ }^{451}$ 1521-ben már csak néhaiként beszélnek róla. DL 47398.

${ }^{452}$ Összesen hat telek Herincsén és Lipcsén.

${ }^{453}$ Stephanus Thoth fia, ekkor már halott, meggyilkolták, a gyilkosa (egregius) Monaky István.

${ }^{454} 1515$-ben ôt és Benedek literátust is szigeti háztulajdonosként sorolják fel, azonban a nevük mellett álló forensibus jelző alapján egyértelmű, hogy husztiak voltak. DF 212593.

${ }^{455}$ Ekkor már nem él.
} 


\begin{tabular}{|l|l|l|l|l|l|l|}
\hline $\begin{array}{l}\text { Gregorius } \\
\text { litteratus }\end{array}$ & 1521 & & & van & & DL 47398. \\
\hline $\begin{array}{l}\text { Benedictus } \\
\text { ollipar }\end{array}$ & 1521 & & & & fazekas & DL 47398. \\
\hline $\begin{array}{l}\text { Franciscus } \\
\text { Corpadi de } \\
\text { Hwzth }\end{array}$ & 1523 & & malom & van & & DF 247947. \\
\hline
\end{tabular}

\subsection{Sziget}

\begin{tabular}{|c|c|c|c|c|c|c|}
\hline Név & Évszám & $\begin{array}{l}\text { Tanács- } \\
\text { tagság }\end{array}$ & Birtokok & $\begin{array}{l}\text { Nemesi } \\
\text { cím }\end{array}$ & $\begin{array}{l}\text { Foglal- } \\
\text { kozás }\end{array}$ & Forrás \\
\hline $\begin{array}{l}\text { Nicolaus } \\
\text { Bogaz }\end{array}$ & 1383 & iudex & & & & $\begin{array}{l}\text { Már. Dipl. } \\
80 .\end{array}$ \\
\hline $\begin{array}{l}\text { Blasisus } \\
\text { Henkel filius } \\
\text { Fabiani }\end{array}$ & 1435 & & malom & & & DL 24953. \\
\hline $\begin{array}{l}\text { Martinus fili- } \\
\text { us Fabiani }\end{array}$ & 1435 & & malom & & & DL 24953. \\
\hline Simon & 1459 & iudex & & & & $\begin{array}{l}\text { Már. Dipl. } \\
429 .\end{array}$ \\
\hline $\begin{array}{l}\text { Georgius } \\
\text { litteratus }\end{array}$ & 1459 & & & & & $\begin{array}{l}\text { Már. Dipl. } \\
429 .\end{array}$ \\
\hline $\begin{array}{l}\text { Petrus littera- } \\
\text { tus de Zygeth }\end{array}$ & $\begin{array}{l}1459- \\
1460\end{array}$ & & birtok & van & & $\begin{array}{l}\text { DL 15414, } \\
\text { DL 15428., } \\
\text { Már. Dipl. } \\
429 .\end{array}$ \\
\hline $\begin{array}{l}\text { Thomas } \\
\text { Orsoly }\end{array}$ & 1460 & & birtok & & & DL 15428. \\
\hline $\begin{array}{l}\text { Gregorius } \\
\text { Kosa }\end{array}$ & 1460 & & birtok & & & DL 15428. \\
\hline Syle Pencz & 1460 & & birtok & & & DL 15428. \\
\hline $\begin{array}{l}\text { Stephanus } \\
\text { pellifex }\end{array}$ & $\begin{array}{l}1459- \\
1461\end{array}$ & iudex & & & szücs & $\begin{array}{l}\text { Már. Dipl. } \\
\text { 429-437. }\end{array}$ \\
\hline $\begin{array}{l}\text { Johannes } \\
\text { Derczeny }\end{array}$ & 1461 & iuratus & & & & $\begin{array}{l}\text { Már. Dipl. } \\
434 .\end{array}$ \\
\hline $\begin{array}{l}\text { Georgius } \\
\text { Pontz }\end{array}$ & 1461 & & & & & $\begin{array}{l}\text { Már. Dipl. } \\
434 .\end{array}$ \\
\hline $\begin{array}{l}\text { Michael } \\
\text { Sthibor }\end{array}$ & $\begin{array}{l}1461- \\
1464\end{array}$ & & & van & & $\begin{array}{l}\text { Már. Dipl. } \\
437-460 .\end{array}$ \\
\hline
\end{tabular}




\begin{tabular}{|c|c|c|c|c|c|}
\hline $\begin{array}{l}\text { Iohannes } \\
\text { literatus } \\
\text { theoloniator } \\
\text { in Zygeth }\end{array}$ & 1479 & & & & \begin{tabular}{|l} 
Teleki \\
gyömrői \\
316. sz.
\end{tabular} \\
\hline $\begin{array}{l}\text { Thomas } 456 \\
\text { litteratus }\end{array}$ & \begin{tabular}{|l}
$1491-$ \\
1505
\end{tabular} & & & & $\begin{array}{l}\text { DL 83957, } \\
\text { DL } 84083 .\end{array}$ \\
\hline $\begin{array}{l}\text { Johannes } \\
\text { Bothws }\end{array}$ & 1505 & földek, akol & & & DL 84083. \\
\hline $\begin{array}{l}\text { Gregorius } \\
\text { Gazda }\end{array}$ & 1505 & & & & DL 84083. \\
\hline $\begin{array}{l}\text { Mateus iudex } \\
\text { cysorum } \\
\text { salium }\end{array}$ & 1505 & & & & DL 84083. \\
\hline $\begin{array}{l}\text { Clemens } \\
\text { Bothws }\end{array}$ & 1505 & & & & DL 84083. \\
\hline $\begin{array}{l}\text { Stephanus }{ }^{457} \\
\text { Bothws }\end{array}$ & 1505 & föld & & & DL 84083. \\
\hline $\begin{array}{l}\text { Emericus } \\
\text { Bothws }^{458}\end{array}$ & 1505 & föld & & & DL 84083. \\
\hline Valentinus $^{459}$ & 1505 & föld & & & DL 84083. \\
\hline $\begin{array}{l}\text { Bartholomeus } \\
\text { litteratus de } \\
\text { Zygeth }\end{array}$ & 1515 & & van & & DF 212557. \\
\hline $\begin{array}{l}\text { Sigismundus } \\
\text { litteratus de } \\
\text { Checher }\end{array}$ & 1515 & & van & & DF 212593. \\
\hline $\begin{array}{l}\text { Petrus Ko- } \\
\text { wach }\end{array}$ & 1515 & & & kovács & DF 212593. \\
\hline Blasius Nylas & 1515 & & & & DF 212593. \\
\hline $\begin{array}{l}\text { Baltasar } \\
\text { Kazzo }\end{array}$ & 1515 & & & & DF 212593. \\
\hline $\begin{array}{l}\text { Georgius } \\
\text { litteratus de } \\
\text { Zygeth }\end{array}$ & $\begin{array}{l}1519- \\
1521\end{array}$ & $\begin{array}{l}2 \text { malom, } \\
\text { huszti ház }\end{array}$ & van & & $\begin{array}{l}\text { DF 212556, } \\
\text { DL 47398. }\end{array}$ \\
\hline $\begin{array}{l}\text { Matheus } \\
\text { Hwhnghy }\end{array}$ & 1519 & & & & DF 212556. \\
\hline $\begin{array}{l}\text { Georgius } \\
\text { Kossa }\end{array}$ & 1519 & & & & DF 212556. \\
\hline
\end{tabular}

\footnotetext{
${ }^{456}$ Fia szigeti pap és malombirtokos.

${ }^{457}$ Bothws János fia.

${ }^{458}$ Bothws János fia.

${ }^{459}$ Bothws János unokája.
} 


\begin{tabular}{|l|l|l|l|l|l|l|}
\hline $\begin{array}{l}\text { Stephanus } \\
\text { Wago }\end{array}$ & 1519 & & & & sóvágó & DF 212556. \\
\hline Petrus $^{460}$ & 1519 & & 2 malom & van & & DF 212556. \\
\hline
\end{tabular}

\subsection{Técső}

\begin{tabular}{|l|l|l|l|l|l|l|}
\hline \multicolumn{1}{|c|}{ Név } & Évszám & $\begin{array}{l}\text { Tanács- } \\
\text { tagság }\end{array}$ & Birtokok & $\begin{array}{c}\text { Nemesi } \\
\text { cím }\end{array}$ & $\begin{array}{c}\text { Foglal- } \\
\text { ko-zás }\end{array}$ & \multicolumn{1}{|c|}{ Forrás } \\
\hline $\begin{array}{l}\text { Corardo filius } \\
\text { Iacobi }\end{array}$ & 1336 & & & & & $\begin{array}{l}\text { Már. Dipl. } \\
13\end{array}$ \\
\hline Franciscus & 1404 & villicus & & & & DL 2539. \\
\hline Paulus Neste & 1456 & iudex & & & & DF 247901. \\
\hline $\begin{array}{l}\text { Clemens } \\
\text { Honnos }\end{array}$ & 1456 & iudex & & & & DF 247901. \\
\hline $\begin{array}{l}\text { Mathyas } \\
\text { Barkazy }\end{array}$ & 1456 & iudex & & & & DF 247901. \\
\hline Thomas Zay & 1456 & iudex & & & & DF 247901. \\
\hline $\begin{array}{l}\text { Blasius Thako } \\
1500\end{array}$ & & & & & $\begin{array}{l}\text { Már. Dipl. } \\
633 .\end{array}$ \\
\hline $\begin{array}{l}\text { Michael } \\
\text { Thako }\end{array}$ & 1500 & & & & & $\begin{array}{l}\text { Már. Dipl. } \\
633 .\end{array}$ \\
\hline
\end{tabular}

\subsection{Visk}

\begin{tabular}{|l|l|l|l|l|l|l|}
\hline \multicolumn{1}{|c|}{ Név } & Évszám & $\begin{array}{c}\text { Tanács- } \\
\text { tagság }\end{array}$ & Birtokok & $\begin{array}{c}\text { Nemesi } \\
\text { cím }\end{array}$ & $\begin{array}{c}\text { Foglal- } \\
\text { kozás }\end{array}$ & \multicolumn{1}{|c|}{ Forrás } \\
\hline $\begin{array}{l}\text { Franciscus filius } \\
\text { Nicolai }\end{array}$ & 1352 & & & & & DL 2539. \\
\hline Georgius & 1404 & villicus & & & & DL 2539. \\
\hline $\begin{array}{l}\text { Iohannes dictus } \\
\text { Kethel }\end{array}$ & 1435 & villicus & & & & DL 2539. \\
\hline Nicolaus Orosz & 1456 & & & & & $\begin{array}{l}\text { Már. Dipl. } \\
\text { 377. }\end{array}$ \\
\hline
\end{tabular}

\footnotetext{
${ }^{460}$ Szigeti litteratus György testvére.
} 


\section{FELHASZNÁLT IRODALOM}

Anjou = Anjou-kori oklevéltár. 1301-1387. Documenta res Hungaricas tempore regum Andegavensium illustrantia. Praeside Julio Kristó. Adiuvantibus Tiburtio Almási, Ladislao Blazovich, Geisa Érszegi, Francisco Makk, Francisco Piti. I-XV. (1301-1331), XVII. (1333), XIXXX. (1335-1336), XXII-XXVII. (1338-1343). Szerk. Almási Tibor-Blazovich László-Géczi Lajos-Kőfalvi Tamás-Piti Ferenc-Sebők FerencTóth Ildikó. Bp.-Szeged, 1990-2007.

Aragóniai Beatrix = Gerevich Tibor-Jakubovics Emil-Berzeviczy Antal: Aragoniai Beatrix magyar királyné életére vonatkozó okiratok. Bp., 1914. (Monumenta Hungariae Historica. Diplomata 39.)

Armális 1899. = II. Lajos király egy érdekes armálisa. Turul 9 (1891) 159. (szerző nélkül!)

ÁÚO = Wenzel Gusztáv: Árpád-kori új okmánytár. Codex Diplomaticus Arpadianus Continuatus. I-XII. Pest-Bp., 1860-1873.

Bartal = Antonius Bartal: Glossarium mediae et infimae latinitatis Regni Hungarie. Lipsiae, 1901.

Bártfa = Iványi Béla: Bártfa Szabad Királyi Város levéltára 1319-1526. I. Kötet. 1319-től 1501-ig. Bp., 1910; II. Kötet. 1501-től 1526-ig. Bp., é. n. (kézirat)

Bácskai 1964. = Bácskai Vera: Mezőgazdasági árutermelés és árucsere a mezővárosokban a 15. században. Agrártörténeti Szemle 6 (1964) 1-35.

Bácskai 1965. = Bácskai Vera: Magyar mezővárosok a 15. században. Bp., 1965. (Értekezések a történeti tudományok köréből. Új sorozat 37.) 
Bácskai 1971. = Bácskai Vera: A mezővárosi önkormányzat a 15. században és a 16. század elején. In: Tanulmányok a magyar helyi önkormányzat múltjából. Szerk. Bónis György-Degré Alajos. Bp., 1971. 9-31.

Bácskai 2002. = Bácskai Vera: Városok Magyarországon az iparosodás előtt. Bp., 2002.

Bánffy = Varjú Elemér-Iványi Béla: Oklevéltár a Tomaj-nemzetségbeli losonczi Bánffy család történetéhez. I. (1214-1457), II. (1458-1526). Bp., 1908-1948.

Bátori $=$ Politikatörténeti források Bátori István első helytartóságához (1522-1523). Közzéteszi: C. Tóth Norbert. Bp., 2010. (Magyar Országos Levéltár kiadványai II. Forráskiadványok 50.)

S. Benedek 1999. = S. Benedek András: A máramarosi koronavárosok. A polgári létforma fél évezrede egy viharos sorsú városszövetségben. Kisebbségkutatás 8 (1999) 207-211.

Bélay 1943. = Bélay Vilmos: Máramaros megye társadalma és nemzetiségei: a megye betelepülésétől a 18. század elejéig. Bp., 1943. (Településés népiségtörténeti értekezések 7.)

Bogdán 1991. = Bogdán István: Magyarországi űr-, térfogat-, súly- és darabmértékek 1874-ig. Budapest, 1991.

Bónis 1969. = Bónis György: A személynök és bírótársai a Jagellók korában. Századok 103 (1969) 5-29.

$\mathrm{CDH}=$ Codex Diplomaticus Hungariae Ecclesiasticus ac Civilis I-XI. Stud. Et op. Georgii Fejér. Budae, 1829-1844.

$\mathrm{CJH}=$ Corpus Juris Hungarici. Magyar törvénytár. 1000-1526. évi törvényczikkek. Fordította és jegyzetekkel ellátta Nagy Gyula-Kolosvári Sándor-Óvári Kelemen-Márkus Dezső. Bp., 1899.

Csatáry 1993. = Csatáry György: Levéltári kalászatok (tanulmányok, szövegközlemények). Ungvár-Bp., 1993. (Kárpátaljai magyar könyvek 21.)

Csatáry 1995. = Csatáry György: Múltunk írott ereklyéi (tanulmányok, dokumentumok). Ungvár-Bp., 1995. (Kárpátaljai magyar könyvek 62.)

Csatáry 2011. = Csatáry György: A máramarosi öt koronaváros levéltára 1326-1910. Ungvár-Beregszász, 2011.

Csánki 1889. = Csánki Dezső: Máramaros megye és az oláhság a 15. században. Századok 23 (1889), pótfüzet 27-46.

Csánki 1890-1913. = Csánki Dezső: Magyarország történelmi földrajza a Hunyadiak korában I-III., V. Bp., 1890-1913. 
Csukovits 1997. = Csukovits Enikő: Sedriahelyek - megyeszékhelyek a középkorban. Történelmi Szemle 39 (1997) 363-386.

Csukovits 2000. = Csukovits Enikő: A római Szentlélek-Társulat magyar tagjai (1446-1523). Századok 134 (2000) 211-244.

Czébely 2002. = Czébely Lajos: Visk története. Ungvár, 2002.

Deschmann 1991. = Deschmann Alajos: Huszt vára - a máramarosi sóbányák őre. Müemlékvédelem 35 (1991) 3. sz. 156-164.

DF = Magyar Nemzeti Levéltár, Magyar Országos Levéltár, Diplomatikai Fényképgyüjtemény

Diaconescu 1998-1999. = Marius Diaconescu: Biserica catolică din Maramureş în sec. XIII-XVI. Satu Mare 15-16 (1998-1999) 277-293.

DL = Magyar Nemzeti Levéltár, Magyar Országos Levéltár, Diplomatikai Levéltár.

DL-DF CD-ROM = Collectio Diplomatica Hungarica. A középkori Magyarország digitális levéltára. CD-ROM. Szerk. Rácz György. Bp., 2009.

Draskóczy 1994. = Draskóczy István: Olaszok a 15. századi Erdélyben. In: Scripta manent. Ünnepi tanulmányok a 60. életévét betöltött Gerics József professzor tiszteletére. Szerk. Draskóczy István. Bp., 1994. 125-135.

Draskóczy 2004. = Draskóczy István: A sóigazgatás 1397. esztendei reformjáról. In: Változatok a történelemre. Tanulmányok Székely György tiszteletére. Szerk. Erdei Gyöngyi-Nagy Balázs. Bp., 2004. (Monumenta Historica Budapestinensia XIV.)

Draskóczy 2005. = Draskóczy István: Szempontok az erdélyi sóbányászat 15-16. századi történetéhez. In: Studia Professoris - Professor Studiorum. Tanulmányok Érszegi Géza hatvanadik születésnapjára. Szerk. Almási Tibor-Draskóczy István-Jancsó Éva. Bp., 2005.

Draskóczy 2008. = Draskóczy István: Só a középkori Magyarországon. In: Gazdaság és gazdálkodás a középkori Magyarországon: gazdaságtörténet, anyagi kultúra, régészet. Szerk. Kubinyi András-Laszlovszky József-Szabó Péter. Bp., 2008. 147-162.

Draskóczy 2009a. = Draskóczy István: Nagybánya bányászata az 1480-as években. Szempontok a város pecsétjének történetéhez. In: Auxilium Historiae. tanulmányok a hetvenesztendős Bertényi Iván tiszteletére. Szerk. Körmendi Tamás-Thoroczkay Gábor. Bp., 2009. 105-113. 
Draskóczy 2009b. = Draskóczy István: A lengyel só a magyar királyságban a 15. század második felében és a 16. század elején. Szempontok a magyar forint lengyelországi elterjedéséhez. In: Pénztörténet - gazdaságtörténet. Tanulmányok Búza János 70. születésnapjára. Szerk. Bessenyei József-Draskóczy István. Bp.-Miskolc, 2009. 111-124.

Draskóczy 2010. $=$ Draskóczy István: 15. századi olasz jelentés Erdély ásványi kincseiről. In: Emlékkönyv ifj. Barta János 70. születésnapjára. Szerk. Papp Imre-Angi János-Pallai László. Debrecen, 2010. 49-59.

Draskóczy 2011. = Draskóczy István: Sókamara és város-vidék kapcsolata Debrecenben az 1430-as években. In: Debrecen város 650 éves. Várostörténeti tanulmányok. Szerk. Bárány Attila-Papp Klára-Szálkai Tamás. Debrecen, 2011. (Speculum Historiae Debreceniense 7.) 149172.

Draskóczy 2014. = Draskóczy István: Sóbányászat és -kereskedelem Magyarországon a középkorban. Valóság 57 (2014) 4. sz. 56-67.

Engel 1977. = Engel Pál: Királyi hatalom és arisztokrácia viszonya a Zsigmond-korban (1387-1437). Bp., 1977.

Engel 1985. = Engel Pál: Ung megye településviszonyai és népessége a Zsigmond-korban. Századok 119 (1985). 941-1005.

Engel 1988. = Engel Pál: Az ország újraegyesítése. I. Károly küzdelmei az oligarchák ellen (1310-1323). Századok 122 (1988) 89-147.

Engel 1996. = Engel Pál: Magyarország világi archontológiája 1301-1457. I-II. Bp., 1996. (História Könyvtár. Kronológiák, adattárak 5.)

Engel 2001. = Engel Pál: Magyarország a középkor végén. CD-ROM. MTA Történettudományi Intézet. Bp., 2001.

Eperjes = Iványi Béla: Eperjes Szabad Királyi Város Levéltára 1245-1526. Szeged, 1931.

Filipaşcu 1940. = Alexandru Filipaşcu: Istoria Maramureşului. Bucureşti, 1940.

Fényes 1851. = Fényes Elek: Magyarország geographiai szótára. I-II. Pest, 1851.

Frivaldszky 2005. = Frivaldszky János: Néhány adat a románság magyarországi történetéhez. Századok 139 (2005). 449-457.

Fügedi 1972. = Fügedi Erik: Koldulórendek és városfejlődés Magyarországon. Századok 106 (1972). 69-95.

Fügedi 1977. = Fügedi Erik: Vár és társadalom a 13-14. századi Magyarországon. Bp., 1977. 
Fügedi 1979. = Fügedi Erik: A befogadó: a középkori magyar királyság. Történelmi Szemle 22 (1979). 355-376.

Fügedi 1981. = Fügedi Erik: Középkori magyar városprivilégiumok. In: Uő: Kolduló barátok, polgárok, nemesek. Tanulmányok a magyar középkorról. Bp., 1981. 238-310. Megjelent még: Tanulmányok Budapest Múltjából 14 (1961). 17-107.

B. Gábor 1975. = B. Gábor Zsuzsa: Visk magyar lakosainak történeti és mai családnevei. Bp., 1975. (Magyar személynévi adattárak 5.)

Gábriel 1998. = Gábriel András: Máramaros. Honismeret 26 (1998) 1. szám, $17-22$.

Glück 2007. = Glück László: Máramarossziget mezőváros helyrajza és társadalma 1600 táján. In: Diszciplinák határain innen és túl. Szerk. Balogh Margit. Bp. 2007. 427-445.

Glück 2008a. = Glück László: Az öt máramarosi város lakosságának elnemesedése a 17. században. Urbs 3 (2008) 95-110.

Glück 2008b. = Glück László: A máramarosi só kereskedelmének útvonalai a 16. század közepén. Történelmi Szemle 50 (2008) 11-37.

Glück 2009a. = Glück László: A máramarosi sókamara igazgatása és gazdálkodása a szepesi kamara fennhatósága idején (1600-1604, 16141615). Revista arhivei maramureşene 2 (2009) 31-81.

Glück 2009b. = Glück László: Von der Spitze der Selbständigkeit an die Schwelle der „Rentnerschaft“. Der Weg einer Unternehmerfamilie an der Wende vom 16. zum 17. Jahrhundert. Anuarul Institutului de Cercetări Socio-Umane „Gheorghe Şincai“ 12 (2009) 215-238. (Magyarul megjelent: Az önállóság csúcsától a járadékosság küszöbéig. Egy vállalkozócsalád útja a 16-17. század fordulójának Magyarországán. http://www.maramarossziget.info/egy-vallalkozocsalad-utja/ letöltés ideje: 2014. február 13.)

Glück 2010. = Glück László: A máramarosi sókamara személyzete 1600 táján. Revista arhivei maramureşene 3 (2010) 41-80.

Glück 2013. = Az öt máramarosi város társadalma a 16-18. században. PhD-értekezés. Pécs, 2013. (kézirat)

Granasztói 1980. = Granasztói György: A középkori magyar város. Bp., 1980.

Gulyás 2008a. = Gulyás László Szabolcs: A mezővárosi önkormányzat funkciói és társadalmi háttere a középkori Hegyalján. Doktori (PhD) diszertáció. Debrecen, 2008. 
Gulyás 2008b. = Gulyás László Szabolcs: Középkori mezővárosi foglalkozásneveink forrásértékéről. Századok 142 (2008) 437-462.

Gulyás 2009. = Gulyás László Szabolcs: A középkori mezővárosok gazdasági-társadalmi szerepének megítélése a történeti szakirodalomban. Valóság 52 (2009) 2. sz. 69-81.

Gulyás 2011. = Gulyás László Szabolcs: Mezővárosi polgárok kegyes adományai a középkorban. In: Debrecen város 650 éves. Várostörténeti tanulmányok. Szerk. Bárány Attila-Papp Klára-Szálkai Tamás. Debrecen, 2011. (Speculum Historiae Debreceniense. A Debreceni Egyetem Történelmi Intézet Kiadványai 7.) 183-204.

Gulyás 2013. = Gulyás László Szabolcs: Megjegyzések az északkelet-magyarországi mezővárosok középkori fejlődésének jellemzőihez. Századok 147 (2013) 317-346.

Guzsik 2003. = Guzsik Tamás: A pálos rend építészete a középkori Magyarországon. Bp., 2003.

Györffy = Györffy György: Az Árpád-kori Magyarország történeti földrajza. Geographia historica Hungariae tempore stirpis Arpadianae. I-IV., Bp., 1963-1998.

Hervay 1984. = Hervay Ferenc: A pálos rend elterjedése Magyarországon . In: Mályusz Elemér emlékkönyv. Társadalom- és művelődéstörténeti tanulmányok. Szerk. H. Balázs Éva-Fügedi Erik-Maksay Ferenc. Bp., 1984. 159-171.

HO = Hazai okmánytár. Codex Diplomaticus Patriae. I-VIII. Kiadja Nagy Imre-Paur Iván-Ráth Károly-Véghely Dezső. Győr, Bp., 1865-1891.

Hóman 1921. = Hóman Bálint: A magyar királyság pénzügyei és gazdaságpolitikája Károly Róbert korában. Bp., 1921.

Horváth 2012. = Horváth Richárd: A Bélteki Drágfiak és a királyi család kapcsolata a Hunyadiak korában. In: A Szilágyság és a Wesselényi család (14-17. század). Szerk. Hegyi Géza-W. Kovács András. Kolozsvár, 2012. (Erdélyi Tudományos Füzetek 27.) 167-212.

Igyártó 2003. = Igyártó Gyöngyi: Koronavárosok Máramarosban. Együtt 2 (2003) 2. sz. 72-82.

Igyártó 2005. = Igyártó Gyöngyi: A máramarosi koronavárosok. UngvárBp., 2005.

Iványi 1911. = Iványi Béla: Két középkori sóbánya-statutum. Századok 45 (1911) 10-30., 98-113., 187-195. 
Kállay = A Nagykállói Kállay-család levéltára. (Az oklevelek és egyéb iratok kivonatai) I-II. (A Magyar Heraldikai és Genealógiai Társaság Kiadványai 1-2. szám) Budapest, 1943.

Kenyeres 2001. = Kenyeres István: A végvárak uradalmainak igazgatása és gazdálkodása a 16. században. Századok 135 (2001) 1350-1412.

Kenyeres 2004. = Kenyeres István: A királyi és királynéi „magánbirtokok” a 16. században. Századok 138 (2004) 1103-1148.

Kerekes 1988. = Kerekes Árpád: Néhány megjegyzés a máramarosi sóbányászatról. Hozzászólás Dr. Kovássy Zoltán: „A máramarosi sóbányászat emlékei" címü cikkéhez. Bányászati és Kohászati Lapok. Bányászat 121 (1988) 122-126.

Kiss 1988. = Kiss Lajos: Földrajzi nevek etimológiai szótára. I-II. Bp., 1988.

Komáromy 1894. = Komáromy András: Nyalábvár és uradalma. Századok 28 (1894) 492-519.

Kovács 1987. = Kovács Béla: Az egri egyházmegye története 1596-ig. Eger, 1987.

Kovássy 1986. = Kovássy Zoltán: A máramarosi sóbányászat emlékei. Bányászati és kohászati lapok. Bányászat 119 (1986) 626-631.

Kovássy 1988. = Kovássy Zoltán: Válasz Kerekes Árpád megjegyzéseire a máramarosi sóbányászat kérdésében. Bányászati és kohászati lapok. Bányászat 121 (1988) 127-130.

Középkori oklevelek : Balogh István - Érszegi Géza: Középkori oklevelek a Szabolcs-Szatmár-Bereg Megyei Levéltárban 1300-1525. Nyíregyháza, 2000. (A Szabolcs-Szatmár-Bereg Megyei Levéltár kiadványai II. Közlemények 21.)

Kring 1935. = Kring Miklós: Jobbágyságunk szabad költözéséről. Századok 69 (1935) 390-413.

Kristó 1988. = Kristó Gyula: A vármegyék kialakulása Magyarországon. Bp., 1988.

Kristó 1999. = Kristó Gyula: I. Károly király fơúri elitje (1301-1309). Századok 133 (1999) 41-62.

Kristó 2002. = Kristó Gyula: A korai Erdély. Szeged, 2002. (Szegedi Középkortörténeti Könyvtár 18.)

Kristó 2003. = Kristó Gyula: I. Károly király harcai a tartományurak ellen (1310-1323). Századok 137 (2003) 297-347.

Kubinyi 1971a. = Kubinyi András: A középkori magyarországi városhálózat hierarchikus térbeli rendjének kérdéséhez. Településtudományi Közlemények 23 (1971) 58-78. 
Kubinyi 1971b. = Kubinyi András: A budai német patríciátus társadalmi helyzete családi összeköttetéseinek tükrében a 13. századtól a 15. század második feléig. Levéltári Közlemények 42 (1971) 203-265.

Kubinyi 1973. = Kubinyi András: Budapest története a későbbi középkorban Buda elestéig (1541-ig). In: Budapest története II. Budapest története a későbbi középkorban és a török hódoltság idején. Szerk Gerevich László. Bp., 9-240.

Kubinyi 1994. = Kubinyi András: A Jagelló-kori Magyarország történetének vázlata. Századok 128 (1994) 288-319.

Kubinyi 1999a. $=$ Kubinyi András: Nemesi szabadság-jobbágyi szabadság. Falusi önkormányzat a késő középkorban. In: A középkor szeretete. Történeti tanulmányok Sz. Jónás Ilona tiszteletére. Szerk. Klaniczay Gábor-Nagy Balázs. Bp., 1999. 245-256.

Kubinyi 1999b. = Kubinyi András: Vallásos társulatok a késő középkori magyarországi városokban. In: uő: Főpapok, egyházi intézmények és vallásosság a középkori Magyarországon. Bp., 1999. (METEM Könyvek 22.) 341-352.

Kubinyi 2000. = Kubinyi András: Városfejlődés és vásárhálózat a középkori Alföldön és az Alföld szélén. Szeged, 2000. (Dél-alföldi évszázadok 14.)

Kubinyi 2003. = Kubinyi András: Családnévadás a középkori Magyarországon. In: In virtute spiritus. A Szent István Akadémia emlékkönyve Paskai László bíboros tiszteletére. Szerk. Stirling János. Bp., 2003. 96-112.

Kubinyi 2004. = Kubinyi András: Ispotályok és városfejlődés a késő középkori Magyarországon. In: Analecta Mediaevalia II. Várak, templomok, ispotályok. Tanulmányok a magyar középkorról. Szerk. Neumann Tibor. Bp., 2004. 187-195.

Kubinyi 2005. = Kubinyi András: Városhálózat a késő középkori Kárpátmedencében. In: Bártfától Pozsonyig. Városok a 13-17. században. Szerk. Csukovits Enikő-Lengyel Tünde. Bp., 2005. (Társadalom- és művelődéstörténeti tanulmányok 35.) 9-36.

Kubinyi 2006. = Kubinyi András: „Szabad királyi város” - királyi szabad város"? Urbs 1 (2006) 51-61.

Kulcsár 1991. = Kulcsár Árpád: Sóbányászat és sókereskedelem Erdélyben I. Apafi Mihály uralkodása idején. Századok 125 (1991) 415-448.

Kumorovitz 1928. = Kumorovitz Lajos Bernát: A leleszi konvent oklevéladó múködése 1569-ig. Turul 42 (1928). 1-2. sz. 1-39. 
Ladányi 1980. = Ladányi Erzsébet: Libera villa, civitas, oppidum. Terminológiai kérdések a magyar városfejlődésben. Történelmi Szemle 23 (1980) 450-477.

Ladányi 1992. = Ladányi Erzsébet: Az oppidum fogalom használata a középkori Magyarországon. Az oppidumok jogélete. Levéltári Szemle 42 (1992) 4. sz. 3-12.

Lakatos 2013. = Lakatos Bálint Péter: Hivatali írásbeliség és ügyintézés a késő középkori magyarországi mezővárosokban, okleveleik tükrében. Doktori Disszertáció. ELTE BTK, Budapest, 2013. (kézirat)

Lakatos 2014. = Lakatos Bálint: Mezővárosi és falusi önkormányzati testületek Magyarországon a késő középkorban. Századok 148 (2014) 495-530.

Lehoczky 1890. = Lehoczky Tivadar: Adalékok az oláh vajdák, oláh és orosz kenézek vagy soltészok és szabadosok intézményéhez hazánkban. Történelmi Tár 13 (1890) 155-173., 474-492.

Lelesz Stat. $=$ C. Tóth Norbert: A leleszi konvent Statutoriae sorozatának 1387-1410 közötti oklevelei (Pótlás a Zsigmondkori Oklevéltár I-II. köteteihez). Nyíregyháza, 2006. (A Szabolcs-Szatmár-Bereg megyei Levéltár Kiadványai. II. Közlemények 36.)

Magyar Okl. Rom. = Magyar vonatkozású oklevélközlések Romániában. Szerk. W. Kovács András. Kolozsvár, 2009. (Erdélyi Tudományos Füzetek 261.)

Majorossy Judit: A Krisztus Teste Konfraternitás helye a középkori pozsonyi polgárok életében. In: Bártfától Pozsonyig. Városok a 13-17. században. Szerk. Csukovits Enikő-Lengyel Tünde. (Társadalom- és művelődéstörténeti tanulmányok 35.) Bp., 2005. 253-291.

Maksay 1990. = Maksay Ferenc: Magyarország birtokviszonyai a 16. század közepén. I-II. Bp., 1990. (A Magyar Országos Levéltár Kiadványai. II. Forráskiadványok 16.)

Mályusz 1953. = Mályusz Elemér: A mezővárosi fejlődés. In: Tanulmányok a parasztság történetéhez Magyarországon a 14. században. Szerk. Székely György. Bp., 1953.

Már. Dipl. = Mihályi János: Máramarosi diplomák a XIV. és XV. századból. Máramarossziget, 1900.

Menasági 1994. $=$ Menasági Sándor: Románok. In: Korai magyar történeti lexikon (9-14. század). Főszerk. Kristó Gyula. Bp., 1994. 580-581.

Mihályi 1889. = Mihályi János: Tanulmány máramarosi oklevelekről. Századok 23., (1889) pótfüzet 57-67. 
MNL-OL = A Magyar Nemzeti Levéltár Országos Levéltára

$\mathrm{MTHJ}=\mathrm{A}$ magyar törvényhatóságok jogszabályainak gyüjteménye I-V Szerk. Kolosváry Sándor-Óváry Kelemen. Bp., 1885-1904.

Neumann 2012. = Neumann Tibor: Drágfi Bertalan politikai szerepe II. Ulászló király idején. In: A Szilágyság és a Wesselényi család (14-17. század). Szerk. Hegyi Géza-W. Kovács András. Kolozsvár, 2012. (Erdélyi Tudományos Füzetek 27.) 213-235.

Némedi Varga 1997. = Némedi Varga Zoltán: A Kárpát-medence hasznosítható, szilárd ásványi nyersanyag-előfordulásainak földtani áttekintése. In: A magyar bányászat évezredes története. I-III. köt. Szerk. Faller Gusztáv-Kun Béla-Zsámboki László. Bp., 1997. I. 19-28.

Németh 1975. = Németh Péter: Borsova határvármegye kialakulása. Kisvárda, 1975. (Tanulmányok Kisvárdáról 5.)

Nyegre 1900. = Nyegre László: Máramaros megye. Különlenyomat a „Közgazdasági Szemle” 1900. évi novemberi és deczemberi füzetéből. Bp., 1900.

Oborni 2002. = Oborni Teréz: Erdély pénzügyei I. Ferdinánd uralma alatt 1552-1556. Bp. 2002. (Fons könyvek 1.)

Pach 2001. = Pach Zsigmond Pál: A vidéki posztóipar az északkeleti országrészen a 15-17. században. Századok 135 (2001) 793-818.

Pap 1909. = Pap József: Adalékok Máramaros történetéhez. Máramarossziget, 1909.

Papp 1956. = Papp László: A 16. századi Literatus: Diák Deák nevek kérdéséhez. Magyar Nyelv 52 (1956) 480-481.

Paulinyi 2005. = Paulinyi Oszkár: A sóregálé kialakulása Magyarországon . In: uő: Gazdag föld - szegény ország. Tanulmányok a magyarországi bányaművelés múltjából. Szerk. Búza János-Draskóczy István. Bp., 2005. (Gazdaság- és társadalomtörténeti kötetek 3.) 11-25. Eredetileg megjelent: Századok 57-58 (1923-1924) 627-647.

Pálinkó 2012. = Pálinkó Tamás: Erdély, Máramaros és a Partium központi helyei és városai az Anjou-korban. Belvedere Meridionale 24 (2012) 4. sz. 117-124.

Perényi = Tringli István: A Perényi család levéltára 1222-1526. Bp., 2008. (Magyar Országos Levéltár kiadványai II. Forráskiadványok 44.)

Petrov 1925. = Petrov Elek: A máramarosi Szt.-Mihály monostor 1391-i görög oklevelének latin fordítása az 1494. évi megerősítő oklevélben. Turul 43 (1925) 23-24. 
Petrovay 1909. = Petrovay György: Oklevelek Máramaros vármegye történetéhez. Történelmi Tár 10 (1909) 3. sz. 358-378., 4. sz. 509-529.

Petrovay 1911. = Petrovay György: A máramarosi oláhok, betelepedésük, vajdáik és kenézeik. Századok 45 (1911) 607-626.

Petrovics 1994. = Petrovics István: Borsova. In: Korai magyar történeti lexikon (9-14. század). Főszerk. Kristó Gyula. Bp., 1994. 121-122.

Reg. Arp. = Az Árpád-házi királyok okleveleinek kritikai jegyzéke. Regesta regum stirpis Arpadianae critico-diplomatica. I-II/1. (1001-1272). Szerk. Szentpétery Imre. Bp., 1923-1943; II/2.-II/4. (1272-1301). Szentpétery Imre kéziratának felhasználásával szerk. Borsa Iván. Bp., 1961-1987. (Magyar Országos Levéltár Kiadványai II. Forráskiadványok $9,13$.$) .$

Réthy 2005. = Réthy Károly: Máramaros sóbányászata. Bányászati és kohászati lapok, Bányászat 138 (2005). 5. sz. 27-29.

Réthy-Tóth 2012. = Réthy Károly-Tóth János: Sótermelés és sószállítás a Kárpát-medencében. Zalaegerszeg, 2012. (Magyar Olajipari Múzeum közleményei 47.)

F. Romhányi 2000. = F. Romhányi Beatrix: Kolostorok és társaskáptalanok a középkori Magyarországon. Bp., 2000.

F. Romhányi 2007. = F. Romhányi Beatrix: Pálos gazdálkodás a 15-16. században. Századok 141 (2007) 299-351.

Schmidt 1901. = Schmidt László: A máramarosi bányászat fejlődésének története. Bányászati és kohászati lapok 34 (1901) 330-335.

Simonchicz $=$ Simonchicz Innocentius: Noctium Marmaticarum Vigiliae. Dissertatio de Terra Maramaros. é. n. Kézirat.

Skorka 2005.= Skorka Renáta: A céhrendszer kibontakozása. In: A magyar kézmüvesipar története. Szerkesztette Szulovszky János. Bp., 2005. 109-150.

Solymosi 1972. = Solymosi László: A jobbágyköltözésről szóló határozat helye a költözés gyakorlatában. Agrártörténeti Szemle 14 (1972) 1-40.

Solymosi 1994. = Solymosi László: Költözési illeték a 13-14. századi Magyarországon. In: Scripta manent. Ünnepi tanulmányok a 60. életévet betöltött Gerics József professzor tiszteletére. Szerk. Draskóczy István. Bp., 1994. 95-104.

Solymosi 1998. = Solymosi László: A földesúri járadékok új rendszere a 13. századi Magyarországon. Bp., 1998. 
Solymosi 1999. = Solymosi László: Két középkor végi testamentum Szabolcs vármegyéből. In: Emlékkönyv Rácz István 70. születésnapjára. Szerk. Kovács Ágnes. Debrecen, 1999. 203-225.

Szabados 1999. = Szabados György: Imre és András. Századok 133 (1999) 85-111.

Szabó I. 1954. = Szabó István: Az 1351. évi jobbágytörvények. Századok 88 (1954) 497-527.

Szabó I. 1994. = Szabó István: Ugocsa megye. Budapest-Beregszász, 1994.

Szabó Z. 1940. = Szabó Zoltán: Máramaros a népek találkozóhelye. Korunk 15 (1940) 222-227.

Szakály 1985. = Szakály Ferenc: Határmezsgyén. (Huszti Barilovics Miklós életútja, 1492-1537). Folia Historica 9 (1981) 7-25.

Szádeczky 1889. = Szádeczky Lajos: A kirándulás története. Századok 23, (1889) pótfüzet. A Magyar Történelmi Társulat 1889. aug. 25-31-iki vidéki kirándulása Máramaros vármegyébe és Nagy-Bánya városába. 139-152.

Szádeczky 1913. = Szádeczky Lajos: Iparfejlődés és a czéhek története Magyarországon I-II. Bp., 1913.

Szende K. 2011. = Szende Katalin: A magyar városok kiváltságolásának kezdetei. In: Debrecen város 650 éves. Várostörténeti tanulmányok. Szerk. Bárány Attila-Papp Klára-Szálkai Tamás. Debrecen, 2011. (Speculum Historiae Debreceniense 7.). 23-48.

Szende L. 2008. = Középkori kézművesség. In: Gazdaság és gazdálkodás a középkori Magyarországon. Gazaságtörténet, anyagi kultúra, régészet. Szerk. Kubinyi András-Laszlovszky József-Szende László. Bp., 2008. 199-228.

Szentpétery 1985. = Szentpétery Imre: A kronológia kézikönyve. A Chronologia és az Oklevéltani naptár összevont, javított és bővített kiadása. Az eredeti kiadást kieg. Érszegi Géza-Raj Tamás-Szögi László. A szerző hagyatékának felhasználásával sajtó alá rendezte: Gazda István. Bp., 1985.

Székely 1967. = Székely György: Középkori kézműves foglalkozások és a családnevek kialakulása. In: A magyar nyelv története és rendszere. A debreceni nemzetközi nyelvészkongresszus előadásai. Szerk. Imre Samu-Szatmári István. (Bp., 1967. Nyelvtudományi Értekezések 58.) 206-210.

Szilágyi 1876. = Szilágyi István: Máramaros vármegye egyetemes leírása. Bp., 1876. 
Szilágyi 1889. = Szilágyi István: Máramarosmegye általános történelméből (A 12. és 13. század). Századok 23, (1889) pótfüzet 10-26.

Szoleczky 2005. = Szoleczky Emese: Huszt várának helye és szerepe Magyarország védelmi rendszerében. In: Az értelem bátorsága. Tanulmányok Perjés Géza emlékére. Szerk. Hausner Gábor. Bp., 2005. 699-729.

Szoleczky 2012. = Szoleczky Emese: „Máramaros büszke vára...” Huszt vára a Rákóczi szabadságharc idején. Várak, kastélyok, templomok: történelmi és örökségturisztikai folyóirat. 8 (2012) 4. sz. 32-35.

Szöllőssy 1994. = Szöllősy Tibor: „Teccő nekem ez a hely”. Técső - mondák és tények tükrében. Ungvár-Bp., 1994.

Sztáray = Nagy Gyula: A nagymihályi és sztárai gróf Sztáray-család oklevéltára 1234-1457. I-II. Bp., 1887-1889.

Szücs 1955. = Szűcs Jenő: Városok és kézművesség a 15. századi Magyarországon. Bp., 1955.

Takáts 1929. = Takáts Sándor: Régi sóvágóinkról. In: uő: Emlékezzünk eleinkről. Bp., 1929. 69-78.

Hunyadiak kora = Teleki József: A Hunyadiak kora Magyarországon. Oklevéltár. I-XII. Pest, 1852-1863.

Teleki gyömrői = Iványi Béla: A római szent birodalmi széki gróf Telekicsalád gyömrői levéltára. Szeged, 1931.

C. Tóth 2006. = C. Tóth Norbert: Ugocsa megye hatóságának oklevelei (1290-1526). Bp., 2006.

C. Tóth 2012. $=$ C. Tóth Norbert: Szász vajda utódainak felemelkedése és bukása. A család vázlatos története 1365-1424 között. In: A Szilágyság és a Wesselényi család (14-17. század). Szerk. Hegyi Géza-W. Kovács András. Kolozsvár, 2012. (Erdélyi Tudományos Füzetek 27.) 135-166.

Tóth 2008. = Tóth Péter: A Técső helynév eredetéről. Magyar Nyelv 104 (2008) 208-210.

Tripartitum = Werbőczy István: Tripartitum. A dicsőséges Magyar Királyság szokásjogának hármaskönyve. Tudománytár. Sorozatszerk. Gazda István. Bp., 1990.

Vályi 1796. = Vályi András: Magyarországnak leírása. I-III. Buda, 1796.

Vékony 1996. = Vékony Gábor: Dákok - rómaiak - románok. In: Árpád előtt és után. Szerk. Kristó Gyula-Makk Ferenc. Szeged, 1996. 63-71.

Weisz 2012. = Weisz Boglárka: Vásárok és lerakatok a középkori Magyar Királyságban. Bp., 2012. 
Weisz 2013. = Weisz Boglárka: A királyketteje és az ispán harmada. Vámok és vámszedés Magyarországon a középkor első felében. (Magyar Történelmi Emlékek. Adattárak.) Bp., 2013.

Wenzel 1857. = Wenzel Gusztáv: Kritikai fejtegetések Máramaros megye történetéhez. Különnyomat a Magyar Akadémiai Értesítőből. Pest, 1857.

Wenzel 1880. = Wenzel Gusztáv: Magyarország bányászatának kritikai története. Bp., 1880.

Wertner 1913. = Wertner Mór: Családtörténelmi kalászat. Turul 31 (1913) $56-76$.

Zimányi 1980. = Zimányi Vera: Gazdasági és társadalmi fejlődés Mohácstól a 16. század végéig. Századok 114 (1980) 511-574.

Zsámboki 1997. = Bányászat az Árpádok korában (896-1301). In: A magyar bányászat évezredes története. I-III. Szerk. Faller Gusztáv-Kun BélaZsámboki László. Bp., 1997. I. 29-71.

ZSO = Zsigmond-kori oklevéltár I-XII. (1387-1425). Szerk. Mályusz ElemérBorsa Iván-C. Tóth Norbert-Neumann Tibor-Lakatos Bálint. (A Magyar Országos Levéltár Kiadványai II. Forráskiadványok 1., 3-4., 22., 25., 27., 32., 37., 39., 41., 43., 49., 52.) Bp., 1951-2013.

Zsoldos 2011. = Zsoldos Attila: Magyarország világi archontológiája 10001301. Bp., 2011. 


\section{SZEMÉLY- ÉS HELYNÉVMUTATÓ}

A

Abaúj megye 111

Abád 66

Ahelleus, Hontpázmány nb. 21

Aknasugatag ld. Sugatag

Albert

huszti deák 73

Istenmezei, sókamaraispán 26, 96

Nagy (magnus), huszti polgár 94

Theremi, huszti polgár 57,95

Almás 55

Alsóapsa 51, 77

Alsócsongova 56

Alsógerce 56

Alsó-Magyarországi bányavárosok 7

Alsóróna 61, 104

Alsósárad 56

Alsóvisó 105

Ambrus

rónaszéki várnagy 65

Sárkány, máramarosi sókamaraispán 26

András

III., magyar király 21, 49

de Bol, máramarosi alispán és alkamaraispán 64
Herepthysthe 56

Hintzi, máramarosi polgár 40

Kochys, szőllősi bíró 82

Lackfi, máramarosi ispán 20

Angelo Manini, dési, széki és mára-

marosi sókamaraispán 65, 66

Anna

huszti polgárnő 98

magyar királyné 29, 41

Antal

Kosa, huszti polgár 98

szigeti plébános 72

Antonius, konstantinápolyi pátriárka 52

Apáti 66

Aprusa 50

Apsai család 68

Apsai Mihályi János ld. Mihályi János Aranyos 24

Meggyes város 43

Ardó 21, 48, 56

Asszonypataka ld. Nagybánya

Avas-hegy 61 
B

B. Gábor Zsuzsa 14

Balázs

Henkel, Fábián fia, szigeti polgár 95

Keszi 111

Thot 104

Balk, Bélteki család, máramarosi oláh vajda $24,25,50,51,52,103$

Balotafalva 104

Baranyai család 93

Barcán 50

Barcánfalva 50, 95

Batarcs 56

Bálint

Pecsétes, huszti polgár 95

szigeti polgár 100

Bárdfalva 36, 61, 104

Bártfa város 7, 27, 72

Beatrix, magyar királyné 26, 28, 44, $51,67,69,73,94,96,111$

Becs 28, 62, 67

Bedőháza 23, 36, 50, 53, 57, 111

Belezna 105

Benedek

Batthyány, sókamaraispán 26

deák, rónaszéki tiszttartó 64

Himfi, szatmári ispán 24

Keselyümezei 94

Korpádi, deák, huszti polgár 94

Nagy (magnus), huszti villicus $40,49,79$

szigeti plébános 39

técsői plébános 23

Bereg megye 23, 51, 54, 55, 56, 57

Berezna 104

Beszterce város 29

Bertalan

Besenyői, sókamaraispán 26
Drágffy, Bélteki család, erdélyi vajda 104

Szigeti, deák 96

Bél Mátyás 9

Béla, IV., magyar király 10

Bélay Vilmos 13

Béltek 24

Bélteki család 24, 64

Bihar megye 23

Bilke 56

Bilkei család 31, 94

Bogdán, Mykola fia 50

Boldogasszonyfalva 66

Boleszló, esztergomi érsek 22, 23

Borsova megye 19

Borsova vár 19

Borzán ld. Barcán

Buda 7, 27

Budfalva 104

C

Chaholtzpathaka-völgy 95

Czébely Lajos 15

Cs

Csarnatő 56

Csatáry György 14

Csánki Dezső 11, 103

Császlóci család 56

Csebi család 105

Csepel-sziget 27, 28

Csertész 56

Csépán, Hontpázmány nb. 21

D

Dancs, királyi ember 53

Daróc 36

Debrecen mezőváros 70, 71 
Demeter

Balk fia, Bélteki család 25, 103

deák, hosszúmezei polgár 99

meggyesi provisor 43

Úrmezei Iván fia 104

Demko 56

Demkó Kálmán 11

Dénes, Úrmezei István fia 104

Déva 27

Diósgyőr 27

Disznópatak 62, 95

Dolha 57

Dolhai család 57

Domokos, Zólyomi Macska, huszti várnagy 22

Dorottya, szőllősi polgárnő 97, 98,

Draskóczy István 15, 65

Dragomérfalva 105

Drág, máramarosi és székely ispán, Bélteki család, 20, 24, 50, 51, 52, 103

Drágffy család 51

Dragomér, Szász fia 50

Dragos, Bedő fia 50

Dubinyapathaka 62

E

Eger város 22, 67

Engel Pál 20, 57, 103

Eperjes 7, 27, 67, 70, 74

Erdély 47, 69, 70

Erdői Nagy Pál ld. Baranyai Nagy Pál

Erzsébet

magyar királyné 51,72

szőllősi polgárnő 97, 98

Esztergom 7, 27

Eufrozina 105

\section{F}

Farkasfalva 36

Farnas-patak 95

Fejéregyház 19, 51, 105

Fejérfalva 104

Fejérpataky László 11

Feketeardó ld. Ardó

Fekete-erdő 41

Felsőapsa 51, 77, 104

Felsőbocskó 105

Felsőcsongova 56

Felsőgerce 56

Felsőróna 51

Felsősárad 56

Felsővisó 105

Felszász 19, 48, 56

Ferenc

deák, huszti polgár 95

Korpádi, huszti polgár 94

Manini 65

Miklós fia, viski hospes 39

Paládi, máramarosi ispán és sókamaraispán 26, 64, 73

técsői villicus 40,79

Fényes Elek 9

Fogaras 50

Fügedi Erik 110

G

Gábor, Perényi, sókamaraispán és ugocsai ispán 26, 27, 28, 43, 44, 64,67

Gáborján 66

Gánya 104

Gergely

Gazda, szigeti polgár 100

Kosa, szigeti polgár 96

Glück László 7, 9, 16, 17, 29, 89, 93, 108 
Gölnic vár 27

Görgény vár 27

Grapiolus máramarosi ispán, sókamaraispán 26, 72

Gy

Gyapjúpataka 92

Györffy György 14

György

Berendez 56

huszti plébános 23

Pontz, szigeti polgár 84

Rosa 54

Szigeti, litteratus 96, 97

viski plébános 23

viski villicus 40, 79

Gyula, Dragos fia 51

Gyulafalva 51, 52, 61

Gyulafalvi család 54

Gyula(háza) 56, 62

H

Hamylko 56

Hary Péter 9

Herincse 57, 94, 104

Hetény 95

Héder János 10

Hilarius, körtvélyesi apát 52

Hosszúmező mezőváros 7, 23, 24, 25, $26,29,34,36,39,40,44,48,49,52$, $53,61,62,64,70,75,76,77,78,79$, $80,81,83,84,87,92,93,99,101$, 110,111

Husztakna 62

Huszti Benedek ld. Keselyümezei Benedek

Huszt mezőváros 7, 23, 24, 25, 26, 28, $29,31,39,40,44,47,48,49,61,62$, $64,67,68,69,70,72,73,75,77,78$, $80,81,82,84,85,87,88,90,91,92$,
93, 94, 95, 97, 98, 99, 101,105, 110, 111,112

Huszt vár 9, 10, 15, 21, 24, 26, 27, 28, 51,68

I

Ilonca 56

Ilosva 56

Ilosvai család 94

Imre

Bothws, szigeti polgár 100

magyar király 19

Szapolyai, kincstartó 54, 66

váradi püspök 22

Ipoly folyó 70

Irholc 61

István

I., magyar király 59

Baranyai 93

Bedői 53

Bethlen 85

Bothws, szigeti polgár 100

huszti várnagy 65

ifjabb király és V., magyar király $21,36,52$

Perényi 43

Szász fia 50

szigeti bíró 54

Thoth 84

Werbőczy 94

Ivan

Thalchenycz 56

Zamoyla 56

Iványi Béla 13, 60

Iza 62

Iza folyó 23, 50, 95 
J

János

Baranyai 93

Bothws, szigeti polgár 100, 108

Calmar, szőllősi polgár 97

deák, János kovács fia 97, 98

deák, szigeti theoloniator 68

Horvát, máramarosi ispán 40, 72

Hunyadi, kormányzó 34, 66, 72, 94

Kállói Lökös 65

Keselyűmezei 94

Kethel dictus, viski villicus 40, 49,79

Kosolya 56

körtvélyesi apát 52

Laskody, máramarosi ispán 83

Manini 65

Munkalius, huszti várnagy 26

Oláh, vlah kenéz 51

Perényi, máramarosi ispán 42, 56

Pyriska 56

rónaszéki várnagy 65

Szapolyai, magyar király 28

szigeti plébános 23

szigeti polgár 96

Tárcai, sókamaraispán 26, 69

técsői plébános 72

K

Kalinfalva 104

Kandra Kabos 11

Karácsonyfalva 104

Kassa város 27, 29, 66, 67, 70

Kaszó 104

Károly I., magyar király 20, 23, 24, 29,

$33,36,37,40$

Kárpátalja 9, 14

Kárpát-medence 110
Kelemen

Bothws, szigeti polgár 100

deák, huszti polgár 111

Honnos, técsői esküdt 80

Mathei Mykocha fia 56

Kerecke 57

Kerekes Árpád 14

Keselyümezei család 94

Keselyümező 94

Keve (Rác-) 28

Királyháza $l d$. Felszász

Kirva 56

Kisfalud 56

Kis-Fátra 50

Kisszeben város 27

Kistécső $l d$. Técső

Kolozsvár város 7, 27

Komlós 56

Konstantinápoly 52

Konyha 24, 50

Koromlya 56

Kostha kovács (faber) 56

Kovássy Zoltán 14

Kökényes 61

Körössziget 105

Körtvélyes 52, 111

Kövesliget 104

Középapsa 51, 52, 77

Közép-Szolnok megye 52

Kővár 24

Krajna 51

Kristóf klerikus, huszti polgár 98

Kubinyi András 16, 107, 112

Kurima mezőváros 55, 81

Kusnica 57

\section{L}

Lajos

I. magyar király 23, 29, 39, 40, 51, $60,77,111$ 
II., magyar király 27, 28, 44, 67, 84,96

Lakatos Bálint 77

László

IV., magyar király 21

V., magyar király 40, 43, 63, 101

Erdélyi, máramarosi sókamaraispán 66

huszti villicus 40,79

Nagy (magnus), máramarosi ispán és huszti várnagy 64

Szalkai, váci püspök, kincstartó 26, 28, 96

Szentgyörgyi Vince, máramarosi ispán és sókamaraispán 64

titeli prépost 22

Upori, máramarosi ispán 54

Zyws, huszti polgár 31

Le Goff, Jacques 110

Leó, rutén herceg 21

Lipcse 94, 95, 104

Liszka mezőváros 81

Lőcse város 27

Lőrinc

Arday, huszti polgár 98

Baranyai, Lukács fia 93

hosszúmezei plébános 23

ispán 19

Szász, szigeti bíró 41, 80

vlah pap 51

Luc 66

Luchkemezeu 23

Lukács

Spacha 56

Szaploncai 53

Szécsi 104

Warsycz 56

Zamoyla 56

Lukova 56
M

macsói bánság 27

Makaria 55

Makovica vár 55

Maksay Ferenc 16

Marcellus comes, Hontpázmány nb. 21

Manini család 65

Maros folyó 50

Marus 50

Mályusz Elemér 13, 14

Máramaros megye $8,10,12,13,19$, $20,21,22,33,34,35,36,37,38,41$, $43,47,48,49,50,51,55,56,57,59$, $60,61,62,63,64,67,68,69,71,74$, $76,78,81,83,89,90,95,99,101$, $105,108,109,111,112$

Máramaros-erdő 19

Máramarossziget $l d$. Sziget

Mária, magyar királynő 28, 67, 94, 111

Márk, Manini 65

Márki Sándor 11

Márta, szigeti polgárnő 100

Márton, Fábián fia, szigeti polgár 95

Máté

Brod fia 56

Csák 37

sóvágóbíró, szigeti polgár 92, 100

Szegedi, sókamaraispán 26

szíjgyártó, huszti polgár 98

Thykoro-i Thykorozcky, királyi kamarás 105

Mátyás

I., magyar király 26, 29, 34, 40, $42,44,54,60,66,67,72,73$, 95, 101

Barkazy, técsői esküdt 80

Berendez 56

huszti oltárigazgató 73

Meggyes város 43

Meggyesalja 52 
Mezőség 23

Mihály

huszti várnagy és máramarosi alispán 64

Kozthyn 56

Kusalyi Jakcs, székely ispán 42

Pöstyéni, máramarosi ispán és sókamaraispán 64

Selpak 56

Stibor, szigeti polgár 54, 101

Zabo, huszti bíró 80

Mihályi János 11, 16, 25, 48, 52, 77

Miklós

Barilovics (Dolgos), huszti polgár $44,69,85,95,110$

Bátori, szerémi püspök 56

Bilkei 94

Bogaz, szigeti bíró 80

Deak, hosszúmezei polgár 99

Dyak, hosszúmezei esküdt és bíró 34, 54

István fia, máramarosi ispán 20

Orosz, viski polgár 57

Perényi 56

Pok nembeli Móric fia, máramarosi ispán 20

Úrmezei István fia 104

Úrmezei Szaniszló fia 104

Mikó, Hontpázmány nb. 21

Miskolc mezőváros 81

Misztice 56

Modor mezőváros 42

Mojs 30

Moldva 50

Moson megye 109

Munkács mezőváros 55, 56

Munkács vár 27, 51, 57
$\mathbf{N}$

Nagybánya 27, 69, 95

Nagy Iván 11

Nagymihályi család 56

Nagymuzsaj 111

Nagyszász 48

Nagyszombat város 7, 27, 42

Nagyszőllősi-hegység 56

Nagytécső ld. Técső

Nagyvárad ld. Várad

Ny

Nyaláb vár 25, 55, 56, 73

Nyágova 104, 105

Nyegre László 10

Nyeresznice 61

Nyitra város 70

Nyíres 51, 61

Nyírtelek 21

\section{O}

Odoardo Italicus (Manini), budai, dési, széki, máramarosi sókamaraispán, máramarosi ispán 26 , 65,66

Olt folyó 50

Opaviai hercegség 26

Orbán

huszti bíró, 81

Kowach, szőllősi bíró 82

Nagylucsei, kamaraispán 63

Ozorai Pipó 63

Óbuda 27, 28

Ökörmező 104, 105 
$\mathbf{R}$

Pap József 12

Radnót, Putnoki 67

Pape Manini, dési és széki sókamaraispán 65

Pál

Ártándi, királyi tanácsos, beregi és máramarosi ispán 28, 67

Baranyai Nagy (magnus) 93

Ilmeri, deák, huszti faktor 69, 95

Keselyűmezei 94

Kinizsi, sókamaraispán 26, 67, 74

Nagy (magnus), máramarosi ispán, alispán és rónaszéki várnagy 64

Rakasz 21

Rákóc 56

Remete 111, 112

Repina 105

Réthy Ferenc 9

Réthy Károly 15

Róma 110

Rónaszék 61, 62, 95

Rónaszék castellum 64, 68

\section{S}

Neste, técsői esküdt 80

Pape fia, máramarosi sókamaraispán 66

szigeti pap, Tamás deák fia 96

técsői plébános 23

Petrovay György 13

Pest város 7, 27

Petrov Elek 52

Péter

Aranyani, huszti plébános 97

Butkai, sókamaraispán 26

Csebi Pogány 104, 105

Csonka, deák, hosszúmezei polgár 99

Dési, máramarosi ispán 68

Dolhai, aulicus 41, 74, 83

Kisvárdai Aladár 105

Nyerges, szőlősi polgár 97

Odwarbyrow Miklós fia, Alsóapsai 68

Perényi 25

Szarvaszói Gerhes 53, 54

Szigeti, deák 95, 96

szigeti polgár 96

Pilis megye 24

Poroszló 66, 67

Pozsony város 7, 27, 42

Sarkad 55

Sárvár 77

Schmidt László 12

Simon

huszti plébános 72, 94

Kosorka 56

Simonczich Ince 9, 40, 44

Solymosi László 100

Sopron város 7, 27, 63

Sopron megye 19

Sóakna 62

Sugatag 61

Sydepataka 95

Syle Pencz, szigeti polgár 96

$\mathrm{Sz}$

Szabó Károly 11

Szabó Zoltán 13

Szakolca város 27

Szalacs 66, 70

Szalárd 66

Szaniszló, Úrmezei Szaniszló fia 104

Szaplonca 36, 53, 62, 78, 79, 84

Szarvaszó 36, 50, 53, 54, 61, 84

Szatmár megye 23, 24, 50 
Szatmár város 66, 70

Szádeczky Lajos 11

Szárazpatak 56

Szász, oláh vajda 24, 50

Szászfalu 56

Száva folyó 63

Szeged város 7, 27, 70, 71

Szentpéterszeg 66

Szepesség 55, 70

Szerbia 50

Szerednye mezőváros 56

Székesfehérvár város 7, 27

Széphegy 56

Sziget mezőváros 7, 11, 19, 21, 23, 24, $25,26,28,36,39,40,44,47,48,49$, $54,61,62,68,69,72,75,76,77,78$, $79,80,81,82,83,84,85,86,87,89$, $90,91,92,95,96,97,101,105,108$, 111,112

Szikszó mezőváros 67

Szilágy megye 24, 52

Szilágyi István 10, 12

Szlovákia 50

Szobránc mezőváros 56

Szolnok megye 24

Szolnok mezőváros 66, 70, 71

Szőllős város 20, 29, 31, 32, 34, 35, 36, $37,38,41,42,48,56,73,82,95$, 110,111

Sztankó, Bedőházi 53

Sztán, Péter fia 51

Sztropkó mezőváros 81, 83

Szukna 92

Szurdok 50

$\mathrm{T}$

Talaborfalva 23, 24, 61, 62

Talabor-patak 25, 62, 103

Tamás

deák, szigeti polgár 100
Imre fia (Emerici), huszti bíró 41, 80,81

Nyerges, hosszúmezei bíró 34, 92

Orsoly, szigeti polgár 96

Sebesi, rónaszéki rationalis 69

szabó, huszti polgár 98

Veresmarti László fia 104

Zay, técsői esküdt 80

Tekeháza 43, 56

Técső mezőváros 7, 15, 16, 23, 24, 25, $26,29,34,36,39,40,44,47,48,49$, $50,53,61,62,69,72,75,77,78,80$, $81,82,83,84,86,87,92,93,95$, $101,103,108,111$

Thalaborsowa 61

Thaly Kálmán 11

Thatul, Irholci 53

Tiszabecs $l d$. Becs

Tisza folyó 19, 23, 35, 55, 56, 61, 62, $63,66,70,95,103,110,111$

Tiszaluc $l d$. Luc

Tokaj 66, 70

Torda város 55, 59, 63, 70, 71

Tordai Balog Márton 9

Tótfalu 66

Tóth János 9, 15

Tóth Péter 16

Törcsvár 27

Tőketerebes 56

Túróc megye 55

$\mathrm{U}$

Uglya 61

Ugocsa megye 20, 21, 22, 23, 25, 31, $47,48,52,54,55,56$

Újhely 95

Újhelyi család 31

Ulászló

I., magyar király 42 
II., magyar király 26, 43, 44, 72, $73,74,82,96$

Ung megye 56

Ungvár mezőváros 56, 70

Úrmezei család 25, 94, 103, 105

Úrmező mezőváros 25, 61, 103, 104, $105,108,111$

\section{V}

Vasvár mezőváros 63

Vályi András 9

Váncsfalva 36

Várad város 66

Vári mezőváros 19

Veresmart 56, 61, 62, 104

Veréce 48

Verőce 56

Vincfalva 104

Visegrád város 27

Visk mezőváros 7, 14, 15, 21, 23, 24, $26,29,39,40,44,47,48,49,61$, $75,77,78,85,86,87,91,93,101$, 103,111

viski vár 21

Visó 52

Vízakna város 63

W

Wenzel Gusztáv 10, 12, 40, 52

\section{Z}

Zagyva folyó 63

Zavada 56

Zemplén megye 55, 111
Zs

\section{Zsigmond}

Csebi Pogány, sókamaraispán, máramarosi ispán 26, 28, 44, $64,69,97,105$

Csicseri, deák, rónaszéki jegyző 69

magyar király 25, 29, 40, 42, 49, $51,53,60,63,65,71,74,77$, $79,93,95,96,103$

Zsolna város 70

Zsófia, szigeti polgárnő 96 


\section{REZUMAT}

\section{DEZVOLTAREA ORAŞELOR ÎN MARAMUREŞUL MEDIEVAL}

Târgurile de coroană din Maramureş - Hust (Huszt), Sighet (Sziget), Teceu (Técső), Visc (Visk), Câmpulung (Hosszúmező) - au format un grup special în rândul celor mai multe sute de târguri (oppidum) din Regatul Maghiar medieval, deosebindu-se în mod evident de acestea şi din punct de vedere economic şi social.

Această situație a fost determinată de o serie de factori. Datorită veniturilor însemnate obținute din minele de sare, teritoriul a avut încă din secolul XIV o importanță aparte pentru conducătorii țării. Astfel, deja din timpul regilor Angevini puterea centrală le-a conferit celor cinci localități de oaspeți privilegii largi, care începând cu domnia regelui Sigismund de Luxemburg au fost confirmate sistematic și extinse treptat de toți regii și reginele care au urmat. Pe de altă parte, importanța teritoriului reiese și din faptul că încă de la începutul secolului XIV și până la sfârșitul Evului Mediu - exceptând o perioadă de câțiva ani din vremea domniei lui Sigismund, când au fost în posesia familiei Drágffy de Beltiug, - târgurile au constituit în permanență posesia regelui, iar, începând cu domnia regelui Mathia, cea a reginei. La începutul secolului XVI Cămara de sare din Maramureș și cele cinci târguri de aici au devenit posesiuni regale inalienabile, situație confirmată și de decretul din 1514. Cu toate că la sfârșitul Evului Mediu au fost ocazii când cămările au fost zălogite de către vistierie, stăpânirea regală, respectiv cea a reginei, s-a menținut în permanență. O situație diferită a avut cel de-al șaselea târg al comitatului, Urmezeu (Úrmező/Domneşti/Ruskje Pole), pe de-o parte datorită faptului că a luat naștere mai târziu, iar pe de altă parte deoarece până aproape de sfârșitul Evului Mediu a fost în stăpânirea familiei nobiliare de origine română, de Urmezeu (Úrmezei). Localitatea a devenit un târg clasic cu caracter agrar, tipul de târg cel mai des întâlnit pe teritoriul regatului.

Compoziția etnică colorată a comitatului a influențat de asemenea dezvoltarea târgurilor. În perioada timpurie acestea au fost populate de oaspeți maghiari și germani. Sașii, sosiți cel mai probabil dinspre comitatul Ugocsa, au reușit să se afirme doar în secolul XIV, asimilându-se treptat până în secolul XV. Rolul lor este semnificativ mai ales din punct de vedere al istoriei dreptului, ei aducând cu sine privilegiile orașului Nagyszőllős (Vynohradiv) din apropiere. Populația urbană nu a avut contacte importante cu populația ruteană din nord-estul comitatului, sau cel puțin izvoarele vremii nu vorbesc despre acestea. Mult mai strânsă a fost însă relația locuitorilor acestor târguri cu populația românească, coabitantă în multe 
locuri cu rutenii. Cu toate că românii nu s-au mutat în orașe, deja din secolul XIV orășenii au avut mai multe conflicte cu pătura superioară a acestei populații, membrii căreia s-au infiltrat treptat în rândurile nobilimii maghiare de rând. Pământul a constituit de fiecare dată cauza conflictelor, încălcarea reciprocă a hotarelor, pretinderea sau chiar ocuparea abuzivă a unor noi teritorii fiind faptele cele mai frecvente.

Extracția sării a avut în mod evident impactul cel mai adânc asupra dezvoltării orașelor din Maramureș. Interesul regalității față de aceste teritorii a vizat firește aceste mine de sare, mai precis veniturile importante realizate din sare. În urma unei reforme a cămărilor de sare, la sfârșitul secolului XIV a fost creată și în Maramureș o Cămară regală de sare, care a funcționat fără întrerupere în toată perioada tratată.

Organizarea economică a Cămării de sare a fost strâns legată de domeniul de la Hust. Centrul cămării s-a aflat la Hust, însă o cămară subordonată acesteia a funcționat și la Coștiui (Rónaszék). Funcția de comite al Cămării de sare a fost una importantă, ocupantul ei avea o jurisdicție extinsă asupra teritoriului, mai ales că acesta ocupa deseori în paralel și funcția de comite de Maramureș. Rolul lui a fost sporit și de faptul că în comitatele din nord-estul regatului au fost înființate mai multe cămări subordonate, care toate erau aprovizionate cu sare din Maramureș, conducătorii acestora fiind subordonați la rândul lor comitelui Cămării de sare din Maramureș. Acești comiți proveneau de regulă din rândul străinilor care aveau cunoștințe financiare și economice.

Cămara de sare a avut un impact important și asupra societății. În orașe au apărut tăietorii de sare, care s-au delimitat marcant de populația agrară și meșteșugărească a târgurilor. Deja din timpul regelui Sigismund de Luxemburg tăietorii de sare au format un corp juridic separat, în frunte cu judele lor propriu, nefiind supuși jurisdicției adunării generale a târgurilor. În procesele lor cu ceilalți locuitori juzii târgurilor erau asistați de juzii tăietorilor de sare. Au format o universitate (universitas), a cărei privilegii și îndatoriri au fost întărite în două rânduri pe parcursul secolului XV de către regalitate. Tăietorii de sare au încercat să-și impună interesele ca o comunitate, lucru dovedit și de faptul că la întrunirile lor numite tur-i au ajuns întotdeauna la consens în privința pretențiilor juridice și materiale care urmau să fie prezentate regalității. În funcție de situație, de exemplu în chestiunea remunerației, au apelat chiar la manifestări violente sau la greve. Spre deosebire de celelalte straturi sociale ale orașelor, ei primeau după munca prestată un salariu regulat și alte alocații: sare, alimente, îmbrăcăminte, etc., cele mai valoroase fiind cuburile de sare, pentru valorificarea cărora tăietorii au întreținut un comerț la scară redusă, activitate prin care își mai rotunjeau veniturile.

Alături de ei, în comerțul cu sare s-au implicat și alți angajați ai cămării, care primeau la rândul lor, regulat sau numai periodic, astfel de cuburi de sare. În general însă regalitatea acorda deseori sare atât nobililor, cât și bisericilor sau orașelor. Astfel, în comerțul cu sare au fost implicați de la tăietorii de sare până la comitele cămării mai multe categorii sociale. În regiune comerțul liber cu sare a fost permis practic pe tot parcursul Evului Mediu. 
Cămara a asigurat în același timp o sursă de venit și pentru alte categorii sociale. Personalul vaselor de transport ale sării, iobagii căruțași de sare, numărătorii cuburilor de sare extrase (máglás), mânuitorii mașinilor din ocne (gépelyes) sau diverșii meșteșugari și-au găsit cu toții de lucru pe lẩngă aceste saline. Printre angajații cei mai de seamă au fost acei literați, care au avut un anumit nivel de învățătură și erau familiarizați cu scrisul. În conducerea întregului sistem al cămărilor un rol important le-a revenit literaților, deseori străini, angajați drept administratori ai salinelor cămării (sótiszt). Aceștia, asemenea tăietorilor de sare, au fost locuitori ai târgurilor, cei mai mulți stabilindu-se la Hust și Sighet. Astfel, cu toată incertitudinea izvorâtă din numărul relativ restrâns al izvoarelor, putem afirma că în târgurile maramureșene proporția literaților a fost mult peste media celorlalte târguri ale regatului.

Alături de literați, printre locuitorii târgurilor erau în număr relativ mare și nobili. În primul rând în cele două târguri amintite anterior, dar mai ales la Sighet, procentajul locuitorilor cu titlu nobiliar a crescut în mod semnificativ până în secolul XVI. Altminteri, între membrii celor două categorii sociale existau multe întrepătrunderi, o parte semnificativă a nobililor fiind în același timp și literați, lucru explicat prin faptul că mulți dintre literați au fost înnobilați la turnura secolelor XV-XVI pentru serviciile depuse în administrația sării. Din punct de vedere economic elita acestor târguri o constituiau firește acești nobilii literați, care aveau posesiuni întinse, mai ales mori și posesiuni cu drepturi nobiliare în apropierea orașelor. Majoritatea posesiunilor erau în mâinile lor. În mod surprinzător și unic pentru tot teritoriul regatului însă, această elită nu și-a manifestat interesul spre pozițiile de conducere ale târgurilor. Lipsesc aproape cu desăvârșire datele care să ateste că ar fi fost juzi sau jurați în adunarea generală a orașelor, funcțiile acestea fiind ocupate de categoriile sociale obișnuite ale târgurilor.

În privința meșteșugarilor și a agricultorilor izvoarele păstrează informații sporadice, mai ales pentru primii. Pe baza acestora se pare că nivelul de dezvoltare al industriei manufacturiere din Maramureș nu a atins un nivel prea ridicat nici în privința diferențierii profesiilor și nici în ceea ce privește proporția meșteșugarilor. Pe baza unor izvoare din epoca premodernă poate doar Sighetul a constituit o excepție în acest sens. În privința populației agrare din Evul Mediu datele și mai puține sugerează că datorită factorilor geografico-economici creșterea animalelor a jucat rolul principal în subzistența ei.

Din punct de vedere juridic cele cinci târguri regale de coroană din Maramureș au făcut parte, în mod incontestabil, din categoria târgurilor. Cu toate că în secolul XIV apar de multe ori cu denumirea de villa și mai rar de civitas, în esență, atât mediul social înconjurător, cât și ele însele s-au considerat a fi oppidum, denumire care apare din ce în ce mai frecvent în documentele secolelor XV-XVI. Acest lucru se reflectă și în organizarea juridică interioară a acestora, fiecare având deja în secolul XV un sistem de autoguvernare internă, format din juzi și jurați cu atribuții extinse, similare altor târguri ale țării. O particularitate rară o constituie prezența în conducerea orașelor, alături de jude și jurați, a celor 24 sau 12 bătrâni, instituție împrumutată cel mai probabil din dreptul orașului Nagyszőllős, al cărui adunare generală a funcționat de altfel ca instanță de apel a târgurilor din Maramureș. 
Analizând dezvoltarea generală a celor cinci târguri regale de coroană din Maramureș, observăm că factorii determinanți obișnuiți ai dezvoltării orașelor lipsesc sau apar doar parțial. Spre exemplu, nu avem date despre dreptul acestor localități de a ține târguri anuale, cu toate că în Evul Mediu trebuiau să beneficieze de astfel de privilegiu. Un indicator important al dezvoltării orașelor în toată Europa medievală a fost stabilirea ordinelor mendicante în interiorul acestora, lucru ce nu este semnalat în Maramureș. A existat totuși o mănăstire, cea a paulinilor, aflată pe malul sudic al Tisei, însă nu au existat relații strânse între aceasta și locuitorii târgurilor. Orășenii nu s-au interesat în mod special nici de studiile universitare, cu toate că în perioada aceea studenți din alte părți ale regatului au frecventat deja în mod constant universitățile din Cracovia sau Viena.

Pe baza celor prezentate credem că dezvoltarea orașelor maramureșene a fost un proces oarecum ambiguu față de alte teritorii ale regatului. În mod incontestabil, motorul dezvoltării a fost mineritul sării și comerțul cu sare, ceilalți factori ai dezvoltării fiind prezenți doar sporadic. În ciuda acestora nu spunem că situația ar fi fost în defavoarea cetățenilor: sarea, ca cea mai importantă sursă de venit, le-a conferit acestora o subzistență sigură, Cămara de sare le-a favorizat afirmarea socială, iar statutul de posesiune regală inalienabilă le-a asigurat stabilitatea și previzibilitatea, factori care au conturat un drum unic de dezvoltare pentru târgurile regale de coroană din Maramureș și pentru locuitorii acestora.

Traducere: PAKÓ LÁSZLÓ Corectură: LIVIA ARDELEAN 


\section{ABSTRACT \\ URBAN DEVELOPMENT IN THE MEDIEVAL MÁRAMAROS}

The royal towns in Máramaros were a special type of market-towns type (oppida) in medieval Kingdom of Hungary. They differed clearly from the other several hundreds of Hungarian market-towns, if we look at their economic and social aspects.

There are many reasons for this. Because of the huge income from the salt mines in Máramaros, it was an important region for the king already from the beginning of the 14th century. This importance partly revealed itself in the extensive privileges that the royal authority conferred upon the inhabitants of the five hospes-colony even during the reign of the Anjous. Our kings and queens regularly reconfirmed and gradually strengthened these privileges.

The other sign of this importance is that, except for a few years during Sigismund's rule, when the region was in the family of Bélteleki's hands, these towns were permanently royal and from the age of Mathias, queenly estates. The salt chamber of Máramaros, with it's five market towns became indefeasible royal estates at the beginning of the 16th century, being ratified by a decretum in 1514 . During the end of Middle Ages we can observe that the treasury pawned a few times these chambers but the royal and queenly ownership is still a fact. This claim is not true, however, in the case of the county's sixth market town, Úrmezö, which was established later, and was possessed till almost the end of Middle Ages by a noble family of Romanian origin (Úrmezei). Úrmező became a traditional, agricultural market-town, the most common type in the country.

The development of these market-towns was also determined by the multicultural environment of the region. The early period saw Hungarian and German hospes-colonists populate the towns. The Saxon colonists, arrived probably from Ugocsa, gained importance in this respect only in 14th century and were gradually assimilated by the 15 th century. Their role is significant, however, in the legal history: they introduced the privileges of the nearby town Szőllős into their new homes.

The bourgeoise did not have significant connections with the Ruthenes, living in the northeastern part of the county's border, or at least this fact cannot be verified by the sources. They had more serious interactions with the various groups of Romanians, who were living outside the towns, among Ruthenes. The members of the Romanian elite were slowly assimilated into the ranks of Hungarian nobility. 
The town's inhabitants have had many conflicts with this assimilated group from early as the 14th century. The causes of these conflicts were always linked to the estates: they violated each other's borders or made claims for the other's estate, even using violence to achieve their goals.

Salt mining contributed the most directly and significantly to the town development of Máramaros. Royal authorities showed special interest in Máramaros thanks to the huge royal incomes from salt mining. After a general reform of the salt chambers in the end of 14th century, a royal salt chamber was established in Máramaros, which functioned constantly.

The economical organisation of the salt chamber was closely attached to the domain of Huszt. Huszt was the centre, but also had a subordinated chamber in Rónaszék. The position of salt chamber steward was very important because it had extensive jurisdiction in the region as the chamber steward was, in most cases, the steward of the whole Máramaros. A number of subordinated chambers were established in the northeastern counties of Hungary, which were supported with salt from Máramaros: this also added to the significance of this position. The salt chamber steward of Máramaros supervised the leaders of subordinated chambers. Many times foreigners held this title, because they were familiar with the finances and economical matters required for this office.

The Salt Chamber had a notable impact on society: salt cutters appeared in towns, which lived a separate life from the agricultural and industrial groups of market-towns. Salt mine workers were already a separate legal group in the age of Sigismund. They had their own judge, so they were not under the jurisdiction of market-town council.

Their issues related to town citizens had to be judged in conjunction with salt cutter judges. The salt cutters were in fact a universitas: their rights and obligations were summarized by the royal authority two times during the 15th century, in the form of privileges.

Salt cutters always acted as a whole to enforce their rights, as it is clearly shown by the fact that they had their own council, the so-called "tur". This council served as a place where agreement on how to enforce financial and legal rights, even against the royal authorities, (sometimes by using violence or strikes) could be made.

They received regular salary and other bonuses (salt, food, clothes etc.) and in this respect they differed from the traditional groups of market-town society, too. From these bonuses the most important was the salt as it could be used for trade and extra income. However, other intellectual and manual workers of the salt chamber also participated in salt trade, because they received regular or irregular salt supplies. Several groups of society were interested in salt trade, since royal authority often conferred salt supplies to nobles, clergymen and towns. Free trade with salt was permitted constantly during the Middle Ages in this region.

In addition, the Salt Chamber provided an income for other groups. From the crew of the ships carrying salt to the different groups of craftsmen and villains, there were various work-around possibilities to the chambers. 
Most significant were the intellectual functions, which required education and literacy. These litteratus-groups, mostly foreigners, were responsible for the economic issues of chamber organisation. Like the salt-cutters, they lived in markettowns, mostly in Huszt and Sziget.

Hence the number of litteratus-groups in these market-towns was reported to be higher than in any other parts of the country - however, this is only a rough estimate based on a few sources.

Beside the litteratus-groups, there are many nobles among the town's inhabitants. The two above-mentioned market-towns (but mainly Sziget), underwent, by the 16th century a remarkable nobilization. Moreover, the two groups overlapped one another: some nobles were also literates. It is not a coincidence, as many gained a nobility title for loyal services through the chambers, probably at the turn of 15th and 16th centuries. They were the economic elite of these market-towns and large estates belonged to them. They owned mainly mills and noble estates and most of the estates were their property.

It's surprising and at the same time unique that this elite was not interested in becoming members of the market-town council. We have almost no records showing that they were members of a council. On the contrary, traditional market-town groups became judges and jurymen.

We have data mostly on industrial, rather than agricultural groups of markettown society. According to the few available sources, the handicraft of Máramaros was in a state of moderate development and the craftsmen constituted only a small part of the society. The only exception was probably Sziget, in the early modern period. Even less sources tell us about the agricultural groups in the Middle Ages, but it can be easily noticed that extensive livestock farming held a capital importance for living, thanks to factors of economic geography.

In a legal aspect the crown towns in Máramaros were definitely market-towns. Although they were named many times in the 14th century as villa and sometimes civitas, these five towns were clearly of the oppidum-type. The name oppidum was becoming more and more frequent in sources from the $15^{\text {th }}$ and $16^{\text {th }}$ centuries. This reflects the changing legal circumstances: by the $15^{\text {th }}$ century, as a multi-potent municipal organization functioned in these market-towns. Based on its powers, this council resembled the other market-town councils of the country. A rare characteristic was, however, that besides the magistratus, 24 or 12 "elders" also participated in local government. This custom took its inspiration from Szőllös and these market-towns could appeal to the council of this town.

We get an unusual picture if we measure the general development of these five towns. The factors responsible for towns' development elsewhere were not, or were barely present in Máramaros. We do not have information for example about the right to hold a fair in these towns, even if we suppose they had one in the Middle Ages. Monasteries of the mendicant orders, an mark of the development factor in the Middle Ages, were not established. Although there was a Pauline monastery near the southern bank of Tisza, the town's inhabitants did not have a close connection with it. The bourgeoise weren't interested in University studies, whereas contemporary Hungarian students regularly visited universities of Krakkó and Bécs. 
It seems that the town development in Máramaros was somewhat unmatched. Salt mining and salt trade contributed mostly to the town development, and other factors were of less or no importance in this aspect. Still we cannot say that these circumstances were adverse for the development of the bourgeoisie. The salt as a source of income meant good living, the Chamber meant social mobility and the indefeasible royal estates ensured stability, which allowed a unique development for the bourgeoise of Máramaros.

Translation: TÖRŐ LÁSZLÓ DÁVID 
A "máramarosi koronavárosok", azaz Huszt, Visk, Técső, Hosszúmező és Sziget elidegeníthetetlen királyi birtok voltuknak köszönhetően egyedülálló helyet foglaltak el a középkori magyar városhálózatban. Ettől függetlenül azonban szigorúan véve mindegyikük egyszerú mezővárosnak számított csupán a korban, még ha az országban található többszáznyi oppidumtól különböztek is néhány fontos jellegzetességükben. A különbség legfőbb oka a sóbányászatban és -kereskedelemben játszott kiemelkedő szerepük volt, amely középkori és későbbi fejlődési lehetőségeiket több szempontból is befolyásolta. Jelen munka arra keresi a választ, hogy ez a sajátos helyzet milyen tényezők eredményeképpen alakult ki, illetve milyen nyomot hagyott társadalmi fejlódésükön, és hogyan befolyásolta gazdasági mozgásterüket.

ISBN 978-606-739-003-2

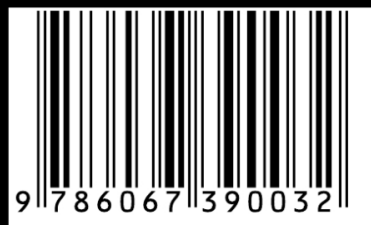

